\author{
Universidade de São Paulo \\ Faculdade de Filosofia, Letras e Ciências Humanas \\ Departamento de Filosofia \\ Programa de Pós-Graduação em Filosofia
}

Cauê Alves

\title{
A dimensão filosófica do trabalho de Mira Schendel
}

São Paulo

2010 
Cauê Alves

\section{A dimensão filosófica do trabalho de Mira Schendel}

Tese apresentada ao Programa de Pósgraduação em Filosofia do Departamento de Filosofia da Faculdade de Filosofia, Letras e Ciências Humanas da Universidade de São Paulo para obtenção do título de Doutor em Filosofia

Orientadora: PROF ${ }^{a}$. DR ${ }^{a}$. Marilena Chaui São Paulo 2010 
"Há metafísica a partir do momento em que, cessando de viver na evidência do objeto - seja o objeto sensorial ou o objeto da ciência -, apercebemos indissoluvelmente a subjetividade radical de toda nossa experiência e seu valor de verdade."

O Metafísico no homem Merleau-Ponty 
Para minha filha Mira 


\section{Agradecimentos}

À Marilena Chaui, pela paciência e generosidade de sempre indicar novos horizontes;

À banca de exame de qualificação, Sônia Salzstein e Lorenzo Mammì, pelas valiosas críticas e contribuições;

À Ada Schendel por abrir as portas de sua casa e me permitir pleno acesso aos arquivos de Mira Schendel;

À Lia pela compreensão de minha ausência e pela sua presença;

À Vera pela atenção e disponibilidade e ao Miguel, pelas conversas e pelo tempo que dedicou em discutir comigo a tese.

À Margarida, Rudy, Wanda e Apoena, que de longe acompanharam o trabalho e sempre me incentivaram mesmo na escolha dos caminhos mais tortuosos;

Ao Grupo de Estudos Espinosanos: estudos sobre o século XVII, pelas discussões e seminários sobre filosofia moderna e contemporânea;

Aos companheiros da Revista Número: Carla Zaccagnini, Fernanda Pitta, Guy Amado, José Augusto Ribeiro, Taisa Palhares e Thais Rivitti, assim como aos críticos Fernando Oliva e Tiago Mesquita; 
A todos os artistas com os quais dialoguei nos últimos anos e sobre os quais escrevi pequenos textos;

Aos colegas do curso Arte: história, crítica e curadoria da PUC-SP; do Bacharelado em Artes Visuais do Centro Universitário Belas Artes; da Faculdade de Comunicação da Faap e da Escola da Cidade;

Aos amigos Léo e Zé. E a Miriane pelos ensinamentos de psicologia. À Tânia pela ajuda nos cursos do CEUMA;

À professora Carmen Aranha, que me acolheu no MAC-USP durante a graduação;

À Raquel pela gentileza em realizar a versão em inglês do resumo da tese;

Aos funcionários do Departamento de Filosofia. 
Banca Examinadora 
Alves, Cauê [1977-]

A dimensão filosófica do trabalho de Mira Schendel - São Paulo (SP), 2010. 213f.

Tese (Doutorado - Programa de Pós-Graduação em Filosofia)

Orientador(a): Profa Dra Marilena Chaui

1. Arte 2. Linguagem 3. Corpo 4. Metafísica 5. Fenomenologia 


\section{Resumo}

ALVES, Cauê. A dimensão filosófica do trabalho de Mira Schendel São Paulo (SP), 2010. 213f. Tese (Doutorado) Faculdade de Filosofia, Letras e Ciências Humanas, Universidade de São Paulo, Departamento de Filosofia, São Paulo, 2010.

O presente trabalho visa problematizar e desenvolver questões referentes aos vínculos entre filosofia e arte, particularmente a partir do trabalho de Mira Schendel e do pensamento de Merleau-Ponty. Não se trata da filosofia como pensamento ilustrado pela obra e tampouco de uma mera demonstração de erudição. A pergunta sobre a dimensão filosófica do trabalho de Mira Schendel, artista com rara vocação para a filosofia, será abordada sob duas perspectivas: em primeiro lugar no sentido interno à obra de Schendel e, em segundo lugar, a partir das interlocuções que a artista estabeleceu com a obra de filósofos como Wittgestein, Sartre e, particularmente, com a fenomenologia, além de dialogar diretamente com pensadores como Hermann Schmitz, Vilém Flusser e Haroldo de Campos. Mira Schendel declarou diversas vezes sua admiração pelo pensamento do professor, filósofo e fenomenólogo Hermann Schmitz, da Universidade de Kiel, na Alemanha (que deu prosseguimento às pesquisas de Husserl). Esses dois eixos perpassam o conjunto da obra de Schendel, tornando possível trazer todo um percurso artístico para o debate.

A tese não deixa de lado as tensões próprias do pensamento, uma vez que a filosofia de Merleau-Ponty aponta para direções que nem sempre coincidem com o trabalho da artista. No conjunto do debate estético e filosófico nos importa sinalizar os conflitos teóricos entre o conceitualismo na arte e o pensamento de Merleau-Ponty para se pensar a relação entre arte e filosofia na obra de Mira Schendel.

Palavras-Chave:

Arte, linguagem, corpo, metafísica, fenomenologia 


\begin{abstract}
The aim of this work is to bring to light questions that compare philosophy and art, specifically focusing on the work of Mira Schendel and the school of thought of Merleau-Ponty. The aim is not to treat philosophy as an enlightened thought or a mere demonstration of knowledge but rather to take a look into the philosophical dimension of Mira Schendel's rare vocation for philosophy. This work will address two perspectives of this rare vocation. First it will take a look at the inner sense of Schendel's work and second, it will venture through the perspective of philosophical works such as Wittgenstein and Sartre, as well as place a specific focus on phenomenology. Beyond this there will also include discussions from thinkers such as Hermann Schmitz from the University of Kiel in Germany (who continued the research of Husserl.)These two themes run throughout the entire work of Mira Schendel thus making it possible to bring an entire artistic journey into light.

The thesis does not leave out the tension inherent in such thinking, due to the fact that the philosophy of Merleau-Ponty points to directions that do not always coincide with the artist's work. Throughout the aesthetic and philosophical debate, what really matters is to point out the theoretical conflicts between conceptualism in art and the thinking of Merleau-Ponty, while still bringing into account the philosophy in Mira Schendel's work.
\end{abstract}

Key-words:

Art, language, body, methaphysics, phenomenology 


\section{Sumário}

Apresentação...................................................... 14

I. Introdução: Fim da história da arte e indeterminação.............27

Moderno e contemporâneo.....................................28

A concepção de Merleau-Ponty..................................35

Arte conceitual e o fim da arte................................47

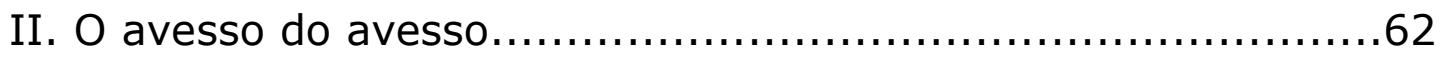

III. Arte e metafísica............................................. 78

IV. Os limites da linguagem e o fim da metafísica..................95

Diálogos com Vilém Flusser: Língua e realidade..............110

V. Corpo e corporeidade.......................................... 124

Diálogos livres com Hermann Schmitz.......................138

Conclusão........................................................ 149

Bibliografia.......................................................... 159

Reproduções de trabalhos de Mira Schendel.........................170 


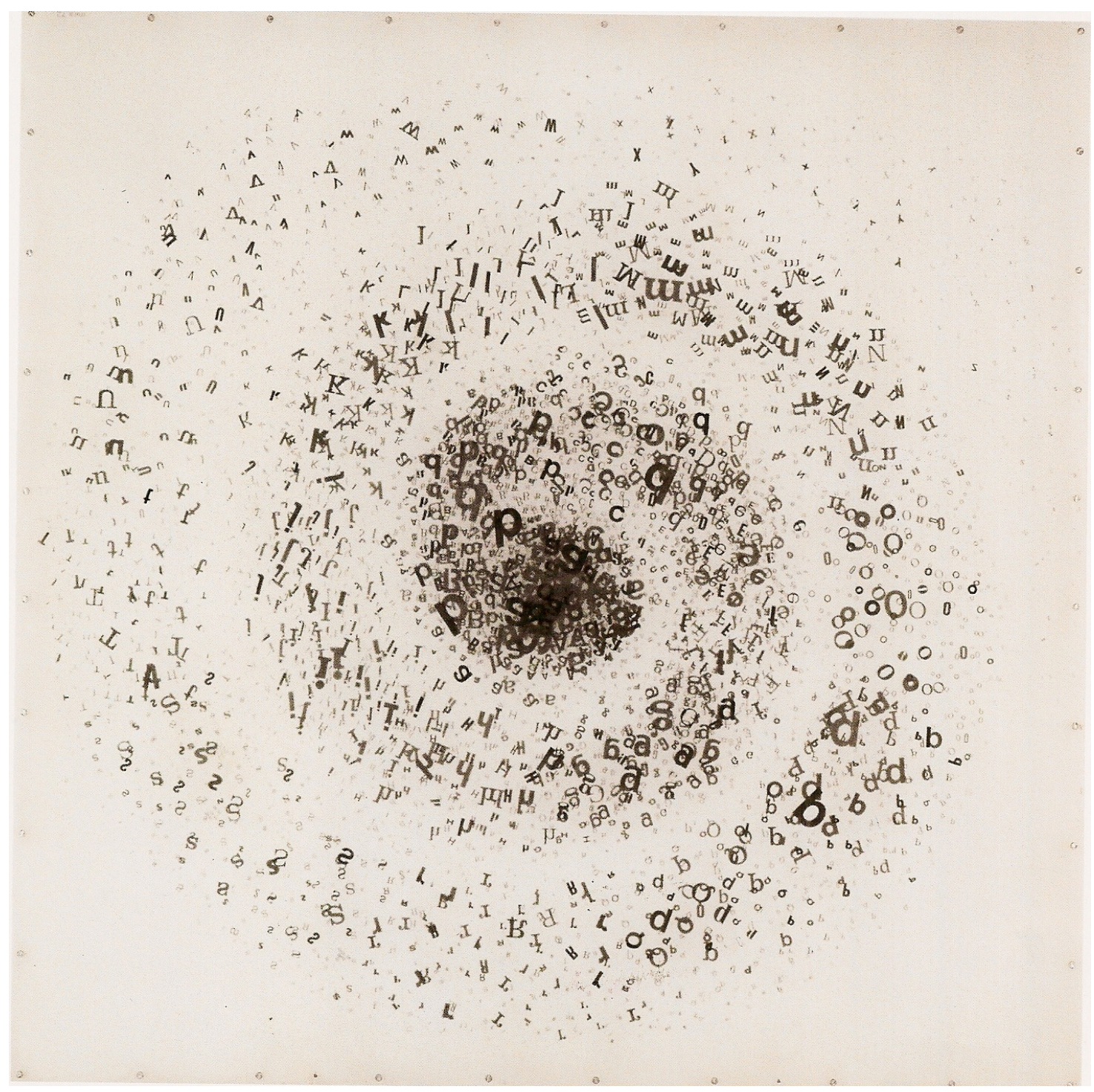

Sem Título, da série Objeto Gráfico, 1972

Letraset entre placas de acrílico transparente, $95 \mathrm{~cm} \times 95 \mathrm{~cm} \times 1 \mathrm{~cm}$ 


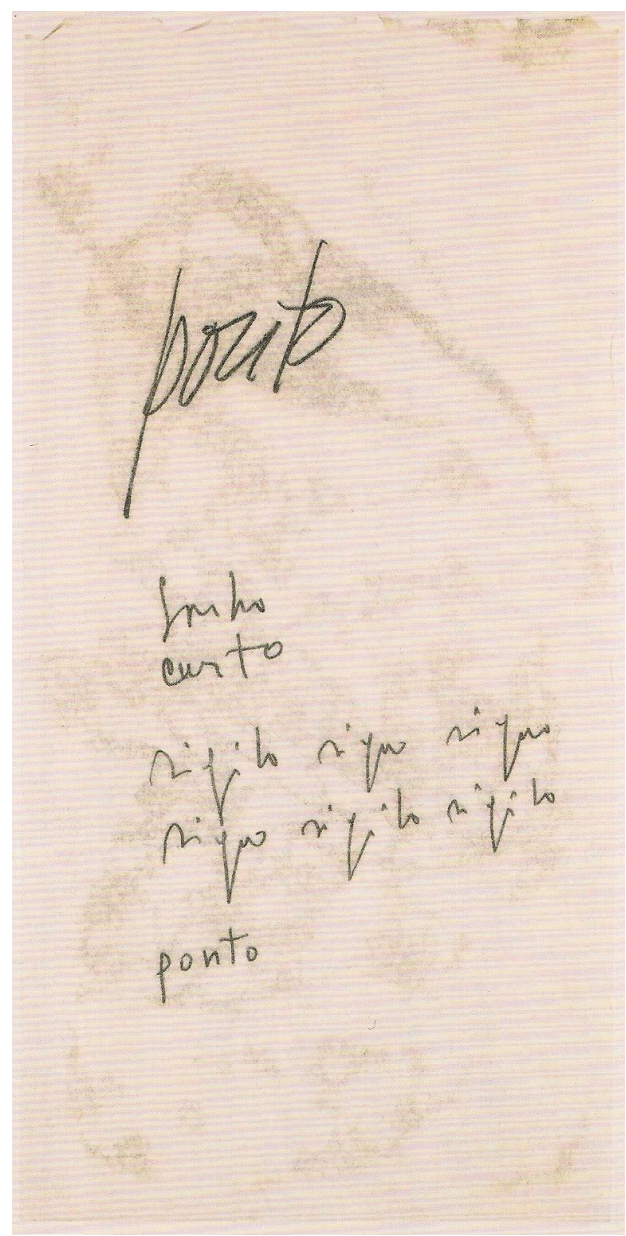

Sem título, 1964-65

Monotipia (óleo sobre papel-arroz), $47 \times 23 \mathrm{~cm}$ 


\section{Apresentação}

A filosofia de Merleau-Ponty esteve presente em parte significativa da arte brasileira do final dos anos de 1950 e início da década de 1960. Nos debates entre concretistas e neoconcretistas, argumentos de Merleau-Ponty, principalmente da Fenomenologia da Percepção, de 1945, foram relevantes para o desenvolvimento da arte construtiva no Brasil. No Manifesto Neoconcreto, de 1959, Merleau-Ponty é citado mais de uma vez e, a partir de sua crítica ao cientificismo da Gestalt, os neoconcretos combateram o mecanicismo e o objetivismo na arte concretista e recolocaram o problema da expressão. Mesmo como um momento bastante provisório na arte e, imerso num ambiente artístico bastante 
complexo e que jamais poderia ser reduzido a uma oposição entre paulistas e cariocas, o neoconcretismo é um dos marcos na percepção sobre a impossibilidade de realização completa da utopia racionalista e desenvolvimentista brasileira. $O$ ceticismo neoconcreto perante a racionalidade da forma rompeu com o cientificismo tecnológico e a ideologia impregnada nele, o que não é pouco, embora não tenha podido perceber as contribuições filosóficas da Gestalt. Apesar disso, artistas ligados ao neoconcretismo ${ }^{1}$, assim como uma artista ímpar como Mira Schendel (Zurique, Suíça, 1919 - São Paulo, Brasil, 1988) que traz questões diversas daquelas que estavam no horizonte das vanguardas construtivas no Brasil, recolocaram questões filosóficas na arte.

Antes mesmo da filosofia de Merleau-Ponty ter sido plenamente compreendida pelo nosso meio cultural ela parece ter sido descartada em nome de outra mais atual e que se adequaria à mentalidade ou as necessidades do presente. Roberto Schwarz, em seu ensaio "Nacional por subtração", sem desmerecer os teóricos da última leva, já nos alertava sobre os problemas da importação de escolas e teorias que são rapidamente descartadas em nome de outras terminologias mais recentes. Antes de se explorar o potencial de uma filosofia ou de um autor, a nossa vida cultural tende a abandonar referências importantes e a recomeçar o trabalho do zero. Prevalece assim certo desinteresse pelo trabalho da geração anterior, o que acaba impedindo a continuidade da reflexão:

\footnotetext{
"Nos vinte anos em que tenho dado aula de literatura assisti ao trânsito da crítica por impressionismo, historiografia positivista, new criticism americano,
}

\footnotetext{
1 Esse tema foi explorado por nós no primeiro capítulo da dissertação de mestrado $O$ pensamento em processo da obra de Hélio Oiticica. FFLCH-USP, 2004.
} 
estilística, marxismo, fenomenologia, estruturalismo, pósestruturalismo e agora teorias da recepção. A lista é impressionante e atesta o esforço de atualização e desprovincianização em nossa universidade. Mas é fácil observar que só raramente a passagem de uma escola a outra corresponde, como seria de esperar, ao esgotamento de um projeto; no geral ela se deve ao prestígio americano ou europeu da doutrina seguinte. ${ }^{\prime 2}$

Embora a questão central da tese, a saber, a pergunta sobre a dimensão filosófica de um trabalho de arte, tenha merecido poucos, mas bons estudos, a presente tese visa problematizar e desenvolver questões referentes aos vínculos entre filosofia e arte, particularmente a partir de Merleau-Ponty. Esta discussão terá como eixo central o trabalho de Mira Schendel, artista com rara vocação filosófica, que embora da mesma geração, não se ligou ao concretismo, ao neoconcretismo e nem a qualquer grupo organizado de artistas.

Nesse sentido, a obra de Mira Schendel contém, entre outras, duas dimensões que permitem recuperar questões referentes à relação entre arte e filosofia nos termos que propomos aqui. Não se trata da filosofia como pensamento ilustrado pela obra e tampouco de uma mera demonstração de erudição. Mas, em primeiro lugar, do ponto de vista interno à obra, Mira Schendel apresenta uma série de escritos e interrogações que constituem corpos, expressões de pensamento e indagações como, por exemplo, em uma determinada monotipia ela escreve: "ponto/ sonho curto/ sigilo [...] signo". Em outra desenha: "Zeit" [tempo], em diferentes caligrafias. É como se houvesse em seu trabalho uma "filosofia selvagem" transbordando, ou seja, um pensamento filosófico não elaborado filosoficamente e que surge do interior do trabalho de arte. Um segundo eixo que justifica discutir a relação entre arte e filosofia, tendo Mira Schendel como referência, diz

2 Schwarz, Roberto. Que horas São?: ensaios. São Paulo: Companhia das Letras, 1987. p. 30. 
respeito às interlocuções que ela estabeleceu com a obra de filósofos como Wittgestein, Sartre e, particularmente, com a fenomenologia, além de dialogar com pensadores como Vilém Flusser, Max Bense e Haroldo de Campos. Mira Schendel declarou diversas vezes sua admiração pelo pensamento do professor, filósofo e fenomenólogo Hermann Schmitz, da Universidade de Kiel, na Alemanha (que deu prosseguimento às pesquisas de Husserl), com quem manteve contato próximo e trocou correspondências. Mesmo que ela não tenha explicitado seu diálogo com a filosofia de Merleau-Ponty, as reflexões feitas ao logo da tese indicam que a relação entre o trabalho de Mira Schendel e Merleau-Ponty se mostrará frutífera. Esses dois eixos perpassam o conjunto da obra de Schendel, tornando possível trazer todo um percurso artístico para o debate entre filosofia e arte.

Sendo o conceito matéria-prima da filosofia, nos vimos obrigado a investigar o conceitualismo na arte, tendência que no limite colocaria a história da arte diante de seu fim. Como já se tentou aproximar a obra de Mira Schendel das vertentes conceituais $^{3}$ torna-se relevante a investigação das evidentes distâncias. Essas questões sobre o fim da arte nos permitirão também traçar relações com a obra de Merleau-Ponty e nos fazer perceber até que ponto sua filosofia nos ajuda na discussão da arte contemporânea. A partir do que podemos compreender como uma filosofia da história elaborada por Merleau-Ponty, e de sua noção de instituição, pretendemos construir uma resposta para a noção de fim da arte e da história da arte de derivação hegeliana.

As questões do fim da história da arte perpassam toda a arte contemporânea, uma vez que apontariam para a multiplicidade,

3 Um exemplo da tentativa de aproximação da obra de Schendel do conceitualismo pôde ser confirmado com a presença de um caderno de Mira Schendel na mostra "Arte Conceitual e Conceitualismos", no Centro Cultural Fiesp/ Galeria do Sesi, em São Paulo, entre junho e agosto de 2000. 
heterogeneidade e abrem diversas possibilidades de trabalhos e meios. As discussões de uma artista como Mira Schendel podem se ampliar se vistas a partir dessa abordagem. No limite, vamos investigar como se posiciona sua obra na medida em que ela se dirige para um alto grau de liberdade e se abre para as múltiplas possibilidades que talvez decorram da noção de fim da história da arte no sentido da quebra de uma história contínua e linear. Isso sem deixar de lado as tensões próprias do pensamento, uma vez que a filosofia de Merleau-Ponty aponta para outra direção, para qual deslocaremos em alguns momentos o foco de análise do trabalho de Mira Schendel. No conjunto do debate estético e filosófico nos importa sinalizar os conflitos teóricos para se pensar a relação entre arte e filosofia tendo como referência a obra de Schendel.

Investigaremos, no primeiro capítulo, a recorrência com que a noção hegeliana de fim da arte e fim das narrativas da história da arte aparece na segunda metade do século XX, assim como a ideia de fim da metafísica ${ }^{4}$ e dos limites da linguagem para sua elaboração. Em autores como Arthur Danto, Ferreira Gullar, Giulio Carlo Argan e Hans Belting, a noção de fim da arte é elaborada em sentidos diferentes e com intenções diversas. Nessa parte, pretendemos cotejar a argumentação de alguns desses autores e de artistas abordados por eles. A crítica de Merleau-Ponty à noção de história hegeliana, e o modo como podemos extrair de obra do filósofo francês uma discussão sobre a natureza filosófica da arte, servirá de contraponto à noção de fim da história da arte.

A partir de estudos dos últimos textos de Merleau-Ponty, particularmente de alguns cursos ministrados pelo filósofo nos anos de 1950 ( A instituição) e de O visível e o invisível, pretendemos, a

\footnotetext{
${ }^{4}$ A ideia de fim da metafísica foi elaborada pela filosofia analítica do início do século $X X$, particularmente por Ludwig Wittgenstein.
} 
seguir, nos aproximar da ontologia madura de Merleau-Ponty e de seu método indireto. A ontologia indireta de Merleau-Ponty, aquela que está pressuposta e que vive clandestinamente nas artes e na ciência, será um fértil campo para a compreensão do trabalho de Mira Schendel. Desenvolveremos o tema a partir da noção de história da arte presente nos textos do filósofo e da noção de trabalho de arte como historicidade viva, aquela que pode sempre possibilitar uma renovada e próxima experiência, um interminável recomeço. Como o que um trabalho de arte diz e o modo como o faz não pré-existem a ele mesmo, ou seja, como ele torna presente significações em vez de simplesmente traduzi-las para um novo suporte ou matéria - conseguindo ir além da sua materialidade, do visível e do sensível -, ele jamais poderá ser reduzido a um instrumento. A arte possui o que Merleau-Ponty costuma chamar de fecundidade ou pregnância, ela tem a capacidade de dar origem ao novo, de propiciar algo que ela não previu, de instigar o outro, o futuro, além de nos fazer rever o passado. Retomar o passado, seja por ruptura ou continuidade, abrir-se para o que ainda virá, talvez fundando uma nova tradição, para ser retomada, de um modo jamais pensado, é algo próprio da arte. É nesse sentido que se diz que o trabalho de arte é instituinte, porque ele não se contenta com o já instituído, mas institui outras significações até então inéditas. Por isso, a noção de instituição ${ }^{5}$, presente nos últimos textos do filósofo, será útil para compreendermos o modo como poderíamos derivar de sua filosofia uma espécie de "teoria da história da arte".

5 A noção de instituição para Merleau-Ponty tem um sentido amplo. Ela é empregada não apenas às obras de arte e de pensamento, mas também como acontecimentos matrizes na história, na vida pública, na vida privada (o amor) e na natureza, tanto para acontecimentos na vida dos animais como na nossa vida (puberdade).

5 Merleau-Ponty, M. "L'institution", in: Resume de Cours, Collège de France 1952-1960. Paris: Galimard, 1968, p. 61. 
Ao longo dos capítulos seguintes da tese iremos reencontrar de modo oblíquo essas questões no trabalho de Mira Schendel. Trataremos de investigar a sua proximidade e distância em relação às questões filosóficas. A partir de uma pesquisa sistemática realizada nos arquivos da artista (cartas, textos, depoimentos e diários) e também em sua produção visual (pinturas, monotipias, trabalhos tridimensionais), pretendemos examinar a dimensão reflexiva de sua obra. A artista estabeleceu uma singular relação com o pensamento filosófico e, particularmente, a filosofia de Merleau-Ponty parece dialogar com muitas das noções elaboradas em seu trabalho, como as de corporeidade, linguagem e tempo. Durante a pesquisa iremos recorrer também algumas das principais interpretações críticas de sua obra, bem como aos autores com os quais ela manteve contato. O modo como a artista chega ao limite da linguagem e elabora uma noção no limiar do fim da metafísica irá também nos interessar.

O segundo capítulo irá reabrir a discussão acerca de seus papeis - em especial de suas monotipias das décadas de 1960 e 1970 -, da noção de temporalidade e espacialidade presente neles, de fim da metafísica e também da metafísica que está silenciosamente pressuposta na arte. As Droguinhas, que no catálogo da $8^{a}$ Bienal de São Paulo, de 1965, foram denominadas de Droguinhas Fenomenológicas, e os Trenzinhos serão fundamentais na compreensão da dimensão filosófica do trabalho de Schendel. Não se trata da metafísica tradicional da essência e da aparência, mas a que fundamenta a tentativa de superação do subjetivo e objetivo como alternativas clássicas. Nesse sentido, o pensamento de Merleau-Ponty será de extrema relevância.

No terceiro capítulo, trataremos da relação de Schendel com a pintura metafísica italiana, principalmente nos anos de 1950 e de certa metafísica que podemos vislumbrar em seu trabalho. A partir 
da compreensão da biografia inicial da artista, assim como da relação entre vida e obra tal como Merleau-Ponty a elaborou em $A$ dúvida de Cézanne, poderemos nos aproximar da compreensão do vinculo entre necessidade e liberdade.

Em seguida partiremos do trabalho de Mira Schendel para investigarmos, no quarto capítulo, as relações entre linguagem e pensamento, bem como as concepções filosóficas de linguagem com as quais seus Cadernos de 1970 e 1971 dialogam. A linguagem, tal como Wittgenstein a pressupõe no Tractatus LógicoPhilosophicus, citada pela artista, irá se distinguir das investigações que Merleau-Ponty faz dela. Os usos que Schendel faz das letras e palavras em seu trabalho serão compreendidos tanto como linguagem originária e gesto corporal, como também - no caso específico de letras adesivas e nos Datiloscritos de 1973 - de um fecundo tratamento gráfico. Verificamos também até que ponto as teorias de um de seus principais interlocutores no campo da filosofia, Vilém Flusser, podem ser aproximadas de sua obra.

No quinto capítulo desenvolvemos o estudo sobre os trabalhos mais explicitamente tridimensionais e leves da década de 1960 e 1970 feitos por Mira Schendel com papel e acrílico. Iremos abordar a noção de corpo no pensamento de Hermann Schmitz, assim como nos Objetos Gráficos, nos Discos, Toquinhos. Neles, por mais que tendam à desmaterialização, irá se desenvolver as noções de corporeidade, de espacialidade e transparência bastante particulares. Pretendemos ainda abordar Ondas paradas de probabilidade, de 1969, que como a própria artista o definiu em suas anotações, lida com a "visibilidade do invisível". Algumas das reflexões presentes no livro póstumo de Merleau-Ponty, $O$ visível e o invisível, enriquecerá a discussão de seu trabalho. Pretendemos ainda, a partir desse livro e das citações que a artista faz de Sartre em relação à objetivação do outro, discutir brevemente as 
diferenças na concepção do outro para ambos os filósofos. Mira Schendel, assim como Merleau-Ponty, irá negar a idéia de redução do outro a uma coisa. No trabalho da artista também estará presente o respeito ao outro e essa recusa de tratá-lo como mero objeto.

Se o percurso traçado brevemente aqui parece um tanto elíptico e às vezes espiralado, vale lembrar que a forma da elipse foi bastante usada pela a artista e que sua trajetória também segue num ritmo cíclico e espiralado, com avanços, recuos e retomadas constantes.

As análises que Merleau-Ponty faz da historicidade da obra de arte e de pensamento serão válidas também para pensarmos a obra de Mira Schendel, mesmo que não tenhamos encontrado em seus arquivos referências explícitas ao filósofo.

A noção de instituição, não sendo uma ideia, nem um conceito, mas uma prática, um acontecimento, nos permitirá refletir sobre a obra de Mira Schendel como uma matriz que pede uma sequência temporal. Cada momento de sua trajetória é dotado de sentidos que irão gerar um futuro e negar a concepção mecanicista de história. É a noção de instituição que permitirá a abertura de um campo de experiências que se interligam. E cada uma das experiências, dotada de sentido e dando sentido à experiência seguinte, formará uma sequência, uma história.

"Entende-se aqui por instituição aqueles acontecimentos de uma experiência que a dotam de dimensões duráveis, com relação às quais toda uma série de outras experiências terão sentido, formarão uma sequência pensável ou uma história. Ou ainda os acontecimentos que depositam um sentido em mim, não a título de sobrevivência e de resíduo, mas como apelo a uma sequência, exigência de um porvir."

\footnotetext{
${ }^{6}$ Idem, ibidem.
} 
Será também a noção de instituição ${ }^{7}$, tal como formulou Merleau-Ponty, que irá propiciar a compreensão do artista não como aquele sujeito que constitui o mundo e dá sentido a ele, mas como um sujeito cuja ação pode ser instituinte ${ }^{8}$ no sentido em que abre um acontecimento que está por vir e assim possibilita uma série de outras experiências que podem formar uma história. Ele retoma os sentidos instituídos de um trabalho já feitos para reinventá-lo, pensar a partir dele.

Algumas considerações sobre o nosso método de pesquisa poderão ser úteis ao leitor. Foram consultados prioritariamente os arquivos inéditos da artista que pertencem a sua filha Ada Schendel. A questão que tivemos que enfrentar é sobre qual o estatuto dos textos e notas escritos por Mira Schendel. Como lidar com fragmentos dispersos de um pensamento em processo e que não teve a intenção primordial de se tornar público? Como confrontar a disparidade do material de seu arquivo como cartas destinadas a um interlocutor determinado, diários entrecortados por consultas ao oráculo chinês I Ching seguida da interpretação da artista, com questões que vão do âmbito privado e amoroso até tomadas de posições filosóficas? Em seus escritos parece não

\footnotetext{
7 A noção de instituição para Merleau-Ponty tem um sentido amplo. Ela é empregada não apenas às obras de arte e de pensamento, mas também como acontecimentos matrizes na história, na vida pública, na vida privada (o amor) e na natureza, tanto para acontecimentos na vida dos animais como na nossa vida (puberdade).

${ }^{8}$ Vale lembrar que a noção de instituição de Merleau-Ponty não possui qualquer relação com a "Teoria institucional da arte" tal como a formulada, por exemplo, por George Dickie em que uma obra de arte é definida como um artefato cujo valor lhe é conferido por alguma pessoa ou pessoas agindo em nome de alguma instituição social, o mundo da arte. Ou seja, os experts seriam os responsáveis por definir arbitrariamente o que é ou não arte, independentemente da intenção de seu autor. Cf. Dickie, G. Art and the Aesthetics: An Institutional Analysis. Ithaca, NY: Cornell University Press, 1974.
} 
existir qualquer oposição entre suas notas mais íntimas e sua pesquisa em arte.

Há nesse material um inacabamento que pode nos revelar os próprios sentidos se fazendo e surgindo para a artista. São esboços sem a pretensão de se tornarem obras, são indagações de um fazer solitário que em alguns momentos se transformam em diálogos por meio de cartas. Nesse sentido, podemos dizer que há mais lacunas na dimensão filosófica do trabalho de Mira Schendel do que pilares, assim como há mais questões do que respostas. Por isso, tomamos certas posições frente ao polimorfismo das obras e documentos consultados. Trata-se de uma leitura que exigiu escolhas que por vezes poderiam soar arbitrárias, mas que foram refletidas e visaram desenvolver o tema central da tese. Trata-se de um diálogo com Mira Schendel e certas referências filosóficas, o que nos permitiu cotejar autores dissonantes como Wittgenstein, Flusser, Merleau-Ponty, Sartre e Hermann Schmitz, ou seja, uma heterogeneidade de posições que são investigadas a fim de iluminar o trabalho de Mira Schendel. Não pretendemos em nenhum momento esgotar o tema, mas sim lançar luz num campo ainda pouco explorado tanto pela filosofia, como pela historia e crítica de arte.

O nosso recorte de obras e textos priorizou aqueles que nos permitem explorar os vínculos entre fenomenologia e arte, sempre aceitando as ambiguidades e diferenças entre as posições de Mira Schendel e a dos filósofos. Sabendo da importância de MerleauPonty no debate cultural brasileiro desde o final dos anos de 1950, nos interessou particularmente o fato de que com toda evidência a artista não faz referência direta a Merleau-Ponty, talvez porque tenha se aproximado de outra corrente fenomenológica e, no entanto, o trabalho de Mira Schendel ilumina, especialmente no debate brasileiro, certas questões de Merleau-Ponty que talvez 
autores declaradamente próximos ao filósofo francês, como os artistas ligados ao neoconcretismo, não explicitam até esse ponto. De fato, tendo contato direto ou não com a filosofia de MerleauPonty sua obra nos ajuda a entender o trabalho da artista, assim como Mira Schendel ilumina muitas das formulações do filósofo. Há algo em ambos que nos permite vislumbrar certas dimensões filosóficas da arte, é o que iremos desenvolver ao longo da tese. 


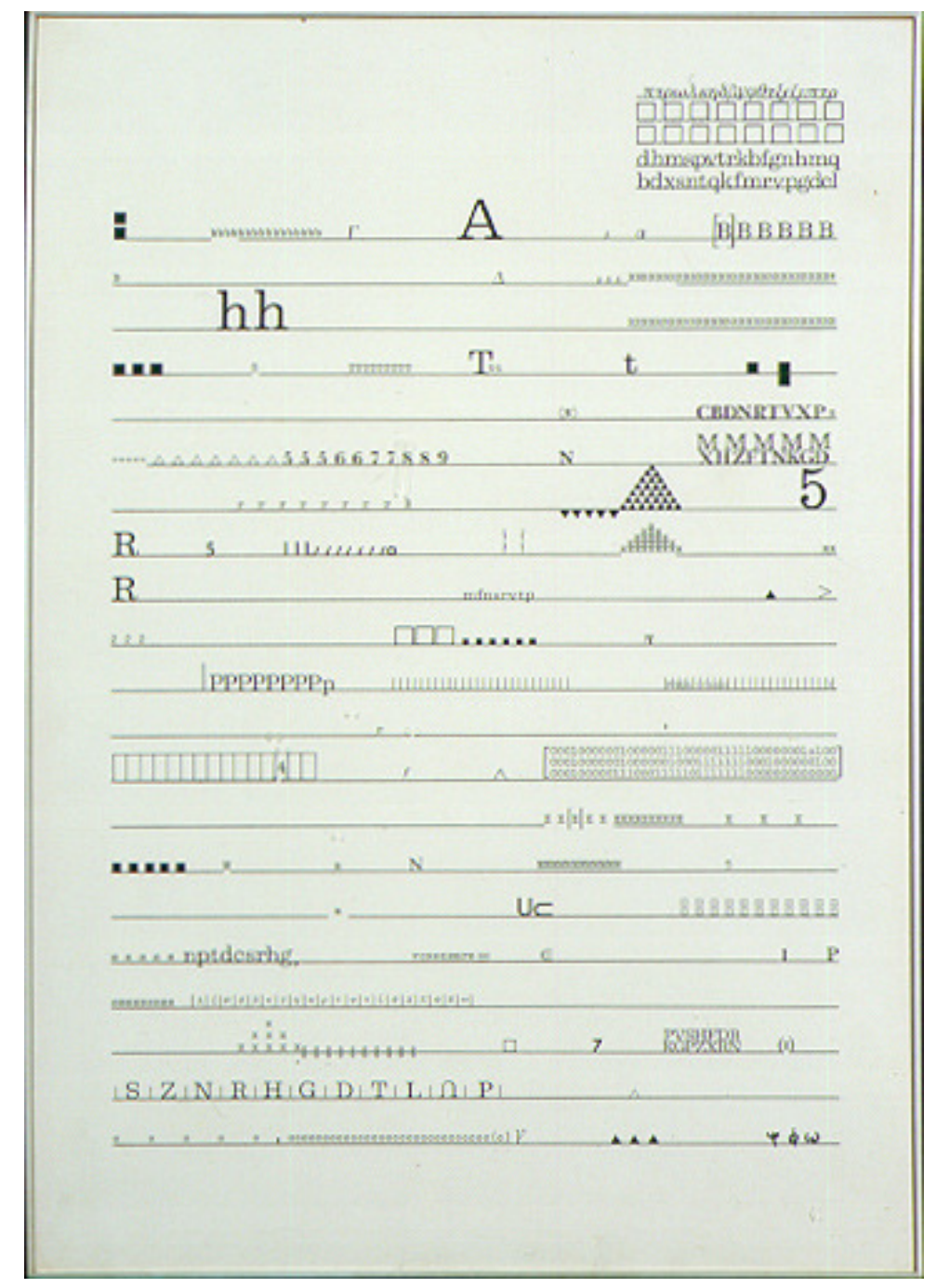

Sem título [datiloscrito], 1974

Datilografia, naquim, letraset e caneta hidrocolor sobre papel, $47,1 \times 32,8 \mathrm{~cm}$ 


\section{Introdução: Fim da história da arte e indeterminação}

Nas discussões realizadas nos final dos anos de 1990 acerca da noção de fim da história da arte, será importante destacar, uma vez acabada a idéia de progressão rumo a um sentido definido, a indeterminação do trabalho de arte, bastante presente na obra de Mira Schendel. A relação entre contingência e necessidade em seu trabalho poderá ser pensada tendo como pano de fundo certa discussão sobre teoria da história da arte. Para isso, iremos introduzir a questão do fim da arte tal como Arthur Danto a formulou. 


\section{Moderno e contemporâneo}

Definir o que seja arte moderna e suas diferenças em relação à arte contemporânea, que teria posto fim à história da arte, não é tarefa simples. Moderno não é apenas uma noção que diz respeito ao tempo e uma época histórica, assim como arte contemporânea não é apenas a arte moderna feita atualmente pelos nossos contemporâneos. A noção de arte moderna também diz respeito a um estilo, ou vários estilos, uma vez que nem tudo o que foi produzido entre o último terço do século XIX até mais ou menos a década de 60 do século XX é moderno. A arte moderna, mesmo que sob determinada perspectiva possa ser vista como continuidade da arte que a antecede, se colocou em franco embate com a arte acadêmica e oficial dos salões que, mesmo assim, continuou sendo produzida ao longo dos séculos XIX e XX.

Segundo Arthur Danto, "a história da arte evoluiu internamente, a contemporânea passou a significar uma arte produzida dentro de certa estrutura de produção jamais vista antes em toda a história da arte ${ }^{\prime \prime}$. Essa estrutura envolve um enorme circuito de arte com apoio institucional e de mercado nunca vistos na história em tal proporção antes da arte pop."Da mesma forma que o 'moderno' veio a denotar um estilo e mesmo um período, e não apenas arte recente, 'contemporâneo' passou a designar algo mais do que simplesmente a arte do momento presente. ${ }^{\prime 10}$ Segundo o filósofo e crítico americano, a arte contemporânea "designa menos um período do que o que acontece depois que não há mais períodos em alguma narrativa mestra da arte, e menos um estilo de fazer arte do que um estilo de usar estilos" ${ }^{11}$. Para Danto,

9 Danto, A. Após o fim da arte: A arte contemporânea e os limites da história. São Paulo: Odysseus Editora, 2006 [1997], p. 12.

${ }^{10}$ Idem, ibidem, p. 12-13.

${ }^{11}$ Idem, ibidem, p. 13. 
mas também para a maioria dos artistas atuais, há uma distinção precisa entre "moderno" e "contemporâneo". Este último se caracterizaria por uma espécie de "desordem informativa", de "entropia estética" e de total liberdade, onde tudo está permitido uma vez que não há mais limites históricos e tampouco uma clara oposição entre arte e não-arte. Trata-se do sentimento de que não há uma direção ou traço único que defina o período.

Ponto central na argumentação de Danto é a discussão do trabalho de Andy Warhol, a Brillo Box, de 1964, uma caixa de sabão em pó que, embora feita de madeira e impressa em silk screen, visualmente não se distingue de qualquer outra que esteja na prateleira de um supermercado. A partir desse trabalho, já não há mais nada que permita a distinção entre um objeto mundano qualquer de uma obra de arte. Não haveria limites entre arte e não-arte, ou melhor, essa definição deixa de estar no campo da percepção sensível e se desloca para o pensamento e para a narrativa da história da arte.

Ainda segundo Danto, para Andy Warhol sequer haveria a necessidade de um artista encontrar um estilo próprio, uma espécie de sistema de equivalências, um modo pelo qual o artista não tem tanto controle, mas que é reconhecível pelos outros. Para Warhol, um artista pode produzir num momento obras pop, em outro expressionista e na semana seguinte geométricas. Isso seria indício da liberdade total da arte contemporânea.

Para Lorenzo Mammì, ao contrário, a crise da noção de estilo individual, em vez de levar a uma maior liberdade, indica uma maior rigidez.

\footnotetext{
"Mesmo dentro da mesma personalidade, não podemos deixar de notar que o maior dos artistas modernos, Picasso, experimentou uma variedade enorme de estilos conflitantes, às vezes dentro de uma mesma obra. E que, em geral, quase todos os artistas do modernismo mostraram ao longo de sua obra uma variedade de
} 
recursos muito maior do que Andy Warhol, que no entanto, segundo Danto, seria o iniciador do trânsito livre entre os estilos." 12

O que parece substituir a noção de estilo na arte contemporânea, uma vez que o processo é cada vez mais valorizado, é a reiteração de certos gestos e procedimentos técnicos (o silk-screen de Warhol) que acabam ocupando o lugar do estilo. É como se o estilo se tornasse um procedimento, um modo de representar ou apresentar o trabalho, algo de que o artista tem todo o conhecimento e que, portanto, não será mais "o emblema de uma maneira de habitar o mundo"13. No caso de Warhol, tudo se passa como se a pintura já existisse antes mesmo dela ser pintada. A isso se acrescenta o ritmo acelerado com que surgem novos trabalhos sem que eles tenham a possibilidade ou intenção de instituir um estilo novo. Esses mesmos trabalhos são rapidamente descartados para dar lugar a novos.

Seria justamente isso que impossibilitaria, segundo Hans Belting, um modelo de história da arte que se funde no estilo de uma época e também na lógica interna da arte. É isso que proporcionaria uma dissolução de uma unidade interna da história da arte ou de uma narrativa da arte, ao menos de uma história universal da arte.

O principal alvo das críticas de Danto é a narrativa modernista de Clement Grenberg ${ }^{14}$, que buscou uma definição da essência do modernismo a partir de uma ideia de pureza e de autoconsciência da pintura moderna em direção à sua planaridade. Segundo Danto, com a ausência de uma linha narrativa única, que

\footnotetext{
${ }^{12}$ Mammì, Lorenzo. "Mortes recentes da arte". Novos Estudos, n 60. São Paulo: CEBRAP, Julho de 2001, p. 81.

13 Merleau-Ponty, M. "A linguagem indireta e as vozes do silêncio", Textos Escolhidos, São Paulo: Abril Cultural, 1975, p. 342.

${ }^{14}$ Greenberg, Clement. "Pintura Modernista". in: Ferreira, Glória e Cotrin, Cecília. (Org.) Clement Greenberg e o debate crítico. Rio de Janeiro: Funarte e Jorge Zahar, 1997.
} 
deixaria de fora momentos importantes da arte, como Greenberg havia feito com o surrealismo, a nossa passa a ser uma época de grandes possibilidades experimentais. $O$ fim de qualquer narrativa é o que marca o fim da história da arte e, segundo o autor, baseado em Hans Belting ${ }^{15}$, do mesmo modo que existe arte antes da era da arte (que se inicia no Renascimento) continuará existindo arte após o fim da arte. Trata-se do fim de uma história da arte linear ou, como elabora Belting: "do fim de determinado artefato, chamado história da arte, no sentido do fim de regras do jogo" ${ }^{16}$, mesmo que de outra maneira a história prossiga. Deixa de existir uma história da arte contada a partir de estilos ou uma história da arte distinta da história da cultura. Assim, ao mesmo tempo em que há o fim da vanguarda, deixa de haver alguma limitação sobre o modo como o trabalho de arte pode se formar. Passou a ser cada vez mais recorrente a noção de apropriação de outras imagens, onde obviamente a noção de um estilo uniforme não é mais relevante.

Belting, e principalmente Danto (aqui não nos interessa distinguir exatamente esses dois pensadores) se valem da noção hegeliana de fim da arte "como tomada de consciência da verdadeira natureza filosófica da arte ${ }^{\prime 17}$. Para esses autores, se o Espírito em Hegel se desenvolve em três etapas, da religião em direção à arte e desta em direção à filosofia, a nossa época marca justamente a perda da importância da arte para a pura reflexão, o puro pensamento. A arte deixa de ser para Hegel a manifestação do Espírito Absoluto tal como fora na Grécia antiga. Danto ${ }^{18}$ faz em

\footnotetext{
15 Belting, Hans. O fim da história da arte: uma revisão dez anos depois. São Paulo: Cosac Naify, 2006. [1995]

${ }^{16}$ Idem, ibidem, p. 9.

17 Danto, A. Após o fim da arte: A arte contemporânea e os limites da história. op. cit., p. 34.

${ }^{18}$ Idem, ibidem, p. 35.
} 
seu livro referência a essa questão que fica bem explicitada quando o filósofo alemão escreve:

\begin{abstract}
"Em todas estas relações a arte é e permanecerá para nós, do ponto de vista de sua designação suprema, algo do passado. Com isso, ela também perdeu para nós a autêntica verdade e vitalidade e está relegada à nossa representação, o que torna impossível que ela afirme sua antiga necessidade na realidade efetiva e que ocupe seu lugar superior. Hoje, além da fruição imediata, as obras de arte também suscitam em nós o juízo, na medida em que submetemos à nossa consideração pensante 0 conteúdo e o meio de exposição da obra de arte, bem como a adequação e a inadequação de ambos. A ciência [filosofia] da arte é, pois, em nossa época muito mais necessária do que em épocas na qual a arte por si só, enquanto arte, proporcionava plena satisfação. A arte nos convida a contemplá-la por meio do pensamento e, na verdade, não para que possa retomar seu antigo lugar, mas para que seja conhecido cientificamente [filosoficamente] o que é arte. ${ }^{19}$
\end{abstract}

A arte, tendo se tornado auto-refletiva, desde a arte moderna, a "Era dos Manifestos", passou a trazer para dentro de si o pensamento filosófico. A predição de Hegel seria confirmada assim, segundo Danto, pela própria história da arte que a sucedeu. A narrativa da arte chega ao fim quando a natureza filosófica da arte passa ao primeiro plano.

\footnotetext{
"Agora, disse Hegel, e ele estava certo, a arte 'nos convidava a uma contemplação intelectual' especificamente sobre sua própria natureza, esteja sua contemplação sob a forma de arte em um papel autoreferencial e exemplar ou na forma de filosofia real". ${ }^{20}$
}

A arte contemporânea, para Danto, seria uma chegada à maturidade da arte, que, por sua vez, teria abandonado o seu lado excessivamente materialista, sua preocupação com pigmento, superfície, forma, ou seja, se desfez daquilo que seria a sua

19 Hegel, G. W. F. Cursos de Estética (trad. Marco Aurélio Werle). São Paulo: Edusp, 2001, p. 35.

${ }^{20}$ Danto, op. cit, p. 164. 
pureza, no sentido que Clement Greenberg havia definido, para se aproximar da filosofia. Com isso, a arte passou a atribuir pouco sentido à visibilidade. A essência da arte deixou de ser o campo do visível para ser, prioritariamente, pertencente ao campo do pensamento. Assim, ainda que não se tenha tornado filosofia, ao menos passou a compreender a sua natureza filosófica.

Para o autor, mesmo que continue existindo arte após o "fim da arte", ela não está inserida numa narrativa, que terminou por volta dos anos de 1970 e 1980 . Tudo o que se fez de arte desde então seria um período pós-histórico, a história está acabada. Os artistas desse período passaram a ignorar os "critérios modernistas" ao mesmo tempo em que reconhecem que a narrativa do modernismo havia chegado ao fim.

Para Danto, que vem da tradição da filosofia analítica, o único pensador na história da estética que compreendeu o conceito de arte em toda a sua complexidade foi Hegel. Segundo o crítico americano "nenhum filósofo levou tão a sério a dimensão histórica da arte"21. Exceções são feitas a Nietzsche e também a Heidegger. Embora o pensamento de Nietzsche ${ }^{22}$ sobre história seja oposto à filosofia da história de Hegel e sua teleologia idealista, ele traz a idéia do "eterno retorno" que está ligada a uma concepção circular do tempo, como se a história fosse um grande relógio que tende sempre a recomeçar. Nesse sentido, haveria para Nietzsche certas engrenagens ocultas da história que são fixas. Trata-se de uma recusa do tempo histórico e linear, uma vez que as repetições pressupõem a temporalidade como eternidade. Por outro lado, talvez Danto salve Heidegger porque em A origem da obra de arte, publicada em 1950, ele escreveu que era cedo para afirmar se o pensamento de Hegel era verdadeiro ou falso.

\footnotetext{
${ }^{21}$ Idem, ibidem, p. 217.

22 Nietzsche, F. Escritos sobre história. Rio de Janeiro: Ed. PUC - Rio; São Paulo: Loyola, 2005.
} 
"A decisão final acerca do veredicto de Hegel ainda não foi
proferida [...]. A decisão acerca do veredicto de Hegel
será proferida, se o chegar a ser, a partir da própria
verdade do ente e a propósito dela. Mas até lá, o
veredicto de Hegel permanece válido. Só por isso é que é
necessária a pergunta sobre se a verdade, que o veredicto
anuncia, será definitiva, e o que se passa, se assim for." 23

Enquanto Heidegger questiona qual é a essência da obra de arte, Danto se confessa um essencialista ${ }^{24}$, ou seja, sua noção de arte tem algo de atemporal e é elaborada abstratamente pela reflexão, mesmo que ele cite inúmeros artistas ao longo de sua obra e se baseie em exemplos concretos. A história faria parte da extensão do conceito de arte. Ou então, seu conceito de arte, na verdade, é a culminância da história da arte: no caso, a autoconsciência de sua natureza filosófica. O problema é justamente a conciliação entre essa absoluta liberdade da arte contemporânea citada pelo autor e a sua noção essencialista de arte. Danto irá tentar conciliar seu essencialismo ao historicismo hegeliano, daí a enorme presença da narrativa em seu pensamento. Para ele, a arte sempre está ligada a uma narrativa, por isso nem tudo pode ser arte em todas as épocas. Citando uma passagem de Wölfflin ${ }^{25}$, Danto irá justificar pela narrativa o fato de caixa Brillo Box, de Warhol não ser vista como arte em todos os tempos, assim como o ready made de Duchamp. Portanto, nada impede que no futuro existam modos de arte hoje inimagináveis. $\mathrm{O}$ conceito filosófico de arte de Danto precisará ser universal e abarcar não apenas um estilo ou narrativa particular, mas tudo o que se conhece por arte ao longo da história. Se o que é ou não

23 Heidegger, Martin. A origem da Obra de Arte. (trad. Maria da Conceição Costa). Lisboa: Edições 70, 2008.

24 Conforme define Danto em Após o fim da arte, op. cit. p. 215: "Por 'essencialista' refiro-me à condição de ser uma definição mediante condições necessárias e suficientes, à maneira filosófica canônica."

25 Wölfflin, Heinrich. "Prefácio da sexta edição" Conceitos fundamentais da história da arte: o problema da evolução dos estilos na arte mais recente. São Paulo: Martins Fontes, 2000. p. IX-X. 
arte não depende mais apenas do campo sensível ou da história da arte, mas do pensamento, da filosofia da arte, de fato o que chega ao fim é certa tradição crítica calcada na visibilidade representada por Greenberg. Danto critica justamente o fato de as narrativas acabarem definindo a natureza da arte a partir de uma noção muito particular de arte, uma noção excludente. Entretanto, há uma multiplicidade e pluralidade na arte contemporânea que nenhum estilo ou nenhuma definição lateral poderia abarcar.

Para Danto, não seria correto dizer que a história da arte parou, como se o tempo deixasse de transcorrer, e sim que a história da arte está acabada "no sentido de que passou a ter uma espécie de autoconsciência, convertendo-se, de certo modo, em sua própria filosofia: um estado de coisas que Hegel previu em sua filosofia da história." ${ }^{26}$. De fato, mesmo que condene um percurso teleológico da história da arte moderna, Danto acaba o aceitando indiretamente. Para ele haveria uma lógica interna à história, certo encadeamento necessário ao menos até a arte moderna. A arte pós-histórica estaria livre disso, seria o momento da supressão dessa linha progressiva.

\section{A concepção de Merleau-Ponty}

$\mathrm{Na}$ filosofia de Merleau-Ponty não há fim da arte, como sugere Danto ao modo hegeliano, nem uma elevação da arte para a autoconsciência ${ }^{27}$ ou auto-reflexão filosófica. Para Merleau-Ponty, há diferença entre arte e filosofia e se a arte se tornasse filosofia ela deixaria de ser arte. Por isso será relevante entendermos certas proposições da arte conceitual, ou ao menos de uma tendência

\footnotetext{
${ }^{26}$ Danto, A. A transfiguração do lugar-comum. São Paulo: Cosac Naify, 2005, p. 26.

${ }^{27}$ Para Greenberg a pintura moderna de modo análogo a Kant, que investigou a possibilidade de conhecimento na filosofia, é uma pergunta sobre a possibilidade da pintura. A história da arte, tal como Greenberg nos narra, é uma história progressiva e que se desenvolve a partir da autoconsciência da arte.
} 
talvez não hegemônica do conceitualismo, que foi o clímax da autoconsciência filosófica da arte, e da pretensão de dissolução entre arte e filosofia. Interessante notar que a filosofia que irá aparecer no interior de grande parte do conceitualismo, inclusive no grupo inglês Art \& Language ${ }^{28}$, será justamente a filosofia analítica, que traz uma concepção de linguagem bastante instrumental e oposta à concepção de Merleau-Ponty.

Para Danto, a arte vai tentar ela mesma ter consciência filosófica sobre si em busca de um conceito universal da arte, elaborando filosoficamente seu próprio fundamento. Para MerleauPonty, a arte já é "filosofia selvagem", no sentido de que sua ação contém um pensamento que ela própria não explicita. Do mesmo modo, se Danto pode fazer filosofia a partir de Andy Warhol, do ordinário e do banal, é porque há nele uma filosofia tácita e não elaborada filosoficamente, mas expressa artisticamente, como já havia também na arte moderna.

O hegelianismo de Danto significará pensar a história da arte: a) por etapas, com começo, meio e fim, sendo o momento contemporâneo uma ruptura com o moderno que o antecede; b) guiada por um télos, certa autoconsciência da arte; c) contínua e progressiva (como condição cultural há mais liberdade na arte de hoje do que no passado, quando cada vanguarda se denominava a única possível; o contemporâneo tem a "autoconsciência de sua identidade" e é livre da teoria estética, livre do peso da história);

\footnotetext{
${ }^{28} \mathrm{Em} 1968$ os artistas Terry Atkinson, David Bainbridge, Michael Baldwin e Harold Hurrell fundaram o Art \& Language Press e, no ano seguinte, publicaram a "Revista de arte conceitual", onde manifestaram por palavras impressas e fotografias os principais tópicos da teoria da arte conceitual, o que já era por si só um trabalho de arte conceitual. Entre os pontos apresentados está a preocupação em redefinir o que é arte, a reformulação da independência crítica da arte, bem como a aversão à contemplação estética. Em geral a linguagem é compreendida pelo grupo antes como ferramenta ou documentação do que como força poética.
} 
d) destinada a ter uma conclusão, culminando no fim da história da arte, no momento pós-histórico.

Embora Danto pareça revelar uma posição intermediária entre a teoria interpretativa, que pressupõe uma coerência histórica de interpretações sobre o que é arte, e a teoria institucional, em que os representantes do mundo artístico teriam o poder de definir se um objeto é arte ou não, sua posição tende ao idealismo hegeliano. Mesmo que para Danto a arte seja uma questão de essência e não de valor, e que sua tese sobre história não valha necessariamente para o julgamento de uma obra singular, sendo a noção de tempo progressiva, parece não ser possível fugir plenamente da questão do valor. De todo modo, no debate sobre a exposição "Arte/ artefato", exibida em 1988 no Center for African Art, com curadoria da antropóloga Susan Vogel, Danto recusou que uma rede de caça Zande (África), exibida toda enrolada, pudesse ser compreendida com arte contemporânea. A arte para Danto seria "a resultante final do fazer artístico, da filosofia, da história e da crítica tomados conjuntamente." ${ }^{29}$ Para ele a rede de caça, que foi exibida no espaço "Galeria de Arte Contemporânea", é uma mera manifestação "prosaica" no sentido hegeliano.

Além disso, a história hegeliana, por mais que pareça presa ao tecido da contingência histórica, é conduzida pela necessidade, enquanto a de Merleau-Ponty pelo quiasma, pelo cruzamento da necessidade e da contingência. A contingência não é para o filósofo francês apenas o campo da irracionalidade e da falta de sentido, como tradicionalmente foi compreendida. Por outro lado, a racionalidade também não está presa à necessidade, como se a razão operasse segundo uma regra necessária. Para Merleau-

\footnotetext{
${ }^{29}$ Gell, Alfred. "A rede de Vogel: armadilhas como obras de arte e obras de arte como armadilhas". Revista do Programa de Pós-Graduação em Artes Visuais EBA - UFRJ, 2001. p. 178.
} 
Ponty, poderá haver uma racionalidade na contingência na medida em que ela possui sentido e significação, uma vez que é possível conhecer as circunstâncias pelas quais o acontecimento ocorre. A contingência é indeterminação porque não pode ser prevista, ou seja, nunca poderá ser determinada. Mas se forem compreendidas as condições em que um acontecimento se dá a contingência não será irracional. E assim, o contingente se torna um possível, porque o possível não é indeterminado como o contingente. Um evento contingente acontece segundo certas linhas de força e ações que o fizeram acontecer e o tornaram possível. Por isso, a concepção de Merleau-Ponty é uma concepção alargada de razão e durante toda a história o campo do possível sempre esteve aberto, isso não é um privilégio do momento atual.

Segundo Merleau-Ponty, uma vez que a filosofia tal como Hegel apresenta é um saber absoluto, uma totalidade exprimida a partir de um sistema, a história para Hegel não é verdadeiramente história. Sendo uma história universal, compreendida, ela é algo já acabado, constituído e, portanto, morto. "Inversamente, a história sendo puro fato ou acontecer, introduz no sistema em que se incorpora um movimento interior que o destrói. ${ }^{\prime 30} \mathrm{O}$ sentido da história só pode ser um sentido em devir:

\footnotetext{
"Uma filosofia é, necessariamente, uma história filosófica, uma troca entre problemas e soluções em que cada solução parcial transforma o problema inicial, de modo que o sentido do conjunto não lhe é pré-existente senão da mesma maneira que um estilo é pré-existente às obras e parece anunciá-las extemporaneamente." 31
}

Merleau-Ponty irá fazer uma crítica à dialética como uma espécie de máquina que produz acontecimentos, uma vez que a dialética estabelece completamente a história e a temporalidade,

\footnotetext{
30 Merleau-Ponty, Elogio da Filosofia. Lisboa: Guimarães Editores, 1993, p. 6364.

${ }^{31}$ Idem, ibidem, p. 27-28.
} 
determinando as etapas pelas quais ela necessariamente deve passar e, além disso, do modo como cada etapa irá suceder a próxima, como se pudesse calcular como será o futuro, um futuro já preconcebido.

Em lugar de situar cada filósofo num ponto determinado do sistema que Ihe daria sentido, trata-se de reencontrar a verdade própria a cada filosofia e de cada filósofo. E mesmo que se faça a crítica do pensamento do outro, trata-se de mantê-lo e conserválo, porque há nele um impensado, algo que o outro não pensou explicitamente, mas que foi posto por ele ao pensar o que pensou e que pode ser recuperado e pensado pelo seu leitor. O impensado é aquilo que, ao pensar, um outro nos dá a pensar; aquilo que ele próprio não pensou, mas que seu pensamento fez surgir para seu leitor como algo a pensar. Há, assim, também na noção de fim da história da arte algo que deve ser compreendido e transpassado por dentro. A tese de Danto não pode ser simplesmente refutada, uma vez que, efetivamente, não é mais possível fazer uma história da arte tal como ela foi feita até o modernismo. É preciso ler Danto da maneira como Merleau-Ponty propõe que se leia Hegel. De fato, no caso de Hegel, mesmo que sua filosofia seja de algum modo o túmulo de todas as filosofias, uma vez que elas perdem seu poder de impacto e são transformadas não nelas mesmas, mas na filosofia dele, é fundamental compreendermos não só seu pensamento, mas o próprio hegelianismo como uma posteridade gerada pela própria obra hegeliana. Segundo Merleau-Ponty:

"Se Hegel quer dizer que o passado, à medida em que se
distancia, se transmuda em sentido, e que podemos a
posteriori retraçar uma história inteligível do pensamento,
tem razão, desde que nesta síntese cada termo
permaneça na totalidade do mundo até então, e o 
encadeamento das filosofias as mantenha todas em sua posição de significação abertas." ${ }^{32}$

Manter as significações abertas significa pensar a história não como algo definido e encerrado, mas como instituição de acontecimentos e cada um deles, seja artístico ou filosófico, como uma matriz de significação. As análises que Merleau-Ponty faz da historicidade da obra de pensamento serão válidas também para a arte e o campo da ação. A ação de um artista pode ser matriz e por isso produzir uma sequência de ações interligadas e dotadas de sentido que irão gerar um futuro, negando uma concepção linear de história, quer uma linearidade mecanicista, quer dialética (no sentido hegeliano). É a noção de instituição que permitirá a abertura de um campo de experiências que se interligam. E cada uma das experiências, dotada de sentido e dando sentido à experiência seguinte, forma uma sequência, uma história. Isso irá depender da fecundidade da ação, do trabalho de arte por ela gerado ou de sua capacidade de se abrir para novas experiências.

A diferença ontológica entre um acontecimento artístico e um acontecimento não-artístico será a sua fecundidade. Para que uma ação artística não seja superficial e insignificante terá que abrir caminho e, do seu próprio interior, gerar um porvir. Está contido no presente, numa ação atual, aquilo que ainda virá. Não é possível determinar como, quando e tampouco o que virá, mas apenas que algo virá. O futuro é, portanto, o que é prometido pelo próprio presente, mas o presente não contém previamente o que irá acontecer, apenas contém uma abertura, uma possibilidade para que outras coisas aconteçam a partir dele. Para Merleau-Ponty é impossível predeterminar o curso do tempo e por isso critica o hegelianismo. $O$ engano da dialética é encontrar no presente o

32 Idem, "A linguagem indireta e as vozes do silêncio", Textos escolhidos, São Paulo: Abril Cultural, 1975, p. 364. 
pressuposto que será posto pelo futuro. E com isso conceber o Espírito como movimento temporal e inteligível rumo à consciência de si mesmo. Como se fosse possível julgar a história a partir da ideia, de um conceito universal de história, e como se fosse possível estar fora da história, ignorando a sua própria inerência histórica. Também não se pode julgar a arte a partir de uma ideia de arte, ou seja, pensar que a verdadeira natureza da arte seja a chegada de sua autoconsciência, momento em que é proclamada a sua identidade com a filosofia, ou seja, ela mesma decretando o seu fim.

Para Merleau-Ponty, cada trabalho de arte, como o presente, é uma matriz de abertura, uma vez que ele próprio está recolhendo um passado, que já foi presente, e que se abriu para ele. Assim opera a instituição, como advento de algo novo.

\begin{abstract}
"Há simultaneamente descentramento e centramento dos elementos de nossa própria vida, movimento de nós para o passado e do passado reanimando para nós, e o trabalho do passado contra o presente, não acaba em uma história universal concluída, em um sistema completo de todas as combinações humanas possíveis no que concerne a tal instituição como a afinidade, por exemplo, mas a um quadro de diversas possibilidades complexas, sempre ligadas a circunstâncias locais sobrecarregadas de um coeficiente de facticidade e, portanto, nós não podemos dizer que um seja mais verdadeiro que outro, embora nós possamos dizer que um é mais falso, mais artificial e tem menos abertura a um porvir menos rico. Esses fragmentos de análises levam a uma revisão do hegelianismo, da ligação viva, atual, originária entre os elementos do mundo, mas que a põe no passado, a subordinando à visão sistemática do filósofo" ${ }^{\prime 33}$.
\end{abstract}

Por isso a perspectiva de Merleau-Ponty não é essencialista como a de Danto e não irá depender de nenhuma estrutura histórica objetiva e necessária. Poderíamos dizer, a partir da noção de instituição do filósofo francês, que a Caixa Brillo Box, de Warhol,

33 Merleau-Ponty, "L'institution", op. cit. p. 64-65. 
é um trabalho instituinte e não instituído tanto porque abre um porvir para a própria arte quanto porque dá o que pensar, o que falar e o que dizer, diferente das outras caixas vendidas em supermercados. O trabalho de Warhol permite que Danto extraia dele uma filosofia da arte, uma filosofia sobre a autoconsciência da arte, mesmo que essa filosofia dependa de certa concepção teleológica de história da arte. Mesmo os objetos cotidianos e o mundo instituído podem também dar a pensar, podem provocar e estimular a invenção de trabalhos de arte e de pensamento. Não são poucos os artistas contemporâneos que olham para o não artístico para fazerem dele arte. Nesse sentido, não seria necessária uma teoria da arte que abrangesse toda e qualquer arte em todos os tempos, tampouco uma rígida oposição ontológica entre arte e não-arte. Sob o instituído, sob a arte instituída ou sob a linguagem falada, clara e direta, há também uma arte instituinte, que irá instituir o ainda não dito, há uma linguagem falante e indireta.

Se a arte não mais se distingue visivelmente dos objetos mundanos e não artísticos e se é possível fazer arte com tudo, os próprios objetos não artísticos podem se abrir para a reflexão. Mesmo porque para Merleau-Ponty a reflexão não é privilégio do sujeito ou de uma consciência constituinte. Não precisará existir um conceito universal que define o que é ou não arte senão a própria expressão da coisa feita ou apropriada pelo artista como arte. Como escreve Merleau-Ponty, a pintura nasce nos desenhos de Lascaux porque ali está dito que o mundo é algo a ver, algo que se dá a ver e a pintura não faz mais do que interrogar o enigma da visão, seja qual for a coisa manifestada pela ação do pintor.

Além disso, reflexão não é apanágio da consciência de si ou do sujeito do conhecimento como inerência de si a si porque sua primeira manifestação é corporal, isto é, nosso corpo é 
reflexionante, realiza reflexões. Como diz Merleau-Ponty, "há inerência daquele que vê naquilo que vê". ${ }^{34}$ Meu corpo é vidente e visível, tocante e tocado, pensante e pensado simultaneamente e por isso no corpo "não se sabe mais quem vê e quem é visto". ${ }^{35}$ Meu olhar se dá ao mesmo tempo em meu olho e nos próprios objetos que vejo, meu pensamento se dá no meu intelecto e no próprio mundo simultaneamente. Não é casual que muitos pintores digam que se sentem vistos pelas coisas e que muitos escritores afirmem que se sentem falados pela pelas palavras.

Uma "teoria da história da arte" em Merleau-Ponty poderia ser localizada na noção de advento, na concepção de que em cada trabalho há um excesso de sentido em relação às intenções deliberadas do artista.

\begin{abstract}
"Consistindo o próprio do gesto humano em significar para além de sua mera existência de fato, em inaugurar um sentido, segue-se que qualquer gesto é comparável a qualquer outro, que formam todos uma única sintaxe, que cada qual é um princípio (e uma sequência), que por não estar, como o evento, exaurido em sua diferença e para sempre concluso, prenuncia uma sequência e uma reincidência, fazendo-se sentir além da simples presença e mostrando-se por isso aliado ou cúmplice a todas as outras tentativas de expressão." ${ }^{36}$
\end{abstract}

Não há, portanto, um Espírito da arte escondido sob os acontecimentos e sob o mundo da percepção e que iria se manifestando de tempos em tempos. Não há uma história pensada a partir de relações causais e leis próprias que se daria para além dos eventos, mas sim a ideia de que a arte suscita mais arte e significações ainda não pensadas.

Cabe ao filósofo abandonar as abstrações e generalizações assim como a ilusão de se posicionar numa perspectiva absoluta

\footnotetext{
${ }^{34}$ Idem, "O olho e o espírito". Textos escolhidos, São Paulo: Abril Cultural, 1975. p. 278.

${ }^{35}$ Idem, ibidem, p. 282.

${ }^{36}$ Idem, "A linguagem indireta e as vozes do silêncio". op. cit. p. 353.
} 
que pode observar a história como uma totalidade acabada. A filosofia precisa deixar de se compreender como separada do mundo e se realizar na própria concretude do mundo, ou seja, se aproximar da lógica imanente a outras experiências, em vez de substituir o mundo pelo pensamento do mundo. $O$ que se trata de fazer é recolocar na práxis humana o conhecimento ou, nos termos de Merleau-Ponty, "recuperar a dignidade ontológica do sensível" sem ter que optar entre a matéria e o espírito.

\footnotetext{
"O que se deve censurar no filósofo e no Hegel dos últimos anos é imaginarem que podem, e podem sozinhos, apenas pelo pensamento, proporcionar a verdade de todas as outras existências, integrá-las, ultrapassá-las e, do fundo de sua sabedoria, obter a revelação do sentido da história que os demais homens se limitariam a suportar. Filosofar é uma maneira de existir entre outras coisas, e, como diz Marx, não podemos vangloriar-nos de esgotar a 'existência religiosa', a 'existência política', a 'existência jurídica', a 'existência artística', nem, em geral, a 'verdadeira existência humana' através da 'existência puramente filosófica'."137
}

Assim como a reflexão corporal desfaz a oposição entre subjetivo e objetivo, assim também não poderá persistir na história a oposição metafísica entre o necessário e o contingente. E o contingente jamais poderá ser engolido pelo necessário, se o fosse a história estaria já traçada antes mesmo de se realizar e haveria uma lógica da história que se sucede numa certa ordem em direção a um acabamento e a uma conclusão que seguramente serão realizados.

Vemos assim que a filosofia de Merleau-Ponty, ao destruir o dualismo essência versus aparência vai encontrar na noção de corpo próprio uma espécie de síntese que permite a superação da pura interioridade e da pura exterioridade. O corpo é reflexionante e, portanto, acaba com a ideia de uma consciência desencarnada

37 Idem, "Marxismo e Filosofia". Textos escolhidos, São Paulo: Abril Cultural, 1975. p. 269. 
ou da coisa como matéria inerte e natural. O mundo e nós somos feitos da mesma carne. O que irá singularizar cada um de nós e as próprias coisas serão segregações de diferenças que se formam e se diluem na carne do mundo. O trabalho de arte surge da diferença, de uma pequena cisão no interior da indivisão, uma cisão que não divide, mas apenas diferencia: o corpo do pintor traz ao visível um invisível, a obra, sem sair da linguagem. A arte é emblema de nossa encarnação e da impossibilidade de separar consciência e corpo, consciência e mundo, sujeito e objeto. A arte irá assim nos ajudar a rever o modelo clássico do Espírito como consciência pura e poder absoluto, como posse intelectual do mundo, mas também recusar o cientificismo objetivista. Será preciso renunciar tanto à subjetividade quanto à objetividade plenas.

As questões hegelianas sobre o fim da arte e também a ideia de fim da metafísica irão se refletir no discurso de artistas contemporâneos ligados às vertentes conceituais como, por exemplo, Joseph Kosuth, mesmo que ele não seja um artista hegemônico. Nesse sentido, a filosofia de Merleau-Ponty poderá ser vista como um contraponto ao conceitualismo, tendência genérica e difusa que merece ser repensada.

Apesar da ideia de "fim da metafísica" também aparecer no trabalho de Mira Schendel, de historiadores ${ }^{38}$ a situarem entre o "conceitual e não conceitual", de dizerem que a fisicalidade de seu trabalho "pode ser arte ou não o ser", o pensamento de MerleauPonty também irá nos ajudar na sua compreensão. Na verdade, sob o conceitualismo, esse amplo guarda-chuva que parece abrigar grande parte da arte desde os anos de 1960 e sob o qual quase tudo cabe, foi útil para os que tentaram distanciar o trabalho de

38 Particularmente Aracy Amaral em "Mira Schendel: os cadernos". Arte e meio artístico: entre a feijoada e o x-burguer. São Paulo: Nobel, 1983. 
Mira Schendel do que as correntes pós-modernistas convencionalmente chamaram de formalismo, outro termo que no Brasil é tão genérico que talvez não designe rigorosamente muita coisa. Se há algum vínculo entre o trabalho de Schendel e o conceitualismo é o fato de eles serem contemporâneos, como de resto também era o neoconcretismo. Talvez as coincidências entre a arte do sul e do norte da América terminem por aí.

A dimensão filosófica da arte se revelará no trabalho de Schendel na medida em que nele irá surgir uma série de indagações sobre o vazio, sobre a linguagem como corpo visível e sobre o tempo. E em vez de enunciados puros ou de conceitos ocuparem o centro de sua obra, como se fosse possível se desfazer de qualquer materialidade, é na própria ação originária e no interior do trabalho de Schendel que poderemos vislumbrar sua dimensão filosófica. É possível ver nele uma resposta ao dualismo clássico, algo também perseguido pela filosofia contemporânea à artista e, particularmente, por Merleau-Ponty. É no momento mesmo em que teria se dado o fim da história da arte que seu trabalho está sendo elaborado. Nosso ponto de partida é que o trabalho de Schendel é instituinte e a noção da temporalidade presente nele pressupõe a abertura para o porvir. As questões levantadas nesta introdução parecem indiretamente convergir no trabalho de Schendel, que dará uma resposta própria para elas. Nesse sentido, algumas noções tratadas nessa introdução como a noção de corporeidade, transparência e experiência serão retomadas na análise sobre a artista. 


\section{Arte conceitual e o fim da arte}

A ideia hegeliana de fim da arte encontrou solo fértil para se desenvolver na arte contemporânea. Mesmo que Hegel pense a arte a partir de uma concepção idealista e num sentido histórico bastante preciso, sua tese se desdobrou de diferentes modos. Não se trata de morte da arte, de que ela tenha terminado completamente, mas de que, diferentemente da arte grega antiga, ela não corresponda mais ao Espírito. Vale para a arte o que Hegel diz sobre os povos: cada um deles tem um lugar determinado na história do Espírito e, cumprindo seu papel, cada povo continua a existir empiricamente, mas passa a inexistir historicamente. Egípcios, gregos e romanos terminaram seu papel na história; Egito, Grécia e Roma continuam a existir, mas se tornaram histórica e espiritualmente insignificantes. Assim também com a arte, cujo papel terminou com o advento da filosofia como autoconsciência do Espírito. Essa noção hegeliana de fim da arte é expressamente citada pelas vertentes conceituais e também por pensadores diversos nos últimos anos.

Do crítico e poeta Ferreira Gullar ${ }^{39}$ ao historiador Giulio Carlo $\operatorname{Argan}^{40}$, do crítico Arthur Danto ao historiador alemão Hans Belting, cada um abordou o tema sob um ponto de vista e com objetivos diferentes $^{41}$, mas todos se referem ao fato de que a arte

\footnotetext{
39 Gullar, F. Argumentação contra a morte da arte. Rio de Janeiro: Revan, 2005 [1993]. Vale a pena diferenciar os textos sobre arte de Gullar, especialmente os das duas últimas décadas, em geral com posições bastante conservadoras, daqueles do final dos anos de 1950 e década de 1960, de caráter experimental e fundamentais para a arte de vanguarda. Analisamos alguns de seus mais importantes textos como o "Manifesto neoconcreto" e a "Teoria do não-objeto", em nossa dissertação de mestrado: O pensamento em processo da obra de Hélio Oiticica. FFLCH-USP, 2004.

${ }^{40}$ Argan, G. C. Arte e Crítica de Arte. Lisboa: Estampa, 1995 [1988].

${ }^{41}$ Gianni Vattimo em seu livro O Fim da Modernidade: niilismo e hermenêutica na cultura pós-moderna. São Paulo: Martins Fontes, 2007 [1985], também dedica um capítulo ao tema: "Morte ou ocaso da arte". O autor a vê na perspectiva da morte da metafísica em geral.
} 
das décadas de 1960 e 1970 provocou revoluções que, no limite, rompem com certa noção de arte ou de história da arte.

Para o Gullar, que parte de premissas próximas das de Argan, as vanguardas destruíram o sistema da linguagem artística e a levaram ao seu esgotamento. Além disso, a crítica de arte contemporânea, com medo de errar ou parecer retrógrada como a crítica feita à arte moderna, teria passado a se sentir na obrigação de tudo aprovar. Para o poeta, que escreveu essas observações já nos anos de 1990, bem depois de seus brilhantes textos dos anos de 1950 e 1960, pouco parece importar as dificuldade o modernismo se deu no País e sua eterna incompletude. A despeito da imensa pluralidade da produção artística e das diversas e heterogêneas posições críticas na arte contemporânea, haveria para Gullar uma conivência entre críticos e artistas que teria aberto caminho para o oportunismo e extravagâncias estéticas. Já Argan, com argumentos menos generalizantes e mais precisos, defende a ideia de que a crise da arte é um produto da crise da crítica. Ao assimilar a arte, explicá-la e integrá-la na realidade social, a crítica acabou destruindo a arte. Desse modo, haveria duas hipóteses para o historiador. Ou a arte se integra na história geral da cultura, diluindo-se na vida ao partir de "premissas não-artísticas", ou, por outro lado, busca um "absoluto monadismo", uma arte fechada sobre si e independente do mundo, como na vertente que perseguiu a pura objetividade da arte. Exemplos possíveis da segunda hipótese poderiam estar nos trabalhos de Joseph Kosuth, como Four words four colors, de 1965, ou One and three chairs, de 1974, que acabam redundando numa tautologia.

"E ainda, se a única formalização possível do conceito de arte é a operação artística, esta mesma formalização do conceito de arte destrói a obra de arte como tal, de modo que a arte e a crítica se destruiriam. Considerando a primeira hipótese, a crítica seria o agente determinante 
da morte da arte em sentido hegeliano, ou seja, a dissolução do conhecimento artístico no conhecimento filosófico; considerando a segunda, a arte determinaria 'criticamente' a sua própria morte, excluindo-se de qualquer possibilidade de relação com a realidade do mundo" ${ }^{\prime 2}$

A arte conceitual escancarou o impasse das artes artesanais, como a pintura e escultura, que se configurava desde o século XIX, com a idade industrial. Para artistas conceituais como Kosuth ou Sol Lewitt, o planejamento do trabalho e as decisões devem ser formulados de antemão e a execução é uma questão que pode ser delegada, uma vez que o conceito não será mais modificado durante o processo de realização do trabalho. Além disso, é recorrente nos artistas chamados de conceituais a compreensão de que as ideias eram a verdadeira essência da arte e que, portanto, toda experiência sensível seria secundária. Assim, a arte conceitual tende para a desmaterialização. Contra a ideia de que a arte esteja restrita à pintura e à escultura, para Kosuth a indagação sobre os fundamentos do conceito de arte seria a melhor definição sobre o que é uma obra de arte conceitual. Desse modo, sequer seria preciso existir um objeto palpável e visível para que a arte de fato existisse. Em sua exaltação para que o artista tenha o domínio pleno sobre o discurso de seu trabalho, um texto teórico sobre a arte já é um trabalho de arte. Não que isso inviabilize obras calcadas na visibilidade, mas na arte conceitual, para saber se algo é ou não arte, não é o mundo da percepção que está no centro, e sim o pensamento, campo tradicional da filosofia.

Em 1969, Kosuth escreveu Arte depois da Filosofia ${ }^{43}$ que além de um texto teórico é compreendido como um trabalho de arte. Assim, as ideias e a linguagem, compreendidas no sentido da

${ }^{42}$ Argan, "A crise da crítica e a crise da arte", op. cit. p 161.

43 Kosuth, Joseph. "A arte depois da filosofia". Escritos de artistas: anos 60 e 70. Seleção e comentários Glória Ferreira e Cecília Cotrim. Rio de Janeiro: Jorge Zahar Ed., 2006. p. 217. 
filosofia analítica, constituem o núcleo da noção de arte para os conceituais e dispensaria a experiência visual e sensorial, tratadas como irracionais. Seu texto inicia com uma referência direta a última proposição do Tractatus Logico-Philosophicus de Wittgenstein: "sobre aquilo de que não se pode falar, deve-se calar". ${ }^{44}$ Kosuth, como os positivistas, usou essa proposição para decretar o fim da metafísica e afirmar que a filosofia teria acabado, uma vez que ela seria o campo da confusão e da tentativa de dizer o indizível. Entretanto, para o filósofo vienense, aquilo sobre o qual nada poderíamos falar é o que realmente importa na vida. Assim, o essencial talvez seja aquilo sobre o qual o filósofo nenhuma linha escreveu porque a linguagem não daria conta. A ciência parecia ser o único modo de se chegar à verdade, uma vez que seria possível verificar objetivamente o pensamento científico e, incrivelmente, a arte também seguiu esse caminho, afirmando o fim da filosofia.

Para o Wittgenstein do Tractatus Logico-Philosophicus a linguagem é pura transparência. Ela é compreendida como proposição, ou seja, como predicação (S é P), como denotação (Isto é $\mathrm{x}$ ) e como determinação completa ( $\mathrm{S}$ é $\mathrm{x}$ porque lhe pertencem os predicados $a, b, c, d, r, m$ - que são todos os seus predicados - e não the pertencem os predicados não-a, não-b, não$c$, não-d, não-r, não-m). Desse modo, se uma proposição possui um sentido, ele será inteiramente determinado. E se o enunciado for verdadeiro ele corresponderá completamente aos objetos e fatos. Wittgenstein busca uma linguagem logicamente ordenada por enunciados elementares. Conforme elaborado pelo filósofo no Tractatus: "O fim da filosofia é o esclarecimento lógico dos pensamentos. [...] Cumpre à filosofia tornar claros e delimitar precisamente os pensamentos, antes como que turvos e

\footnotetext{
${ }^{44}$ Wittgenstein, L. Tractatus Logico-Philosophicus (trad. Luiz Henrique Lopes dos
} Santos). São Paulo: Edusp, 2008. p. 281. 
indistintos". ${ }^{45}$ Portanto, o silêncio da filosofia decorre para ele da impossibilidade de ter proposições ou predicações denotativas e determinação completa para todo e qualquer objeto metafísico, que por isso não pode ser "dito" - a ciência pode falar pelas proposições da ciência natural, mas a filosofia não pode.

Em meio a uma miscelânea de referências rápidas à história da filosofia antiga, além de Descartes, Leibniz, Kant e Hegel, o texto de Kosuth tem um tom claramente cientificista a ponto de questionar se a inteligência do homem contemporâneo dispensaria a filosofia tradicional. Segundo Kosuth, no século XX a filosofia chegou ao fim e a arte ocupou o seu lugar. Em seu texto, o artista introduz a ideia de que a filosofia de Hegel seria uma superação de Hume, do Iluminismo e de Kant, e que serviu de pretexto para crenças religiosas e também como alternativa para a mecânica de Newton. Assim, Hegel teria dado uma saída para o dualismo entre Teologia e Ciência:

\begin{abstract}
"Hegel parecia oferecer uma solução aceitável para o conflito entre teologia e ciência. O resultado da influência de Hegel foi que os filósofos contemporâneos, em sua grande maioria, são na realidade pouco mais do que historiadores da filosofia, Bibliotecários da Verdade, por assim dizer. Começamos a ficar com a impressão de que não há 'nada mais para ser dito'. E certamente, se compreendermos as implicações do pensamento de Wittgenstein, e do pensamento influenciado por ele ou que o seguiu, a filosofia 'continental' não precisa ser considerada seriamente aqui". ${ }^{46}$
\end{abstract}

Nesse momento do texto Kosuth coloca uma nota de rodapé:

"Refiro-me com isso ao existencialismo e à fenomenologia. Mesmo Merleau-Ponty, com sua posição intermediária entre empirismo e racionalismo, não foi capaz de expressar a sua filosofia sem o uso de palavras (portanto usando conceitos); e seguindo esse caminho,

\footnotetext{
${ }^{45}$ Wittgenstein, L. op. cit. (4.112). p. 177.

${ }^{46}$ Kosuth, Joseph. "A arte depois da filosofia". op. cit. p. 211.
} 
como alguém pode discutir a experiência sem distinções nítidas entre nós e o mundo?"47

Quanto o trecho citado, fica a dúvida se a Teologia é identificada por Kosuth à metafísica. Além disso, é importante lembrar que Ciência, para Hegel, é o saber total que o Espírito alcança em cada época e não as ciências particulares, Ciência é a Filosofia. Parece que o que justifica a afirmação dos filósofos como Bibliotecários da Verdade é o fato de Hegel julgar que o Espírito Absoluto está realizado e que, agora, só há uma história empírica de acontecimentos e nenhuma verdade nova no campo da filosofia. Para Kosuth, a filosofia teria chegado ao fim e se tornado arte. De fato, parece existir uma confusão na relação entre Hegel e Wittgenstein. Nada haver para dizer, em Hegel, é bem diferente do não poder dizer, em Wittgenstein.

Em relação à nota de Kosuth sobre Merleau-Ponty, há três problemas gritantes: a) dizer que Merleau-Ponty mistura racionalismo e empirismo, quando critica ambos e não há como misturá-los, pois seus fundamentos são opostos; b) que MerleauPonty não foi capaz de expressar sua filosofia sem palavras e conceitos, o que mostra o total desconhecimento por parte de Kosuth dos textos de Merleau-Ponty sobre a linguagem c) justamente porque Merleau-Ponty não é mistura de empirismo e racionalismo é que ele não nos torna indistintos com o mundo. Essa indistinção é empirista: tudo é coisa; ou é racionalista, tudo é ideia. Merleau-Ponty não trabalha com distinções e sim com diferenças e diferenciações.

A filosofia de Merleau-Ponty se volta tanto contra o positivismo, que Kosuth parece abraçar, como também contra o

${ }^{47}$ Idem, ibidem. 
cientificismo e o pequeno racionalismo ${ }^{48}$. Segundo Merleau-Ponty, a experiência é abertura para o mundo, abertura para algo diferente de nós, saída do instituído para o instituinte ${ }^{49}$. Opondo-se às tradições rivais do intelectualismo e do empirismo, MerleauPonty investiga a noção de experiência. Além disso, ergue-se contra a ideia de que possa existir uma coincidência entre o pensamento e o ser, como imaginam as filosofias da consciência e da representação desde Descartes, ou como imaginam as ciências, ao supor que o objeto científico é idêntico à totalidade do real e a sua explicação completa. Pelo contrário, a experiência é a afirmação da impossibilidade dessa coincidência, ela "é o meio que me é dado de estar ausente de mim mesmo, de assistir por dentro à fissão do Ser, ao término da qual somente me fecho sobre mim. ${ }^{\prime 50}$ Para Merleau-Ponty, será possível pensar em experiência contra as distinções metafísicas tradicionais (corpo/alma; coisa/consciência; fato/ideia; eu/mundo), que sustentam o discurso da filosofia e da ciência de cunho positivista. Se, para ele, a arte ocupa um lugar exemplar para a filosofia é exatamente porque o trabalho de arte é aquilo que nos faz voltar ao originário, ao mundo pré-reflexivo, onde as oposições entre subjetividade e objetividade, espírito e corpo ainda não se deram. Contra as distinções metafísicas e científicas, Merleau-Ponty propõe uma ontologia do Ser de indivisão, feito de dimensões entrelaçadas e

\footnotetext{
48 Merleau-Ponty faz uma crítica ao cientificismo, que limita a racionalidade à razão científica. Seu objetivo não é de modo algum fazer uma crítica à ciência em geral, afinal o filósofo irá reconhecer na própria ciência, no caso a nova psicologia, descobertas originais que Ihe permitirão identificar o fundamento comum entre dicotomias tradicionais. Sua filosofia irá justamente criticar o pequeno racionalismo do início do século $\mathrm{XX}$, que tentou explicar o Ser pela ciência, como se a ciência pudesse dar conta de responder todas as indagações humanas e, ao mesmo tempo, esquecer a ideia de "infinito positivo" do século XVII, segredo do grande racionalismo na união das dualidades metafísicas. Sobre o Grande Racionalismo cf. Merleau-Ponty. Signos. "Por toda parte e em parte alguma", cap. IV, São Paulo: Martins Fontes, 1991. p. 161-169 [1960]

${ }^{49}$ A noção de instituição será discutida adiante.

${ }^{50}$ Merleau-Ponty, M. O olho e o espírito. São Paulo: Cosac \& Naify, 2004. p. 42.
} 
não de divisões, e no qual tudo que é, o é por diferenciação imanente. Por isso, ao falar em "fissão do Ser", fala de uma cisão que, simultaneamente, não separa completamente nós do mundo e efetua a diferença entre um e outro. A experiência de ver se realiza num vidente que se diferencia do visto, mas que, ao mesmo tempo, é ele também visível para os outros e para si; a experiência de pensar se realiza num pensante que se diferencia do pensado, mas que, ao mesmo tempo, se pensa a si mesmo ao pensar o que é outro que ele. Assim também, o sensível, o dizível e o pensável não são idênticos, são diferentes, mas porque sua diferença não é uma distinção metafísica, há comunicação entre eles e passagem de um ao outro. A diferenciação é própria da experiência, e é exatamente por isso que a experiência não separa o sujeito do objeto experimentado, pois ambos são dimensões do mesmo Ser, diferenças no mesmo Ser. As diferenças existem, são dimensões do mesmo Ser, que as une sem identificá-las e que as distingue sem separá-las. Assim como não existe figura sem fundo, não pode existir experiência alguma sem um fundo: não pode haver experiência do visível sem que este se destaque de um fundo invisível; não pode haver experiência da linguagem sem que a fala se destaque de um fundo silencioso; não pode haver experiência do pensamento sem que o pensado se destaque de um fundo impensado. Justamente por isso, a experiência de ver não esgota o visível, a de falar, não esgota a linguagem, a de pensar não esgota a ideia. O invisível não é o que não pode ser visto e sim o que permite ver; o silêncio não é o que não pode ser dito, mas o que permite falar; o impensado não é o que não pode ser pensado, mas o que permite pensar. Segundo Marilena Chaui:

" a experiência já não pode ser o que era para o empirismo, isto é passividade receptiva e resposta a estímulos sensoriais externos, mosaico de sensações que se associam mecanicamente para formar percepções, 
imagens e ideias; nem pode ser o que era para o intelectualismo, isto é, atividade de inspeção intelectual do mundo. Percebida, doravante, como nosso modo de ser e de existir no mundo, a experiência será aquilo que ela sempre foi: iniciação aos mistérios do mundo. ${ }^{\prime 51}$

A despeito das brevíssimas colocações de Kosuth sobre a filosofia de Merleau-Ponty, a fenomenologia da linguagem desse filósofo, a contrapelo das ideias do artista, talvez seja relevante para a própria discussão da arte conceitual, uma vez que a linguagem escrita, ao contrário das artes visuais, já parte de uma cultura sedimentada pela fala, de uma língua comum e, portanto, sem a necessidade de "retomar a cada vez sua tarefa no início." 52 Segundo Merleau-Ponty, as artes da linguagem permitem chegar a um campo onde as vozes do silêncio não alcançam.

A arte conceitual consiste em questionar a natureza da arte e, ao fazer isso, nega a importância da "linguagem" da arte tradicional, isto é, presa ao campo da visibilidade como a pintura ou a escultura, que são vistas como um "resíduo físico das ideias de um artista". Um trabalho de arte conceitual em seu sentido mais próprio é uma proposição clara e inequívoca. Cabe ao artista conceitual criar novas proposições e apresentá-las no interior do campo da arte, sem precisar levar em conta qualquer pressuposição empírica. Desse modo, a arte conceitual se dá no interior da lógica, investigando não o campo da percepção, mas a definição do que é a arte. Nesse sentido, a arte conceitual se aproxima da teoria da arte e despreza a arte como estética, ou seja, ligada ao campo sensível:

"A arte é análoga a uma proposição analítica e [...] a existência da arte como uma tautologia é o que permite à

\footnotetext{
${ }^{51}$ Chaui, Marilena. Experiência do pensamento. São Paulo: Martins Fontes, 2002. p. 161.

52 Merleau-Ponty. Fenomenologia da Percepção. São Paulo: Martins Fontes, 1996. p. 258.
} 
arte permanecer 'indiferente' com relação às conjecturas filosóficas" ${ }^{\prime 53}$

$\mathrm{Na}$ verdade, a limitação da "linguagem da arte" só surge quando ela é concebida como ideal e pura, como se pudesse traduzir sem equívocos pensamentos e sentimentos. Nesse sentido, a linguagem da arte conceitual é apenas instrumental, uma linguagem supostamente perfeita e transparente. Mas a linguagem, como vimos, não traduz significações e sim é habitada por elas. 0 sentido não está fora do mundo, uma vez que ele não pode ser anterior nem exterior à palavra. A arte exprime o inexprimível porque sua linguagem é alusiva e indireta. $O$ artista não copia nem traduz pensamentos, mas se deixa fazer e refazer por eles. É do indizível e do invisível que surgem o dizível e o visível. É o silêncio que torna possível a expressão e a invenção de novos sentidos.

A linguagem, tal como Merleau-Ponty a compreende, é uma totalidade, estrutura de puras diferenças internas e não um conjunto ou soma de partes positivas atomizadas. ${ }^{54}$ Trata-se de um sistema de equivalências e não um conjunto de sons e letras, de elementos positivos que iriam substituir o mundo. A linguagem é fecundidade e por isso tem o poder de eclosão.

"Reporto-me à palavra assim como minha mão se dirige para o lugar de meu corpo picado por um inseto; a palavra é um certo lugar de meu mundo linguístico, ela faz parte do meu equipamento, só tenho um meio de representá-la para mim, é pronunciá-la, assim como o artista só tem um meio de representar-se a obra na qual trabalha: é preciso que ele a faça. ${ }^{\prime 55}$

${ }^{53}$ Kosuth, Joseph. "A arte depois da filosofia". op. cit. p. 214.

${ }^{54}$ Essas questões irão reaparecer no interior do capítulo em que a linguagem será discutida no trabalho de Mira Schendel.

55 Merleau-Ponty, Fenomenologia da Percepção. São Paulo: Martins Fontes, 1996. p. 246. 
A palavra não apenas designa um pensamento, ela é de fato a presença do pensamento no mundo sensível, por isso o pensamento não pertence apenas à interioridade do artista ou do pensador, uma vez que o pensamento não existe descolado do mundo ou das palavras. Quando a filosofia é reduzida à análise linguística, a uma positividade, a língua passa a ser vista como transparente, como evidência, como se toda palavra fosse clara e com apenas um único e exato sentido.

A linguagem, entretanto, é inteligibilidade em estado nascente, estrutura aberta que escapa ao instituído. É sincronia e diacronia simultaneamente, um arranjo contingente que permite misteriosamente que as coisas tenham sentido para nós. A linguagem tem o poder de simbolização e por isso é relação com o ausente. Quando o filósofo ou o escritor trabalham não estão apenas dizendo o que já sabiam, mas estão embrenhados no mundo da linguagem. Eles não têm como objetivo o inefável e o intraduzível, mas se eles o expressam é porque do indizível e do invisível surgem o dizível e o visível. É o silêncio que torna possível a expressão e a invenção de novos sentidos.

Segundo Ferreira Gullar:

"A linguagem pictórica, como qualquer outra, só é linguagem porque é sistema e por isso há nela uma natural tendência a fechar-se em seus limites; por outro lado, ela só é linguagem porque é expressão e por isso há também nela uma tendência natural para romper 0 sistema. ${ }^{\prime \prime 2}$.

Para Gullar, no capítulo "O fim da arte", em que defende a arte contra a sua destruição, que só nos empobreceria, as vanguardas em geral destruíram a linguagem artística e, pensando que estavam avançando, estavam na verdade representando um retrocesso. Depois de tudo destruído, o artista passa a ter

${ }^{56}$ Gullar, F. op. cit., p. 72. 
necessidade de formular uma teoria para seu trabalho e, aos poucos, vai substituindo a linguagem visual pela verbal. Segundo Gullar, a partir de uma noção duvidosa de liberdade criadora, a teoria substitui a arte e o conceito toma o lugar da própria obra, entendida como realização objetiva da liberdade. Com a desintegração da linguagem da arte pelas vanguardas históricas, a arte contemporânea, ao eliminar a obra, não teria mais como fundamento a expressão. Para Gullar, isso leva apenas à banalização do trabalho estético, ao efêmero, ao datado e a busca da mera promoção pela mídia.

Entretanto, não foi toda a arte contemporânea que optou pela destruição. Ao contrário, os artistas não cessaram de buscar construir ou reconstruir um trabalho significativo a partir de uma linguagem tanto originária quanto já sedimentada. A expressão não foi completamente descartada. A despeito das generalizações feitas por Gullar acerca de toda e qualquer arte contemporânea, de sua má vontade em abrir-se à arte tal como ela se abre ao mundo, do seu sarcasmo e conservadorismo em relação ao que chamou abstratamente de extravagâncias ou busca apenas pela notícia (argumento que pode ser usado também contra seus textos), certa arte chegou a impasses e aporias que de algum modo podem ser formulados a partir do trabalho de Mira Schendel.

Enquanto Kosuth fala do fim da filosofia e início de uma arte depois da filosofia, autores como Arthur Danto falam inversamente em fim da arte como final de uma história da arte. Se a arte contemporânea não se define mais por nenhuma técnica ou linguagem, e a distinção do que é ou não obra de arte se torna mais complexa, isso implicaria no fim da arte tal como concebida até então e as questões próprias da arte passam para o campo da reflexão e da filosofia. 
Muitas das questões introduzidas aqui serão reencontradas no interior da arte, especificamente no trabalho de Mira Schendel. Durante nosso percurso, iremos retomar diversas das noções tratadas até agora no campo da discussão filosófica sobre o fim da história e da arte. Trata-se, a seguir, de desvendá-las no conjunto da obra de Mira Schendel, nas reflexões feitas pela própria artista e por outros autores sobre ela. Dentro desse complexo panorama, pretendemos investigar certas noções da filosofia que indiretamente, mesmo que dispersas e não sistematizadas, estão presentes ao longo da trajetória da artista. Não se trata de pensar a história da arte como o primeiro capítulo da história da filosofia, mas de discutir as correlações entre filosofia e arte. Para isso, não seria preciso decretar o fim da arte ou o fim da filosofia, uma vez que sendo diferentes elas se reencontram sem que uma precise sucumbir à outra. 


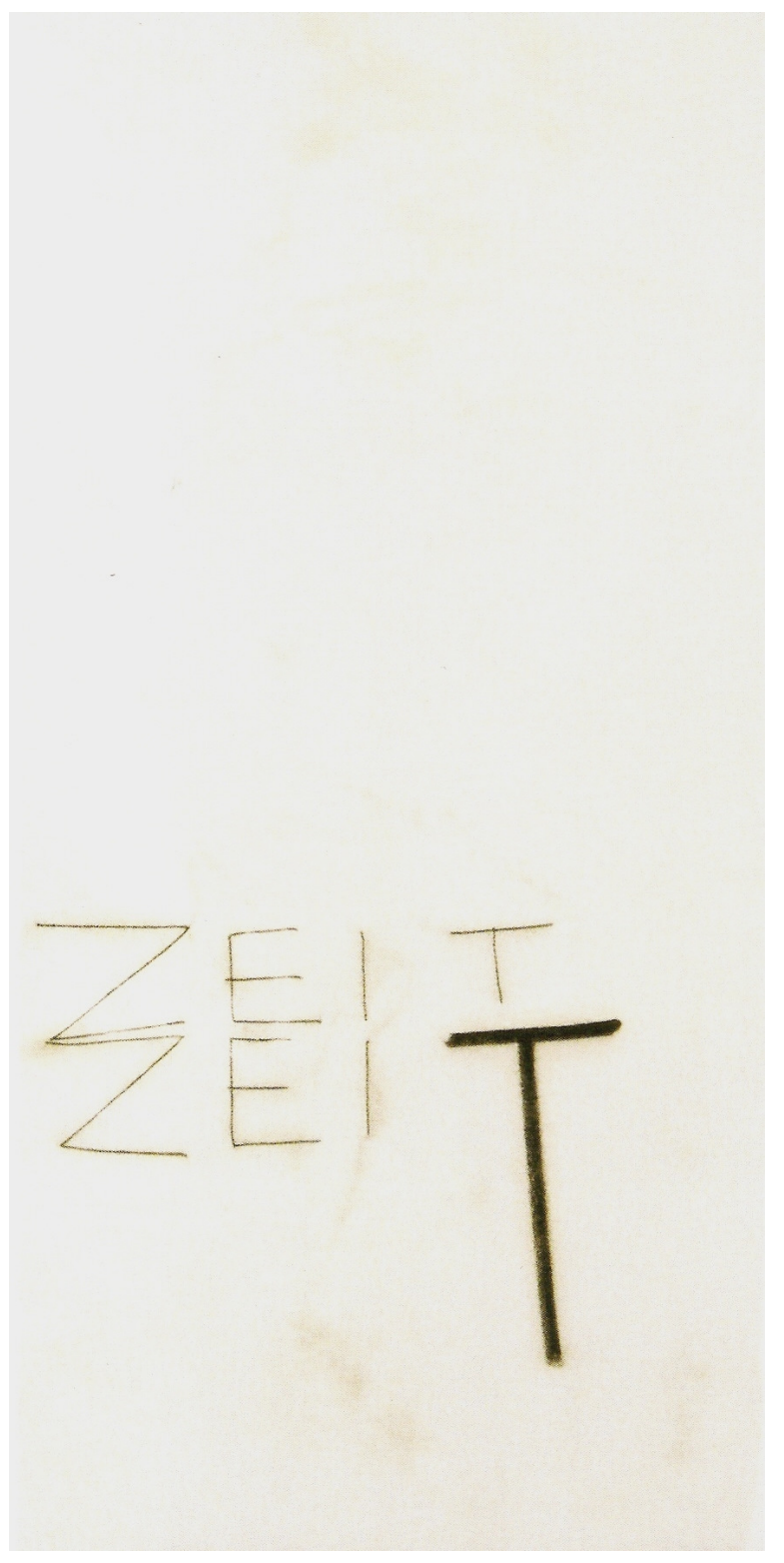

Sem título, 1964-65

Monotipia (óleo sobre papel arroz), $46 \times 23 \mathrm{~cm}$ 


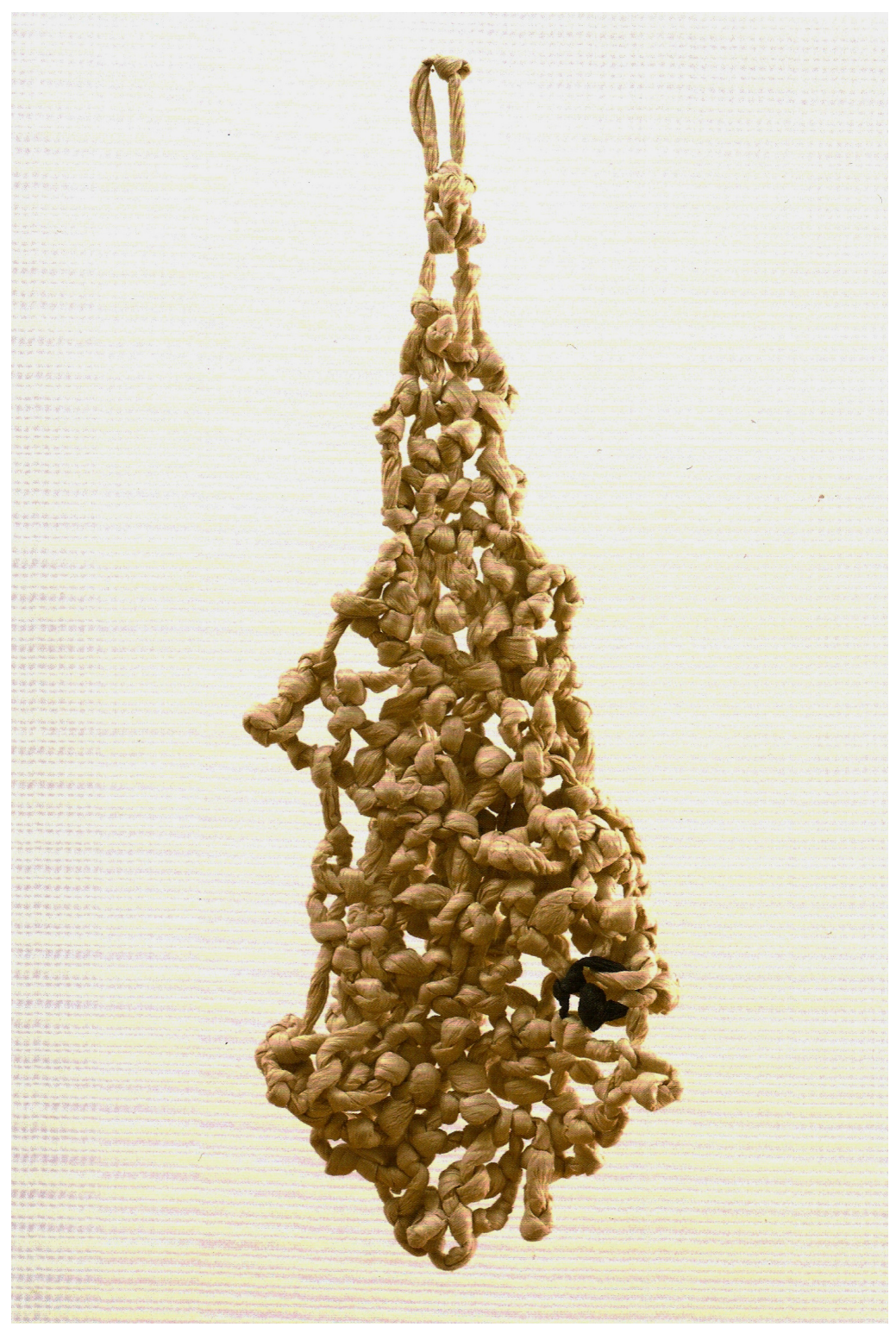

Sem Título (Droguinhas), 1964-66

Papel-arroz, dimensões variáveis

Col. Museum of Modern Art, Nova York 


\section{II. $O$ avesso do avesso}

Vou dar um histórico de como surgiram os objetos que fiz.
Eles surgiram, de certo modo, do acaso e da curiosidade.
Uma vez eu ganhei um papel japonês finíssimo aos
montes. Deixei guardado, não sabendo o que eu poderia
fazer com aquilo. Não tinha nenhuma intenção. [...] Certo
tempo depois - mais ou menos um ano - comecei a
mexer com aquele papel, mas não dava porque ele
rasgava, não aguentava água, não aguentava isso, não
aguentava aquilo. Finíssimo. Aí conheci uma moça que
fazia monotipia e imaginei que, se usasse a técnica da
monotipia - não visando à monotipia, mas simplesmente
pela razão prática de não rasgar o papel cada vez que eu
o manuseasse -, poderia desenhar em cima dele. Fiz
várias experiências e consegui ${ }^{57}$.

Mira Schendel

57 Trecho de depoimento para o Departamento de Pesquisa e Documentação de Arte Brasileira da Fundação Armando Álvares Penteado, São Paulo, 19 de agosto de 1977. 
Embora Mira Schendel não tenha uma produção restrita e especializada em alguma técnica ou suporte, ao contrário, manteve uma atividade experimental durante a maior parte de sua trajetória e investigou uma grande variedade de materiais, pretendemos iniciar a abordagem de sua obra a partir de uma restrita, mas fundamental parte de seu trabalho, os papéis. Para além do juízo de que os papéis constituem a melhor fatia de sua obra, interessanos refletir sobre como esse material foi usado pela artista, os caminhos que a levaram aos objetos e as implicações das opções por diferentes papéis, bem como, a transparência, as relações entre linhas e vazios, frente e verso, interior e exterior em seus trabalhos.

Especialmente no papel-arroz de suas Monotipias - conjunto de aproximadamente dois mil desenhos feitos entre 1964 e 1966 e retomados nos anos de 1970 -, as linhas traçadas por Mira Schendel mais do que instaurar o espaço, o absorvem em sua formação, como se fosse possível agarrá-lo com um gesto. Elas surgem do emprego do corpo em sua totalidade e não apenas da mão ou do cérebro. Talvez por isso ela tenha o poder de despertar o vazio. O espaço vazio de suas monotipias é um misto de desenho e estampa ${ }^{58}$, uma impressão que envolve a atividade intensa e incisiva sobre o papel-arroz e, também, uma passividade do

\footnotetext{
${ }^{58}$ Rodrigo Naves em mais de um texto reforçou o fato de que as monotipias de Mira Schendel devem ser compreendidas antes como desenho do que como um processo de impressão em que se obtêm estampas: "Os desenhos em papel arroz que realizou em meados dos anos 60 - mais de dois mil e ao meu ver equivocadamente identificados como monotipias [...]. Feitos "por trás" - pela ação de uma chave, unha ou grampo sobre as costas do papel arroz posto sobre uma lâmina de vidro entintada -, os desenhos surgem da própria trama do papel poroso, como um material orgânico - fungos, por exemplo - que se confundisse com sua textura." Naves, R. "Mira Schendel: o mundo como generosidade." In: Pérez-Oramas, Luis. Léon Ferrari and Mira Schendel tangled alphabets. New York e São Paulo: Museum of Modern Art/ Cosac Naify, 2009.
} 
suporte que absorve a tinta colocada sobre uma placa de vidro entintada coberta com talco.

Schendel soube aproveitar essa ambiguidade e nela reside uma das dimensões filosóficas de seu trabalho. O vazio de muitas dessas monotipias não se opõe à linha, a marca desenhada por trás, antes são companheiros que dependem um do outro para existirem. Se o papel não é totalmente passivo, porque ele é que entra em contato com a superfície entintada, ele não é apenas suporte, base física que dá sustentação, mas é dele que parte a ação. Portanto, o vazio do papel é um vazio ativo, e a linha em vez de dominar expressivamente o campo em que é traçada é sugada e absorvida por ele. Em carta para Guy Brett de 1965 Schendel escreveu:

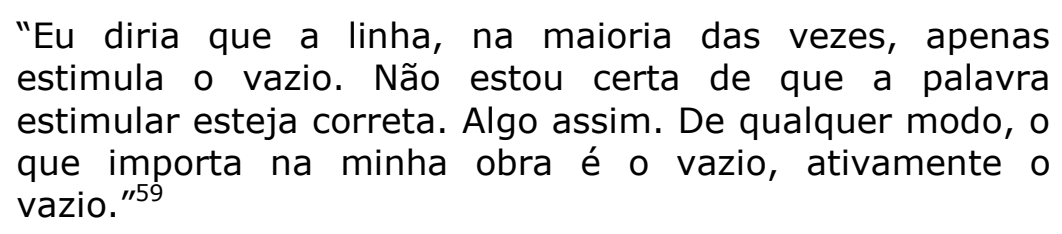

Schendel também escreveu ao crítico inglês que o vazio não é de modo algum substituto do não-ser: "não é símbolo vicário do não-ser." ${ }^{\prime 60} \mathrm{O}$ nada que aparece em seu trabalho possui ligação direta com uma potencialidade de sentido. Guy Brett já havia situado o vazio de Schendel dentro de um antigo dilema filosófico recorrente na arte do pós-guerra como em David Medalla, Yves Klein, Piero Manzoni, Lucio Fontana, Jesús Soto, John Cage, Lygia Clark e Hélio Oiticica, ente outros: "o de que no ato de definir e nomear a realidade acaba-se, de algum modo, por reduzi-la.." ${ }^{161} \mathrm{~A}$ arte dos anos de 1960 e 1970 elaborou de diversos modos o nada,

59 Brett, Guy. "Ativamente o vazio." In: Salzstein, Sônia. No vazio do mundo. São Paulo: Marca d'Água, 1996, p. 50.

${ }^{60}$ Idem, ibidem.

${ }^{61}$ Idem, ibidem. 
o silêncio e o invisível, paradoxalmente, a partir de sons e de materiais visíveis.

"É obviamente paradoxal dar importância ao 'nada', mas esse é o ponto. O vazio consiste sempre numa relação dialética entre uma ausência completa e o seu contrário: potencialidade inesgotável. O silêncio, o vazio, o nada, a negação, podem ser vistos - tanto no sentido filosófico como sócio-político - como um recurso extremamente importante na obra de artistas do pós-guerra, talvez particularmente no Brasil." ${ }^{\prime 62}$

E mesmo que o espaço predominantemente vazio de seus papeis pareça fugidio, afinal ele não pode ser separado da duração, os traços nos desenhos da artista tendem a surpreender o campo em que surgem. O espaço não é apenas um ambiente já dado sobre o qual o trabalho é disposto, um atributo comum a tudo, nem um espaço abstrato, imaginado, no qual os objetos do mundo compartilham propriedades. Há no espaço dos trabalhos de Schendel uma potência de conexão, anterior a distinção entre forma e conteúdo. Mesmo que nas monotipias exista o alto e o baixo, o lado esquerdo e o direito, as linhas do desenho ao atravessarem o papel ancoram o espaço, ou seja, se tornam elas mesmas o suporte, pois é delas que surgem as coordenadas básicas de orientação. Tanto é assim que elas nem sempre são traçadas obedecendo previamente uma noção anterior de frente e verso. A estabilidade do desenho surge dele mesmo, do seu interior - por isso ele é translúcido -, e não de um ambiente já dado. $O$ alto e o baixo, o esquerdo e o direito brotam de exigência interna do trabalho, que nos convida a distinguir os pontos em que o todo está ancorado.

O formato predileto nas monotipias de Schendel é o vertical em que a altura é o dobro da largura, geralmente $46 \times 23 \mathrm{~cm}$. A

${ }^{62}$ Idem, ibidem. 
verticalidade é a mesma do corpo, do nosso corpo, que contribui para a constituição desse espaço, e também é o corpo que recebe essa orientação na experiência que tem no mundo.

Em um só tempo, as linhas da artista dão origem ao espaço e o captam em seu devir, naquilo que ele tem de temporal e passageiro. Suas linhas dividem o papel, definem as relações espaciais e nos fazem vislumbrar letras, figuras abertas, fechadas ou em processo de se formar, sempre indagando a si mesmas e seu entorno.

Segundo a crítica e historiadora da arte Sônia Salzstein:

"A noção da temporalidade, já se disse, está presente em todo o trabalho de Mira Schendel. Nas experiências com materiais efêmeros ela é mais evidente, uma vez que nestas a dimensão temporal aparece de maneira imediata, como ação. Mas em todos os outros objetos aparentemente estáticos criados pela artista há o rumor de uma temporalidade interna. Esta não diz apenas respeito à natureza processual e fenomenológica do trabalho, mas uma espécie de desdobramento transitivo e sem repouso que ele protagoniza." ${ }^{\prime 63}$

O tempo no trabalho de Mira Schendel é este que está sempre na iminência de aparecer, que se apresenta em estado nascente, é pura passagem. Trata-se de um tempo que é qualidade e que, portanto, é aquele que transpassa por dentro as coisas e não apenas corre de instante em instante, numa sucessão que se dá por uma soma de momentos isolados. Schendel se distancia bastante da noção mecânica de tempo que certa arte de matriz geométrica dos anos de 1950 adotou e cujo modelo é a máquina e a regularidade. Também não é o tempo como sucessão de agoras, um tempo que trata o passado e o porvir como presentes, uma noção fundamentada em explicações causais. A sua noção de tempo de modo algum está ligada a uma linha que poderia ser subdivida em intervalos iguais e mensuráveis, ao contrário, trata-

${ }^{63}$ Salzstein, Sônia. op cit., p. 21. 
se de um tempo imensurável e não quantitativo, uma dimensão do nosso ser e que nunca está completamente constituído. Há em seu trabalho um tempo que é fluidez, movimento constante de abertura do porvir e que, portanto, não poderia ser encerrado na idealidade de um conceito.

Em seu diário, Schendel se perguntou, em alguns momentos, sobre a vida atarefada do homem contemporâneo pragmático que, embora tenha quase tudo à mão, como se vivesse num eterno presente, se fecha como se pudesse ter plenos poderes sobre 0 tempo. Se por um lado há uma tentativa de mensuração do modo como se pré-estabelece o futuro, de outro se constata a impossibilidade de apreendê-lo completamente:

\footnotetext{
"Fenomenologicamente: 'não tenho tempo'. Em que medida (isto: medida!) o homem contemporâneo ocupa e pré-ocupa seu tempo, ou seja, noutro termo, em que medida tenta fixar seu futuro. Planejando e evitando (senão fugindo) do 'acaso'. A atitude pragmática é fundamentada na causalidade. Levada ao extremo, não 'deixa ser'. 'Faz'. [...]

Pois um homem que diz não 'ter tempo' pré-ocupou todo o seu tempo. Abriu mão do seu tempo. Fechou-se ao acaso $[\ldots]$ à novidade do novo. ${ }^{\prime \prime 4}$
}

A noção de abertura para o novo e para a indeterminação do acaso é fundamental para compreendermos muitos dos seus trabalhos. Já na série Bordados, 1962-1964, desenhos em papelarroz com motivos geométricos em que a noção de manualidade é evidente, ou mesmo na série Bombas, que apresenta composição geométrica feitas de pinceladas realizadas com uma brocha larga sobre papéis umedecidos, cheia de borrões e sem nenhuma rigidez, as formas insinuam movimentos que escapam ao domínio pleno do gesto, uma espontaneidade que propaga no papel como ondas que se quebram na praia.

${ }^{64}$ Schendel, M. Diário inédito, sem data. 
É como se os trabalhos fossem resultados de micro-explosões ou de fissões nucleares que liberam grande energia que se espalha para além dos limites do contato do pincel com o papel. Nesse processo o pigmento vai se diferenciando de si mesmo sem se separar de si. Os contornos borrados, um tanto líquidos e esfumaçados da tinta não são apenas vestígios de um gesto, mas também rastros de um espaço que se desloca, um espaço ativo, um campo onde o tempo está infiltrado e que, portanto, não é apenas espaço quantitativo. É como se o papel aquoso que tudo absorve tornasse os limites indefinidos, as massas irregulares, com várias gradações de preto, que se diferenciam de acordo com a densidade da tinta. As diferenças de concentração de preto entre o centro e a borda revelam o pouco controle que ela possui sobre o nanquim que se esparrama em várias direções.

O crítico e historiador da arte Rodrigo Naves já havia chamado atenção para essa falta de controle que outra série, a das Monotipias, implicava. A técnica de desenhar sobre uma placa de vidro entintada e coberta com talco pressupunha uma mediação entre o desenho e o papel:

\begin{abstract}
"A meu ver era justamente essa diminuição do controle sobre o desenho que interessava a Mira Schendel. Era daí que seu trabalho tirava uma intensidade toda particular, proveniente não tanto de uma presença marcada da linha, e sim de seu estranhamento com o papel. ${ }^{165}$
\end{abstract}

Por isso, a técnica que Mira Schendel usa é quase uma não técnica, já que se afasta de um conjunto de procedimentos com o intuito de produzir algo já determinado anteriormente. Técnica, para ela, não se confunde com virtuosismo, com habilidade ou controle dos instrumentos e materiais, ao contrário, é vivência, é gesto imediato e aberto ao acaso. A monotipia, por exemplo, é uma espécie de mediação para evitar que o papel seja rasgado, mas quando

${ }^{65}$ Naves, Rodrigo. "Pelas Costas", em Salzstein, Sônia. op. cit., p. 63. 
acontece algum acidente ou imprevisto ele é completamente incorporado ao trabalho final, revelando que o gesto vai além do premeditado. É como se cada movimento seu fosse o primeiro, sempre se descobrindo e se reinventando. E essa sabedoria de sua obra foi conquistada depois de muito exercício e não sem boa dose de disciplina.

A artista sempre soube explorar a materialidade do papel e jamais encobriu ou tentou dissimular sua presença. A transparência dos papeis nunca poderia ser compreendida como análoga de uma consciência que se pretenda interioridade plena, transparência de si consigo mesma. A transparência dos papéis parece ser continuidade de sua relação com o seu entorno.

Schendel soube estabelecer uma rica relação entre o ar, a atmosfera ao redor, as transparências e a leveza do corpo do papel, como nos Trenzinhos em que qualquer brisa provoca movimentos sutis nas folhas soltas penduradas num fio de nylon. 0 fio atravessa uma série de folhas alinhadas unificando-as num fluxo contínuo. Transpassando o papel por dentro, o fio mimetiza o movimento da luz que também penetra e percorre a espessura de cada uma das finas folhas de papel-arroz. O próprio título Trenzinho pressupõe o enfileiramento de vagões engatados ou a imagem de um comboio. Entretanto, o trabalho está distante da já desgastada metáfora moderna do trem e da máquina como símbolo do progresso industrial ou do ideário desenvolvimentista de uma metrópole barulhenta que não para de crescer. O diminutivo do título nos afasta da força de uma grande locomotiva para nos revelar silenciosamente a continuidade do movimento da linha que arremata os papéis como o fio de um colar de pérolas ou o trilho em relação ao trem.

A matéria nos trabalhos de Schendel feitos com papel possui algo de essencial, de mínimo, mas que não se opõe a sua 
aparência física. Mesmo porque não seria possível que a matéria se opusesse a alguma suposta essência ou substância ideal do trabalho.

O filósofo Merleau-Ponty em o visível e o invisível, livro inacabado em que desenvolve sua pesquisa sobre a tentativa de superação do dualismo clássico, já falava de um corpo menos pesado e transparente que a idealidade talvez pudesse habitar:

\begin{abstract}
"Dizemos somente que a idealidade pura não existe sem carne nem liberta das estruturas do horizonte: vive delas, embora se trate de outra carne e de outros horizontes. E como se a visibilidade que anima o mundo sensível emigrasse, não para fora do corpo, mas para outro corpo menos pesado, mais transparente, como se mudasse de carne, abandonando a do corpo da linguagem, e assim se libertasse de toda condição." ${ }^{\prime \prime 6}$
\end{abstract}

Esse fragmento de texto de Merleau-Ponty, deslocado de seu contexto original, poderia muito bem ter sido escrito em relação ao trabalho de Schendel, uma vez que há nele um pensamento que surge de dentro da matéria, um invisível que sustenta por dentro esse corpo menos pesado e transparente que são os papéis de seus desenhos.

Se por um lado os Trenzinhos já foram confundidos com algum objeto de arte conceitual ou apenas como objetos sem qualquer significação, como se não fossem indícios de um gesto artístico, eles também são capazes de abrirem significações e sentidos em quem os percebe, em gerar uma posteridade e um impensado, aquilo que não foi vislumbrado pela artista, mas que sua obra suscita e faz pensar. Não há relação de exterioridade entre sua ação e o trabalho, entre seu mundo interior e o exterior, entre gesto e símbolo ou entre frente e verso em seus papéis.

Aos poucos, principalmente nas Droguinhas (folhas de papelarroz retorcidas e trançadas), mas também na série Toquinhos

${ }^{66}$ Merleau-Ponty, O visível e o invisível, São Paulo: Perspectiva, 2000, p. 147. 
(papel artesanal tingido e colado sobre outras folhas), o trabalho de Schendel ganha maior consistência física, adquire um corpo mais sólido e passa a ter uma presença mais firme no espaço tridimensional. O papel vai se transmutando ao longo da trajetória da artista e se articulando de diversas maneiras durante a década de 1960. A superfície se torna transparência e esta, a partir do Trenzinho, vira fluxo contínuo, que ganha corpo e solidez ao ser retorcido e entrelaçado nas Droguinhas.

A corporificação ocorre mesmo que as Droguinhas se aproximem de resíduos de papel-arroz e por isso tenham algo de efêmero e provisório. A noção de corpo, com toda a ambiguidade de ser frágil e sólido, permanente e descartável ${ }^{67}$, de ser matérico e espiritual, simultaneamente, poderá ser aproximada de certas questões filosóficas que inquietavam a artista.

Segundo os próprios escritos de Schendel, é do corpo ligado à fenomenologia que seus trabalhos se aproximam. Por volta de 1936, residindo em Milão, a artista frequentou escola de arte, e em seguida, durante dois anos, cursou filosofia na Universidade Católica. Nos anos de 1970, depois de ter se transferido para São Paulo, SP, trocou correspondência com o filósofo alemão Hermann Schmitz e inclusive chegou a visitá-lo algumas vezes na Alemanha nos anos de 1970 .

Em debate realizado em 1975, por ocasião do X Salão de Arte Contemporânea de Campinas, SP, a artista citou o filósofo:

\footnotetext{
67 Segundo Guy Brett as Droguinhas eram no momento em que foram concebidas completamente invendáveis para Mira Schendel. "Podiam ser colocadas numa caixa para a proteção, mas fazer isso seria 'como guardar a espuma de Davis Medalla' (referindo-se às efervescentes Máquinas de Borbulhas de meados da década de sessenta)." Há uma frase da artista escrita ao crítico que de fato contrasta com a sua absorção atual pelo mercado ou pelas instituições, indício de sua relevância para o público contemporâneo: "Quem quer que as 'possua' não as deixará 'ser'. A eternidade da flor e a eternidade da basílica românica. A essência (e.g., em Husserl) e a duração." Brett, Guy. op. cit., p. 55.
} 
"Pelo que sei, coube a Hermann Schimitz, da Universidade de Kiel, a imensa tarefa de sistematizar dados oferecidos por várias disciplinas e elaborar uma fenomenologia que, diferente da do velho estilo (Husserl, Scheler, Heidegger, Sartre), não seja vítima da exigência de complementação metafísica. Uma nova fenomenologia cuja peça central é dada pela corporeidade ${ }^{\prime 68}$.

Apesar desse pronunciamento de Schendel, não poderíamos tratar sua obra seja apenas uma ilustração da filosofia. Jamais seria possível dizer que seu trabalho é um comentário da filosofia ou tampouco uma tradução visual de conceitos. Nesse sentido, esta questão se problematiza, pois, como aponta Sônia Salzstein:

"[...] não há nada parecido a um discurso filosófico na
obra de Mira. As preocupações 'filosóficas' que interessam
a artista parecem provir de uma rebeldia perante a vida,
de sorte que o problema sujeito/ objeto apresenta-se aí
antes de mais nada como a consulta que o indivíduo faz
ao 'vazio do mundo' sobre o lugar que nele cabe
ocupar." 69

No caso do presente trabalho, pretende-se entender também as preocupações filosóficas da artista a partir de sua interlocução com diversos pensadores, da rede de relações filosóficas que perpassam sua obra, bem como buscar no trabalho de Schendel pistas ou indícios dessa rebeldia perante a vida. Sem qualquer intenção de fazer filosofia, mas sempre indagando a si mesma e ao mundo, o trabalho de Schendel torna-se ainda mais instigante se compreendido sob essa perspectiva da consulta que a artista de fato faz ao "vazio do mundo". É justamente do vazio que ela vai fazer brotar uma obra abundante.

A noção de corporeidade, de um corpo reflexivo, que dissolve a separação entre atividade e passividade, como vimos em relação às monotipias e iremos desenvolver mais a frente, é fundamental no trabalho de Mira Schendel. O corpo que seus trabalhos

\footnotetext{
${ }^{68}$ Schendel, Mira. in: Salzstein, Sônia. "No vazio do mundo", op. cit., p. 94.

${ }^{69}$ Salzstein, Sônia. "No vazio do mundo", op. cit., p 16.
} 
adquirem não apenas ocupa o espaço, mas o ativa e se vale para isso de vazios e intervalos. A relação que seu trabalho estabelece com o sujeito que o contempla, convidado a circular ao redor dele, permite que o público inspire e aspire o mesmo ar que é constituinte das peças.

Coincidentemente, Merleau-Ponty, em "O olho e o espírito", já havia escrito em 1960:

"Isso a que se chama inspiração deveria ser tomado ao pé da letra: há deveras inspiração e expiração do Ser, respiração no Ser, ação e paixão tão pouco discerníveis, que já não se sabe mais quem vê e quem é visto, quem pinta e quem é pintado." 70

Essa reversibilidade entre sujeito e objeto, entre dentro e fora, entre interioridade e exterioridade, que de modo algum implicaria num discurso filosófico da artista, mesmo porque ela irá resistir a compreensão de que haveria uma metafísica implícita em eu trabalho, é relevante, entretanto, para a compreensão de seu trabalho.

Como mostram suas correspondências, a artista se interessou bastante por conversas com filósofos como Hermann Schmitz ${ }^{71}$ sobre a superação do dualismo clássico entre corpo e alma ou entre objetivo e subjetivo.

Inseparável do mundo sensível e, portanto, apenas apreensível pelos sentidos, o que jamais implicaria numa recusa do campo do pensamento, seu trabalho é também um sensível para si mesmo, ele é um corpo sensível e senciente, ou seja, se comporta simultaneamente como ativo e passivo. Quem o percebe não é apenas um receptor, mas alguém que simultaneamente pode agir

\footnotetext{
${ }^{70}$ Merleau-Ponty, M. Textos Escolhidos. São Paulo, Abril Cultural, 1975. (Coleção Os Pensadores). p. 282.

${ }^{71}$ Conferir entrevista com Hermann Schmitz realizada por Geraldo Souza Dias e publicada na revista Novos Estudos, n. 74, São Paulo, CEBRAP, março de 2006, p 141-153.
} 
sobre o trabalho a partir de uma percepção criadora. O trabalho, do mesmo modo, não é inerte no sentido de ser apenas um objeto que recebe sentidos exteriores de um sujeito, ao contrário, também age sobre o corpo de quem o percebe. Atividade e passividade são indiscerníveis e simultâneas.

Os desenhos de Mira Schendel nos dão acesso ao que Merleau-Ponty chama de "ser de indivisão", anterior às separações entre corpo e espírito ou entre significante e significado. Se ainda há algum sentido metafísico nos papéis de Mira Schendel evidentemente não é aquele da antiga metafísica de origem platônica, que opunha a essência e a aparência, e sim da metafísica que está silenciosa e invisivelmente pressuposta na percepção e na linguagem, e que assim entendida fundamenta a tentativa de superação do subjetivo e objetivo como alternativas clássicas. É justamente essa metafísica que pressupõe uma espécie de céu, onde estariam os sentidos e as essências que sustentam o mundo das aparências, que chega ao fim. É a ela que a noção de corporeidade parece responder.

O gesto de Schendel, ao traçar linhas sobre um plano translúcido, desfaz a oposição entre um espaço opaco, interior ao papel, e a superfície, que seria pura exterioridade. Suas linhas, além de possuírem duração no tempo, parecem ter a consciência de sua duração e por isso estabelecem uma relação tão franca com a matéria e o espaço bi ou tridimensional.

A chegada de Mira Schendel ao objeto, como em Droguinhas, mas também nos seus Objetos gráficos, papéis prensados entre placas de acrílico $^{72}$ e pendurados por fios de nylon transparentes

\footnotetext{
72 Em entrevista a Jorge Guinle Filho a artista nos conta: "Aqui [...] há o problema da transparência, do dentro e do fora, o dentro e o fora ao mesmo tempo, como objeto e sujeito são os mesmos, o côncavo e o convexo são juntos, sente-se assim a temática da transparência." In "Mira Schendel, pintora", Interview, São Paulo, jul. 1981, p. 54.
} 
realiza uma conquista em que definitivamente o problema entre 0 dentro e o fora, o côncavo e o convexo se resolvem pela transparência do material. Com o acrílico as duas faces, os dois planos, frente e verso se tornam visíveis. O texto visto ao contrário, invertido como numa matriz, camuflado pela reversão, se torna antes imagem do que sentido e, em seguida, o sentido parece tão evidente que é como se a imagem se diluísse. Toda a obra surge de uma ação de trabalhar pelo avesso, de tecer por trás.

Merleau-Ponty já havia percebido que "como o tecelão, o escritor trabalha pelo avesso: lida apenas com a linguagem, e é assim que de repente se encontra rodeado de sentido." ${ }^{\prime 73}$ Embora não seja propriamente uma escritora, Mira Schendel captura as palavras antes que elas possam fugir, e por vezes as retorcendo de tal modo que é como se elas pudessem dizer algo que não estava previsto em seu sentido vernacular. É como se ela virasse as palavras pelo avesso, mas no caso de Schendel trata-se de um avesso que não se opõe ao direito, na experiência perceptível eles são indiscerníveis, um atrás que é simultaneamente frente, é avesso do avesso.

73 Merleau-Ponty, M. "A linguagem indireta e as vozes do silêncio". O olho e o espírito. São Paulo: Cosac Naify, 2004. p. 73-74. 


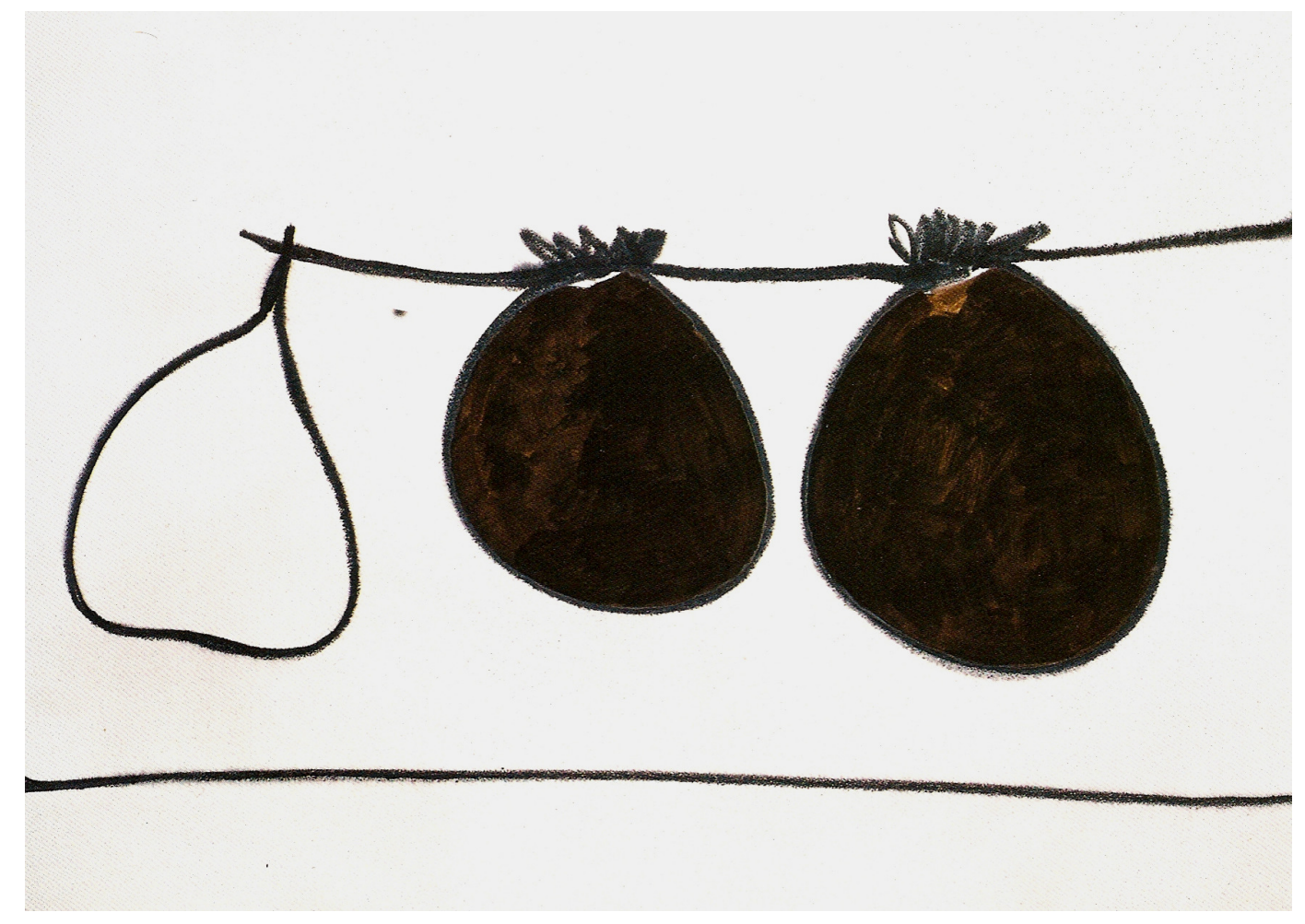

Sem Título, 1983

Técnica mista sobre papel, $54,5 \times 75 \mathrm{~cm}$ 


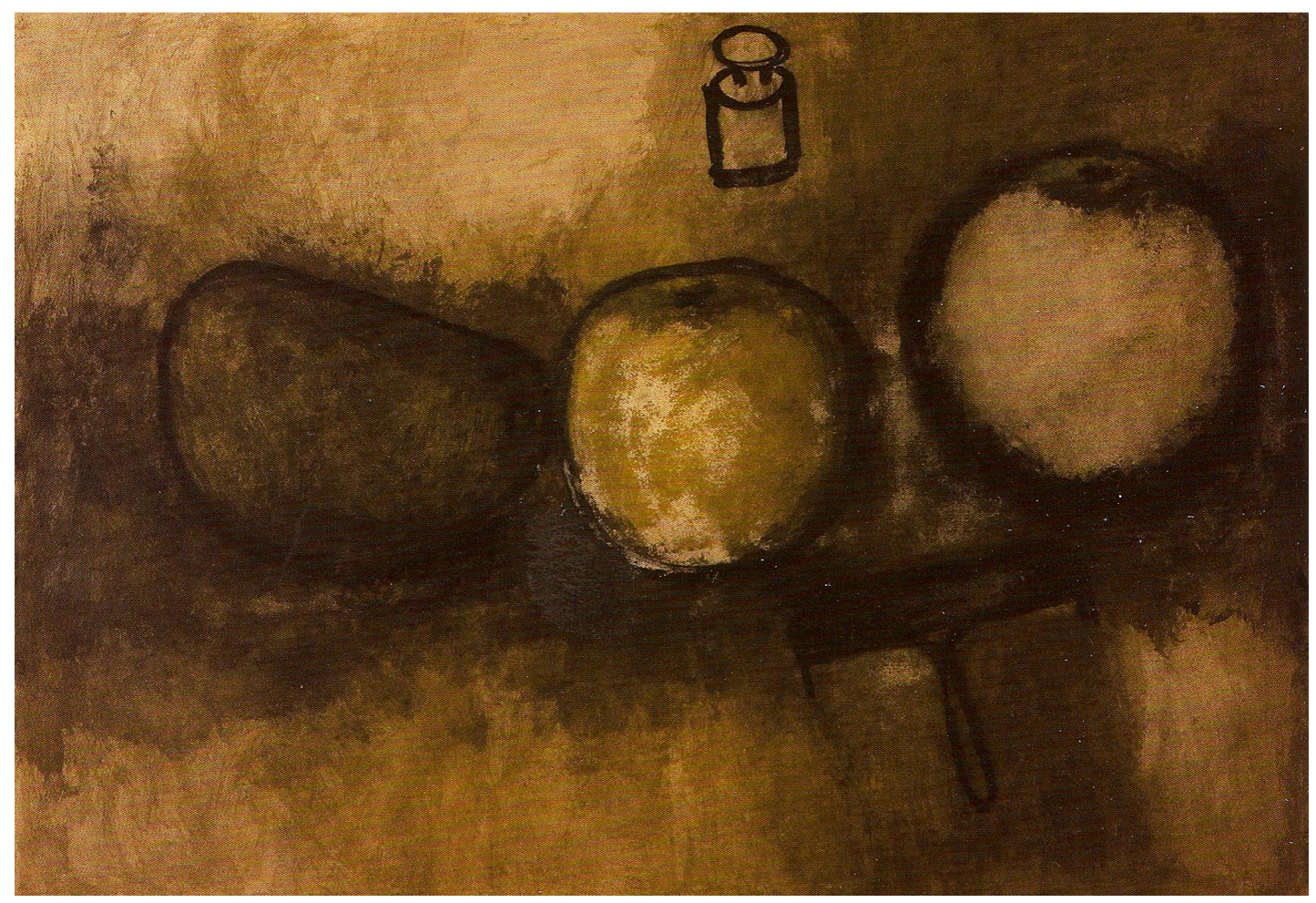

Sem Título, 1964

Têmpera sobre papel, $45 \times 66 \mathrm{~cm}$ 


\section{Arte e metafísica}

"Posso superar o dualismo, mas não o posso aniquilar." Mira Schendel ${ }^{74}$

Filha de judeus, a vida de Mira Schendel foi marcada tanto pela fuga do fascismo quanto pelo antissemitismo. Myrrha Dagmar Dub, seu nome de registro, nasceu em Zurique em 1919 e devido a uma série de restrições para a permanência de judeus na Suíça, com menos de um ano de idade se transferiu com seu pai Karl Dub e sua mãe Ada Saveria, para Berlim, onde viveu por pouquíssimo

${ }^{74}$ Schendel. Diário inédito. 
tempo. Depois da separação de seus pais, cresceu na Itália, onde recebeu educação católica, mas manteve na infância contato próximo com a família do pai na Boêmia e também com a língua alemã e o judaísmo. Durante a Segunda Guerra, devido a sua ascendência judia, foi expulsa da Itália e teve que abandonar seus estudos em filosofia na Università Cattolica del Sacro Cuore, que havia começado dois anos antes. Em 1941, refugiou-se na Bulgária e em seguida foi para a Iugoslávia. Nesse mesmo ano, em Saravejo, casou-se com Jossip Hargesheimer, croata católico, e depois de retornar para a Itália o casal Hargesheimer emigrou para o Brasil em 1949, fixando-se em Porto Alegre.

No início de 1950, assinando como Mira Hargesheimer, publicou uma carta aberta na capa do Correio do Povo, com direito a uma foto, sobre a complicada situação dos deslocados de guerra, onde denunciou o sofrimento e as hostilidades vividas pelos imigrantes no Brasil:

\begin{abstract}
"Levantar-se-á dentre o povo brasileiro uma voz que compreenda nossa Angústia? Desejará alguém compartilhar de nossa dor? Até o momento, os 'direitos do homem', enfaticamente proclamados nas assembléias nacionais dos países que se erigem em defensores da liberdade e da justiça, foram pelos mesmos espesinhados todas as vezes em que se tratou de abordar, quando muito, os mais modestos aspectos que a nós diziam respeito. ${ }^{\prime 75}$
\end{abstract}

Esse seu contundente e raro posicionamento político reverberou na imprensa local da época, com uma resposta publicada por um dos redatores do jornal e com uma réplica em forma de segunda carta, "Imigrantes de hoje e brasileiros de amanhã ${ }^{76}$, publicada pela artista na semana seguinte, onde ela

\footnotetext{
75 Hargesheimer, Mira. "O drama dos emigrantes europeus", Correio do Povo, Porto Alegre, 7 de Janeiro de 1950.

${ }^{76}$ Texto publicado no Correio do Povo, Porto Alegre, 15 de Janeiro de 1950.
} 
distinguiu o que ocorreu com os "velhos imigrantes" do que se passou com a nova leva, da qual faz parte.

O mesmo jornal já havia reconhecido a solidez de formação de Mira Hargesheimer, que havia chegado a Porto Alegre com mais de trinta anos de idade, e deu uma nota sobre a exposição da "artista jovem e de arejado talento", no auditório do Correio do Povo, o único lugar para se mostrar arte moderna na cidade. Em outubro de 1950, também foi publicada uma resenha de Aldo Obino ${ }^{77}$, sobre a "pintora italiana" que apresentou uma série de desenhos e pinturas sombrias, melancólicas e classificadas genericamente de vanguardistas pela imprensa.

Nesse período sua obra possui algo da "pintura metafísica" de Giorgio Morandi, que provavelmente conheceu ainda na Itália e que com certeza viu de perto no Museu de Arte Moderna de São Paulo, em 1953, ano em que se separou e transferiu definitivamente para a capital paulista. Em 1951, ela já havia exposto suas "pinturas metafísicas" na $1^{\text {a }}$ Bienal Internacional de São Paulo.

A arte metafísica é tradicionalmente associada à pintura de Morandi e principalmente de De Chirico, que representa cenas enigmáticas e com elementos da arquitetura clássica, como se fosse uma arte para além do presente e fora da história. A noção de metafísica da arte italiana está ligada à transcendência da temporalidade e da realidade ${ }^{78}$. Morandi, embora tenha uma trajetória isolada, participou durante a década de 1920 na Itália da scuola metafísica e produziu uma série de naturezas-mortas admiradas por Schendel. Além das aproximações afetivas entre objetos cotidianos como garrafas ou vasos, Morandi dá a eles uma

\footnotetext{
77 Obino, Aldo. "Pintora italiana que surge". Correio do Povo, Porto Alegre, 17 de Outubro de 1950.

78 Será da ideia de metafísica como transcendência que o trabalho de Schendel irá se distanciar. É a metafísica como transcendência que ela se refere quando afirma que a nova fenomenologia não depende da "exigência de complementação metafísica".
} 
ideia de permanência. É como se os objetos modificassem completamente o espaço em que estão representados, um espaço que possui sutis transparências e velaturas. Cobertos por uma luz cinzenta, uma atmosfera meditativa e silenciosa, os objetos pintados por Morandi, por mais concretos que sejam, acabam aludindo a uma realidade para além daquela que nossos olhos podem perceber. Trata-se de uma presença que se dá nos intervalos e nas relações com seu entorno. O vínculo entre as formas fica mais difuso, menos marcado e com os limites quase borrados.

Segundo Rodrigo Naves a pintura de Morandi exerceu uma influência decisiva, não apenas em Mira Schendel, mas em parte considerável da arte brasileira, de Alfredo Volpi a Iberê Camargo, passando por Amilcar de Castro até pintores contemporâneos como Paulo Pasta:

\begin{abstract}
"Contudo, acredito que não estaríamos longe da verdade se víssemos nessa atração pelo sábio tonalismo morandiano um vínculo muito profundo com certos aspectos decisivos de nossa sociabilidade. Da ausência de grandes rupturas sociais à busca de uma convivência fraterna e pessoal, muitos traços decisivos de nossa sociabilidade e da cultura brasileiras parecem depositar suas esperanças em vínculos mais pessoais, nos quais relações afetivas e alheias às normas universais garantiriam uma defesa contra a impessoalidade das instituições $[\ldots] .{ }^{\prime \prime 79}$
\end{abstract}

Seriam justamente esses vínculos afetivos e pessoais entre os diferentes elementos da pintura tonal que permitiriam a superação da violência do convívio social brasileiro. Mas se por um lado sua pintura sem grandes contrastes do período estabelecia uma relação íntima entre objetos diferentes, por outro ela se diferencia da contundência do texto sobre o drama do imigrante

79 Naves, Rodrigo. "Mira Schendel, o mundo como generosidade". $\underline{\text { OESP, }} 29$ de Março de 2009. 
que a artista publicara na imprensa. Entretanto, sua segunda carta ao Correio do Povo corrobora os argumentos de Naves. Nela, Mira menciona o "espírito de fraternidade" do povo brasileiro e uma suposta ausência de preconceitos da sociedade brasileira:

\footnotetext{
"Pessoalmente considero ser uma inesperada ventura poder viver entre um povo que [...] trabalha sem preconceitos de nacionalidade, de raça, de cor ou de religião. Não haveria motivo para nenhuma profecia de êxito se este povo não fizesse - como efetivamente está fazendo - do seu país um campo desmedidamente aberto às pacíficas conquistas humanas. ${ }^{180}$
}

A aproximação de cores por uma luminosidade homogênea que permite uma transição suave entre diferentes elementos ou massas de cor irá se manifestar também em algumas das suas pinturas dos anos de 1960. Mas ao longo de sua trajetória, a artista abandonará o tonalismo, assim como algo da metafísica morandiana. Ao superar problemas compositivos, dirigir-se ao espaço concreto e ganhar corpo, a pintura de Schendel se torna matérica e monocromática. A última série de pinturas que a artista fez, é composta por um elemento pesado, denso e opaco como o pó de tijolo, em que uma luminosidade difusa e amena do início de sua trajetória retorna.

A pintura de Mira Schendel vai se transformando bastante desde o final de 1940, início de 1950, até a década de oitenta. Além de óleos sobre tela de tendência metafísica do início, há uma série de naturezas-mortas feitas em papel e nanquim, com aparência mais aguada e lisa; os trabalhos em têmpera sobre madeira, mais construtivos; pinturas em que ela escreve frases, até as obras mais espessas, com superfícies irregulares, onde são usados materiais como areia, gesso e argila, e que possuem uma

\footnotetext{
${ }^{80}$ Hargesheimer, Mira. "Imigrantes de hoje e brasileiros de amanhã" Correio do Povo, Porto Alegre, 15 de Janeiro de 1950.
} 
presença mais encorpada. Outras ainda, realizadas sobre juta com densas camadas de tinta, deixam a trama larga do tecido exposta. A espacialidade desses trabalhos é em alguns momentos reforçada quando Schendel recorta retângulos que acentuam o vazado da trama e permitem que nosso olhar atravesse completamente 0 plano da tela, momento em que definitivamente sua pintura se distancia de qualquer metafísica das essências para habitar o mesmo espaço que o corpo do observador.

Mário Schenberg já havia notado, em texto de 1964, as grandes transformações pelas quais a pintura de Schendel havia passado. Sem perder sua autenticidade ou romper com o "espírito essencial de sua obra", ela soube desenvolver e modificar seu trabalho a partir de "numerosas vivências e experiências artísticas $^{\prime 81}$.

Esse é o próprio sentido da verdadeira liberdade, que segundo Merleau-Ponty, "só pode existir no percurso da vida, pela superação da situação de partida e sem que deixemos, contudo, de ser o mesmo". ${ }^{82}$ Se por um lado não há nada que determine as mudanças no curso da nossa vida, por outro poderíamos dizer que somos sempre os mesmos, não mudamos nunca, uma vez que a rigor poderíamos sempre encontrar o prenúncio de qualquer evento presente no passado: "Cabe-nos entender as duas coisas ao mesmo tempo e como a liberdade irrompe em nós sem romper nossos elos com o mundo" ${ }^{83}$, escreve o filósofo.

O aspecto mutante, bem como os dilemas e incertezas de Mira Schendel, eram conhecidos pelos seus interlocutores da época. Em carta escrita por seu amigo Ely José Andreazza, médico

${ }^{81}$ Schenberg, Mário. Texto publicado no catálogo da exposição individual de Mira Schendel na Galeria Astréia, em São Paulo, 1964.

82 Merleau-Ponty. "A dúvida de Cézanne" in: Textos Escolhidos. op. cit. p. 313.

${ }^{83}$ Idem, ibidem. 
de descendência italiana com quem manteve correspondência, Mira Schendel é descrita do seguinte modo:

\begin{abstract}
"Tua bondade para com o indivíduo é uma espécie de negação desta virtude, não manténs por muito tempo um conceito num estado, daí necessitares de pactos, de definições que formem, que alicercem tuas certezas. [...] perdeste a confiança em todos, duvídas sempre, estás insegura. ${ }^{184}$
\end{abstract}

O trabalho de Mira Schendel no início dos anos de 1950 foi realizado praticamente na solidão completa. Uma obra que foi construída sem grandes interlocutores que a artista valorizasse e, portanto, sem possibilidade de influência externa ou de diálogo com críticos relevantes, segundo a artista. Esse ambiente hostil também estimulou sua mudança para São Paulo, onde irá criar uma grande rede de interlocutores. Em sua chegada, a artista conta do prazer de visitar a Biblioteca Municipal, cujo então diretor era Sérgio Milliet, onde pode ver boas reproduções de obras de arte, ocasião que constatou que lá "existem os mais importantes livros de Husserl." 85

Nesse período é que sua obra começa a passar por profundas modificações. E também por conta de sua insatisfação com o trabalho ela não participaria da $2^{a}$ Bienal Internacional de São Paulo, uma das mais importantes edições do evento. O pesquisador Geraldo de Souza Dias transcreveu algumas cartas da artista endereçadas para Arno, também chamado de Vauco e sobre o qual não se tem muita informação, datadas de 1953, em que ela demonstra oscilação entre a auto-confiança e insatisfação:

\footnotetext{
${ }^{84}$ Andreazza, Ely José. Carta a Mira, Porto Alegre, 24 de outubro de 1951.

${ }^{85}$ Texto sem data encontrado no arquivo da artista.
} 
"A minha pintura está numa dificílima fase de transição, terei que lutar muito até encontrar um caminho certo." ${ }^{\prime \prime 6}$

"Acerca de minhas pinturas ando mais ou menos desesperada. Nem queria apresentar os trabalhos para a Bienal. Primeiro porque me julgo absolutamente despreparada e segundo porque somente uns $10 \%$ serão admitidos. Queria pintar anos sem que ninguém, fora de ti, visse o que faço. Estudar o ofício ou deixar por completo. Porque enfim melhor seria estudar e trabalhar por dinheiro que perder tempo com uma coisa impossível. Talvez tu nem saibas que esforço é para mim tudo isso. Penso nestes dias, a luta para pintar..." ${ }^{\prime 87}$

"Acho que no início da semana entrante iniciarei uma nova tela, talvez abstrata. Penso muito em pintura e duvido muitíssimo de chegar a tornar-me boa." ${ }^{188}$

"Não posso compreender o que há comigo em relação a isso - logo ao chegar iniciei os dois trabalhos que sabes. Estão acabados, queria pintar e estou numa crise medonha. Provocada não sei se pelo que vi ou por falta de calma. Claro que as palavras de Hoeltje [Georg Hoeltje, historiador de arte que ministrou palestra sobre Aleijadinho no MAM] não me ajudariam muito, inútil dizer que ele não é crítico de arte, mas Kunsthistoriker [historiador da arte]. Nada adianta nesse momento. ${ }^{189}$

Essa incerteza em relação ao seu trabalho, assim como sua solidão, poderia ser comparada com a dúvida de Cézanne, tal como ela nos é apresentada por Merleau-Ponty. Embora Mira Schendel não indague como o pintor francês se sua pintura estaria assentada em um defeito do corpo ou num distúrbio visual, guardada as devidas proporções, ela também teve em Porto Alegre uma recepção negativa como muitas das críticas recebidas por Cézanne pelos seus contemporâneos como Émile Bernard e Zola. Schendel chegou inclusive a escrever para parentes, ainda no período de Porto Alegre, que "agora tenho todos os colegas daqui contra mim, isso talvez signifique que seria ótima coisa mudar de ares", e em

\footnotetext{
${ }^{86}$ Hargesheimer, Mira. Carta para Vauco, São Paulo, 23 de Julho 1953, publicada em: Dias, Geraldo Souza. Mira Schendel: do espiritual à corporeidade. São Paulo: Cosac Naify, 2009, p. 49.

${ }^{87}$ Idem, ibidem.

${ }^{88}$ Idem, ibidem.

${ }^{89}$ Idem, ibidem.
} 
seguida demonstrando completa segurança prossegue, "ou talvez signifique que agora necessite de livre concorrência. Não ter concorrentes sérios não dá prazer algum. ${ }^{\prime 90}$ Mesmo sem o apoio do meio, ou seja, dos que poderiam conferir valor ao seu trabalho e duvidando de si mesma, a artista não deixou de pintar. Embora obrigada a largar o curso de arte que iniciou em Milão, não pode parar de pintar.

Haroldo de Campos, poeta e tradutor com quem teve contato a partir de Mário Schenberg, também havia percebido o relativo isolamento da artista, uma certa sensação de exílio que ela tinha e uma espécie de frustração devido a falta de uma calorosa recepção ainda em vida. Segundo Haroldo de Campos:

\footnotetext{
"A obra dela tinha realmente uma dimensão de futuro que ela mesma não via, da qual não suspeitava, preocupada que estava com a condição de comunicação imediata, vivendo muito isoladamente, não participando do mundo artístico, não sendo uma pessoa mundana. Era profundamente preocupada com questões existenciais. Fazia muitas leituras fenomenológicas $[\ldots]^{191}$
}

A questão que surge é semelhante à colocada por MerleauPonty sobre Cézanne: "Por que tanta incerteza, tanto labor, tantos fracassos e, subitamente, o maior sucesso?"92 Para além da qualidade de sua obra, atualmente um consenso do circuito no arte, e em vez de encontrar uma resposta objetiva para esse disparate que a própria história acabou reavaliando, talvez seja interessante reparar na semelhança da dúvida desses dois artistas que possuem alguns trabalhos que poderiam ser aproximados, como de fato fez Alberto Tassinari ao analisar alguns desenhos bem posteriores, já do início dos anos de 1980.

\footnotetext{
90 Schendel, Mira. in: Salzstein, Sônia. "No vazio do mundo", op. cit., p. 83.

91 Salzstein, S. "Entrevista com Haroldo de Campos." No vazio do mundo, op. cit. p. 231.

92 Merleau-Ponty. "A dúvida de Cézanne". op. cit. p. 303.
} 
"A natureza-morta tem sido um dos principais gêneros da pintura moderna. Depois das maçãs de Cézanne, dos limões de Braque, ou das garrafas de Morandi, é difícil acreditar que um pintor ainda possa nos comover com essa mistura de sentimentos íntimos, quase secretos, mas por outro lado cósmicos, que desperta a natureza-morta. No entanto, é o que ocorre, creio, quando se observa a recente série de catorze desenhos de Mira Schendel intitulada Mais ou menos frutas. ${ }^{\prime \prime 3}$

O desenho de Mira Schendel surge da cor e os contornos de suas maçãs podem ser comparados aos do pintor francês. A linha movimenta o espaço, dá origem a toda espacialidade dos desenhos. É dela que surgem as maçãs e também o horizonte, ela está diante de nós, mas escapa para o fundo, para as bordas, para o interior das frutas, para seu exterior. Segundo Tassinari, a linha "vibra, instaura o espaço, faz surgi-lo pulsando como cheio ou vazio, mas não possui ela mesma um lugar fixo."

Sem jamais abandonar o pensamento, o desenho e a pintura de Schendel estão mergulhados na expressão, assumindo a história e a tradição para fundá-las novamente em seu trabalho, ou seja, sua obra é trabalho interminável:

\begin{abstract}
"Ao se traçar o contorno de uma maçã, faz-se dela uma coisa e, no entanto, não é senão o limite ideal em direção ao qual os lados da maçã correm em profundidade. Não marcar nenhum contorno seria tirar a identidade dos objetos. Marcar apenas um seria sacrificar a profundidade, isto é, a dimensão que nos dá a coisa, não estirada diante de nós, mas repleta de reservas, realidade inesgotável." ${ }^{\prime 5}$
\end{abstract}

Mira Schendel já havia se pronunciado sobre sua tentativa "frustrada" de "surpreender o discurso no momento de sua origem"

\footnotetext{
93 Tassinari, Alberto. "Mais ou menos frutas", Folhetim. Folha de São Paulo, São Paulo, 23 de Setembro, 1984.

${ }^{94}$ Idem, ibidem.

${ }^{95}$ Merleau-Ponty. "A dúvida de Cézanne". op. cit. p. 307.
} 
ou de sua busca pela "escrita pré-literal e pré-discursiva." ${ }^{196}$ Embora ela estivesse se referindo ao trabalho com letras, a expressividade de seus desenhos e pinturas é acompanhada de uma mudez anterior à reflexão, como se captassem a natureza em sua origem, anterior à distinção entre pensamento e mundo sensível. Como em alguns trabalhos de Cézanne, parece existir uma identidade entre a pintura e a consciência na obra de Schendel. Do mesmo modo, Cézanne "quer pintar a matéria ao tomar forma, a ordem nascendo por uma organização espontânea." 97 Ele irá se aproximar do mundo pré-reflexivo, buscando a todo custo evitar a alternativa entre sensação e pensamento ou entre caos e ordem: "É este mundo primordial que Cézanne quer pintar e eis porque seus quadros dão a impressão da natureza à sua origem." ${ }^{\prime 98}$

Mário Schenberg já havia observado a respeito das primeiras pinturas a óleo ou têmpera de Schendel um "forte sentido ontológico". Na exposição que a artista fez no Museu de Arte Moderna de São Paulo, em 1954, havia "algumas paisagens de tendência ontológica, admiráveis pela singeleza e melancolia." ${ }^{\prime 99}$ Certa melancolia e nostalgia do ser também existiam na pintura de Morandi, que se opôs à aceleração e ao movimento mecânico da era das máquinas, assim como ao elogio da velocidade da arte futurista.

Segundo Schenberg, em 1963, na mostra de Mira Schendel na Galeria São Luis, foi possível apreciar nos óleos e têmperas da artista o momento "em que o rigor da construção e a contenção do colorido e da textura nos faziam sentir o Ser parmegiano, imutável

\footnotetext{
${ }^{96}$ Schendel, Mira. in: Salzstein, Sônia. "No vazio do mundo", op. cit., p. 256.

97 Merleau-Ponty. "A dúvida de Cézanne". op. cit. p. 306.

${ }^{98}$ Idem, ibidem.

${ }^{99}$ Schenberg, Mário. "Mira Schendel". op. cit.
} 
e rígido em sua identidade."100 Aos poucos, esse "Ser rígido e maciço" foi sendo ameaçado pelo vazio e pelo nada, momento em que as pinturas se distanciaram dos desenhos cheios de coloridos e com aspectos mais sensoriais. Dez anos depois da mostra feita no MAM:

\footnotetext{
"Mira transubstanciaria a solidão e a melancolia individual no drama cósmico de suas paisagens ontologias. As casas deixaram de ser refúgios de criaturas sem horizonte. Abrem-se agora para o espaço insondável. Mira descobriu espaços horizontais e verticais magníficos. Espaços humanos novos que superam a transcendência gótica e barroca. Espaços de imanência. ${ }^{\prime 101}$
}

O que Schenberg chama de espaços de imanência é exatamente o que Merleau-Ponty chama de fissão no Ser de indivisão. Um modo do Ser dividir-se por dentro sem separar-se de si mesmo, dando a ver um mundo originário que ultrapassa o instituído sem sair da visibilidade. É o mesmo que se torna outro no interior de si mesmo.

O texto de Schenberg termina com a afirmação de que a obra de Mira Schendel nos leva para "novas possibilidades de apreensão da natureza". É provável que a natureza tal como vista pela artista não se oponha a arte. Cézanne também escreveu que queria unir "Natureza e arte". Para isso seria preciso por o mundo cultural em suspensão, como se o mundo exterior se pensasse no interior do artista. A arte compreendida desse modo, em vez de imitação é expressão. E a expressão, pela sua própria natureza, é tarefa infinita.

As circunstâncias em que foram realizados os trabalhos de Schendel e Cézanne são completamente diferentes e elas sozinhas jamais poderiam dar conta da intenção da obra. A vida do artista, o

\footnotetext{
${ }^{100}$ Idem, ibidem.

${ }^{101}$ Idem, ibidem.
} 
meio em que viveu, a admiração por artistas que conheceu, a sua carga genética ou cultural são antes acidentais do que essenciais na biografia de um artista. São condições, mas o modo como cada um dos artistas lida com elas, interpreta e dá sentido a elas jamais poderia ser determinado, por isso o trabalho do artista é livre de qualquer sentido histórico necessário.

Merleau-Ponty aborda o trabalho de arte como conversão da vida, ou melhor, como a transição da necessidade à liberdade e, portanto, expressão livre do que precisa necessariamente ser expresso. A vida não é causa de uma obra específica porque a arte é existência, é ela que dá um sentido à vida: "É certo que a vida não explica a obra, porém certo é também que se comunicam. A verdade é que esta obra a fazer exigia esta vida." ${ }^{102}$ Por isso podemos dizer que a obra de Schendel não é mero resultado das dificuldade de alguém que foi refugiada de guerra e imigrante, mas sua obra e sua vida compartilham esse mesmo drama. Seu trabalho de arte, para além de qualquer proximidade com a pintura metafísica, revela o sentido metafísico de sua vida.

102 Merleau-Ponty. "A dúvida de Cézanne". op. cit. p. 312. 
uma arte de vazios onde a extrema redundância começa a gerar informação original uma arte de palavras e quase palavras onde signo gráfico veste e desveste vela e desvela súbitos valores semânticos uma arte de alfabetos constelados de letras-abelhas enxameadas ou solitárias $a-b(l i)-a a$ Haroldo de Campos ${ }^{103}$

${ }^{103}$ Fragmento do texto escrito em abril de 1966 e publicado no mês seguinte no catálogo da exposição Mira Schendel, que aconteceu no mesmo ano no Museu de Arte Moderna do Rio de Janeiro. 


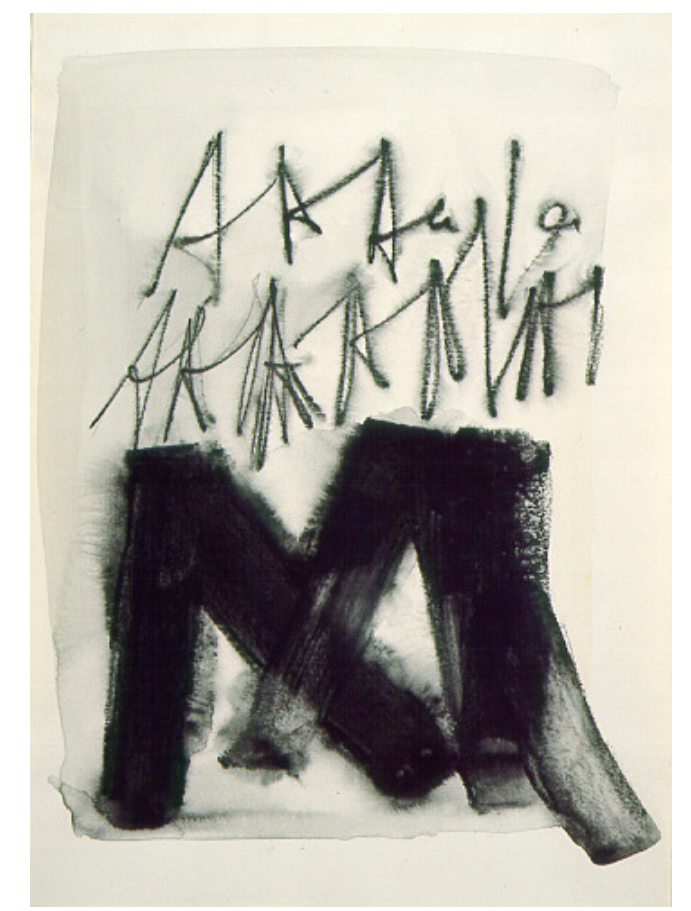

Sem título, (da série "Aaaa..."), c. 1960 pastel seco e aguada sobre papel, $34 \times 24 \mathrm{~cm}$ Coleção MAM-SP

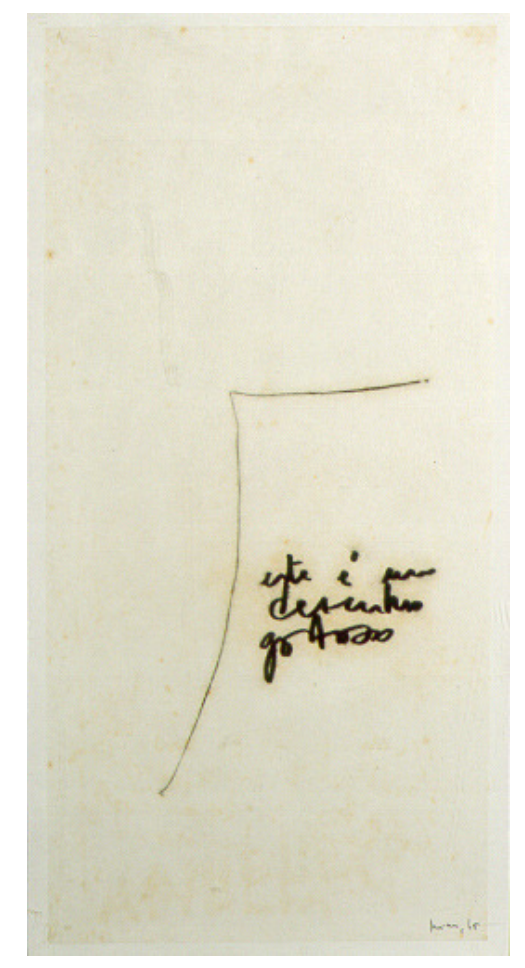

Este é um desenho gostoso, 1965,

monotipia (óleo sobre papel arroz), $47 \times 23 \mathrm{~cm}$ Coleção MAM-SP 


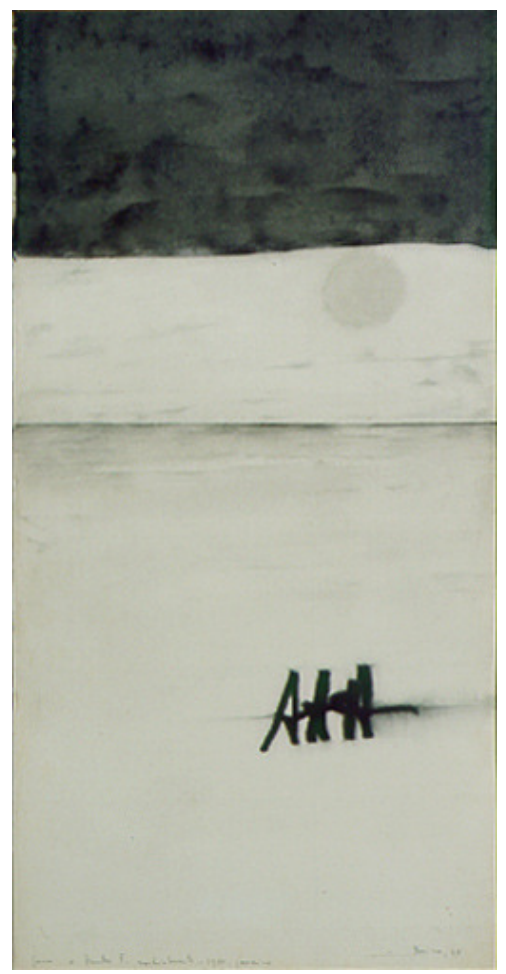

Sem título, 1978,

ecoline e pastel seco sobre papel, $47,1 \times 23,8 \mathrm{~cm}$ Coleção MAM-SP

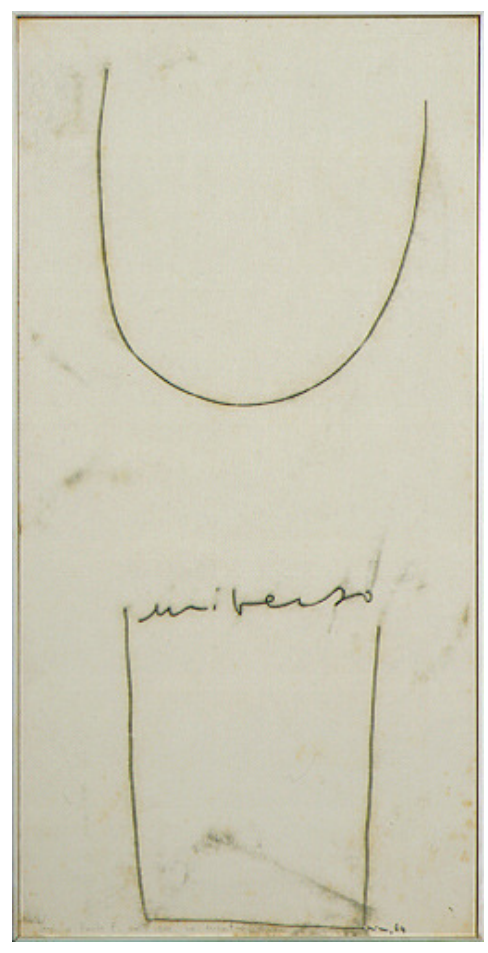

Universo, 1964, monotipia (óleo sobre papel arroz), $47 \times 23 \mathrm{~cm}$ Coleção MAM-SP 

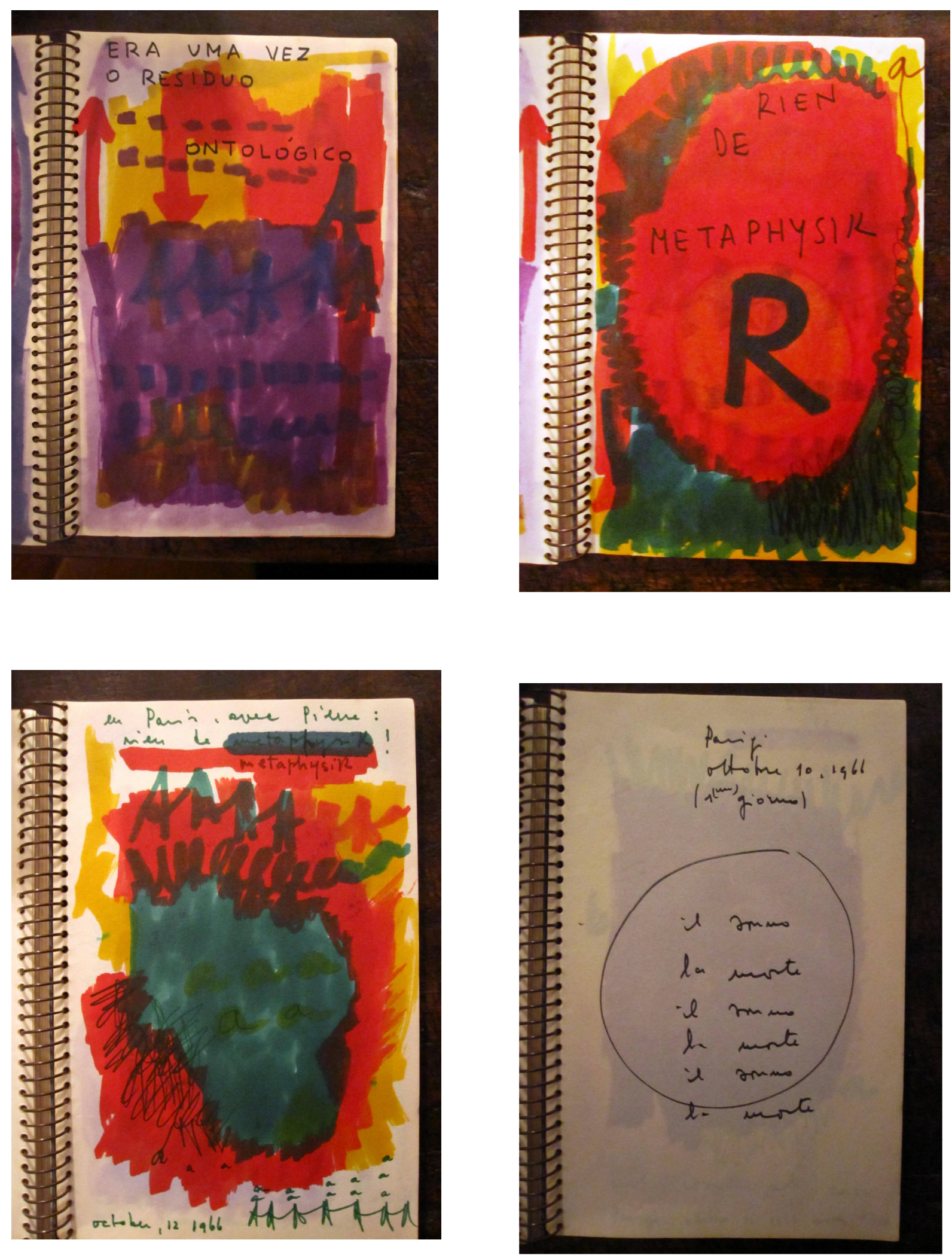

Páginas do diário de Mira Shcendel, 1966 
"A poesia força as palavras a dizerem o contrário do que elas pretendiam." O Avesso das Coisas, 1987 Carlos Drummond de Andrade

\section{Os limites da linguagem e o fim da metafísica}

A escritura que surge nos papéis de Mira Schendel, uma escrita pré-discursiva em que desenho e letra se integram, não poderia de modo algum ser apenas a tradução de sentidos anteriores a ela mesma. Essa escrita jamais poderia ser concebida como ideal e pura, como se pudesse traduzir sem equívocos pensamentos e sentimentos. Se assim fosse, a linguagem seria somente um instrumento, supostamente perfeita e transparente. Mas a linguagem, principalmente a do poeta ou artista, não traduz significações, é 
habitada por elas. O sentido não está fora do mundo, uma vez que ele não pode ser anterior nem exterior à palavra. Por isso, a linguagem presente em grande parte dos papeis de Mira Schendel é alusiva e indireta. A artista não copia nem traduz pensamentos, mas se deixa fazer e refazer por eles. É como se em seus desenhos houvesse a busca de uma escrita originária, anterior aos significados já estabelecidos, ao já dito, ao discurso já proferido. Em um de seus escritos, como já dissemos, Mira Schendel disse que buscava "surpreender o discurso no momento de sua origem"104. Sua pesquisa foi caracterizada, por ela mesma, como "a tentativa de imortalizar o fugaz, e de dar sentido ao efêmero"105.

Seus gestos fixados nos papéis, assim como suas letras e palavras manuscritas, são instituintes. Ao mesmo tempo em que instituem novos sentidos, recorrem à origem do próprio gesto, ao que ele possui de primordial e inaugural. Motivo pelo qual podemos dizer que o silêncio e o vazio em Mira Schendel são significantes, porque é como se eles reinventassem a caligrafia e a própria linguagem. Em sua escrita nem sempre há coerência dentro de um dado sistema semântico. Além disso, seus escritos não parecem surgir da unidade de regras gramaticais de uma língua, mas da mistura de diversos idiomas com que a artista tinha familiaridade, como o português, o alemão e o italiano. Vilém Flusser, em carta para artista, descreveu seu próprio processo de escrita e o comparou com o modo como Mira Schendel trabalhava. Primeiro ele escrevia em alemão, sua língua materna, em seguida traduzia para o português, depois para o inglês e, finalmente, para língua em que o texto seria publicado:

\footnotetext{
"O que procuro é isto: penetrar as estruturas das várias línguas até um núcleo muito geral e despersonalizado, para poder, com tal núcleo pobre, articular a minha liberdade. [...] Creio que em certo momento você [Mira Schendel] trabalha de maneira semelhante. ${ }^{\prime 106}$
}

\footnotetext{
${ }^{104}$ Folha datilografada, sem título e sem data encontrada em seu arquivo pessoal.

${ }^{105}$ Idem, ibidem.

${ }^{106}$ Flusser, Vilém. Carta a Mira Schendel de 27 set. 1974.
} 
O que esse procedimento de Flusser e o de Mira Schendel demonstra talvez seja a busca de algo que pertença a todas as línguas, como se o método liberasse algo que sobra da língua na tradução. Isso permite maior aproximação ao estado nascente do pensamento. Esse excesso de sentido, essa sobra da língua é a matéria prima do trabalho gráfico de Schendel e ao mesmo tempo é o impensado de cada idioma. É como se um núcleo independente e originário das línguas, o que há em comum entre elas e que possibilita a tradução, atuasse na passagem de uma língua para outra. Esse é um campo fértil para compreender as monotipias, especialmente quando Schendel funde diferentes idiomas. Esse campo originário de liberdade permite perceber o movimento da língua como signo para o seu aspecto gráfico, como em alguns dos Toquinhos feitos em papel e também nos Datiloscrítos. Neles se revela algo que não pertence a nenhuma língua ou que talvez pertença a todas as línguas. É desse núcleo nascente da língua que brota a complexa relação entre o desenho e a palavra, o gestual e o não gestual em seu trabalho.

Segundo o filósofo e ensaísta alemão Max Bense, com quem a artista estabeleceu diálogo principalmente nos anos de 1960, os traços de Schendel são "elaborados por mãos que refletem". Além disso, as letras são como pontos, elas formam linhas e abrem espaços. Em um curto texto sobre o trabalho de Schendel Bense abordou de passagem certa dimensão filosófica de seu trabalho:

"aquilo que se passa, passa-se sobre a mais extrema pele da substância do mundo, ali onde o mundo poderia começar a infiltrar-se na consciência, na linguagem."107

107 Bense, Max, "Mira Schendel: reduções gráficas". Pequena Estética. São Paulo: Editora Perspectiva, 1971. A totalidade do texto de Max Bense foi impressa originalmente no catálogo da exposição de desenhos de Mira Schendel no Studium generale/ technische hochschule, Stuttgart, em 1967. 
O que Bense chama de "pele da substância do mundo" é esse campo ambíguo onde mundo e consciência não se opõem. No campo da linguagem uma analogia poderia ser a complementaridade do significante e do significado.

Mas a linguagem em Schendel, antes de ser objeto de estudo é experiência, ela é vivida por dento como língua e se desdobra em signos. Há nela a vontade de se desfazer da sensação ingênua que geralmente temos de que a nossa língua materna pode captar completamente, expressar sem qualquer dúvida ou lacuna o nosso pensamento. O que aparece em seu trabalho são justamente as lacunas, os intervalos, a falta e o excesso de sentido presentes nos signos e na língua.

Segundo Merleau-Ponty, é necessário nos desfazermos da "ideia de um texto original de que a língua seria a tradução ou a versão cifrada, $[. .$.$] a ideia de uma expressão completa é destituída$ de sentido."108 É de um fundo silencioso, ou do vazio, que a linguagem surge. E se ela chega a atingir as próprias coisas, se parece às vezes que até pode as substituir, de fato ela não o faz, porque funciona sempre como alusão, como abertura, pois ela exprime tanto pelo que diz como pelo que fica entre as palavras, oculta silenciosamente nelas.

Cada elemento da linguagem é compreendido em relação aos outros e não como parte atomizada, por isso, como sublinha MerleauPonty, no ato sincrônico da fala ou da escrita está contida a totalidade da língua e também todas as diferenças que a constituem ${ }^{109}$. Só é possível compreender uma língua quando minimamente se faz parte da instituição cultural que a estrutura. Se em cada expressão a língua inteira está presente é porque em cada uma delas a totalidade da língua é mobilizada. Mas também a diacronia (as transformações de uma língua no tempo) pressupõe a

\footnotetext{
108 Merleau-Ponty, "A linguagem indireta e as vozes do silêncio". op. cit. p. 72.

109 Merleau-Ponty discute a relação entre diacronia e sincronia no texto "Sobre a fenomenologia da linguagem", onde recorre à linguística de Saussure.
} 
língua inteira. A sincronia (a totalidade da língua) contém todos os princípios da autotransformação da língua, nela está presente tudo aquilo que ela poderá se tornar, por isso a diacronia é imanente a ela. Ou seja, tudo o que a língua pode ser encontra-se nela mesma como possibilidade interna e não apenas em acontecimentos externos, em condições históricas ou sociais. Se alguns acontecimentos externos à língua são incorporados por ela é porque ela tem a capacidade de captá-los e, portanto, de se transformar. Segundo Merleau-Ponty, "a história [da linguagem] é história de sincronias sucessivas, e a contingência do passado invade o sistema sincrônico". ${ }^{110}$ Por isso a linguagem não pode ser um fato acabado, algo do passado, e também por isso que alguns acasos ou acontecimentos fortuitos da história da língua podem ser integrados a ela.

A língua contém os princípios de transformação de sua estrutura e é isso o que Schendel não cessa de explorar. A língua para ela, em especial nas inscrições que faz nas monotipias, é compreendida em seu devir, como movimento e fecundidade. A língua está longe de ser um mero invólucro do pensamento, um assessório do pensamento. Não se trata de conceber a língua como capaz de meramente traduzir ideias, mas sim de um sistema, de uma totalidade viva. É como se os trabalhos de Mira Schendel se valessem das fendas da língua para surgirem e se inserirem no mundo. São seus gestos que tornam as palavras pregnantes. É o gesto, assim como a entonação ou alteração da voz na linguagem oral, que dá textura à palavra. É dele que surge a expressividade. E segundo Merleau-Ponty:

\footnotetext{
"Toda expressão sempre me aparece como um vestígio, nenhuma ideia me é dada na transparência e todo esforço para fechar nossa mão sobre o pensamento que habita a palavra deixa apenas um pouco de material verbal entre nossos dedos." ${ }^{111}$
}

${ }^{110}$ Merleau-Ponty, "Sobre a fenomenologia da linguagem" in: Textos Escolhidos. op. cit. p. 322.

${ }^{111}$ Idem, ibidem. p. 323. 
A expressão é possível porque um significante abriga vários significados. Mas ao mesmo tempo em que o significado pode ir muito além do significante, ele não pré-existe ao significante. Mas é graças a ele que os sentidos surgem, graças à potência significante da palavra.

Haroldo de Campos chamou atenção para o fato de que no trabalho de Schendel "entre significante e significado" a surpresa sempre volta a circular ${ }^{112}$. Por isso, na investigação da artista, a escrita e a caligrafia não se esgota no gesto expressivo. Trabalhos como os Datiloscritos, mas também alguns dos Toquinhos, ambos dos anos de 1970, trazem coladas sobre o papel ou o acrílico letras adesivas e pré-fabricadas que se desenvolvem em distintas estruturas compostas por elementos gráficos. Apesar do "espaço gráfico como agente estrutural"113 e do aspecto serial das letras, não há proximidade entre estes trabalhos e os poemas concretistas.

Tanto a poesia concreta como os trabalhos de Mira Schendel são altamente experimentais, entretanto, há diferenças consistentes entre os concretistas e Schendel. Há por parte dela uma recusa da ênfase que os poetas concretistas deram a uma "poesia de criação objetiva, concreta, substantiva", "contra a poesia de expressão subjetiva". ${ }^{114}$

O que os separa, e que está pressuposto no trabalho de Mira Schendel, é não apenas uma recusa de certo objetivismo concretista, mas uma dissolução das próprias categorias disjuntivas de "coisa" ou "consciência", coisa como objeto ou exterioridade oposta à interioridade subjetiva ou à consciência, o que implica numa

112 Campos, Haroldo. "Mira Schendel", Museu de Arte Moderna do Rio de Janeiro, maio de 1966. in: Salzstein, No vazio do Mundo, op. cit. p. 260.

113 Augusto de Campos, Décio Pignatari, Haroldo de Campos. "plano-piloto para a poesia concreta", em Teoria da poesia concreta. Cotia, SP: Ateliê Editorial, 2006. p. 215.

${ }^{114}$ Pignatari, D. "nova poesia: concreta (manifesto)", em Teoria da poesia concreta. op. cit. p. 68. 
reviravolta metafísica. Inicialmente os artistas concretistas estavam numa busca por formas universais objetivas para que pudessem fugir do subjetivismo das opiniões, enquanto as pesquisas de Mira Schendel, mesmo que não se trate de um projeto deliberado, se encaminhou para a superação da antinomia clássica do subjetivo e do objetivo.

Haroldo de Campos, ao chamá-la de "calígrafa metafísica", marca uma distância entre Schendel e os concretistas, que de fato não tinham as mesmas questões filosóficas em seu horizonte, mas revela bastante intimidade com seu trabalho. Certamente há interesses comuns em relação à tipografia e a elaboração de poemas visuais. Segundo Haroldo de Campos, sua escritura:

\footnotetext{
"nem sempre é létrica, às vezes não são letras nem palavras, e o quadro já é um poema, um poema-quadro, um quadro-poema. Certas escrituras são traços, são resíduos, são resquícios, são restos que ela deixa no papel, deixa aflorar no papel, deixa percorrer o papel, como se fossem rastros existenciais, ontológicos". ${ }^{115}$
}

Ao mesmo tempo em que o trabalho de Schendel é impregnado pela ontologia, ele está imerso numa série de indagações sobre a pertinência e sobre o fim da metafísica. ${ }^{116} \mathrm{Em}$ um de seus cadernos, ela chegou a anotar a última proposição do Tractatus LogicoPhilosophicus, de Wittgenstein: "Sobre aquilo de que não se pode falar, deve-se calar"117, que marca impossibilidade de a linguagem dar conta da metafísica.

Vilém Flusser também escreveu a respeito do trabalho de Schendel sobre o sentimento de insuficiência da língua e da aporia que o silêncio a que se refere Wittgenstein colocaria a filosofia:

115 Campos, Haroldo de. "Entrevista com Haroldo de Campos". in Salzstein, No vazio do Mundo. op. cit. p. 234.

${ }^{116}$ Conferir imagens de seu caderno no início do capítulo.

117 Wittgenstein, Ludwig. Tractatus Logico-Philosophicus (trad. Luiz Henrique Lopes dos Santos). São Paulo: Edusp, 2008. p. 281. 


\begin{abstract}
"Parece que não é apenas este ou aquele filósofo que chegou aos limites da linguagem, mas a filosofia em sua totalidade. Estamos avistando o fim da filosofia - a não ser que já o tenhamos alcançado. Parece que o que quer que a filosofia tenha a dizer, não poderá ser dito, e assim a própria filosofia reduz-se ao silêncio. Naturalmente, isto não pode ser aceito sem que se procure uma saída do dilema. ${ }^{118}$
\end{abstract}

Como a história não terminou, a resposta sairá da própria arte. Mira Schendel jamais se limita ao pseudo-limite da linguagem, uma vez que o uso que faz dela é originário e cada gesto seu será como o primeiro, fundando o seu próprio campo. Apesar do voto de silêncio da filosofia analítica, a arte irá encontrar um novo modo de articulação e expressão do pensamento filosófico, que indiretamente estará presente na arte.

Para Flusser, os cadernos de Mira Schendel são "desafio aos cadernos de Wittgenstein"119, ou seja, eles conseguem, fora do campo da língua, dizer aquilo que a língua talvez não poderia, ou melhor, não seria capaz porque justamente não é o modo como a artista se expressa primordialmente. Segundo Mira Schendel, "para mim é muito difícil falar do meu trabalho, porque realmente, se eu pudesse falar ou escrever eu acho que eu não pintaria ou desenharia." ${ }^{120}$ Por isso, para Flusser, os cadernos de Mira Schendel "devem ser lidos fora da linguagem, mas dentro da nossa tradição filosófica". ${ }^{121}$

O contra-senso é que o Tractatus Logico-Philosophicus de Wittgenstein, embora decrete a insuficiência da linguagem para dizer algo sobre a metafísica também é um livro de filosofia e pressupõe uma metafísica ou ao menos o inefável: "Há por certo o inefável. Isso se mostra, é o Místico"122. Wittgenstein reconhece que qualquer coisa

\footnotetext{
${ }^{118}$ Flusser, Vilém. "Fora do alcance da língua" Arte em São Paulo. São Paulo, n. 36, 1987, p 44.

${ }^{119}$ Idem, ibidem.

120 Entrevista dada a Jorge Guinle Filho, "Mira Schendel, pintora", Interview, São Paulo, jul. 1981, p. 54.

${ }^{121}$ Flusser. "Fora do alcance da língua" op cit.

122 Wittgenstein, Ludwig. op. cit. (6.522). p. 281.
} 
que se pretenda dizer sobre o místico e sobre o metafísico será um contra-senso e o seu livro também é um contra-senso. A saída para tal aporia será justamente a analogia entre a filosofia e a escada. Segundo Wittgenstein, na penúltima proposição do Tractatus, a escada deve ser descartada depois de seu uso:

\begin{abstract}
"Minhas proposições elucidam dessa maneira: quem me entende acaba por reconhecê-las como contra-sensos, após ter escalado através delas - por elas - para além delas. (Deve, por assim dizer, jogar fora a escada após ter subido por ela.) Deve sobrepujar essas proposições, e então verá o mundo corretamente". ${ }^{123}$
\end{abstract}

Não se trata de afirmar que não existe mais filosofia, a filosofia é uma atividade e não um conjunto de proposições, o problema estaria na ilusão metafísica, na filosofia querer dizer o que não pode ser dito, mas deve ser conhecido. De acordo com a concepção de linguagem de Wittgenstein, seria preciso nos contentar com os limites da linguagem, ou seja, os limites do pensamento. Como o limite do mundo é o da linguagem, para que não se elaborem mais contrasensos restaria o silêncio.

Mira Schendel de modo algum irá se dar por satisfeita com o silêncio e seu trabalho diz algo que de fato não possui equivalente no campo da lógica e da linguagem tal como concebe a filosofia analítica. Além disso, ela irá reconhecer os limites do Tractatus e a leitura positivista dele. Num caderno sem data, mas certamente do final dos anos de 1980, Mira Shendell escreveu:

"O neo-positivismo - filosoficamente - pifa. E com ele boa
parte Wittgenstein. Mas concordo com ele plenamente aqui:
'se deve, por assim dizer, tirar a escada depois de ter
subido'."124

Tirar a escada, para Mira Schendel, é não mais ter uma filosofia como reposta definitiva ou apoio seguro às suas indagações, como um campo superior que levaria ao místico e ao metafísico. Mesmo

\footnotetext{
${ }^{123}$ Idem, ibidem. (6.54). p. 281.

${ }^{124}$ Anotação em diário sem título de seu arquivo pessoal, c.1987.
} 
assim, a artista não irá abrir mão de dizer o que a linguagem não seria capaz para Wittgenstein. Se a linguagem escrita tem seus limites, a arte pode expressar aquilo que ela não consegue, uma vez que ela recusa a transparência da linguagem da filosofia analítica e recorre a outra transparência, a da matéria, tanto no papel como no acrílico.

Diferentemente de Wittgenstein do Tractatus, a linguagem para Merleau-Ponty não pode ser apenas representação plena de algo, ao contrário, ela é opaca, é misteriosa, marcada por ambiguidades e não aquilo que simplesmente traduz ideias, senão estaríamos presos nela como numa camisa-de-força. A concepção de linguagem de MerleauPonty se distancia de Wittgenstein na medida em que ele não a toma como proposição, nem como denotação, nem como determinação completa. $\mathrm{Na}$ verdade, ele recusa a ideia de que possa haver expressão completa, uma vez que em cada expressão há uma falta e um excesso de sentido e é isso que irá permitir outras expressões. "A linguagem diz, e as vozes da pintura são as vozes do silêncio"125, portanto, o silêncio não se opõe à fala e sim é o que a permite. Segundo Merleau-Ponty, "nenhuma linguagem se separa totalmente da precariedade das formas de expressão mudas". ${ }^{126}$

A linguagem é viva e não tem nada da fixidez com que aparece para o filósofo analítico. Para Wittgenstein, a linguagem conduziria à supressão do sujeito, uma vez que ele não pode se representar por meio da linguagem, cuja tarefa principal é afirmar ou negar situações objetivas e que correspondam plenamente a fatos simples. Desse modo, é como se Wittgenstein retirasse o sujeito de seu próprio corpo e como se só fosse possível pensar como um mero objeto entre outros objetos exteriores do mundo.

Para Mira Schendel, a noção de corporeidade é fundamental e seus cadernos, ao recusarem o uso da linguagem como proposição,

125 Merleau-Ponty. "A linguagem indireta e as vozes do silêncio". O olho e o espírito. São Paulo: Cosac \& Naify, 2004, p.115.

${ }^{126}$ Idem, ibidem, p. 113. 
ao torcerem a linguagem a ponto de ela não mais ter um significado objetivo, passando a ser antes um elemento gráfico do que sintático e, em muitos cadernos, abandonar a própria escrita, explorando a visualidade e temporalidade das letras, de fato eles estão mais ligados à concepção de linguagem de Merleau-Ponty do que de Wittgestein.

Segundo Aracy Amaral em textos sobre os cadernos de Mira Schendel, "sua forma atual de expressão é tão ampla, que ela poderia se situar entre 0 conceitual e o objeto artístico convencional."127 Mais adiante no texto, depois de afirmar que "o metafísico paira sobre todo o conjunto se sua obra", a crítica e historiadora desenvolve seu raciocínio:

\begin{abstract}
"Uma arte de aspecto conceitual e não-conceitual (partindo da especulação e nela se desenvolvendo), pois com uma referência física que pode ser arte ou não ser, segundo o determine a artista, para quem o signo nunca chega a referência figurativa, mas permanece sempre como tal, mental, embora visível. ${ }^{\prime 128}$
\end{abstract}

Os cadernos de Mira Schendel, mesmo que se aproximem da arte conceitual ou cheguem ao limite da não-arte, ou até mesmo próximo do que depois foi chamado de fim da arte, jamais abandonam o campo da visibilidade. Em seu caso, o conceito nunca poderia substituir o contato direto com a materialidade dos cadernos, que exigem manipulação e contato direto, mesmo porque em alguns deles sequer há palavras, mas sinais gráficos que vão se relacionando, se movimentando e se sobrepondo a partir da transparência das páginas. Mesmo quando há letras em seus cadernos, elas são antes sinais gráficos que vão se desdobrando e se transformando conforme as páginas são viradas. $\mathrm{O}$ " $\mathrm{q}$ " se transforma em " $\mathrm{p}$ ", que se torna " $\mathrm{d}$ " e em seguida "b". É como se o tempo se infiltrasse nos cadernos e provocasse uma rotação completa das letras, fazendo com que elas

127 Amaral, Aracy. "Mira Schendel: os cadernos". Arte e meio artístico: entre a feijoada e o x-burguer. São Paulo: Nobel, 1983. p. 183.

${ }^{128}$ Idem, Ibidem, p. 185. 
aludissem a sons distintos de acordo com as coordenadas espaciais pelas quais elas se situam.

Em 1973, o então estudante da Escola de Superior de Belas Artes de Hamburgo, Robert Darral, fez um filme em dezesseis milímetros com dois cadernos de Mira Schendel. Nele, conforme as páginas são viradas, as letras e formas aparecem dançando no espaço em branco da página, em constante movimento.

A noção de estrutura de Merleau-Ponty poderá contribuir na compreensão desses trabalhos e é justamente ela que irá nos levar para além da objetividade pura e da subjetividade pura e, portanto, permitirá o abandono da ideia de constituição transcendental, de um sujeito que põe a realidade como significação. A estrutura é um princípio de distribuição e não uma essência, uma coisa, tampouco uma ideia, ela é significação encarnada. Ela é um sistema de relações e diferenças internas. Assim como um Caderno de Mira Schendel, a estrutura não é um arranjo de partes que podem ser isoladas, é uma totalidade. $\mathrm{E}$ o todo tem um sentido que as partes independentes não têm. Ela é um princípio interno de organização em que cada mudança parcial provoca uma mudança no todo. Segundo Merleau-Ponty, a estrutura é um modo novo de ver o Ser, que está agora fora da metafísica dualista e da oposição entre consciência e corpo ou do para-si e do em-si. A estrutura pertence ao mundo pré-reflexivo e, segundo Merleau-Ponty, nos leva ao Ser de indivisão, uma vez que cada uma das estruturas são dimensões de um mesmo Ser em que ideia e existência são inseparáveis. A gênese da estrutura não está em outro lugar senão nela mesma, por isso um trabalho de arte não surge de uma estrutura, se assim fosse restaria à artista apenas derivá-lo logicamente, mas ele é uma estrutura, uma vez que a estrutura é a sua própria significação. Como a estrutura, o trabalho é uma unidade global avessa à determinação completa que jamais poderia ser apreendido de uma só vez. Ele é grávido, tem poder de eclosão, possui nele mesmo um princípio interno de transformação, é 
um acontecimento que tem em seu interior o princípio de seu devir. Como a estrutura, o trabalho é um arranjo contingente que nos possibilita fazer com que apenas a materialidade de um trabalho de arte faça sentido para quem o contemple.

Como a estrutura é fecundidade, a sincronia e a diacronia na língua poderão estar entrelaçadas. A sincronia contém os acontecimentos passados da língua e a possibilidade de seus desdobramentos no futuro. Assim, a língua é uma estrutura aberta ao possível e ao ausente, uma matriz simbólica, que permite com que se interrogue o mundo e a história de um modo sempre diferente e novo.

A nossa percepção não é apenas um mosaico, ou seja, uma troca entre estímulos externos fragmentados e respostas internas, num modelo de causa e efeito, tal como era para as ciências mecanicistas. Se assim o fosse, cada momento das letras dos cadernos de Mira Schendel, filmados por Robert Darral, seria percebido completamente como um momento isolado um do outro, como átomo. Não veríamos o movimento de um mesmo sinal gráfico girando e se tornando outro, mas vários sinais diferentes afetando a nossa percepção, como se o caderno fosse meramente uma soma de elementos separados um dos outros, um mosaico de estímulos. É a própria transparência das folhas que já proporciona o deslocamento das letras. Por isso, cada caderno de Schendel é uma totalidade, ou seja, é mais do que a soma de cada uma de suas páginas, uma vez que ele tem um sentido que nenhuma parte tem separadamente ou apenas somadas. Assim, cada caderno é também uma estrutura e as letras, sinais e palavras dele possuem pregnância. Além de serem completas em si mesmas elas engendram outra. $O$ " $q$ " engendra 0 " $p$ " e dele surge o " $d$ " e depois o " $b$ ". O que vemos é a continuidade, uma mesma letra se movendo e tornando-se outra como um único acontecimento, uma totalidade, uma estrutura. 


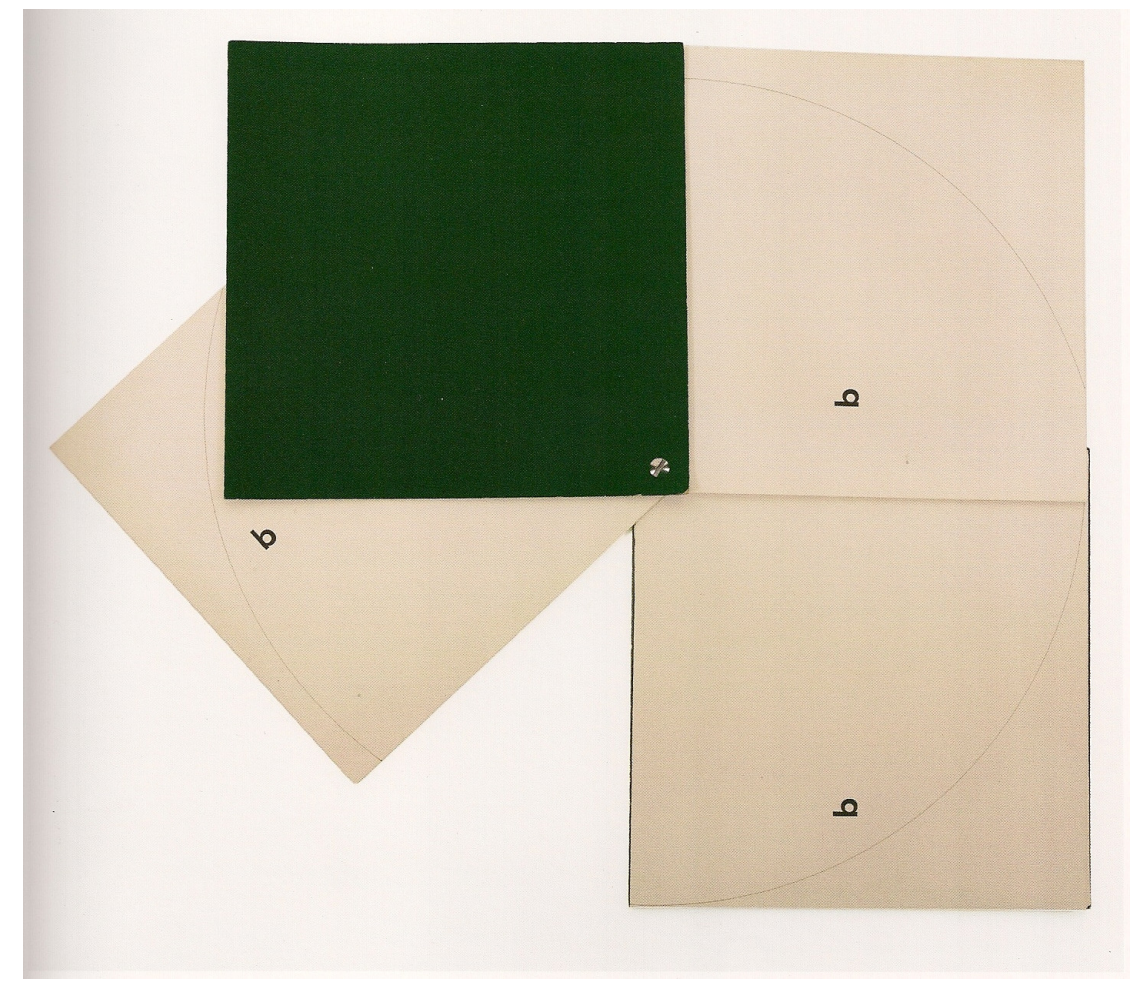

sem título [caderno], 1971

letraset sobre papéis encadernados, $20 \mathrm{~cm} \times 20 \mathrm{~cm}$ [fechado] 


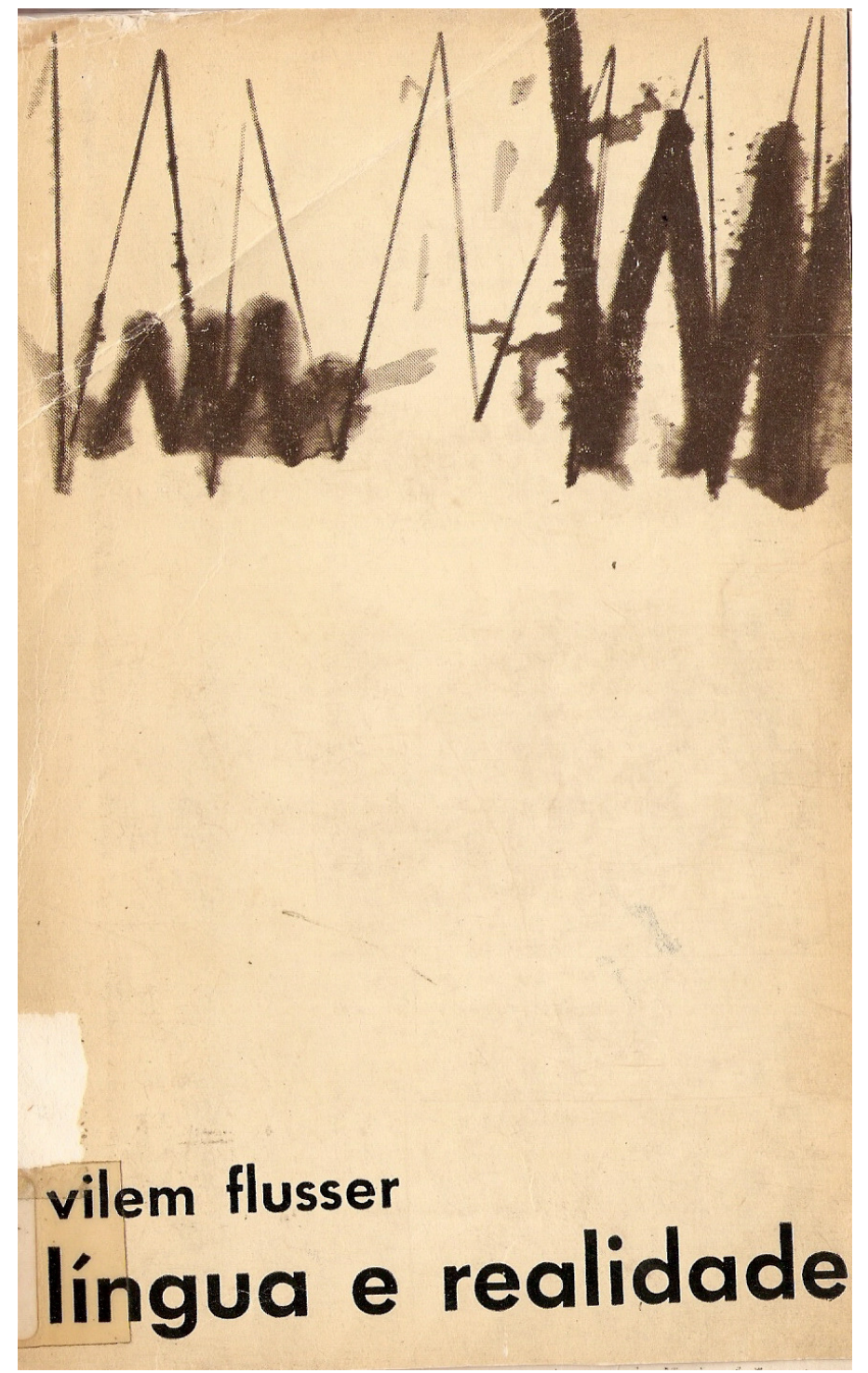

Capa do livro Língua e realidade, de Vilem Flusser, desenhada por Mira Schendel Editora Herder, São Paulo, 1963 


\section{Diálogos com Vilém Flusser: Língua e realidade}

O desenho da capa do livro Língua e Realidade ${ }^{129}$, de Vilém Flusser (1920-1991), intelectual tcheco filho de judeus que fugindo do nazismo chegou ao Brasil em 1940, foi elaborado por Mira Schendel. Mais do que simplesmente ilustrar o pensamento do autor ou executar mais um serviço de design gráfico, de fato ela desenhou uma série de outras capas para a editora Helder, Schendel parece em alguns momentos de sua obra se aproximar verdadeiramente das teses defendidas por Flusser nesse trabalho. A artista foi sua amiga, interlocutora, e frequentava assiduamente as reuniões de discussão filosófica ${ }^{130}$ que Flusser organizava em sua residência aos finais de semana.

Em sua "autobiografia filosófica"131, publicada postumamente, em 1992, Flusser aborda os diversos diálogos que manteve com escritores, como João Guimarães Rosa, artistas como Samson Flexor e intelectuais que vão de Haroldo de Campos a Miguel Reale. Há reservado no livro um capítulo especial para Schendel, onde ele aborda seu trabalho, sua personalidade e a influência mútua que exerceram um sobre o outro: "Nossos diálogos influenciavam o trabalho de Mira. E os trabalhos eram eles próprios dialogados. Tal feed-back fertilizava a nossa relação: eu sou autêntico crítico de Mira, e Mira é autêntico tema para meus pensamentos e minhas pesquisas." 132

Referindo-se a ela apenas pelo primeiro nome, o modo como ela assinava suas obras, a amizade entre eles é comparada por Flusser a uma montanha russa, ou a uma curva febril, tamanha a

\footnotetext{
${ }^{129}$ Flusser, V. Língua e Realidade. São Paulo: Editora Herder, 1963.

130 Nesse período, Schendel também se interessou pelo pensamento de Jean Gebser, com quem travaria contato direto anos depois. A artista chegou a conversar com Flusser sobre a obra do pensador. Conferir: Dias, G. S. Mira Schendel: do espiritual à corporeidade. op. cit. p. 141-144.

131 Flusser, V. Bodenlos - Uma autobiografia filosófica. São Paulo: Annablume, 2007

${ }^{132}$ Idem, ibidem, p. 186.
} 
oscilação. A despeito das divergências de posições, das faíscas que o contato entre duas personalidades fortes inevitavelmente provocou, e do afastamento que tiveram depois do retorno de Flusser para a Europa, época em que escreveu o capítulo sobre a artista, por volta de 1974, o diálogo que estabeleceram em torno das noções de "transparência" e "significado" no início dos anos de 1960, pode colaborar para a compreensão da dimensão filosófica do trabalho de Schendel.

A noção de transparência está ligada à capacidade do olhar em penetrar as superfícies e assim de abrir abismos para além da aparência externa dos objetos. Esse rasgo do olhar sobre o mundo pode revelar seus fundamentos assim como pode trazer à tona o vazio por trás das coisas. Para Flusser, "o nosso mundo vital ameaça se desfazer em nada. Está se tornando transparente, não no sentido de que não podemos mais ver nada, mas no sentido de que vemos apenas estruturas transparentes que deixam entrever outras estruturas transparentes. ${ }^{\prime 133}$ Assim, na medida que há para 0 pensador a percepção de que o mundo está cada vez mais transparente, aos poucos é como se o mundo perdesse a sua concretude. Se o significado é aquilo que os símbolos indicam, e uma vez que os símbolos representariam significados que em última instância remetem ao mundo das coisas concretas, com a dissolução do mundo tudo se transforma apenas em símbolos. Cada novo símbolo acrescentaria mais um significado ao mundo. E então, dirá Flusser: "Tudo pode significar doravante tudo, e isso é uma maneira de dizer que não há significados últimos no mundo. 'Transparência', em última análise, é possibilidade de ver significado por trás de tudo. E 'significado', em última análise, é possibilidade de transformar tudo em coisa transparente. ${ }^{134}$ Essa tautologia é também uma provocação a Schendel porque isso faria com que todo o seu trabalho, ou melhor,

\footnotetext{
${ }^{133}$ Idem, ibidem, p. 186.

${ }^{134}$ Idem, ibidem, p. 187.
} 
toda a arte que lida com o simbólico, perderia seu sentido em nome de um vale tudo. Os trabalhos de Schendel em papel arroz entre duas chapas de acrílico transparente, em que há inscrições de formas, palavras e letras soltas, como os Objetos Gráficos, em que não há um significado preciso para as inscrições, estão no horizonte de Flusser, uma vez que na sequência do texto ele irá citá-los, ressaltando a "força estética" deles. De fato, ele sempre teve franca admiração pelos trabalhos de Schendel, como os textos publicados sobre sua obra revelam, e inclusive foi presenteado pela artista com alguns deles. Esse vale tudo pode ser visto também como uma abertura do trabalho, uma vez que o público, o observador, poderá atribuir e inventar os sentidos, ou seja, elaborar as frases ou conexões entre as letras a partir do contato direto com a obra. É claro que daí surge uma inversão surpreendente, uma vez que a transparência se torna frequentemente opaca, uma interrogação frente à própria dificuldade de nosso olhar atravessar a espessura teórica do trabalho.

Ao lado dos objetos cotidianos e utilitários que manipulamos e que satisfazem as nossas necessidades imediatas, as obras de Schendel são enigmáticas, nelas residem alguns dos mistérios do mundo.

\footnotetext{
"Mas é enquanto experiência que as obras de Mira me preocupam a muito. São ensaios de tornar imagináveis conceitos. Mira procura traduzir o conceito de transparência e o conceito de significado em imagem da transparência e imagem do significado. Procura inverter a relação tradicional entre imaginação e razão discursiva. Tal relação tradicional é esta: (a) encontro algo concreto no curso da minha vida, e procura imaginá-lo para poder ultrapassá-lo; (b) procuro conceber a imagem que tenho, para poder compreender $\mathrm{e}$ manipular o concreto. Historicamente a fase (a) corresponde ao estágio mítico-mágico da cultura, e a fase (b) ao estágio epistemológico-técnico da cultura. As obras de Mira pertencem a um estágio posterior a ambos. Mira procede da seguinte maneira: (a) encontra um conceito no curso de sua vida, e procura imaginá-lo para poder compreendê-lo; (b) procura transformar a imagem em coisa concreta. Dessa forma tem a obra de Mira função violentamente desalienadora. Um dos aspectos da nossa alienação é a inimaginabilidade dos nossos conceitos. Tal alienação é
} 
superável por nova força imaginativa, a qual Mira nos oferece." ${ }^{135}$

Segunda a concepção de Flusser, antes de se defrontar com algo concreto Mira Schendel, talvez como um filósofo, está lidando prioritariamente com conceitos. A diferença é que ela como artista transforma esses conceitos em imagens, por isso ela estaria num estágio posterior aos que ele chamou de mítico-mágico e epistemológico-técnico da cultura. E ao transformar a imagem que constrói dos conceitos em coisa concreta, estaria ela nos desalienando.

Claramente há uma aposta incontida na força imaginativa como processo emancipador, como modo de nos recolocar no mundo, um novo "estar-no-mundo", diria Flusser. A mediação das imagens poderia, segundo o pensador de origem tcheca, nos ajudar a compreender a complexa estrutura do mundo, ou melhor, a tratar objetivamente os conceitos. Isso nas palavras de Flusser faz com que a gente se transforme em "sujeitos dos nossos conceitos", o que abriria caminho para a "reformulação da condição humana"136. Apesar de Schendel já na época em que o texto foi redigido ter abandonado um repertório da pintura moderna, ou pelo menos a ideia de planaridade e frontalidade, e se dirigido para a noção de corporeidade, a abordagem de Flusser contém explicitamente princípios românticos e iluministas presentes em boa parte da produção artística moderna. A artista, segundo o pensador, surge quase como uma heroína utópica e vanguardista e seu trabalho como uma promessa libertadora, como se a experiência estética pudesse não apenas alterar um sujeito singular, mas a própria condição humana. Flusser se vê como aquele que tem a função de divulgá-la e abri-la ao mundo, uma vez que ela viveu sua maturidade artística

\footnotetext{
${ }^{135}$ Idem, ibidem, p. 190.

${ }^{136}$ Idem, ibidem.
} 
num país periférico. Como se o trabalho de Schendel fosse sucumbir a um isolamento ou a incompreensão, ficando assim refém de um meio disperso, pouco profissional e da solidão da artista, o que de fato não ocorreu. Seus trabalhos tridimensionais como as Droguinhas de modo algum aspirava a uma transformação genérica da condição humana, mas antes parecem nos revelar, dada a sua fragilidade, a própria impossibilidade de sua generalização a ampliação. Eles dependiam mais de um gesto simples, inacabado, contingente, e de uma predisposição corporal que se aproxima de uma indeterminação do que do sentido unívoco e utópico que Flusser parece ter atribuído indiretamente à artista. Na verdade a força deles está menos nas imagens do que na esfera da ação e do processual. E ainda assim o seu trabalho parece resistir à ideia de participação tão em voga nos anos $60^{137}$, como se o toque do público, o aspecto lúdico, ou o fato de o observador agir diretamente sobre a proposição do artista fosse o dado por excelência libertador e propiciador de uma participação criativa.

A despeito do desencontro entre o discurso de Flusser nos anos de 1970 e o trabalho de Schendel, na ocasião do lançamento do seu primeiro livro, Língua e Realidade, escrito originalmente em português e editado em 1963, o pensador e a artista parecem estar mais sintonizados. Nesse período, o diálogo entre Flusser e Schendel é mais preciso, e a distância entre as teses dele e o trabalho dela é menor.

A tese central do livro é a de que a língua é o cosmos, a ordem que organiza o mundo e isso será o fio condutor do autor na busca de desvelar sua estrutura. Sua premissa é a de que há uma identificação entre a estrutura do cosmos e a língua. Amplamente inspirado em

137 Em depoimento para o Departamento de Pesquisa e documentação de Arte Brasileira da Faap, em 1977, Mira Schendel se referiu ironicamente ao ideário da arte participativa do momento: "Surgiram os Toquinhos, os Discos, e aquelas tirinhas de acrílico [Transformáveis] que todo mundo achava que eram objetos faça-junto, brinque-junto, mexa-junto, destrua-junto." 
Heidegger, para Flusser, a língua é a realidade e ela, ao mesmo tempo, cria a realidade. A palavra é em grande parte a matéria prima do pensamento. Claro que há sensações que escapam à palavra como alguns cheiros, mas esses seriam apenas dados inarticulados e imediatos. Seriam dados brutos ou sensações brutas e desorganizadas. A realidade antes da linguagem é a da desordem, campo em que predomina o caos. É a língua que dá o estatuto de realidade para as sensações caóticas, é ela que organiza as sensações.

Pensar as inscrições que Mira Schendel faz em seus papeis como um modo de organização do mundo, ou de ao menos parte dele, pode ser revelador. Em muitas de suas séries de monotipias as letras acabam sendo deformadas não apenas para adquirirem maior ou menor presença, outro modo de estar presente na folha, mas também como ativadoras desse mesmo espaço em que estão inseridas. Isso acontece seja pela variação de tamanho de cada uma das letras, seja pela repetição da mesma palavra. Na monotipia em que aparece escrita duas vezes a palavra "ZEIT", na segunda vez a letra " $\mathrm{T}$ " é desenhada com uma linha mais espessa, mais pesada e que passa a intervir de modo mais incisivo no branco do papel, se diferenciando claramente dos outros sinais gráficos. Os dois " $Z$ " seguidos quase formam uma única estrutura em ziguezague e a duplicidade das letras, particularmente do "I", sugere uma linha pontilhada, ou seja, um modo de organização em que os elementos são distribuídos de acordo com o intervalo de sua ocorrência ${ }^{138}$.

Também os Datiloscritos de Schendel, desenvolvidos por volta de 1974, trazem a linguagem escrita literalmente como estruturadora do campo em que se apresentam. As letras formam blocos homogêneos, unidades isoladas que organizam plenamente a composição. A repetição, a proximidade, a distância, a variação,

\footnotetext{
138 Provavelmente, está no horizonte de Mira Schendel o mais importante trabalho de Martin Heidegger: Sein und Zeit, cuja primeira edição foi publicada em 1927.
} 
enfim, as relações que os blocos possuem entre si e com os vazios é que ordenam o universo que esses trabalhos criam. A regularidade e a integração dos elementos presentes nos Datiloscritos, mesmo quando eles não constroem uma frase com sentido preciso, revelam certa ordem do mundo em que foram concebidos.

Para Flusser, os dados brutos só podem ser apreendidos e compreendidos por nós por meio da língua. O que tornaria então os dados brutos inacessíveis diretamente. Assim, a língua aos poucos passa a ocupar o lugar dos dados brutos e suas regras internas são analisadas como a própria estrutura da realidade. A língua é também um dado bruto, na verdade o principal dado a ser estudado pelo autor. Como no mundo há uma multiplicidade de línguas, existiriam tantos mundos quanto são as línguas e formas de línguas. Claro que esses mundos não são isolados um dos outros, uma vez que há muitas raízes em comum entre as línguas. O autor divide em três grandes famílias as línguas: as flexionais, as aglutinantes e as línguas isolantes. Grosso modo, o primeiro grupo é formado pelas línguas em que palavras agrupadas formam frases/ pensamentos que se relacionam, nele estão, por exemplo, as línguas indo-européias. 0 segundo grupo, as aglutinantes, se organiza a partir de superpalavras que correspondem às nossas frases, e nele está a língua esquimó e mongol, entre outras. O terceiro grupo, o das línguas isolantes, consiste em poucos elementos que compõe um mosaico, nelas estão línguas como a chinesa.

Cada língua é uma espécie de cosmos e investigá-las é, portanto, o melhor modo para nos aproximarmos da realidade. Se cada língua é um mundo, a tradução entre elas adquire suma importância, mesmo que uma tradução completa seja rigorosamente impossível. Dentro de um mesmo grupo de línguas os mundos podem ser semelhantes, mas não são os mesmos mundos. Se não faz sentido a tradução sintática de um língua, por aproximação, devido às semelhanças ontológicas, é possível estabelecer equivalências. É a 
possibilidade de tradução entre as línguas, o que é possível pelo menos entre as línguas flexionais, que permite a intercomunicação de mundos. Traduzir é na verdade transitar de um mundo a outro. No momento em que o tradutor está formulando a sua viagem de um mundo a outro sempre existirá o risco de ele cair num abismo, momento em que ele está entre as duas línguas. Segundo Flusser, é da intercomunicação entre as línguas que se originou a civilização ocidental. Isso faz com que simultaneamente cada língua seja um mundo inteiro e que também cada uma delas possa incluir em seu mundo todas as demais.

Nos papéis de Mira Schendel é comum que várias línguas se misturem como o italiano, o alemão e o português, elas se intercalam e se comunicam de modo fluído. Não há rivalidade entre elas. Tudo se passa num território ambíguo em que uma língua pode englobar a outra ou manter a distância de códigos distintos. Não há hierarquia, nenhuma tem mais importância que a outra justamente porque cada uma tem um modo próprio de ser e regras próprias para articular a realidade.

O método usado por Flusser em sua empreitada, a saber, compreender a estrutura da realidade, é o de tentar se aproximar ao máximo de "uma ingenuidade em face da língua", que teria sido perdida ao longo da história da filosofia. Nesse ponto parece que Flusser e Schendel se aproximam bastante. Para isso, Flusser cita explicitamente o método fenomenologico de Husserl e faz referência a Epoché:

"À primeira vista, esse esforço é condenado ao fracasso, já que uma ingenuidade não pode ser conquistada. Entretanto, existe a possibilidade de pormos em parênteses os conhecimentos acumulados no curso da história, deixá-los em pendência, como que disponíveis para futura referência, e aproximarmo-nos da língua despidos desses conhecimentos. É uma possibilidade que exige disciplina mental violenta. Foi chamada por Husserl de fenomenologia. Graças a ela alcançaremos, conforme afirma Husserl, uma ingenuidade de segundo grau que nos capacitará a apalpar o centro, o eidos, da língua. Duvido que possamos manter essa 
violência contra nossa mente por muito tempo. Entretanto, o método fenomenológico será o ideal inalcançável, do qual tentarei me aproximar. ${ }^{1139}$

Flusser também recorre a outros filósofos contemporâneos para desenvolver seu estudo sobre a língua, como Heidegger e o primeiro Wittgenstein. Ele irá promover uma espécie de conversação entre os dois filósofos, mas uma conversação que será feita num "terreno neutro", que para ele é a língua portuguesa. Amar excessivamente a língua materna, diz Flusser, pode levar ao nazismo.

Heidegger, sobretudo por ter valorizado a ontologia da língua, está entre suas referências. Foi ele quem compreendeu que a linguagem tem uma dimensão ontológica e que não há Ser fora da realidade nem realidade fora da linguagem. Mas Flusser se coloca em oposição à violência praticada por Heidegger contra língua. O filósofo, em vez de se adaptar a ela, força a língua a se adaptar aos seus jogos de palavras.

Wittgenstein é, para Flusser, o pensador que mais se embrenhou nas profundezas da língua. Além disso, para ele, será importante o silêncio como nexo entre a língua a e realidade, tal como esboçado na proposição número 7 do Tractatus LógicoPhilosophicus ${ }^{140}$. Entretanto, é como se Wittgenstein se esquecesse

\footnotetext{
${ }^{139}$ Flusser, V. Língua e Realidade. São Paulo: Annablume, 2007, p. 36.

${ }^{140} \mathrm{Em} 1968$ o professor do Dep. de Filosofia da USP José Arthur Giannotti, publicou a primeira tradução em português do Tractatus Logico-Philosophicus, de Wittgenstein, pela editora Nacional. Houve uma polêmica no Suplemento literário de OESP, com direito a repica, após Flusser discordar da tradução muito técnica de Giannotti. Cf. "Wittgenstein traduzido?" Suplemento Literário, OESP, de 22/03/1969 com replica de Giannotti publicada em 12/04/1969. Vilém Flusser, talvez pelas suas posições políticas ambíguas e por estar vinculado ao Instituto Brasileiro de Filosofia, numa época de muitas polarizações ideológicas, era visto claramente como de direita, apesar de ser um judeu que fugiu do nazismo e que teve sua família assassinada pelas tropas de Hitler. Além disso, seu método não era visto como disciplinado, com a precisão e a fidelidade ao texto exigidos pelo Departamento de Filosofia da USP. Seu perfil era mais livre, de alguém que não tinha a pretensão de fazer historia da filosofia, de citar precisamente as fontes, mas sim de ser um filósofo original. Por isso, seus textos publicados na imprensa não eram vistos como filosofia pela USP, mas como textos de um pensador livre. Seu método de descrição dos fenômenos, sem uma teoria prévia para intuir a essência daquele fenômeno, pode ter colaborado para que sua recepção não tenha sido muito calorosa pelos
} 
que seus pensamentos também são resultados da língua em que são formulados, dirá Flusser. A sua crítica é a de que o filósofo alemão acaba usando a sua língua como se ela fosse a única, a língua, sem levar em conta a pluralidade de línguas em que ela se insere, e formulando com ela não uma filosofia, mas a filosofia. E isso faz com que ele simultaneamente subestime e valorize a língua excessivamente. Mas a questão central será a de que a filosofia, como uma disciplina reflexiva, não precisa ser necessariamente tautológica:

"O poder criador escapou, curiosamente, à observação
wittgensteiniana, tanto o poder criador da conversação em
geral como o poder criador da conversação reflexiva em
particular. Daí o pessimismo injustificado de Wittgenstein.
Ele não notou que a língua não é estática, mas é algo que
cresce e se expande, e que cresce e se expande graças aos
intelectos que participam da conversação."141

Wittgenstein não soube, conforme diz Flusser, compreender a extensão ontológica da língua, como se os dados brutos fossem algo extralinguístico, e com isso negou a realidade da língua e ignorou o valor criador da poesia. Em Língua e Realidade, o pensador investiga o que ele chamou de "estrutura ontológica das línguas", ou seja, a aproximação entre o significado da língua, ela própria uma realidade, com o seu sistema de referências, sua estrutura formal. O autor faz uma espécie de análise fenomenológica de quatro línguas em que possui fluência, o alemão, o inglês, o português e o tcheco, e mostrará que categorias como a de tempo ou mesmo a de realidade, mesmo que esteja presente nas quatro línguas, possui significados diferentes, variando de sentido de acordo com estrutura de cada uma delas. Do mesmo modo, as noções de atividade e passividade, ou

professores do Departamento daquele momento. Ainda que pese o fato de que ele tenha sido professor da área de filosofia da ciência, lotado na Escola Politécnica da USP e vinculado à FFLCH. Mas por não ter diploma universitário, por nunca ter se inscrito em curso de pós-graduação, e por não se apresentar após sua transferência para o Departamento de Filosofia depois da reforma universitária, seu contrato não foi novamente renovado depois de quatro anos, em 1971.

${ }^{141}$ Flusser, V. Língua e Realidade. São Paulo: Annablume, 2007, p. 86. 
objetividade e subjetividade variam de importância para cada um das línguas e fora das línguas flexionais elas não possuem significado. Substância, unidade e multiplicidade, causalidade, Ser também estão entre os conceitos que de acordo com a língua em que são pensados mudam seu peso, seu significado, ou seja, nenhum deles é uma categoria da razão pura.

O pensamento de Flusser deve bastante à Fenomenlogia do Espírito de Hegel, em especial a dialética hegeliana entre o público e o privado: perder o mundo ou se perder no mundo. Aquele que se fixa no espaço privado corre o risco de perder o mundo, enquanto a fixação no espaço público tende a provocar que ele se perca no mundo. Para Flusser a língua pressupõe inter-subjetividade, um subjetividade coletiva ou, ao menos, uma comunidade, mas o uso pleno da língua exige sempre um espaço público, a existência que se encontra no privado e que se estende no público.

Entretanto, dirá o pensador, os novos meios, as novas tecnologias podem levar a abolição dos espaços públicos. Isso é uma abolição da publicidade do espaço público em benefício de um espaço cada vez mais privado. Com a revolução no campo da comunicação as informações fluem diretamente do espaço privado para o público. Se por um lado os novos meios trazem benefícios há também esse grande perigo de o espaço público ser apenas o espaço em que cabos materiais ou imateriais atravessam. Todas as informações chegam diretamente ao espaço privado do receptor, ou seja, elas se tornam privadas. Com isso, o espaço público, e a própria noção de política, entraria em colapso. Em vez de frenquentar concertos o cidadão houve a música num disco, em vez de ir ao cinema vê o filme na televisão, em vez de estudar na universidade assiste aulas gravadas em sua própria casa e, do mesmo modo, escolhe os produtos que vai adquirir por uma tela de computador.

A estrutura tradicional da comunicação com emissor, transmissão e receptor, não seria mais adequada. Os novos tempos 
necessitam, diz Flusser já nos anos de 1980, de uma comunicação e de uma cultura em rede, em que cada um é simultaneamente emissor e receptor. Flusser irá fazer um grande elogio a simultaneidade e instantaneidade das conexões de cabos reversíveis, que teoricamente nos permitiriam estar presentes em todo lugar. Para ele a diferença fundamental entre a tele-presença e a presença física seria anulada, ambos seriam equivalentes, trata-se para Flusser apenas de uma questão técnica que o futuro resolveria.

A sua aposta na eliminação da dicotomia sujeito-objeto do conhecimento se dirigirá completamente para o campo da computação. A sua conclusão é de que se tornaria sem sentido a distinção entre o campo subjetivo e o objetivo e, pelo cálculo realizado pelas máquinas de computadores, sujeito e objeto se reuniriam em algo anterior a distinção deles. Para Flusser, a noção de corpo não parece ser fundamental para a eliminação da clássica dicotomia. Ele seguirá, em última instância, uma concepção moderna de máquina, há algo de ideal nela, uma vez que ela poderia se autoregular como um autômato. A máquina que ocupará o centro do pensamento de Flusser será o modelo e a condição de todos os objetos técnicos e, dado o seu caráter sistemático e normativo, adquire o status de paradigma da racionalidade. Para o pensador, a razão tem como modelo a máquina, que por sua vez poderia substituir o ser vivo, o homem e o pensamento humano. Até a escrita estaria em xeque a partir da invenção de programas formulados por linguagem matemática.

Em seu livro A escrita - Há futuro para a escrita?, Flusser irá investigar o que chamou de crise da escrita e a sua superação a partir das "máquinas pensantes", os computadores, as verdadeiras máquinas de escrever, as que possuem inteligência artificial. As pesquisas de Flusser se encaminham em sua obra madura para a investigação da fotografia, o que ele chamou de a Filosofia da caixa preta, que irá se desdobrar no trabalho o Universo das imagens 
técnicas: o elogio da superficialidade, que mais do que investigarem a fotografia abordam a proliferação das tecno-imagens, seus pontos, granulados e pixels, o que o afastará das questões que interessam a essa pesquisa, ao trabalho de Mira Schendel e a noção de corporeidade. 


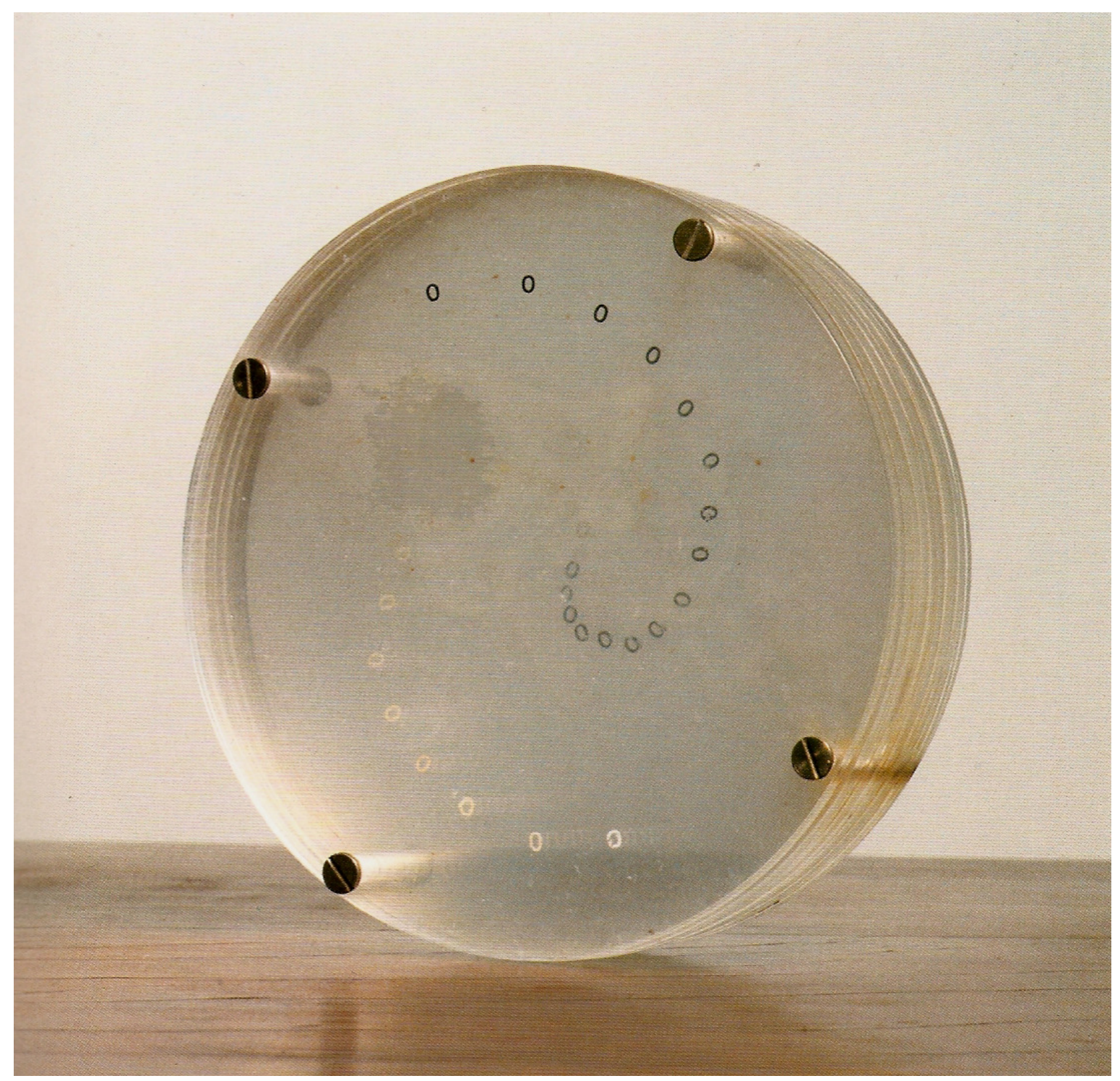

Sem Título, dec. 1970

Letraset entre placas de acrílico transparente, $18 \times 5,5 \mathrm{~cm}$ 


\section{Corpo e corporeidade}

"O pintor 'traz seu corpo' [...]. Com efeito, não vemos como um espírito poderia pintar. É emprestando seu corpo ao mundo que ele transforma o mundo em pintura. Para compreender estas transubstanciações, há que reencontrar o corpo operante atual, aquele que não é um pedaço no espaço, um feixe de funções, mas um entrelaçado de visão e movimento." ${ }^{142}$

Merleau-Ponty

"Para mim, segundo o meu modo de ver as coisas, eu acho que nunca podemos escapar desse lado da percepção e da corporeidade. É porque em qualquer tipo de arte, mesmo na arte mais abstrata ou na arquitetura, nós temos sempre essa segunda categoria da corporeidade e há sempre, vamos dizer, essa corrente ou sugestão de movimento fundamentalmente ligado a corporeidade que vai dialogar com a disposição corpórea de cada um, tá certo? Erradíssima a arte que cobre completamente essa textura, este movimento da mão. Dou a maior importância que seja assim manual, que seja artesanal, que seja vivenciada, que saia assim da barriga." ${ }^{\prime 143}$

Mira Schendel

142 Merleau-Ponty, M. O olho e o espírito. op. cit. p. 278

143 Schendel, M. "Mira Schendel, pintora", Entrevista para Jorge Guinle Filho. Interview, São Paulo, jul. 1981, p. 54. 
O trabalho de Mira Schendel está impregnado pela noção de corpo, não do corpo como objeto, que simplesmente ocupa um lugar no espaço, nem do corpo como algo que pode ser explicado pela fisiologia ou compreendido como apartado da mente ou do pensamento, como se ele fosse uma instância exterior ao sujeito, mas do corpo como campo ambíguo em que objetivo e subjetivo coexistem. $O$ interesse da artista é explicitado tanto em seus escritos, nas suas entrevistas ou conversas com o fenomenólogo Hermann Schmitz, da Universidade de Kiel, como também em muitos dos seus trabalhos. Será justamente a noção de corpo, assim como o par visível e invisível, que irá proporcionar a tentativa de superação do dualismo clássico.

Embora referências de Schendel aos filósofos franceses sejam raras, e não tenhamos encontrado em seu arquivo citações diretas a Merleau-Ponty, há em seu diário uma breve citação a Jean-Paul Sartre em relação à objetivação do outro. Interessante notar que a artista, assim como Merleau-Ponty, irá negar explicitamente a ideia de redução do outro a uma coisa. Em todo o trabalho de Schendel está presente o respeito ao outro e a recusa em tratá-lo como objeto ou como alguém que deve simplesmente executar uma ação já previamente premeditada pelo seu trabalho. Em seu diário ela escreveu:

"O inferno é o outro, dizia Sartre ${ }^{144}$. Na medida que me objetiviza. Obviamente sujeito e objeto são o mesmo. Eu sou o meu corpo. Morta sou só objetivada. Deixei de ser eu. Qualquer uso do outro como um meio - não deixar o outro é reduzi-lo a uma coisa. ${ }^{145}$

Merleau-Ponty, em O Visível e o invisível refuta a tese de Sartre sobre o outro, que parece redundar num solipsismo, na redução do

\footnotetext{
144 Trata-se de uma referência ao famoso diálogo da peça de Sartre, J-P. Entre quatro paredes. São Paulo: Civilização Brasileira, 2007.

${ }_{145}$ Caderno inédito e sem data. Como nas páginas seguintes ela cita o funeral de Tancredo Neves, provavelmente podemos datá-lo de 1985.
} 
outro ao que há de visível em sua situação. Para Sartre, a relação que o eu estabelece com o outro é um fato puro que em nada modifica o modo como eu vejo a mim mesmo. Ou seja, filosoficamente, para Sartre não há uma abertura ou uma experiência do outro:

\footnotetext{
"No final das contas, portanto, a relação permanece entre eu como nada e eu como homem, não trato com os outros, trato no máximo com um não-eu neutro, negação difusa do meu nada. ${ }^{146}$
}

O olhar do outro sobre mim e sobre o meu corpo não acrescenta qualquer nova dimensão ao meu universo, uma vez que já sei de antemão que em torno de mim há um fora em geral, e o olhar de outro sobre mim apenas confirma o que já era sabido, a partir de dentro, por mim. O outro para Sartre é apenas um duplo, ele não é aquele que me revela quem eu sou, mas um duplo que pode ser compreendido como o "inferno", aquele que me aniquila e me transforma em objeto. O outro nunca será penetrado pelos meus olhos porque ele é quase um objeto para mim também. O invisível, ou o que se passa na consciência do outro, jamais se mostraria, nunca se tornaria visível.

Entretanto, a experiência da visão pode nos levar a resultados concretos, pois com ela saio do meu interior, do meu reduto invisível, para encontrar o mundo e o outro lá onde ele está. 0 mundo e o outro são aquilo mesmo que eu vejo e do modo como eles se mostram para mim. Não há oposição ou contradição entre quem vê e quem é visto. Há cumplicidade entre as coisas e a visão, porque tudo se passa como se meu olhar acariciasse as coisas e sentisse os seus próprios contornos e texturas. Segundo Merleau-Ponty:

"A analítica do Ser e do Nada é aquele que vê esquecendo-se que possui um corpo e de que aquilo que vê está sempre sob o que vê, tentando forçar a passagem em direção ao ser puro e ao nada puro, na medida em que se instala na visão

${ }^{146}$ Merleau-Ponty, O visível e o invisível, op. cit. p. 75. 
pura, que se faz visionário, mas que é remetido à sua opacidade de vidente e à profundidade do ser". ${ }^{147}$

O ser para Merleau-Ponty não é positividade, pois ele sempre me escapa, ele não é plano, é profundidade e, portanto, não é plenitude, mas abismo que se desvenda ocultando-se. Tudo que pode ser visto possui também uma lacuna, uma dimensão invisível que sustenta por dentro o visível. Por isso, a visão não pode ser uma visão distante de sobrevôo, isso impossibilitaria o verdadeiro encontro com o outro. Esse olhar panorâmico, olhar do alto que domina tudo, tende a transformar o outro em coisa, em manequim. Somente de perto a visão deixa de ser solipsista, porque de perto o olhar do outro invade meu campo de percepção e as fronteiras de meu corpo. Só há encontro verdadeiro com o outro quando ele lança seu olhar sobre mim e é esse olhar que faz com que eu sinta que meu corpo é visível. O olhar do outro pode atravessar meu corpo e romper com o solipsismo ou com a dicotomia do "Para-si" e do "Para Outrem". Ou seja, o meu ser para mim se torna visível ao outro, havendo uma espécie de interseção entre o meu universo e o do outro, passagem do outro em mim e de mim no outro.

Já para Schendel, segundo anotação de seu diário, o corpo aparece como o lugar absoluto do eu e é apenas dissociável do eu na morte:

"'O lugar absoluto do eu é o lugar absoluto da corporeidade. E não o lugar relativo do corpo objetivado. Alguém que julga me conhecer por dentro e por fora me objetiva totalmente: como um cadáver.' Esta seria uma total e absoluta emancipação pessoal." 148

Não se trata, portanto, de afirmar que exista uma pura transparência entre o eu e o outro. Para Merleau-Ponty, de algum modo o outro permanece invisível, inalcançável, mesmo diante de um olhar direto há algo de impenetrável em mim e no outro. Se minha consciência

\footnotetext{
${ }^{147}$ Idem, ibidem. p. 81.

148 Schendel, diário inédito.
} 
não é transparente para mim mesmo, não seria para outro, mas há um mesmo mundo onde coexistimos e nos relacionamos. Mesmo que o outro permaneça em parte invisível, inalcançável, posso ver seu corpo ou ouvir suas palavras ao mesmo tempo em que seu corpo ou suas palavras sejam também o avesso de mim, tanto quanto eu sou o avesso do outro, uma ausência visível e audível. O corpo está nessa zona ambígua, numa espécie de interseção entre o que eu vejo e o que o outro vê, ou entre o visível e o invisível. Merleau-Ponty se refere ao corpo como reflexionante, "o homem como espelho para o homem"149, e o corpo como lugar da metamorfose do vidente e do visível. Imerso no mundo da visibilidade, meu corpo é um visível que vê. Portanto, eu sou um vidente que se aproxima do mundo pelo olhar. Meu corpo pode olhar todas as coisas e ser visto por elas, ele é o que me abre para a experiência com o mundo.

Para Schendel, em manuscrito encontrado em seu arquivo, é indispensável na arte a vivência corpórea:

\footnotetext{
"O fundamental em arte não é a comunicação.

O fundamental em arte não é a informação.

O fundamental em arte não é a inovação.

O fundamental em arte é a vivência da corporeidade. As artes e em particular as artes plásticas visam à vivência corpórea. Entenda-se por corpóreo não a vivência dos cinco sentidos, mas toda a percepção que se apresenta ao corpo. ${ }^{150}$
}

Essa ênfase no corpo, na sensibilidade corpórea e na percepção é o que permite a própria experiência, saída de mim em direção ao mundo e reencontro comigo mesmo. E a artista reconhece que quando produz um objeto, ela lança no espaço do outro algo que proporcionará novas situações e experiências. O fundamental é a vivência da corporeidade porque ela é "o sustentáculo de todas as

\footnotetext{
${ }^{149}$ Merleau-Ponty, Olho e o Espírito, op. cit. p. 283.

150 Schendel, Manuscrito inédito e sem data, redigido a mão e com várias rasuras feitas pela própria artista.
} 
dimensões humanas"151. Schendel se mostra atenta aos trabalhos teóricos de contemporâneos seus e aborda também e o sentido político do corpo:

\begin{abstract}
"Numa época em que Chomsky provou que as transformações de estrutura profunda e estruturas de superfície se fazem segundo regras universais, numa época em que Strauss nos mostra a universalidade das regras de transformação da natureza em cultura e em que Piaget obtém resultados análogos trabalhando com a lógica, parecenos muito razoável supor a universalidade das regras que transformam a vivência profunda inarticulável do espaço em vivências individuais e coletivas dentro de um certo destino. [...] A fluidez e historicidade do destino (individual ou coletivo) nos leva cada vez a distintos produtos dessa transformação. Creio que essa seja uma proveitosa maneira de se enfocar o problema do novo em arte. [...] Ao levar o outro a consciências de novas experiências corporais estamos sem dúvida modificando radicalmente sua configuração de mundo e se isso não for uma atitude política ignoro-o o que seja."152
\end{abstract}

Essa afirmação da transformação da vivência profunda e inarticulável do espaço em novas vivências individuais ou coletivas se relaciona diretamente com a noção de advento formulada por Merleau-Ponty. 0 artista não se guia por um modelo prévio, mas é de um fundo invisível e silencioso que retira ou elabora um visível ou um dizível. Por isso, ele vai à origem ou ao inarticulável, como nomeou Schendel, e pode nos ensinar o que é ver. Esse fundo inarticulável que nos leva sempre ao novo é também a retomada de uma tradição, da percepção e da obra de outros artistas e, ao mesmo tempo, é instauração de uma nova tradição, uma abertura na história, instituição de novos sentidos, que por sua vez podem ser retomados numa nova expressão, por outros artistas que irão recolher o excesso de sentido do visível, o invisível percebido como falta. Daí o destino interminável da arte e a própria impossibilidade de um progresso linear ou de uma história empírica de acontecimentos. $O$ advento não

\footnotetext{
${ }^{151}$ Idem, ibidem.

${ }^{152}$ Idem, ibidem.
} 
é algo fechado em si mesmo, como um acontecimento empírico que poderia ser localizado dentro de uma série definida, a partir de uma sucessão, ou de uma cronologia; o advento é aquilo que está por ser realizado, é o excesso de sentido que transborda de uma obra, é o destino que há de vir por mais incerto e indeterminado que ele seja, é a própria posteridade de uma obra. É o que no interior de um trabalho solicita outro trabalho, outra ação significadora, é a promessa de que novos acontecimentos virão.

A arte, assim como a ação política, será duradoura se for fecunda, ou seja, se tiver a capacidade de gerar outros trabalhos ou outras ações, que serão suscitadas pelo excesso de sentidos, sobre os sentidos já sedimentados na cultura e também pela percepção de uma falta que deve ser completada, uma carência ou lacuna que deve ser preenchida, portanto, que seja uma espécie de matriz de acontecimentos.

O par falta e excesso de sentido ou visível e invisível estão presentes, por exemplo, no trabalho de Schendel da polemica $10^{a}$ edição da Bienal Internacional de São Paulo, a Bienal do boicote. Ela participou com Ondas paradas de probabilidade, de 1969, que como a própria artista definiu em suas anotações, lida com a "visibilidade do invisível". Coincidentemente, algumas das reflexões presentes no livro póstumo de Merleau-Ponty, o visível e o invisível, iluminam bastante a discussão de seu trabalho. O par visível e invisível, que substitui a oposição figura e fundo tão presente na Teoria da Gestalt, se mostrará mais potente na tentativa de superação do dualismo clássico. E foi esse mesmo caminho que coincidentemente Schendel seguiu.

O trabalho feito na Bienal consiste num ambiente de centenas de fios de náilon pendurados do teto ao chão no amplo espaço do pavilhão da Bienal que obedecem a uma estrutura geométrica. Numa das paredes, uma placa apresenta um trecho bíblico, extraído do 
Livro dos Reis I, $19^{153}$, sobre o silêncio de Deus. Ter aceitado expor numa Bienal, que devido ao Golpe Militar no Brasil e da violenta repressão depois de 1968 foi boicotada por artistas do mundo todo, pode ter sido uma decisão controversa, mas entender esse momento também é compreender a complexidade do trabalho da artista. Se para Schendel uma atitude política era proporcionar novas experiências corporais, como vimos em seu texto, um trabalho que deve ser penetrado pelo corpo do visitante e que fala sobre o silêncio de Deus num momento de catástrofe é, além de um manifesto político, um trabalho com espessa dimensão filosófica. Em seu diário, Schendel fez a seguinte anotação:

"Hoje, inauguração da X Bienal. Ganhei para o Brasil uma
menção honrosa. [...] A 'visibilidade' do invisível. O 'silêncio
visual'. 'Esta experiência tende ao a-racional, além do
irracional e do racional. [...] Com o trabalho da Bienal (O
'sussurrar do invisível') talvez inicie uma fase de maior
silêncio. E também nos desenhos. Escutar (também o
silêncio)."154

Schendel apresentou uma obra quase invisível, num momento em que o silêncio ou o invisível parecem ser mais eficazes que um grito desesperado e a evidência da visibilidade. Mas ao contrário de seus colegas, que optaram pela ausência e pela total invisibilidade, ao recusarem expor seus trabalhos, Schendel se situa entre o visível e o invisível. Essa estratégia faz com que o trabalho possa ir além da questão política do momento. Trata-se da construção de um espaço ambíguo, que se dirija para um corpo calado, para uma experiência muda e para além ou aquém da razão. Parece existir aqui uma noção alargada de razão, chamada pela artista de "a-racional", e que é

\footnotetext{
153 O trecho diz o seguinte: "Um grande e impetuoso furacão fendia as montanhas e quebrava os rochedos diante de lahweh, mas lahweh não estava no furacão; e depois do furacão houve um terremoto, mas lahweh não estava no terremoto; e depois do terremoto um fogo, mas lahweh não estava no fogo; e depois do fogo o murmúrio de uma brisa suave. Quando Elias o ouviu, cobriu o rosto com o manto, saiu e pôs-se à entrada da gruta. Então, veio-Ihe uma voz, que disse: "Que fazes aqui, Elias?"

${ }^{154}$ Schendel, diário inédito manuscrito com caneta colorida e em formato menor.
} 
anterior ao pensamento racional, o que Merleau-Ponty chamou de pré-reflexivo.

Nesse sentido, o ambiente opaco e transparente de Ondas paradas de probabilidade, retira sua força do invisível e do silêncio que sustentam a visibilidade e a fala. $O$ trabalho recolhe da fonte impalpável do mundo, do fundo originário em que se apóia toda invenção, do invisível que estrutura e torna possível um visível, seu sentido inédito. Por isso podemos dizer que ele é um trabalho instituinte, porque institui novas significações ao lidar com a ambiguidade do visível e o invisível.

A noção de transparência, presente em Ondas Paradas de probabilidade, é recorrente na obra de Schendel e se desdobrou em outros trabalhos. Desde as monotipias a transparência do papel era explorada. Mas quando a artista descobre o acrílico ${ }^{155}$, a transparência ganha um corpo e adquire outras dimensões. Os Objetos Gráficos, grandes placas de acrílico que envolve a frente e o verso de papéis trabalhados graficamente, exploram as duas faces do plano. Segundo a lúcida consciência de Schendel, o acrílico:

"a) torna visível a outra face do plano, e nega portanto que o plano é plano. b) torna legível o inverso do texto, transformando o texto em antitexto. c) torna possível uma leitura circular na qual o texto é centro imóvel, e o leitor o móvel. Destarte o tempo fica transferido da obra para o consumidor, portanto o tempo se lança do símbolo de volta para a vida. d) A transparência que caracteriza o acrílico é aquela falsa transparência do sentido explicado. Não é a

$155 \mathrm{Em}$ depoimento para o Departamento de Pesquisa e documentação da Arte Brasileira da Faap, em 19/08/1977, a artista narrou a descoberta desse material: "Nas minhas andanças pelo bairro, nos passeios de tarde - toda fabriquinha me atrai, seja ela de metal, de vidro, ...qualquer material me atrai, o trabalho manual me atrai, eu vou dizer assim, tudo aquilo que a gente faz as mãos - e encontrei uma fábrica onde faziam luminosos (...). Entrei lá, pedi permissão, disse que era artista, meu único jeito de poder começar a mexer com aquilo, se me deixavam olhar os refugos. E me deixaram. 'Deixa aquela velha louca, deixa ela fazer. Não está estorvando ninguém'(...) olhando aquilo foi surgindo a idéia de misturar aquele papel transparentíssimo, com aquele acrílico também transparente, branco, obviamente." 
transparência clara e chata do vidro, mas a transparência misteriosa da explicação, de problemas. ${ }^{156}$

Assim, a ideia de transparência dos acrílicos, presente nos Objetos Gráficos, está longe de uma clareza ou limpidez que possa resolver qualquer dúvida. Ao contrário, sua qualidade está no mistério e na ambiguidade. Neles, o desenho ganha corpo, se situa no espaço tridimensional com uma presença mais firme, de um modo que o vidro não permitiria. Além disso, a simultaneidade entre o avesso e o direito traz outra noção de tempo, diferente do tempo dos cadernos, em que uma sequência de letras gira e se desdobra no espaço, vistas por vários ângulos distintos e que trazem o tempo para dentro de si. Agora, o tempo é aquele do próprio vidente que circula em torno do trabalho, um tempo que atravessa o desenho e se desdobra no caminhar do público que gira ao redor do trabalho, ou seja, um tempo que é vivido pelo corpo e, portanto, é experiência direta.

Os Toquinhos são desdobramentos mais espessos dos Objetos Gráficos. Numa placa de acrílico transparente, uma série de retângulos ou círculos com mais espessura, também de acrílico transparente, são colados. Entre eles há letras adesivas e fragmentos de papéis prensados, como se estivessem organizados numa coleção que flutua no espaço. Como vimos, a caligrafia e com ela o gesto da escrita, foi sendo substituída pelo corpo da letra adesiva e pelo aspecto gráfico. Os Datiloscritos feitos nos anos de 1970 já mostravam essa possibilidade.

Dentre os trabalhos em que a transparência é problema central, os Discos são os que mais exploram a sucessão de camadas. Neles uma série de placas, cada uma com uma letra adesiva colada em sua superfície, é sobreposta, criando uma complexa noção de profundidade que se mescla com o espaço exterior. Mesmo que não

156 Schendel, uma folha de papel sem título, datilografada e não assinada, encontrada em seu arquivo. 
fosse a intenção da artista criar um objeto, alguns de seus trabalhos foram recebidos desse modo nos anos de 1970.

\begin{abstract}
"Eu nunca me propus à escultura como escultura, nem ao objeto como objeto. (...) tanto assim que quando eu ganhei, acho que em 1975, o prêmio pelo melhor objeto do ano, fiquei estupefata. Porque eu achava que estava fazendo qualquer coisa, mas nem tinha ventilado propriamente a idéia do objeto. Ele surgiu de uma problemática da transparência, e não do objeto, não é o caso. Mas ele não surgiu como escultura, como coisa tridimensional, mas como transparência." ${ }^{157}$
\end{abstract}

Esse "objeto" cilíndrico, apesar da aparente leveza, de não necessitar de uma base porque pende do teto, enfim, de estar quase liberto de sua massa corpórea, é menos um corpo totalmente transparente ao olhar, como se fosse integralmente perceptível por todos os lados simultaneamente, como um geômetra conhece as seis faces de um cubo, que uma interrogação sobre a própria impossibilidade de uma visão totalizadora. Mesmo que minha visão, como a luz, atravesse os Discos, ainda há um dentro e um fora, mas um dentro visto de fora e o fora de dentro. Um se confunde e se diferencia do outro do mesmo modo como às vezes eu me confundo com a minha imagem num espelho, esse objeto diferente de mim, mas que me revela quem sou. A transparência revela o próprio enigma da visão: "o interior do exterior e o exterior do interior, que a duplicidade do sentir torna possíveis", tal como formulou MerleauPonty. ${ }^{158}$

Os Discos, como alguns Cadernos de Schendel feitos em papel vegetal, trazem tanto a questão da transparência como a do movimento circular, que apesar de sugerir a marcação de um relógio de ponteiro, pressupõe uma temporalidade imensurável, em que antes e depois, atrás e frente, ou o passado e o futuro convivem como simultâneos e indiscerníveis. Mas essa compreensão do tempo

157 Schendel, Depoimento para o Departamento de Pesquisa e documentação da Arte Brasileira da Faap, op. cit.

${ }^{158}$ Merleau-Ponty, O Olho e o Espírito. op. cit. p. 280. 
não se dá no campo das ideias ou no plano conceitual e sim diretamente na experiência com o trabalho. 


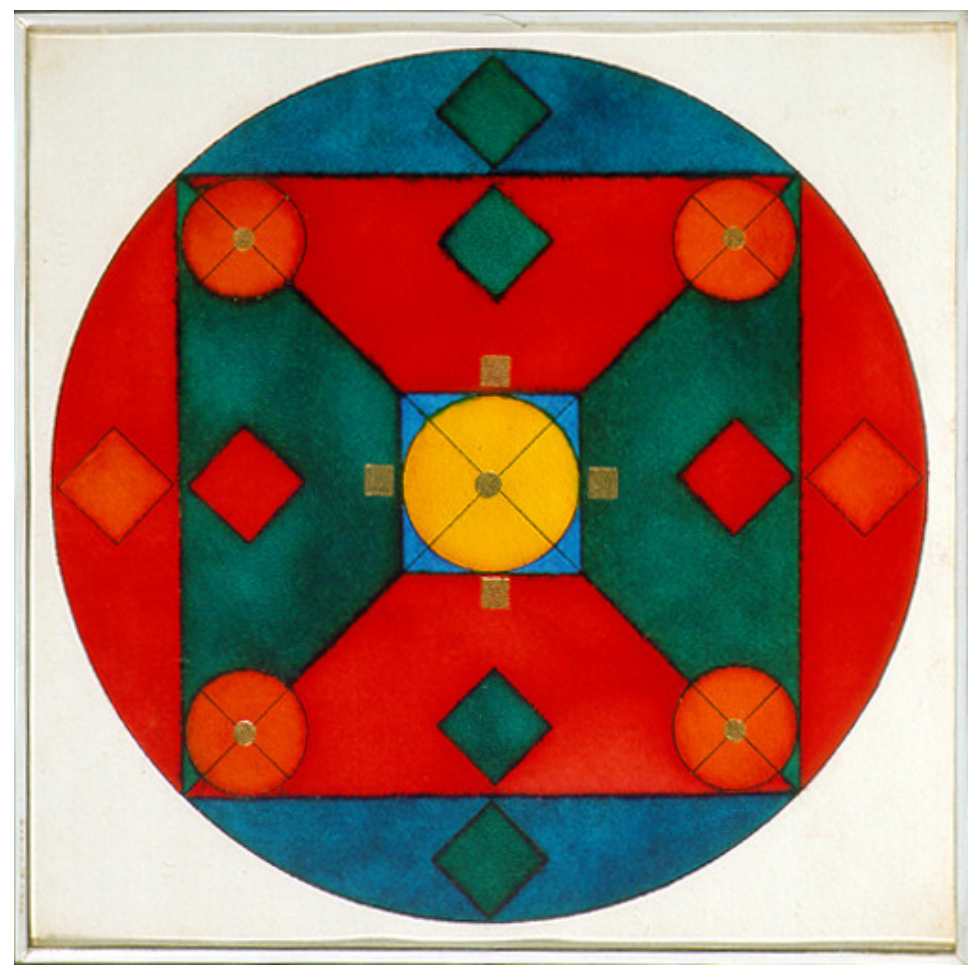

Sem Título, 1975

Ecoline e têmepera dourada sobre papel, $17,9 \times 17,8 \mathrm{~cm}$ 


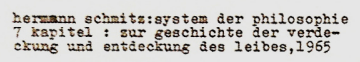

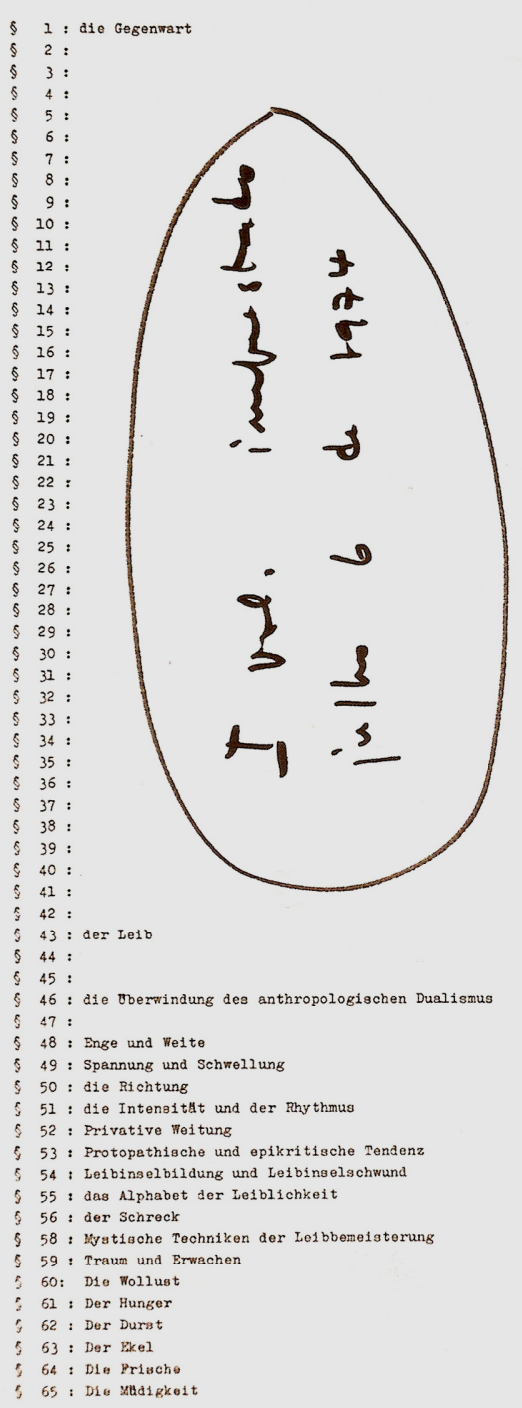

Datiloscritos, 1974

Datilografia, letraset e caligrafia sobre papel, $50,8 \times 37 \mathrm{~cm}$ 


\section{Diálogos livres com Hermann Schmitz}

"Posso superar o dualismo, mas não o posso aniquilar." ${ }^{159}$

Mira Schendel

O interesse pelo pensamento filosófico acompanhou todo o percurso de Schendel. Em um trabalho de sua fase madura, um Datiloscrito de 1974, ela já havia citado a obra System der Philosophie ${ }^{160}$, do fenomenólogo alemão, com quem entraria em contato direto cerca de dois anos depois. A referência a Schmitz foram frequentes em suas falas públicas, geralmente a respeito da noção de corporeidade e da superação do dualismo clássico. Em seu diário, Schendel arriscou traduzir fragmentos da obra de Schmitz. Ela se interessou pela fenomenologia de Schmitz, que ao contrário da obra de Merleau-Ponty, vai se distanciar da metafísica. Schendel irá também relacionar livremente a obra do filósofo com o budismo, com o oráculo chinês I Ching e com o pensamento de Jung.

Em determinado momento de um de seus diários, Schendel confessa que sua inquietação filosófica, assim como a falta de pessoas com quem pudesse dialogar sobre o tema, a levou a fazer uma chama internacional num momento em que elas eram mais raras e difíceis de serem completadas. Na conversa que teve com Schmitz tratou da superação do dualismo e em seguida refletiu sobre a nova fenomenologia:

\footnotetext{
"Infelizmente tive que admitir (telefonei anos atrás para a Alemanha para dizer isto para Schmitz) que não vejo como superar o dualismo. Concordou. Anos depois o admitiu abertamente - creio no último volume. [...]

Schmitz refundamenta a antropologia. A nova fenomenologia. A grande piada é que sempre estaremos
}

\footnotetext{
${ }^{159}$ Schendel, Diário inédito.

160 Schmitz, Hermann. System der Philosophie. Tomo I: "Die Gegenwart". Bonn: Bouvier, 1964.
} 
onde aqui e agora estivermos. 'O que não está aqui não está em lugar nenhum'. Isto é o budismo tântrico. Isto vale para nós, para formiga, para a ameba." 161

Schmtiz, talvez se referindo ao telefonema de Schendel ou a outros diálogos que tiveram, lembrou que: "certa vez ela disse que Ihe tinha proporcionado um grande alívio eu ter dito que a superação do dualismo não seria fácil."162 De todo modo, a conclusão por parte da artista sobre a impossibilidade de superação do dualismo subjetivo versus objetivo passa necessariamente pela compreensão da noção de corpo. Esse problema foi perseguido e investigado pela artista ao menos desde os tempos de suas primeiras monotipias e ela encontrou em Schmitz o seu grande interlocutor. Em seu diário, Schendel elaborou a oposição entre "espiritualismo" e "materialismo" como superável apenas no momento em que não há reflexão:

\footnotetext{
"Não é tão consolador e alentador assim alimentar a imagem de um princípio 'espiritual' contido em nosso corpo, ou em luta com nossa matéria. Este não passa de dualismo. Mas outra ilusão seria a da absoluta unidade. A reflexão e o pensamento a impedem. Esta unidade é só vivenciada no orgasmo e no sofrimento físico. Noutros termos eu diria: quando não há reflexão e pensamento."163
}

Por meio do raciocínio ou do pensamento racional essa superação parece claramente impedida. É apenas no extremo prazer ou sofrimento que isso se dá. Essa concepção foi formulada por Schmitz, que enfatiza o medo e a dor como o momento de estreitamento do espaço corpóreo, de aperto absoluto, e o momento de êxtase ou de sono como alargamento da noção do corpo. Schmitz, em entrevista para Geraldo Souza Dias, usa a noção de Leib para formular a superação do dualismo:

${ }^{161}$ Schendel, Diário inédito da segunda metade da década de 1980.

162 Dias, Geraldo S. "O corpo em Mira - entrevista com Hermann Schmitz". Novos Estudos Cebrap, São Paulo, n. 74, 2006.

${ }^{163}$ Schendel, Diário inédito. 
"A superação do dualismo pelo conceito de Leib pode ser entendida do seguinte modo: O homem normal de hoje, o homem das ruas entende-se dualisticamente, ou seja, sua autocompreensão experimenta uma cisão, de um lado seu entendimento do mundo, de outro, o de si mesmo. Se the perguntarmos sobre seu entendimento de mundo, ele fala de galáxias e átomos, na linguagem explicativa da ciência. Se Ihe perguntarmos sobre seu auto-entendimento, ele fala então sobre corpo e alma. Estes dois entendimentos absolutamente não se encaixam, mesmo que ele ainda possa situar o corpo entre átomos e galáxias. Mas assim procedendo, ele o alienou completamente, transformou-o num objeto de construção conceitual científica, sem relação alguma consigo mesmo e com aquilo que ele sente dentro de si. E a alma então, esta fica totalmente à margem. Ele não pode de nenhum jeito aproximá-la deste entendimento de mundo. Essa alma é algo muito obscurantista, pois não podemos tocá-la, e nem relacioná-la com um corpo que, por sua vez, acreditamos poder pegá-lo, embora o que se entende aqui também seja algo totalmente alienado, pois ele se tornou, um objeto da ciência, de teorias altamente complicadas.

E agora chegamos ao conceito de Leib, ao território objetivo daquilo que se pode sentir no próprio corpo. Encontramos então, em lugar do que seria esse corpo alienado, algo concretamente perceptível, concretamente sensível, que também é espacial, que também é aqui e agora, que não é nem alienado, como o corpo da ciência, nem enigmático e fantasmagórico como a alma ou o espírito. Tal conceito nos fornece uma base, podemos acompanhar seus fenômenos, podemos comprová-los. A partir dele, podemos construir uma ligação para tudo que de outro modo permaneceria encapsulado - como a alma e o espírito - até mesmo para algo transcendente. Pois tudo isso pode agora ser entendido conjuntamente sobre 0 plano básico deste sentir 'corpóreo'[leibliches Spüren]. Ele não é exatamente o corpo da ciência trazido para um entendimento fenomenológico, mas algo em substituição do corpo estranho da ciência, tão ou ainda mais concreto do que ele, que se pode determinálo, trazê-lo para junto do ser humano, de modo que se possa dizer com toda certeza, este é o ponto de apoio inicial no aqui e agora, onde estou de fato. E aquilo que existe além de mim, se eu me estender para além deste aqui e agora, com minhas lembranças, expectativas e fantasias, que partem deste mero sentir corpóreo, tudo isso posso agora situar numa relação compreensível a partir deste Leib." ${ }^{164}$

\section{O conceito Leib ${ }^{165}$, para Schmitz, é algo que rompe com o que ele} identifica como sendo a compreensão do corpo pelo senso comum. $O$

\footnotetext{
164 Dias, Geraldo S. "O corpo em Mira - entrevista com Hermann Schmitz". op. cit. 165 Apesar de o pesquisador Geraldo Souza Dias afirmar que "aquilo que o corpo sente", para Merleau-Ponty, "se esgota no perceber-se ou no movimentar-se" [Dias, G. S. Mira Schendel do Espiritual à corporeidade, op. cit. p. 165.], jamais
} 
homem contemporâneo se vê apartado do mundo, como se seu corpo pudesse ser tratado do mesmo modo que a física trata a matéria do universo e, principalmente, a partir da dicotomia entre matéria e alma. Nessa cisão, a alma é o lado obscuro do homem e teria uma relação apenas indireta com o corpo. Ele identifica uma espécie de alienação do corpo, operada diretamente pelo pensamento objetivo da ciência, que exclui o aspecto impalpável do corpo como se ele não tivesse relacionado diretamente com a experiência cotidiana. O Leib, como o corpo percebido imediatamente pelo sujeito, diz respeito ao corpo sentido do interior, concretamente, e não apenas pelos sentidos. O corpo mais que ocupar um lugar no espaço é o próprio espaço e jamais poderia ser reduzido a uma coisa, a um objeto da investigação científica. Do mesmo modo não seria possível situá-lo no campo abstrato, fictício e enigmático do espírito, como algo fantasmagórico em que tudo pode ser projetado, mas como algo indissociável do homem, ligado ao aqui e agora. É da noção de Leib que surge o espaço, mesmo o espaço da matemática e da física são derivações do espaço corpóreo.

"O Leib entra então em cena no lugar do corpo, para torná-lo
mais vivo e mais concreto, pois este corpo já tinha sido
quase que confinado no papel de mera coisa pensante, que
não mais podia ser entendido nem teoricamente, nem aferido
por instrumentos. E esta seria de fato a cura do dualismo.
Pois o corpo, infelizmente, não podemos abarcar com o meu
método, já que a ciência nos distanciou tanto dele, ficou
como que marginalizado. Por isso, podemos substituí-lo no
papel daquilo que o homem imaginou para entender-se
enquanto um concreto aqui e agora. Não queremos
absolutamente sacrificar o corpo da ciência, pois percebemos
nele muitas vantagens. Queremos continuar a nos servir da
técnica, mas não podemos entender a nós mesmos dentro

poderíamos reduzir a amplitude da noção de corpo numa filosofia em que ele tem importância central. O Leib de Husserl, que Schmitz irá recuperar e retrabalhar, deu antes origem ao que Merleau-Ponty chamou de Carne, que por sua vez surge da noção merleau-pontiana de la Chair. Carne é a polpa do mundo, equivalente ao termo "elemento" (terra, ar, água, fogo) da filosofia antiga e onde se entrelaçam os opostos. Carne é uma espécie de interioridade sensível: "Trata-se da experiência da simultaneidade de presença e ausência, visibilidade e invisibilidade, perfeição e inacabamento, totalidade e abertura, tecido conjunto e diferenciado do mundo, experiência que foi sempre recalcada pela filosofia que não podia, então, nomeála." Chaui, M. Experiência do Pensamento, op. cit. p. 45. 
dela. E então surge algo, que podemos considerar de fato concreto, que é este 'corpóreo' [Leibliches]. Não apenas o Leib, como eu o sinto, mas também o 'corpóreo', aquilo que percebo. Não é exatamente o que vejo, também não é o corpo da ciência, mas algo por meio do qual eu estou ligado em comunicação 'corpórea' [leibliche Kommunikation] através de qualidades associativas, sugestões de movimentos e caracteres sinestésicos que ocorrem sensorialmente. Existem, portanto todos esses caracteres expressivos, como também as situações e as impressões que se tem, não se permanece apenas naquilo que se sente no próprio Leib. Então reencontramos a possibilidade de entendermos conceitualmente o processo concreto da visão do cotidiano que estava deslocado, por um lado pela ciência, e por outro também pela teologia e seus produtos derivados, como a filosofia antiga que nos serviu até aqui para que depositássemos uma enorme quantidade de experiências de vida nesse recipiente que chamamos de alma." 166

Sem negar os incríveis descobrimentos da ciência, cuja técnica gerou enormes avanços para a sociedade contemporânea, Schmitz mostra as dificuldades do homem se identificar com esse corpo tal como descrito e analisado pela ciência. Em seguida, depois de apresentar o que chama de corpóreo, ligado à percepção concreta, e que o levaria à superação do dualismo, Schmitz cita explicitamente Merleau-Ponty como o filósofo do século XX que abordou diretamente a noção de Leib, de corpo vivido, e corpo como abertura para o mundo.

\begin{abstract}
"Eu considero isso a superação do dualismo, e espero poder realizá-la fenomenologicamente. Nesse ponto, sou bastante cauteloso, para não ser subestimado. Existem várias tendências da filosofia deste século, que tratam enfaticamente do corpo [Leib]. Os franceses, Merleau-Ponty, por exemplo, falaram sobre o Leib. Meu colega Schipperges, um historiador da medicina de Heidelberg, denominou-o 'o corpo mundano vivido' [den gelebten welthaften Leib]. Ele deve ser aberto ao mundo, 'être au monde', como diz Merleau-Ponty, e vivo."167
\end{abstract}

Claramente o pensamento de Schmitz em relação à noção de corpo, bem como sua posição ao cientificismo, podem ser aproximados da obra de Merleau-Ponty, que desde os anos de 1940 já condenava a limitação da racionalidade à razão científica. Merleau-Ponty, assim

${ }^{166}$ Dias, Geraldo S. "O corpo em Mira - entrevista com Hermann Schmitz". op. cit.

167 Idem, ibidem. 
como fará Schmitz, não critica a ciência em geral. O filósofo francês, inclusive, identifica na própria ciência descobertas originais que the permitiram identificar o fundamento comum entre as dicotomias tradicionais. Por outro lado, ele irá criticar o subjetivismo filosófico, que constrói um sujeito universal descarnado, que pode tudo conhecer. Schmitz, fala da necessidade de nos distanciarmos da noção de corpo construída pela ciência e será justamente isso que permitirá a valorização da noção de Leib, e não a de Körper (corpo no sentido físico), para chegarmos ao corpo vivo e integral.

\footnotetext{
"Mas as pessoas pensam geralmente no corpo [Körper], e na verdade não podem dizer exatamente o que ele seja, a não ser que elas consigam se distanciar dos conceitos construídos pela ciência. O que seria deveras importante, senão elas estariam se referindo a esse substrato científico já pensado por Descartes, mas apenas enquanto máquina corporal. ${ }^{168}$
}

Por mais que ambos tenham se oposto ao idealismo cartesiano, obviamente a aproximação de Schmitz com Merleau-Ponty é parcial e superficial, até porque o filósofo francês jamais teve a pretensão de elaborar um sistema tal como Schmitz se propôs. E mesmo que ambos tenham sido leitores atentos de Husserl, não nos interessa aqui discutir até que ponto $o$ pensamento deles coincidem $e$ divergem, mas sim como podemos reencontrar no trabalho de Schendel algo da filosofia elaborada por eles.

Como é sabido, o artista não precisa ter o mesmo rigor que o filósofo tem com seu pensamento. $O$ artista tem a liberdade de se relacionar e se apropriar de elementos do pensamento filosófico conforme the convém, a partir de seu interesse e de sua própria poética. Schmitz reconheceu que apesar de Schendel estudar de modo disciplinado sua obra o diálogo entre eles não era fluido:

"[A Sra Schendel] destacava sempre motivos isolados de minha fenomenologia, principalmente o múltiplo caótico. A esse respeito conversamos muito, mas nunca surgiu ocasião para que pudéssemos situá-lo numa conexão mais abrangente. Eu não recrimino este fato, pois o artista pode

${ }^{168}$ Idem, ibidem. 
destacar motivos isolados sempre que precisar, para transformá-los em sua arte. O artista não deve envolver-se em algo assim, como um sistema. Isso não deve ser mal interpretado, pois creio que ela agiu corretamente, ao modo dela, mas, na realidade, não ocorria uma troca fluída de pensamentos." ${ }^{169}$

Para a Schendel, mesmo levando em conta que ela tenha citado publicamente a fenomenologia de Schmitz, interessava menos a totalidade de seu pensamento do que alguns motivos que ela identificava em seu trabalho. Não que um ilustrasse ou explicasse o outro, ou por qualquer relação de exterioridade entre pensamento e obra, mas como se a filosofia brotasse de dentro do seu trabalho, completamente integrada a ele. A noção de múltiplo caótico de Schmitz, que não tem relação com a desordem, mas que está ligada a uma série de noções da matemática, estava no entendimento livre de Schendel, ligada ao budismo, conforme ela anotou em seu caderno:

\footnotetext{
"Brahman é multiplicidade caótica em sentido transcendente e imanente. É multiplicidade individuada, é multiplicidade idêntica. Se filosoficamente, hoje, não se sustenta o nada, aí precisamos algo como o 'supra-ser'. O nome Brahman serve. Reste que não imitemos os hábitos da Índia. Ou não nos afiliemos a seitas de lá." ${ }^{\prime 10}$
}

Segundo Schmitz, multiplicidade caótica está ligada às impressões ambíguas que aparentemente possuem uma unidade interna, mas que são difusas e múltiplas. Na época em que conheceu Schendel, segundo o próprio Schmitz, tratava-se de um conceito relativamente isolado e que mais tarde foi interligado ao conceito de situação. Segundo o pensador alemão:

"[Multiplicidade caótica] é quando algo está, por assim dizer,
na ponta da língua, intuitivamente entendemos muito mais
do que podemos expressar. Eu desenvolvi a teoria do
múltiplo caótico principalmente no sentido de poder precisar
o que se entende por significação, uma expressão já

${ }^{169}$ Idem, ibidem.

${ }^{170}$ Schendel. Diário inédito. 
anteriormente empregada por Heidegger e por meu professor Rothacker, mas creio que o desenvolvimento posterior, ela [Schendel] não acompanhou. À época eu entendia o múltiplo caótico mais vinculado a uma continuidade ou algo semelhante. ${ }^{171}$

Schendel se interessou bastante pelo budismo, pelo I Ching, assim como pela noção de mutação, central na tradição do antigo oráculo chinês. Em seu diário de 1985, a artista escreveu: "O que dura são as mutações". Além das referências recorrentes ao budismo, em seu diário há também referências aos opostos Apolo e Dioniso, yin e yang, dentro e fora, feminino e masculino (que na se referem ao homem e a mulher necessariamente). "Nesse mundo, o caminho do meio não é cair nos opostos. ${ }^{172}$

Antes disso, em 1981, Schendel apresentou a série de têmperas chamada I Ching na XVI Bienal Internacional de São Paulo, em que dois campos de cor, aplicados em uma superfície lisa dividem o espaço vertical por uma espécie de linha do horizonte que surge do encontro dos tons distintos. A altura da linha varia de acordo com a quantidade de área de cada um dos tons, numa completa mutação em que uma cor espelha a outra. Dois trabalhos da série são monocromáticos e aboliram completamente qualquer alusão a uma linha do horizonte, bem como a alguma oposição entre "céu" e "terra" ou entre yin e yang, revelando um conjunto de seis obras, cada uma com a predominância de um tom.

No mesmo diário em que a artista traduziu fragmentos do texto de Schmitz sobre a tentativa de superação do dualismo, encontramos várias perguntas elaboradas para o oráculo chinês I Ching. As questões variam dos temas mais íntimos aos mais amplos e gerais, sobre alteridade, como por exemplo:

"Se apresenta de fato o problema da alteridade. Da individuação. Qualquer problema se torna estritamente meu.

\footnotetext{
${ }^{171}$ Dias, Geraldo S. "O corpo em Mira - entrevista com Hermann Schmitz". op. cit.

172 Schendel, Diário inédito, provavelmente escrito antes de 25 de agosto de 1985.
} 
Mas também intersubjetivo. As vezes me acontece que o problema dos outros me toquem. O que me diz o I Ching?"173

A artista também refletiu sobre o sentido e os motivos de recorrer ao oráculo, sobre a relação com o I Ching, a sabedoria, e as noções de liberdade e de necessidade que qualquer consulta ao oráculo pressupõe:

\begin{abstract}
"O I Ching me ajuda a vencer o medo de assumir desejos. 0 medo de ser humano. Acredito que a liberdade seja a da consciência. Que há os vícios das virtudes. Mas há o 'dever ser', ou o ser livre. Livre da condição humana. Como se não soubesse do lado obscuro da divindade. Como se não fosse dos poderes eu ser como sou. Afinal do que adianta a vida sem sabedoria? O saber sem sabedoria?"174
\end{abstract}

O vínculo que estabeleceu com a cultura oriental aparece em seu trabalho tanto na pesquisa sobre o vazio budista quanto em suas pinturas e desenhos com ouro. Nesse período, a artista realizou uma série de trabalhos em que aplicou folhas de ouro em superfícies limpas, predominantemente brancas, de diferentes tamanhos. Há nesses trabalhos um interesse pela arte chinesa despertado em grande parte nela pelo contato com o trabalho do pintor Chi Pai Schi.

As leituras que Schendel fez de Carl Gustav Jung (que pesquisou profundamente o I Ching) também a aproximaram da cultura e do pensamento oriental, assim como da noção de acaso. A série de Mandalas que pintou nos anos de 1974, exibidas no ano seguinte na Galeria de Mônica Filgueiras, são imagens arquetípicas que foram inspiradas em seus estudos sobre Jung, sobre as imagens do inconsciente e de sua busca pelo seu Selbst, o seu si mesmo.

O interesse de Schendel nesses temas envolve claramente uma tentativa de superação do dualismo a partir de duas forças complementares da tradição oriental o yin e o yang, o princípio ativo, luminoso e o princípio passivo, escuro, respectivamente. Nas Mandalas de Schendel há um claro equilíbrio que surge da sugestão

\footnotetext{
${ }^{173}$ Idem, ibidem.

${ }^{174}$ Idem, ibidem.
} 
de movimento, da mutação de uma força na outra. Cada Mandala é baseada nos princípios que teriam originado o próprio movimento do mundo e formam unidades fechadas em si mesmas. Em geral, Schendel pinta um grande círculo, dividido em quatro partes iguais, sobre um papel quadrado. Nele são circunscritos outros círculos, quadrados, elipses ou triângulos menores, sempre multiplicados por quatro. Algumas das Mandalas trazem pequenos detalhes em folhas de ouro, cores fortes e com acentuado contrastes. Elas representam a passagem entre estados psíquicos caóticos e ordenados, mas seriam antes de tudo a tentativa de união dos opostos tão perseguida em sua trajetória.

Em seu diário, Schendel faz uma comparação entre o processo de individuação tal como Jung elaborou, e a noção de multiplicidade caótica de Schmitz, para negar o dualismo cartesiano:

\begin{abstract}
"Qual a conclusão mais grave e séria a qual chego? Em termos de Jung que o Selbst é a matriz da consciência. Em termos de nova fenomenologia: situações são multiplicidade caótica. Multiplicidade caótica é por assim dizer o pano de fundo de qualquer individuação. A individuação é parcial. Não vejo aqui nenhum conflito intra-psíquico. Vejo que o mundo se individua, se decide para mim. Se o mundo fosse claro e distinto como desejava Cartesio [Descartes], não haveria situações." ${ }^{175}$
\end{abstract}

Apesar de seu interesse pela psicologia de Jung e pela teoria do processo de individuação, o que foi relevante para que a série de Mandalas fosse elaborada nos anos de 1974, alguns anos depois, em seu diário, Schendel se mostra reticente sobre as teorias de Jung e explicita que a fenomenologia e a noção de corporeidade acabaram tendo um peso maior em sua trajetória: "A interpretação de Jung é validada na doutrina de Jung. Mas prefiro 0 enfoque da fenomenologia da corporeidade. ${ }^{\prime 176}$

\footnotetext{
175 Idem, ibidem.

${ }^{176}$ Idem, ibidem.
} 


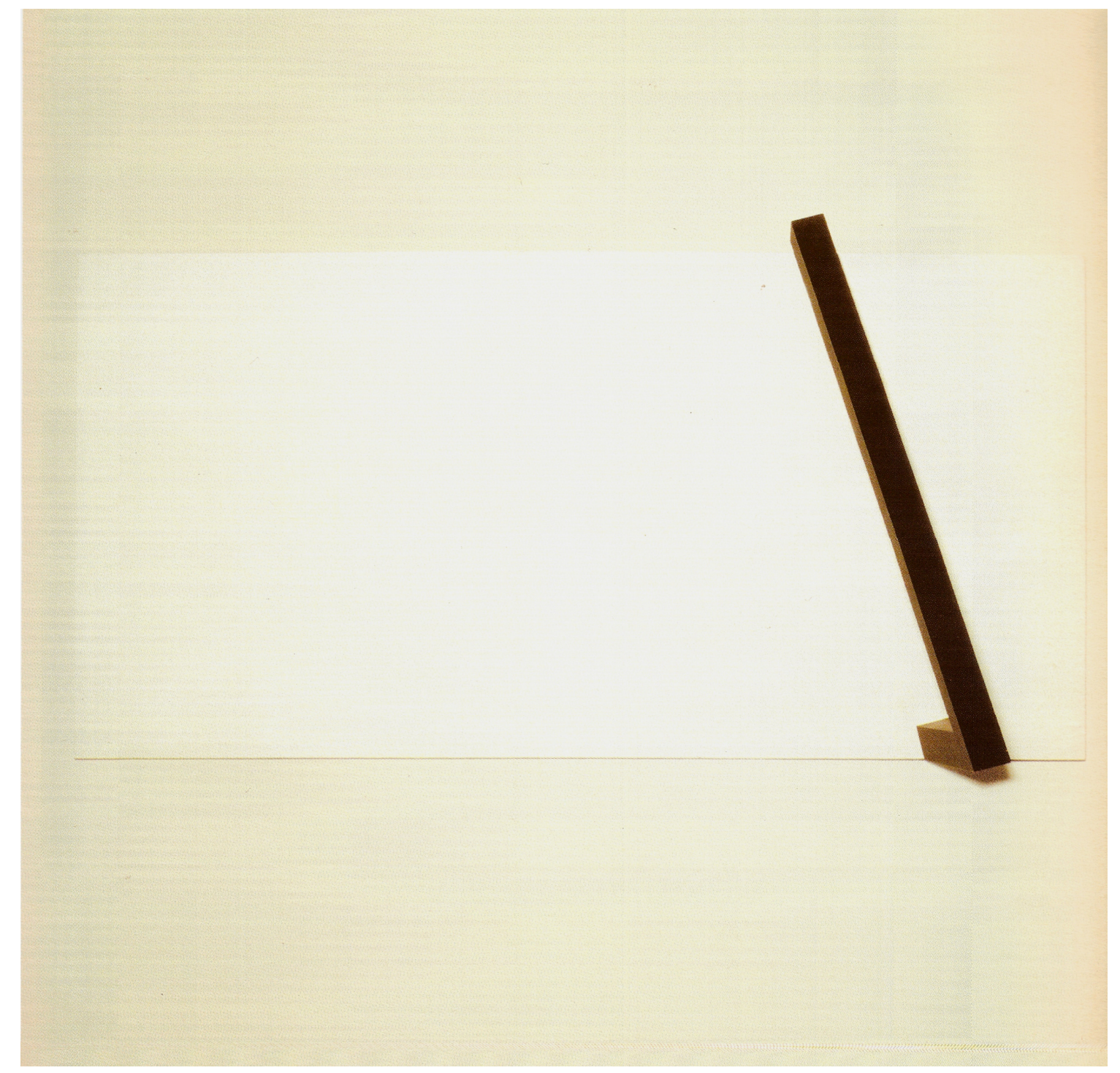

Sem Título (Sarrafo), 1987

Têmpera acrílica e gesso sobre madeira, 96x 180 × $45 \mathrm{~cm}$ 
"Aquele que acredita que a interpretação está restringida ou a deformar ou a retomar literalmente a significação de uma obra, na verdade, deseja que tal significação seja completamente positiva e suscetível, de direito, de um inventário capaz de delimitar o que está e o que não está nela. Quem acreditar nisso enganase sobre a obra e sobre o pensar"177.

Merleau-Ponty

\section{Conclusão}

A dimensão filosófica da obra de Mira Schendel surge primordialmente no interior de seu trabalho, como "filosofia selvagem", como pensamento original, elaborado em contato com o originário, o invisível, o silêncio e o impensado. Mesmo que ela se desdobre em diálogos com outros pensadores e que a artista manifeste seu interesse pela leitura de obras filosóficas, seu trabalho jamais poderia ser ilustração de algum pensamento.

Se não há intenção de Schendel em assumir alguma perspectiva filosófica é possível, no entanto, buscar aproximações entre seus trabalhos e diferentes formulações filosóficas. A noção de filosofia presente em seu trabalho surge: a) da indagação que a artista faz constantemente sobre si mesma, seu trabalho e o mundo; b) na relação que estabelece com alguns conceitos filosóficos como o de corporeidade; c) na rede de relações que estabelece com filósofos e pensadores como Vilen Flusser, Max Bense e Hermann Schmitz, além da leitura e discussão de diversos textos consagrados de Sartre, Wittgenstein, entre outros; d) da inseparabilidade entre arte e pensamento.

177 Merleau-Ponty, O filósofo e sua sombra. Textos Escolhidos. op. cit., p. 431. 
Não há exterioridade entre seu trabalho de arte e filosofia, talvez por isso sua obra tenha suscitado diálogos tão fecundos com intelectuais contemporâneos. A filosofia que habita a sua obra é uma filosofia bruta, envolvida num pensar e fazer livres. A artista se aproxima e se distancia de diferentes pensadores tendo apenas o compromisso com o próprio trabalho e não em ser fiel a algum autor ou escola de pensamento.

A metafísica que há em sua obra madura, não é a metafísica da transcendência, das substâncias puras, mas é a metafísica da imanência. Como vimos, Schendel lidou ao longo de toda a sua trajetória com a tentativa de superação da dicotomia entre essência e aparência, subjetivo e objetivo, ativo e passivo, corpo e alma. Ela reconheceu que embora não pudesse aniquilar o dualismo, ela poderia superá-lo, mesmo sabendo da dificuldade dessa ambição. Claro que essa superação não surge como um alívio, como um final positivo e bem sucedido de um percurso, mas atravessado por dúvidas, por indagações sobre o seu trabalho e o mundo, pelo sofrimento, pela dor, por avanços, recuos e pelas tensões próprias do pensamento.

Em determinados momentos de sua trajetória, a interrogação filosófica de Schendel se aproxima da teologia e da religião, seja do Antigo testamento, como vimos em Ondas paradas de probabilidade, seja de tradições orientais. Em 1975, ela realizou uma série de trabalhos com tinta spray e letras autocolantes sobre papel, no mesmo formato das monotipias, chamada Homenagem a Deus-Pai do Ocidente. Nela, passagens bíblicas e um gesto incisivo com tinta spray preta e marrom, convivem com a fala de um Deus poderoso, furioso, vingativo, que tem o poder de castigar e tudo destruir. A noção de Deus, palavra frequentemente escrita com letra minúscula em suas notas, não surge em seu trabalho como salvação ou bondade, mas inserida de modo difuso em seus amplos e dispersos interesses filosóficos. 
Embora muitos artistas modernos, tal como Mondrian ou Kandinsky, tenham aproximado seus trabalhos de noções espirituais e religiosas, Schendel se questiona em seus diários sobre seu interesse religioso, em especial no cristianismo ${ }^{178}$, discute a natureza do divino e questões da tradição oriental:

\begin{abstract}
"Por que você insiste tanto assim na teologia da Cruz? [...] Além de tudo não é moderno. E eu sou uma mulher 'tão moderna', como posso voltar sempre a isto? Por que não falo do que é concreto? Cotidiano? [...]

O divino não pode ser antropomorfizado. O divino aparece quando menos se espera. Não se prende na gaiola da teologia, do domingo, das igrejas e seitas. Se manifesta quando se manifesta. Imprevisivelmente. Não cabe a nós ditar regras. $[\ldots]$

Trinta anos atrás achava que por amor a deus tínhamos que ser ateus. [...] Tinha para mim ser o ateísmo contemporâneo (e a falta de confissão religiosa) purificador. Diria que se trata aqui de uma confissão preliminar. Estou ouvindo os pentecostais, aqui em baixo, cantando. Me considero - na linguagem tradicional - uma pessoa fundamentalmente religiosa. Minha experiência com o divino é - para mim irrecusável. E não sou espiritualista. [...]

Não combato o monoteísmo das pessoas monoteístas. Mas me oponho à tendência monoteísta onde a veja. Que haja este deus pra mim aqui e agora, admito. Acho óbvio. Pois sou pessoa. Apesar de não achar o divino pessoal, mas transpessoal. Mas que deva ser para todos e sempre acho delirante. ${ }^{\prime 179}$
\end{abstract}

A experiência com o divino, que vai se transformando profundamente durante sua vida, aparece dissociada das regras da igreja, de qualquer dogmatismo, porque tende a se aproximar da vida cotidiana, do mundo concreto e da realidade imanente. E mesmo que Schendel se entenda como uma pessoa religiosa, ela recusa o monoteísmo e o espiritualismo para se aproximar da filosofia, num sentido amplo, em busca da superação do dualismo.

\footnotetext{
${ }^{178}$ Schendel, nos anos de 1950, se interessou bastante pelo pensamento cristão de Emmanuel Mounier, em especial pelo livro O Personalismo. Por outro lado seus escritos também revelam interesse pela leitura de Pascal, Kierkegaard e Karl Jasper, entre outros filósofos.

${ }^{179}$ Schendel, diário inédito.
} 
Durante os anos de 1985, cerca de três anos antes de falecer, os diários de Schendel registram sua preocupação em encontrar um médico que trate do corpo como uma totalidade, um médico que trate do corpo e do espírito. Ao se referir a uma consulta médica escreveu: "O que é subjetivo para ele [médico] é psicológico. Da comunicação corpórea nada sabe.". E continua:

"A medicina dele não sabe ser senão psicossomática. Qualquer problema somático que não seja palpável é obviamente psíquico. A do psiquismo é uma gaveta onde se joga tudo o que não for de fato somático". ${ }^{180}$

Por outro lado, Schendel também critica a especialização e o desprezo pela subjetividade por parte de outros médicos, aqueles que temem qualquer envolvimento pessoal:

"Os especialistas podem perfeitamente acreditar na mais fria
objetividade. A subjetividade está ainda na gaveta do lixo
geral das ciências exatas: 'é só psicológico'. O modelo
preferido é o das ciências físicas, ainda, ora, qualquer
método é redutivo. Inclusive o fenomenológico: falamos clara
e abertamente de 'redução fenomenológica'. Ingenuidade
muito relativa". ${ }^{181}$

Essa passagem explicita a sua vontade de se afastar da visão de derivação cartesiana que tende a tratar o corpo ou como coisa, ou como consciência. Tradicionalmente, o corpo é corpo puro, uma soma de partes sem interior, e a alma uma presença evidente para si mesma, como se o sujeito fosse apenas aquilo que pensa ser, sem qualquer ambiguidade. Merleau-Ponty, na Fenomenologia da Percepção, elaborou uma noção de corpo diferente da tradicional:

"Portanto o corpo não é objeto. Pela mesma razão, a
consciência que tenho dele não é um pensamento, quer
dizer, não posso decompô-lo e recompô-lo para formar dele
uma ideia clara. Sua unidade é sempre implícita e confusa.
Ele é sempre outra coisa que aquilo que ele é, sempre
sexualidade ao mesmo tempo que liberdade, enraizado na
natureza no próprio momento em que se transforma pela

${ }^{180}$ Idem, ibidem.

${ }^{181}$ Idem, ibidem. 
cultura, nunca fechado em si mesmo e nunca ultrapassado. Quer se trate do corpo do outro ou do meu próprio corpo, não tenho outro meio de conhecer o corpo humano senão vivê-lo, quer dizer, retomar por minha conta o drama que o ultrapassa e confundir-me com ele. Portanto, sou meu corpo, exatamente na medida em que tenho um saber adquirido e, reciprocamente, meu corpo é como um sujeito natural, como um esboço provisório de meu ser total. ${ }^{182}$

A experiência que podemos ter com nosso corpo jamais seria com 0 conceito de corpo, ou com a cisão entre o objetivo do subjetivo. Porque o corpo não é pensamento de corpo, nem ideia, mas experiência corporal. Por isso Schendel em entrevista a Jorge Guinle Filho declarou:

\footnotetext{
"Mesmo a vida intelectual, vamos dizer, mesmo ela pressupõe uma disposição corpórea específica, ou seja, nunca nós podemos nos abstrair da corporeidade"183
}

A natureza corpórea do trabalho de Schendel se torna evidente nos papéis, em especial quando eles são retorcidos e amarrados, nas Droguinhas, ou simplesmente enfileirados e presos num fio, nos Trenzinhos, como se deixassem a atmosfera mais densa, evocando uma relação franca com o espaço fenomenológico e, portanto, completamente distante da representação desse espaço.

O gesto, como movimento e expressão, presentes nas monotipias, assim como o caráter processual das Droguinhas, já pressupõem, portanto, uma experiência corporal ou certa disposição corpórea. Por isso, podemos dizer que o trabalho de Schendel surge da expressão originária e primordial do corpo. E é do gesto corporal que nasce a caligrafia e a linguagem escrita.

Mas a linguagem, tal como Schendel a desenvolveu em sua trajetória, não é transparente, ao contrário, tanto é assim que a letra e o signo vão se tornando corpos opacos com acentuada presença física. A linguagem usada em seus trabalhos mais gráficos se

\footnotetext{
182 Merleau-Ponty, Fenomenologia da Percepção, op. cit. p. 269.

183 Schendel, "Mira Schendel, pintora", op. cit. p. 54.
} 
distancia da denotação ou da explicação. Trata-se de uma tentativa de penetrar nos sentidos, num mundo originário e anterior à própria linguagem, um mundo do sentido nascente, do excesso de sentidos. Daí a presença de palavras, de letras soltas, enigmáticas que retiram seu sentido da sua forma, da sua presença no espaço e da sua aparência gráfica.

Os trabalhos com letras adesivas prensadas em tocos de acrílicos são ao mesmo tempo transparentes e densos. É da noção de transparência, que nada tem a ver com a possibilidade de uma apreensão inequívoca do mundo, que surgem os Objetos Gráficos. O corpo do objeto, predominantemente transparente, é um corpo misterioso, inalcançável e ambíguo, para além da dicotomia sujeito/ objeto e interioridade/ exterioridade.

Existe também uma evidente dimensão corpórea em muitas de suas pinturas. Em vez de transparentes como os acrílicos e papéis, elas são espessas, densas e extrapolam qualquer rigidez geométrica. Schendel usou em muitas delas uma tinta grossa, com uma presença física contundente, às vezes misturada ao pó de tijolo ou a materiais orgânicos.

A última série completa de trabalhos que Schendel realizou foi a dos Sarrafos, cada um é construído a partir de uma grande placa de madeira pintada com têmpera acrílica branca de onde brota um sarrafo de $5 \mathrm{~cm}$ de cada lado. Um corpo sólido, tridimensional e negro, com ângulos agudos, na forma de um raio, se opõe ao fundo com um gesto tão incisivo, que parece desequilibrar todo o trabalho, de modo talvez mais severo que as linhas de spray de Homenagem a Deus-Pai do Ocidente. Segundo Ronaldo Brito, os Sarrafos ultrapassam definitivamente o dualismo clássico:

"Colocando e de pronto ultrapassando o problema, os Sarrafos de certo modo exemplificam o que jamais poderá se tornar exemplo e letra-morta: o salto a dimensão do corpóreo, para além dos pólos fixos de sujeito e objeto. Sobre tudo porque este salto não é apenas pura redução 
eidética - depende do curso da vida, da coragem e contingências, decisões e oportunidades". ${ }^{184}$

Mesmo que nesse período já não haja mais princípios da fenomenologia em seu trabalho, Schendel já estava desconfiada do método de redução fenomenológica, há aí uma evidente metafísica do corpo. E apesar da diferença de tom em relação à sutileza de muitas de suas obras anteriores, e de fato a artista declarou sua intenção de agressividade com os Sarrafos, essa série de trabalhos devido a sua dimensão corpórea se integra à sua produção sem marcar uma ruptura. Ela se diferencia dos trabalhos anteriores sem deixar de fazer parte da unidade de sua obra.

O percurso de Mira Schendel é heterogêneo, com obras aparentemente tão dispares que quase não existe uma ideia precisa de estilo, mas ao mesmo tempo há uma unidade ou então uma espécie de sistema de equivalências que geralmente nos permite identificar um trabalho seu. Em sua trajetória não existe guinada, grande ruptura ou mudança abrupta. Todo o seu processo de construção e invenção, que vai das pinturas do final dos anos de 1940 aos Sarrafos dos anos de 1980, revela uma incrível coesão, mesmo com as diferenciações que foram se processando ao longo dos anos.

Schendel possui um repertório mínimo, usando poucos materiais, e um vocabulário elementar de formas, sinais e letras, com ênfase na letra "a". O uso da primeira letra do abecedário, protagonista de uma série de desenhos, é revelador da postura de ir ao o início da sequencia alfabética, ao primeiro elemento da ordenação dos sinais gráficos.

Embora sua obra tenha predominantemente uma escala intimista, não é apenas da subjetividade, ou vida da artista que ela trata, antes de ser resultado ou consequência da biografia, a obra

${ }^{184}$ Brito, Ronaldo, "Singular e Plural". In: Salzstein, S. No Vazio do Mundo. op. cit. p. 274-275. 
exigiu a vida de Schendel para que fosse elaborada. Além disso, não se trata de um trabalho ensimesmado, mas de uma reflexão que se abre francamente para indagar o mundo. Há no trabalho de Schendel uma simplicidade e uma contundência, tudo isso num tom extremamente despretensioso e sóbrio. E mesmo que a dimensão filosófica de sua obra seja algo evidente - uma vez que a filosofia para a artista não é algo fora desse mundo, situada num céu metafísico, mas revela a estranheza fundamental desse mundo que habitamos - Schendel jamais poderia admitir qualquer qualidade excessivamente intelectual em seu trabalho ou pretensão de filiação ao conceitualismo. A filosofia no interior do trabalho de Schendel aparece na própria linguagem, mas se afasta da tradição da filosofia analítica para se aproximar da experiência direta com os materiais, com os outros, com a manualidade, com o corpo e com experiência cotidiana direta.

Face à noção de fim da história da arte, de quebra de uma história contínua e linear, a obra de Schendel pode ser compreendida como instituinte, como uma matriz que pede sequência temporal. A trajetória de Schendel, como a própria história, não é conduzida pela necessidade. Seu sentido é um sentido em devir, uma abertura. Em uma de suas monotipias ela escreve apenas a palavra "branco", como se do branco, do vazio e do silêncio pudesse surgir o fluxo permanente do pensamento e da arte, como se do fundo branco surgisse o próprio movimento ininterrupto do tempo.

Mesmo que não seja possível delimitar com precisão até que ponto elementos da filosofia de Merleau-Ponty estão ou não presentes na obra de Mira Schendel, uma vez que isso seria fixar positivamente o movimento do pensamento de sua obra, é inegável que Merleau-Ponty nos ajuda a compreender a dimensão filosófica de seu trabalho, assim como, seu trabalho também ilumina o pensamento do filósofo francês. Mira Schendel ilumina a filosofia de Merleau-Ponty e vice-versa, na medida em que ele nos ajuda a 
mostrar que ela elabora uma espécie de filosofia da visão. Há uma dimensão universal na obra de Merleau-Ponty que permite que sua obra seja vista à luz de muitos trabalhos de arte realizados ao longo da história, sem que isso nos separe das questões centrais da filosofia ou do trabalho dos artistas. Não no sentido de determinada obra de arte provar alguma verdade filosófica, mas porque MerleauPonty está entre os filósofos que mais se aproximou do processo criativo e percebeu como ninguém que na experiência artística, e na própria noção de expressão, há uma filosofia bruta. Como ele formula: "filosofia e arte, juntas, não são fabricações arbitrárias no universo da cultura, mas contato com o Ser justamente enquanto criações" ${ }^{185}$

A dimensão filosófica do trabalho de Schendel não está na autoconsciência filosófica da arte, está no quiasma, no entrecruzamento da necessidade e da contingência. Se o pensamento necessariamente é rompimento do silêncio, o pensamento bruto da obra de Mira Schendel está entre o dizível e o indizível, e na reversibilidade do visível e do invisível.

${ }^{185}$ Merleau-Ponty. O visível e o invisível. op. cit. p. 187. 


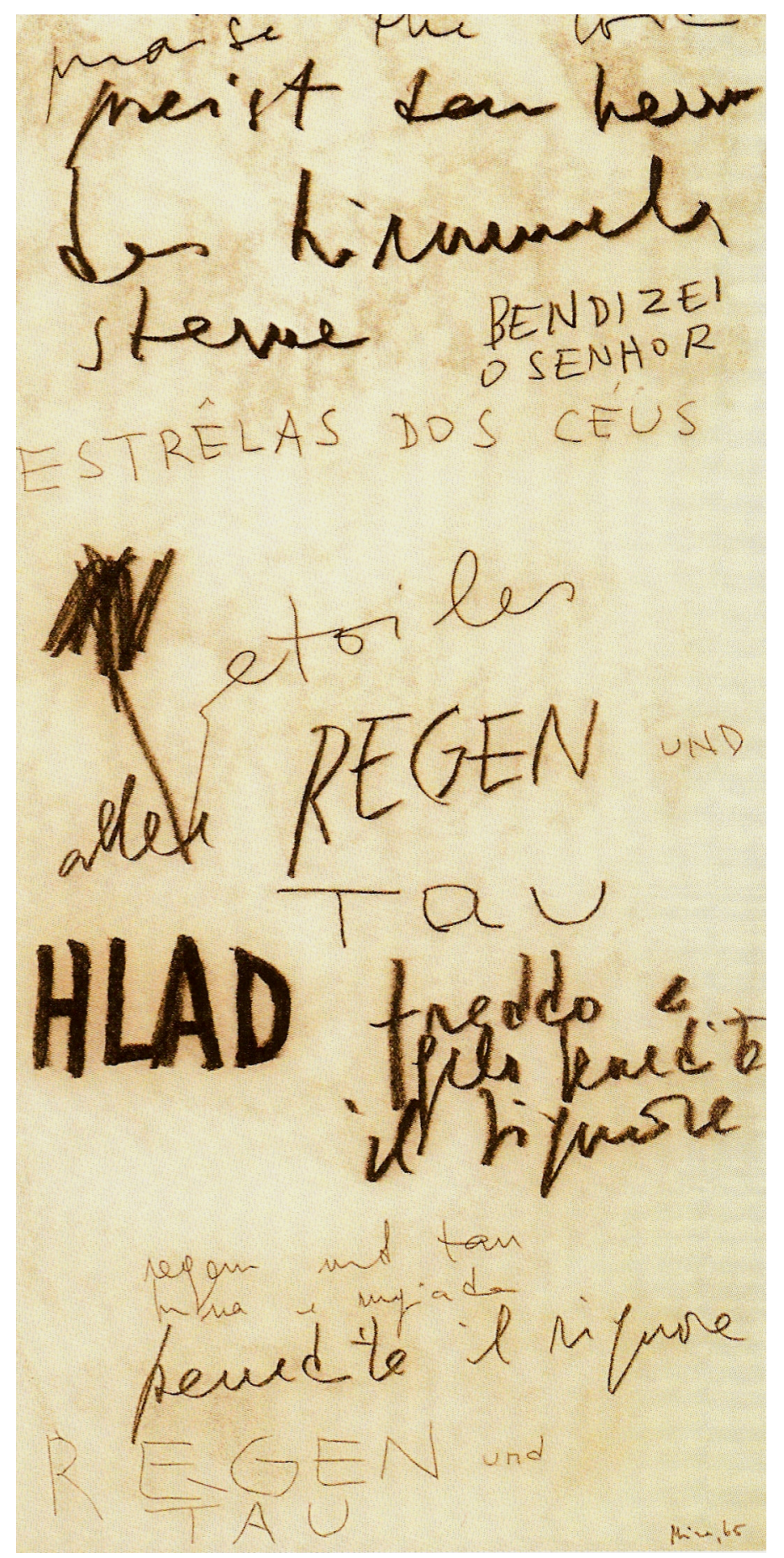

Sem Título, 1965

Transferência de Óleo sobre papel, 45 × 22,7 cm 


\section{Bibliografia}

\section{1) Fontes Primárias}

HEGEL, G. W. F. Cursos de Estética (trad. Marco Aurélio Werle). São Paulo: Edusp, 2001.

HEIDEGGER, Martin. A origem da Obra de Arte. (trad. Maria da

Conceição Costa). Lisboa: Edições 70, 2008.

MERLEAU-PONTY, M. A Estrutura do Comportamento. Trad. Márcia

Valéria Martinez de Aguiar. São Paulo: Martins Fontes, 2006.

----------. Fenomenologia da Percepção. Trad. de C. A. Ribeiro de Moura. São Paulo: Martins Fontes, 1996.

---------. Elogio da Filosofia. Trad. de António Braz Teixeira. Lisboa: Guimarães Editores, 1993.

O Primado da Percepção e suas Conseqüências Filosóficas.

Trad. de C. Marcondes Cesar. Campinas: Papirus, 1990.

. Merleau-Ponty na Sorbonne: resumo de cursos (1949-

1952). Trad. de C. Marcondes Cesar. Campinas: Papirus, 1990.

--------. Textos Escolhidos. Trad. de M. S. Chauí; N. Aguilar; P. S.

Moraes; G. D. Barreto. São Paulo: Abril Cultural, 1975.

(Coleção Os Pensadores).

--------. Signos. Trad. de M. E.G. Gomes Pereira. São Paulo: Martins Fontes, 1991.

. A natureza. Trad. de Álvaro Cabral. São Paulo: Martins Fontes, 2006.

--------. Conversas - 1948. Trad. de Fábio Landa e Eva Landa. São Paulo: Martins Fontes, 2004.

---------. O Visível e o Invisível. Trad. J. A. Giannotti, A. M. d'Oliveira. São Paulo: Perspectiva, 2000.

. A Prosa do Mundo. Trad. Paulo Neves. São Paulo: Cosac \& Naify, 2002.

---------. O olho e o espírito. São Paulo: Cosac \& Naify, 2004. 
As Aventuras da Dialética. São Paulo: Martins Fontes, 2006.

-. L'institution, in: Resume de Cours, Collège de France 1952-

1960. Paris: Galimard, 1968.

NIETZSCHE, F. Escritos sobre história. Rio de Janeiro: Ed. PUC - Rio;

São Paulo: Loyola, 2005.

SARTRE, J-P. Entre quatro paredes. São Paulo: Civilização Brasileira, 2007.

O Ser e o Nada - ensaio de ontologia fenomenológica.

Petrópolis, RJ: Vozes, 1997.

WITTGENSTEIN, Ludwig. Tractatus Logico-Philosophicus (trad. Luiz Henrique Lopes dos Santos). São Paulo: Edusp, 2008.

\section{2) Textos de e sobre Mira Schendel}

Arquivo Mira Schendel com cadernos, textos, cartas, diários, entrevistas e anotações da artista além de textos sobre ela e recortes de jornal. Coleção Adda Schendel.

AMARAL, Aracy. "Mira Schendel: os cadernos". Arte e meio artístico: entre a feijoada e o x-burguer. São Paulo: Nobel, 1983.

BENSE, Max. "Mira Schendel: reduções gráficas". Pequena Estética. São Paulo: Editora Perspectiva, 1971.

BRETT, Guy. "Shendel", Kineyic art: the language of movement. Londres: Studio Vista, 1968.

BRITO. Ronaldo. "O flúido dos sólidos". Experiência Crítica. São Paulo: Cosac Naify, 2005.

--------. "Singular no Plural" ". Experiência Crítica. São Paulo: Cosac Naify, 2005.

DIAS, Geraldo Souza. "Contundência e delicadeza na obra de Mira Shendel" Ars. Revista do Dep. De Artes Plásticas da ECA-USP. São Paulo: ECA-USP, no 1, 2003. 
--------. Mira Schendel: do espiritual à corporeidade. São Paulo: Cosa Naify, 2009.

--------. "O corpo em Mira: entrevista com Hermann Schmitz". Novos Estudos CEBRAP, São Paulo: n. 74, 2006.

FLUSSER, Vilen. "Indagações sobre a origem da língua". O Estado de São Paulo, São Paulo: 29 de abril de 1967.

--------. "Mira Schendel", Arte em São Paulo. São Paulo: n. 36, 1987.

------. "Fora do alcance da língua" Arte em São Paulo. São Paulo:

n. 36, 1987.

GUINLE FILHO, "Mira Schendel, pintora: o espaço vazio me comove profundamente", Interview, São Paulo, jul. 1981.

HERKENHOFF, Paulo. "Mira Schendel e a configuração do inexpressável". Mira Schendel Monotipias. São Paulo e Londres: Galeria Millan/ Stephen Friedman Gallery, 2009. KUDIELKA, Robert. "According to what: art and the philosophy of the 'end of art'." Theme Issue 37. Danto and His Critics: Art History, historiography and After the End of Art. Middletown, Connecticut: Wesleyan University, 1998.

KAUTZ, Willy. Mira Schendel: continuum amorfo. México: Fundación Olga y Rufino Tamayo: Museu de Arte Contemporâneo de Monterrey, 2004.

LAGNADO, Lisette. Transparência e Escritura nas Monotipias de Mira Schendel. Dissertação de mestrado. São Paulo: PUC-SP, 1997. MAMMÍ. Lorenzo. "Duas galerias fazem retrospectiva de Mira Schendel". Folha de São Paulo, São Paulo: 7 de março de 1989. MARQUES, Maria Eduarda. Mira Schendel. São Paulo: Cosas \& Naify, 2001.

NAVES, Rodrigo. "Mira Schendel: pelas costas". O vento e o moinho: ensaios sobre arte moderna e contemporânea. São Paulo: Companhia das Letras, 2007. 
---------. "Mira Schendel: o presente como utopia". O vento e o moinho: ensaios sobre arte moderna e contemporânea. São Paulo: Companhia das Letras, 2007.

---------. "Mira Schendel, o mundo como generosidade". OESP, 29 de Março de 2009.

PEDROSA, Mário; "Mira Schendel". Acadêmicos e Modernos. Textos Escolhidos III. Org. de Otília Arantes. São Paulo: Edusp, 1998. PÉREZ-ORAMAS, Luis. Léon Ferrari and Mira Schendel tangled alphabets. New York e São Paulo: Museum of Modern Art/ Cosac Naify, 2009.

"O Alfabeto enfurecido: post-scriptum". O Alfabeto enfurecido: Léon Ferrari e Mira Schendel. Porto Alegre: Fundação Iberê Camargo, 2010.

SALZSTEIN, Sônia. No vazio do mundo. São Paulo: Fiesp/ Marca D’Água, 1996.

----------. "Resistindo ao presente: a arte de Mira Schendel". Novos Estudos CEBRAP, São Paulo, n. 43, Nov. 1995.

--------. "À espreita, na superfície da linguagem". Ars. Revista do Dep. De Artes Plásticas da ECA-USP, no 9. São Paulo: ECA-USP, 2007.

--------. "A forma volátil: Mira Schendel". Rio de Janeiro: Centro de Arte Hélio Oiticica, 1993.

SCHENBERG, Mário. "Mira Schendel". São Paulo: Galeria Astréia, 1964.

VENÂNCIO FILHO, Paulo. "Hipótese sobre um trabalho de Mira Shendel". No vazio do mundo. São Paulo: Fiesp/ Marca D'Água, 1996. 


\section{3) Bibliografia Geral e Arte Brasileira}

ADES, Dawn (et alli). Arte na América Latina: a era moderna. Trad. de M. T. de Rezende Costa. São Paulo: Cosac \& Naify, 1997.

AITA. Virgínia. "Arthur Danto: Negatividade e história da arte sub specie aeternitatis ou a arte sob o olhar do filosofo" Ars. Revista do Dep. De Artes Plásticas da ECA-USP, no 1. São Paulo: ECAUSP, 2003.

AMARAL, Aracy (coord.). Projeto Construtivo na Arte: 1950-1962. Rio de Janeiro/ São Paulo: Museu de Arte Moderna do Rio de Janeiro e Pinacoteca do Estado de São Paulo, 1977.

-------. (org.). Arte Construtiva no Brasil. Coleção Adolpho Leirner. São Paulo: DBA/ Melhoramentos, 1998.

---------. Arte para quê? A preocupação Social na Arte Brasileira (1930-1970). São Paulo: Nobel, 1984.

ARANTES, Otília B. F. Mario Pedrosa: intinerário crítico. São Paulo: Scritta, 1991.

ARANTES, Paulo Eduardo. Hegel: a ordem do tempo. São Paulo: Hucitec/ Polis, 2000.

ARGAN, Giulio Carlo. Arte Moderna. Trad. Denise Bottmann e Federico Carotti. São Paulo: Companhia das Letras, 1992.

---------. Arte e Crítica de Arte. Trad. Helena Gubernatis. Lisboa: Editorial Estampa, 1988.

ARNHEIM, Rudolf. Arte e Percepção Visual: Uma psicologia da visão criadora. Trad. de Ivonne T. de Faria. São Paulo: Livraria Pioneira/ EDUSP, 1980.

AYALA, Walmir. A Criação Plástica em Questão. Petrópolis, RJ: Vozes. 1970.

BELTING, Hans. O fim da história da arte: uma revisão dez anos depois. São Paulo: Cosa Naify, 2006. 
BONAN, Ronald. Premières leçons sur l'esthétique de Merleau-Ponty. Paris, P.U.F., 1997.

BARBARAS, Renaud. "Sentir e Fazer: a fenomenologia e a unidade da estética". Novos Estudos, n 54. São Paulo: CEBRAP, julho de 1999.

BELLUZZO, Ana Maria de Morais (org.) Modernidade: vanguardas artísticas na América Latina. São Paulo: Memorial/UNESP, 1990.

BIMBENET, Étienne. Nature et Humanité: Le problème anthropologique dans I'oevre de Merleau-Ponty. Paris: Librairie Philosophique J. Vrin, 2004.

BOSI, Alfredo. "Fenomenologia do Olhar". in: Novaes, A. (org.). O Olhar. São Paulo: Cia. das Letras, 1989.

BRETT, G. Brasil Experimental arte / vida: proposições e paradoxos. Rio de Janeiro: Contra Capa, 2005.

BRIONY, Fer (et alii). Realismo, Racionalismo, Surrealismo. São Paulo: Cosac \& Naify, 1998.

BRITO, Ronaldo. Neoconcretismo, Vértice e Ruptura do Projeto Construtivo Brasileiro. São Paulo: Cosac \& Naify, 1999.

BÜRGER, Peter. "O Declíneo da Era Moderna". Trad. de Heloísa Jahn. Novos Estudos, n²0. São Paulo: CEBRAP, março de 1988.

--------. Teoria da vanguarda. Trad. Ernesto Sampaio. Lisboa: Vega, 1993.

CÂMARA, José Bettencourt. Expressão e Contemporaneidade: a arte moderna segundo Merleau-Ponty. Lisboa: Imprensa NacionalCasa da Moeda, 2005.

CAMPOS, Augusto de; PIGNATARI, Décio; CAMPOS, Haroldo de. Teoria da poesia concreta. Cotia, SP: Ateliê Editorial, 2006. CANDIDO, Antonio. "Literatura e subdesenvolvimento", in A Educação pela Noite. São Paulo: Ática, 1987. 
CHAUÍ, Marilena. Merleau-Ponty e a Crítica ao Humanismo. Tese de Mestrado. São Paulo: FFLCH-USP, 1967.

---------. Da Realidade sem Mistérios ao Mistério do Mundo. São Paulo: Brasiliense, 1981.

. Conformismo e Resistência. Aspectos da cultura popular no Brasil. São Paulo: Brasiliense, 1986.

----------. Brasil. Mito Fundador e sociedade autoritária. São Paulo: Fundação Perseu Abramo, 2000.

---------. Experiência do Pensamento. São Paulo: Martins Fontes, 2002.

CHIPP, H. B. (org.). Teorias da Arte Moderna. São Paulo: Martins Fontes, 1988.

COCCHIARALE, Fernando \& GEIGER, Anna Bella (org.). Abstracionismo geométrico e informal. A vanguarda brasileira nos anos cinqüenta. Rio de Janeiro: FUNARTE/ Inap, 1987.

COELHO JR., Nelson \& Carmo, Paulo Sérgio do. Merleau-Ponty: filosofia como corpo e existência. São Paulo: Escuta, 1991.

DANTO, A. Após o fim da arte: A arte contemporânea e os limites da história. São Paulo: Odysseus Editora, 2006.

---------. As ideias de Sartre. São Paulo: Cultrix, 1975

--------. A transfiguração do lugar-comum. São Paulo: Cosac Naify, 2005.

-------. "O filósofo como Andy Warhol". Ars, ano 2 n. 4, 2004

DICKIE, G. Art and the Aesthetics: An Institutional Analysis. Ithaca, NY: Cornell University Press, 1974.

FERRAZ, Marcus Sacrini A. Fenomenologia e ontologia em MerleauPonty. Campinas, SP: Papirus. 2009.

FERREIRA, G. e COTRIM, Cecília. (org.) Escritos de artistas: anos 60 e 70. Rio de Janeiro: Jorge Zahar Ed., 2006.

--------. (Org.) Clement Greenberg e o debate crítico. Rio de Janeiro: Funarte e Jorge Zahar, 1997. 
FERREIRA, G. Crítica de Arte no Brasil: temáticas Contemporâneas. Rio de Janeiro: Funarte, 2006.

FLUSSER, Vilém. A escrita - Há futuro para a escrita?. São Paulo:

Annablume, 2010.

- Bodenlos - Uma autobiografia filosófica. São Paulo:

Annablume, 2007.

--------. Língua e Realidade. São Paulo: Annablume, 2007.

-. O Universo das imagens técnicas. São Paulo: Annablume, 2008.

FRANCASTEL, Pierre. Pintura e Sociedade. Trad. de Élcio Fernandes. São Paulo: Martins Fontes, 1990.

FREIRE, Cristina. Arte conceitual. Rio de Janeiro: Jorge Zahar Ed., 2006.

GELL, Alfred. "A rede de Vogel: armadilhas como obras de arte e obras de arte como armadilhas". Revista do Programa de PósGraduação em Artes Visuais EBA - UFRJ, 2001.

GIANNOTTI, J. A. O jogo do belo e do feio. São Paulo: Cia das Letras, 2005.

GULLAR, F. Argumentação contra a morte da arte. Rio de Janeiro: Revan, 2005.

--------. "Arte Neoconcreta uma Contribuição Brasileira". Crítica de Arte, $n^{\circ} 1$, Rio de Janeiro, 1961. (Publicação da A.B.C.A.).

---------. Etapas da Arte Contemporânea: do cubismo à arte neoconcreta. Rio de Janeiro, Revan, 1999.

--------. "Manifesto Neoconcreto", in: Amaral. Aracy. (coord.). Projeto Construtivo na Arte: 1950-1962. Rio de Janeiro/ São Paulo: Museu de Arte Moderna do Rio de Janeiro e Pinacoteca do Estado de São Paulo, 1977.

-------. "Teoria do Não-Objeto", in: Amaral. Aracy. (coord.). Projeto Construtivo na Arte: 1950-1962. Rio de Janeiro/ São Paulo: Museu de Arte Moderna do Rio de Janeiro e Pinacoteca do Estado de São Paulo, 1977. 
---------. Vanguarda e Subdesenvolvimento. Rio de Janeiro: Editora Civilização Brasileira, 1969.

HARVEY, David. Condição Pós-moderna. São Paulo: Edições Loyola, 2008.

HOLANDA, Sergio Buarque de. Raízes do Brasil. Rio de Janeiro: José Olympio, 1986.

JAMESON, Frederic. A lógica cultural do capitalismo tardio. São Paulo: Ática, 2007.

---------. A Cultura do dinheiro: ensaios sobre a globalização. Petrópolis, RJ: Vozes: 2002.

KLEIN, Robert. A Forma inteligível. São Paulo: EDUSP, 1998.

KOSUTH, Joseph. "Arte depois da filosofia", in: Malasartes, Rio de Janeiro: no. 1, 1975.

LIPPARD, Lucy. Six Years: The Dematerialization of the Art Object from 1962 to 1972. New York: Praeger, 1973.

LYOTARD, Jean-François. A Condição Pós-Moderna. Rio de Janeiro: José Olympio, 2008.

------. A Fenomenologia. Lisboa: Edições 70, 1999.

MAMMİ, Lorenzo. "Mortes recentes da arte". Novos Estudos, n० 60. São Paulo: CEBRAP, Julho de 2001.

MOURA, Carlos Alberto Ribeiro. Racionalidade em Crise. Tese de Livre Docência, São Paulo: FFLCH-USP, 2000.

MOUTINHO, Luiz Damon Santos. Razão e experiência: ensaios sobre Merleau-Ponty. São Paulo: Editora UNESP, 2006.

NAVES, Rodrigo. A forma difícil: ensaios sobre arte brasileira. São Paulo: Ática, 1997.

PEDROSA, Mário. Mundo, homem, arte em crise. Org. de Aracy Amaral. São Paulo: Perspectiva, 1975.

--------. Política das Artes. Textos Escolhidos I. Org. de Otília Arantes. São Paulo: Edusp, 1995.

---------. Forma e Percepção Estética. Textos Escolhidos II. Org. de Otília Arantes. São Paulo: Edusp, 1996. 
---------. Modernidade Cá e Lá. Textos Escolhidos IV. Org. de Otília Arantes. São Paulo: Edusp, 2000.

PRADO JR, Caio. Formação do Brasil Contemporâneo. São Paulo: Brasiliense, 1994.

PRADO JR, Bento. Presença e Campo Transcendental: consciência e negatividade na filosofia de Bergson. São Paulo: EDUSP, 1989.

READ, Hebert. História da Pintura Moderna. Rio de Janeiro: Zahar, 1980.

SALZSTEIN. Sônia. A questão Moderna/ Impasses e Perspectivas na Arte Brasileira, 1910 a 1950. Tese de doutoramento. São Paulo: Dep. de Filosofia, FFLCH-USP, 2000.

--------. Arte, Instituição e Modernização Cultural no Brasil: uma experiência institucional. Dissertação de Mestrado. São Paulo: Dep. de Filosofia, FFLCH-USP, 1994.

--------.."Transformações na esfera da crítica". Ars. Revista do dep. de Artes Plásticas da ECA-USP. São Paulo: ECA-USP, no 1, 2003.

SCHWARZ. Roberto. Que horas são? Ensaios. São Paulo: Cia. das Letras, 1987.

---------. Seqüências Brasileiras: ensaios. São Paulo: Cia. Das Letras, 1999.

-------. "Cultura e Política, 1964-69". In: O Pai de Família e outros estudos. Rio de Janeiro: Paz e Terra, 1978.

SILVA, Franklin Leopoldo e. Bergson: intuição e Discurso filosófico. São Paulo: Edições Loyola, c. 1994.

TASSINARI, Alberto. O Espaço Moderno. São Paulo: Cosac \& Naify, 2001.

VATTIMO, Gianni. O Fim da Modernidade: niilismo e hermenêutica na cultura pós-moderna. São Paulo: Martins Fontes, 2007.

WÖLFFLIN, Heinrich. Conceitos fundamentais da história da arte: o problema da evolução dos estilos na arte mais recente. São Paulo: Martins Fontes, 2000. 
WOOD, Paul (et alii). Modernismo em disputa. São Paulo: Cosac \& Naify, 1998.

--------. Arte Conceitual. São Paulo: Cosac \& Naify, 2002.

ZANINI, Walter (coord.) História Geral da Arte no Brasil. São Paulo: Instituto Moreira Salles/ Fundação Djalma Marinho, 1983, vol. II.

ZÍLIO, Carlos. "Da Antropofagia à Tropicália". In: O Nacional e o Popular na Cultura Brasileira - Artes Plásticas e Literatura. São Paulo: Brasiliense, 1982. 
Reproduções de trabalhos de Mira Schendel 


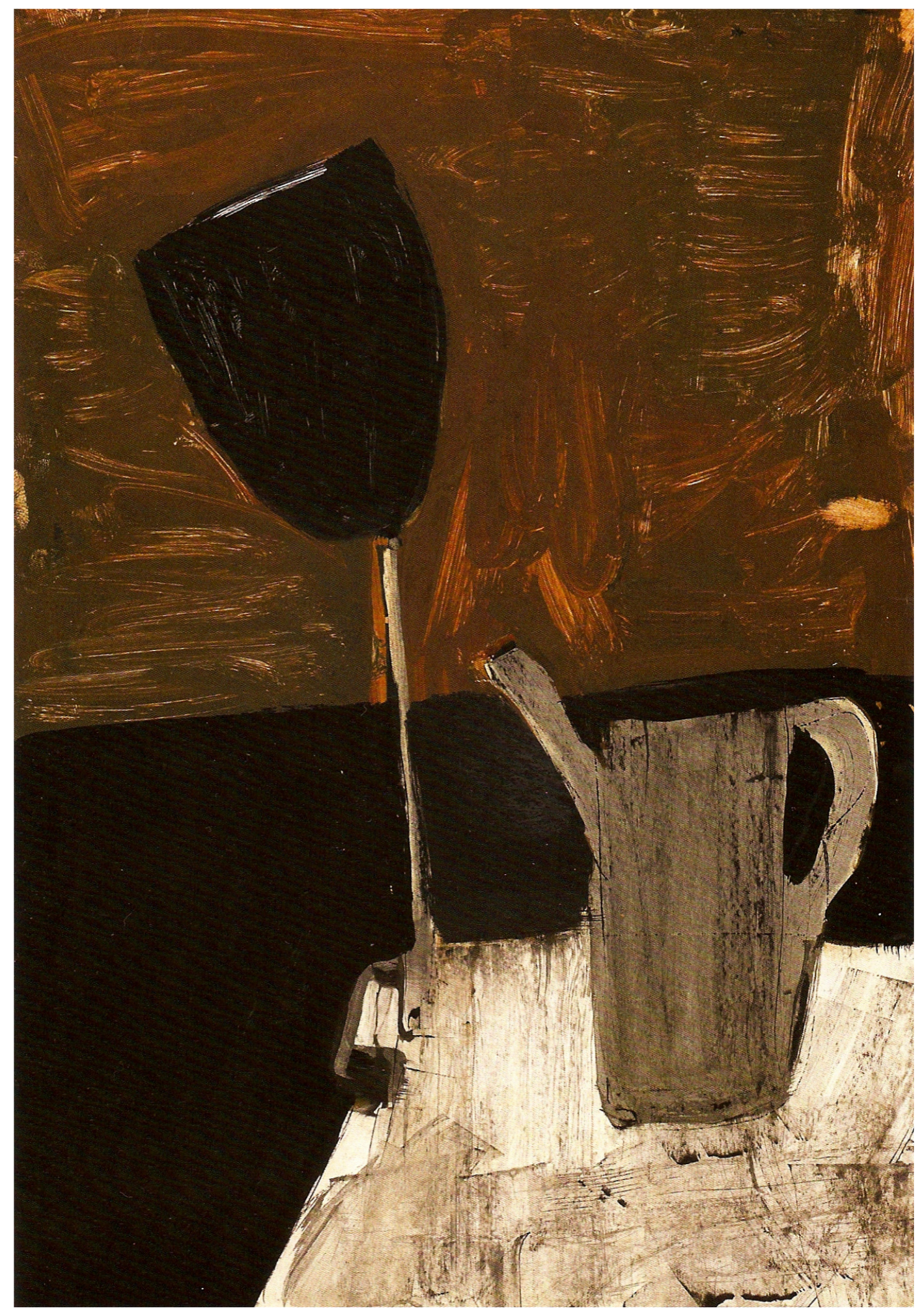

Sem Título, 1951

Têmpera sobre papel, $32,5 \times 22,5 \mathrm{~cm}$ 


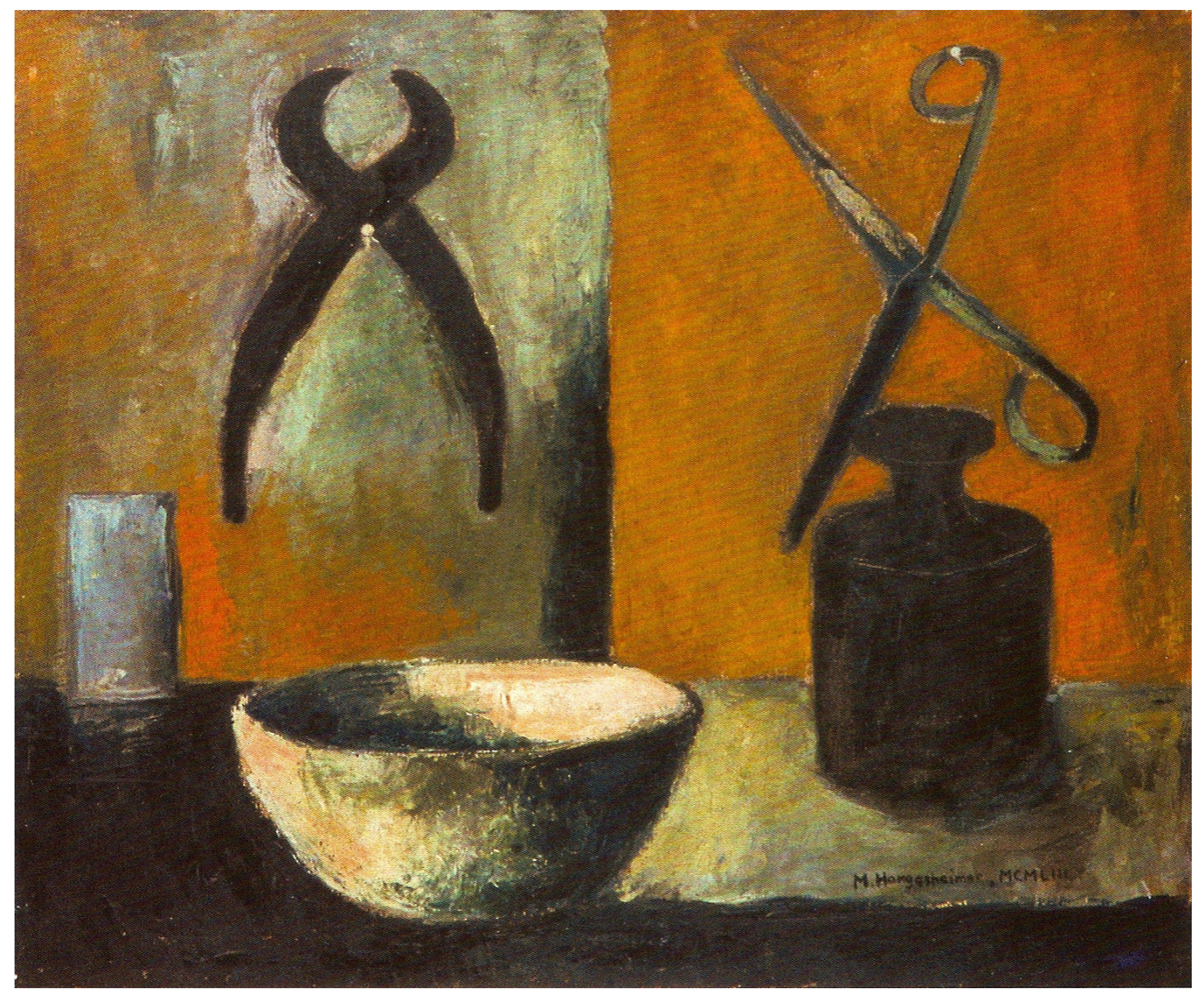

Sem Título, 1953

Óleo sobre tela, $50 \times 60,2 \mathrm{~cm}$

Col. Museu de Arte Contemporânea da Universidade de São Paulo, São Paulo 


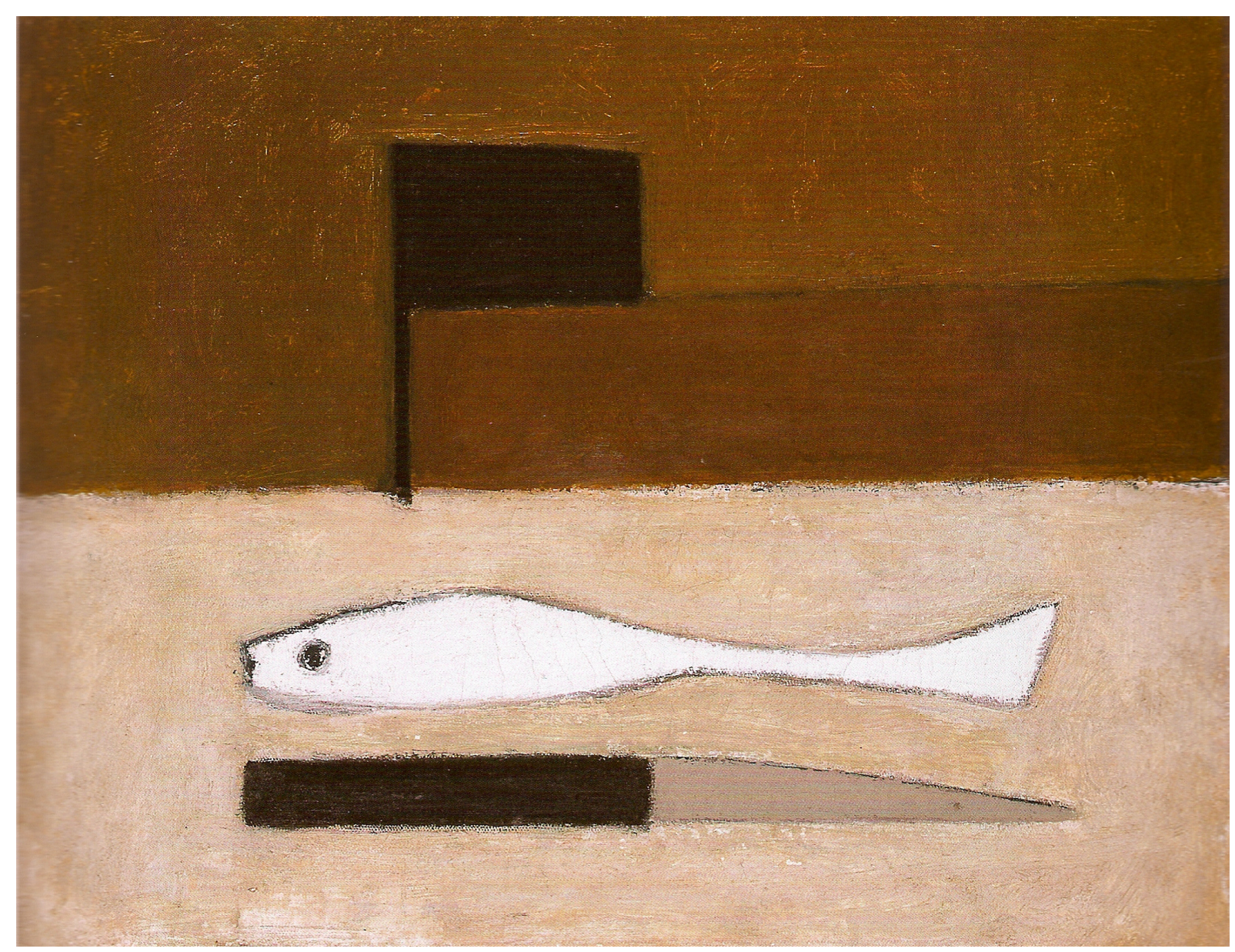

Sem Título, 1953

Óleo sobre tela, 27 × $35 \mathrm{~cm}$ 


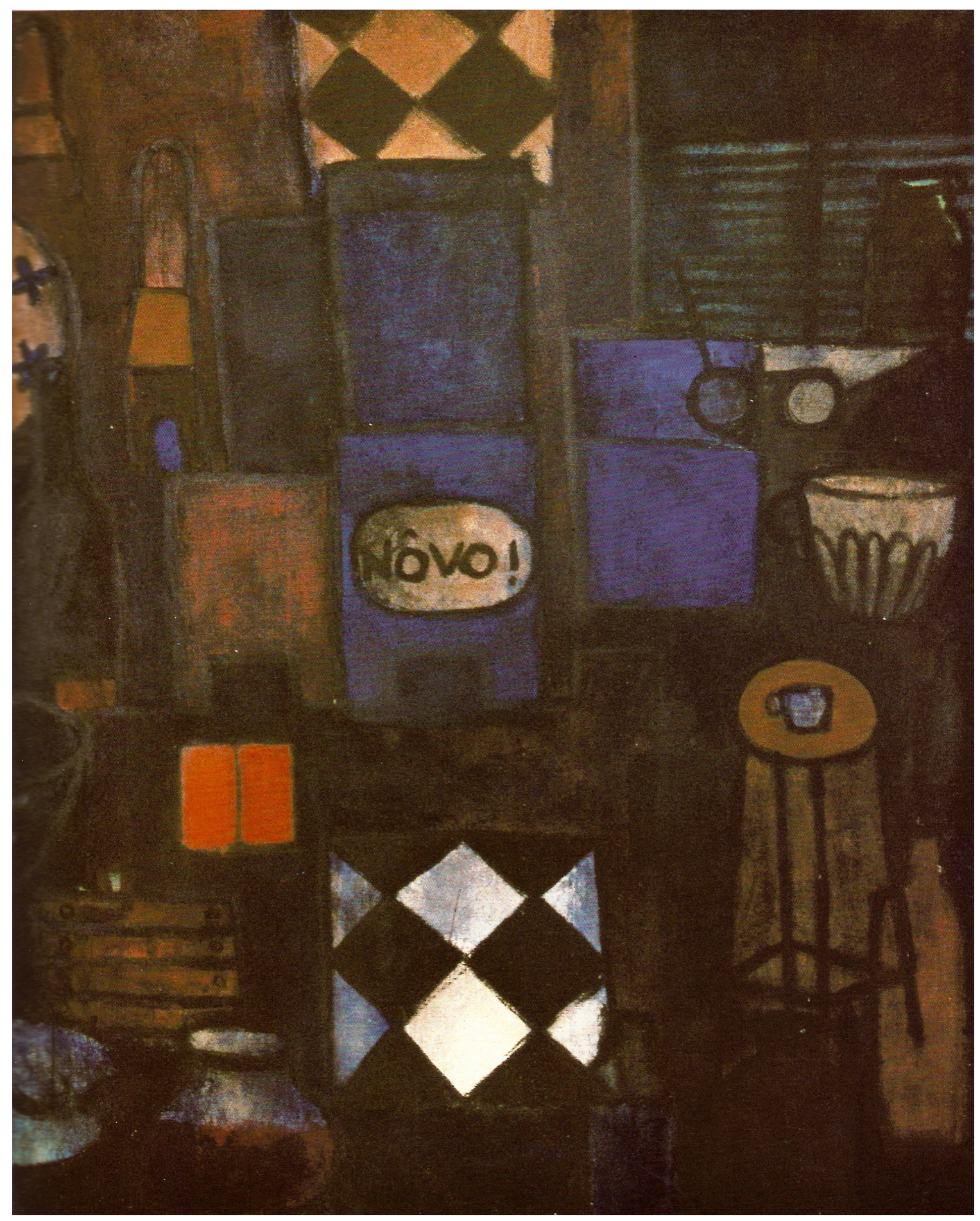

Sem Título (novo), sem data

Óleo sobre tela, $146 \times 114 \mathrm{~cm}$ 


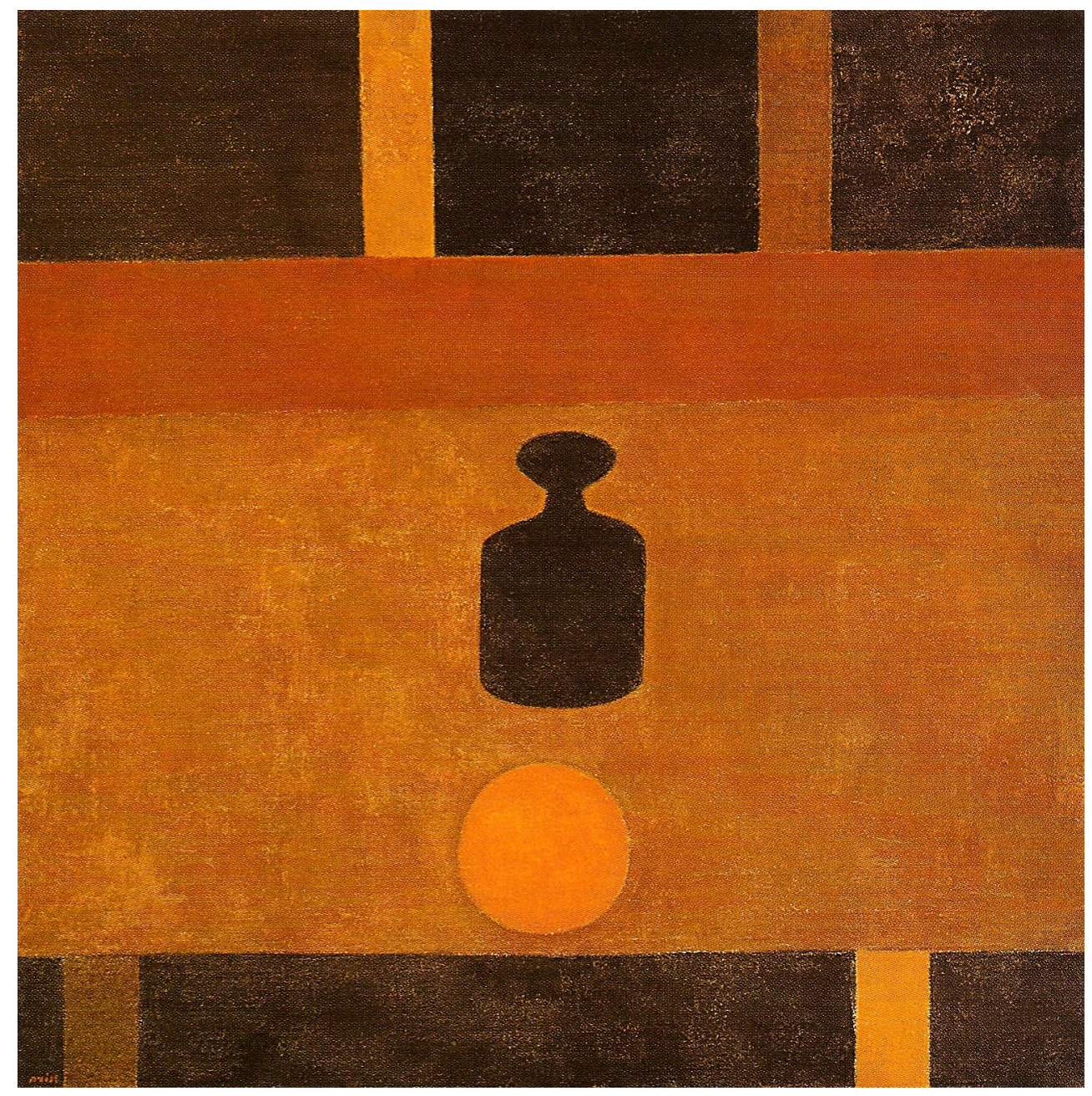

Sem Título, dec. 1960

Óleo sobre tela, $74,6 \times 74,6 \mathrm{~cm}$

Col. Museu de Arte Contemporânea Universidade de São Paulo, São Paulo 


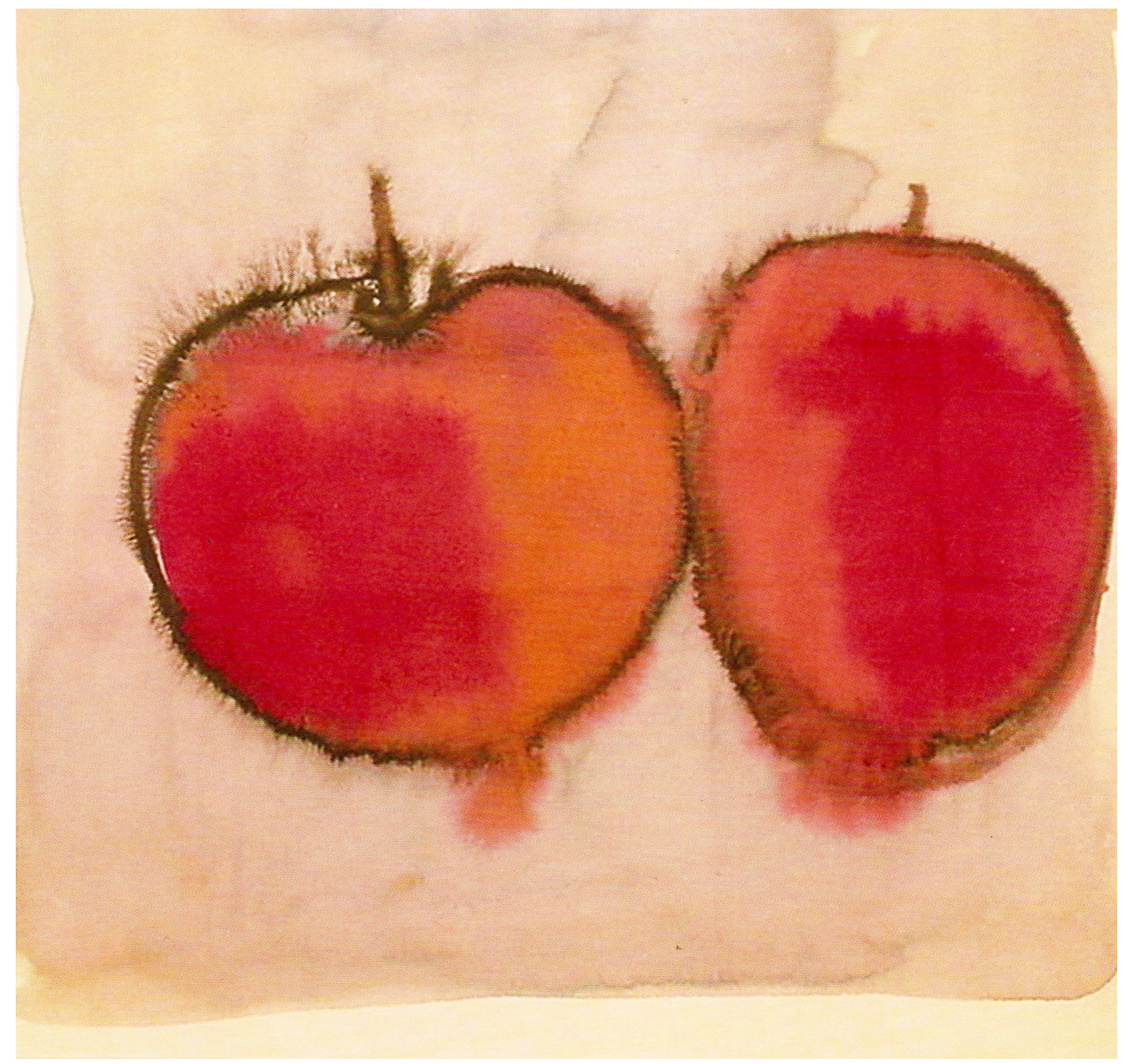

Sem Título, 1960

Ecoline e nanquim sobre papel, $48 \times 38 \mathrm{~cm}$ 


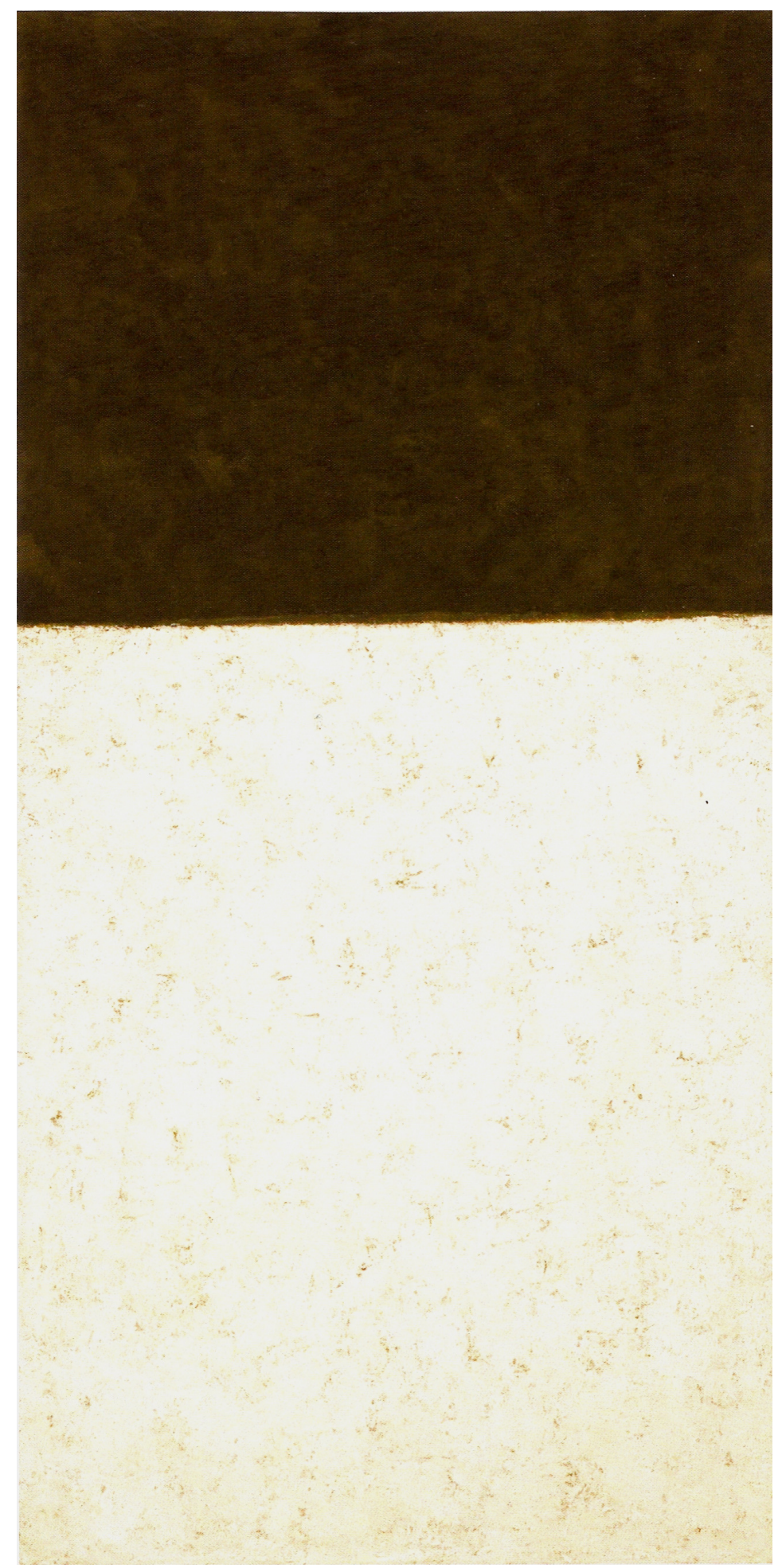

Sem Título, 1963

Técnica mista sobre tela, $148,5 \times 75 \mathrm{~cm}$ 


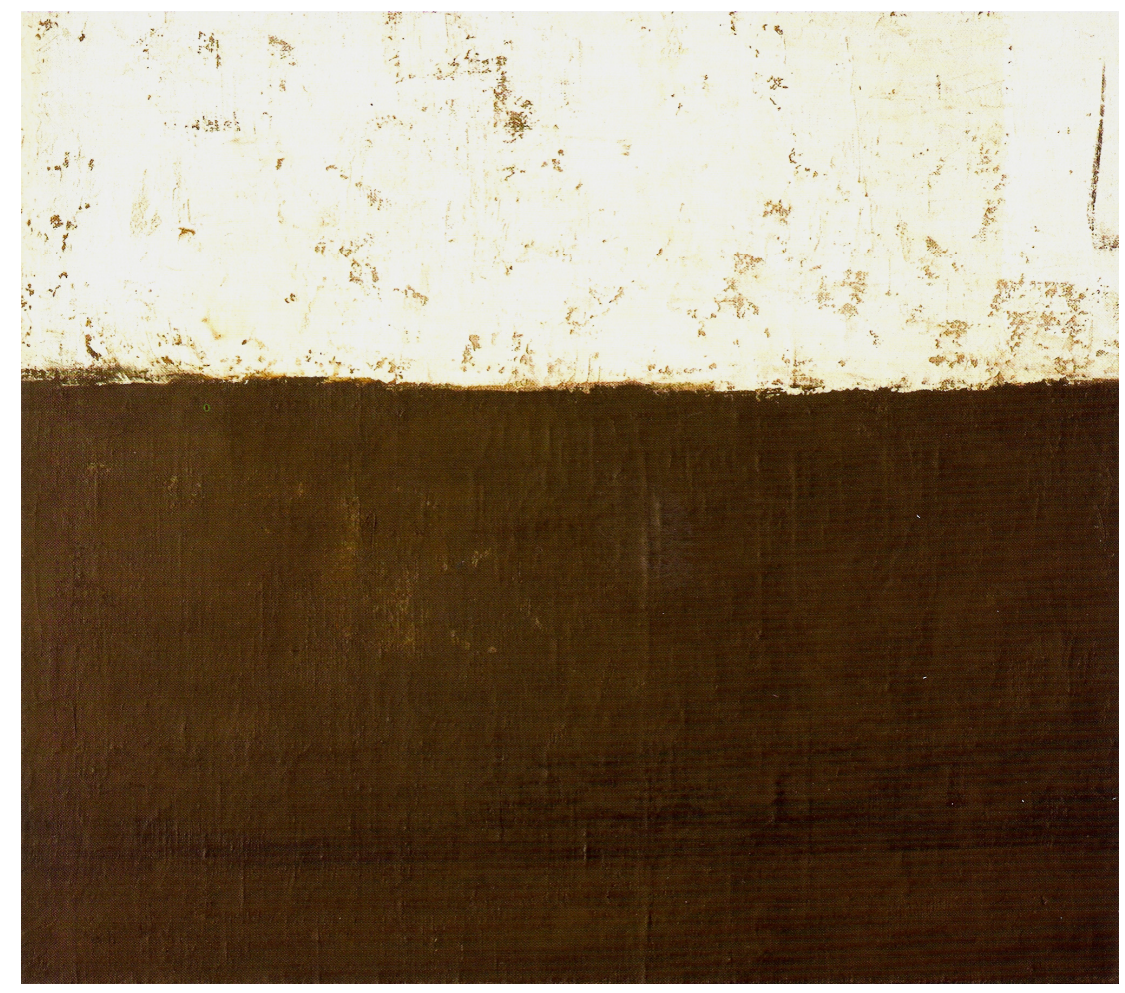

Sem Título, 1964

Têmpera sobre aglomerado, 70 x $40 \mathrm{~cm}$ 


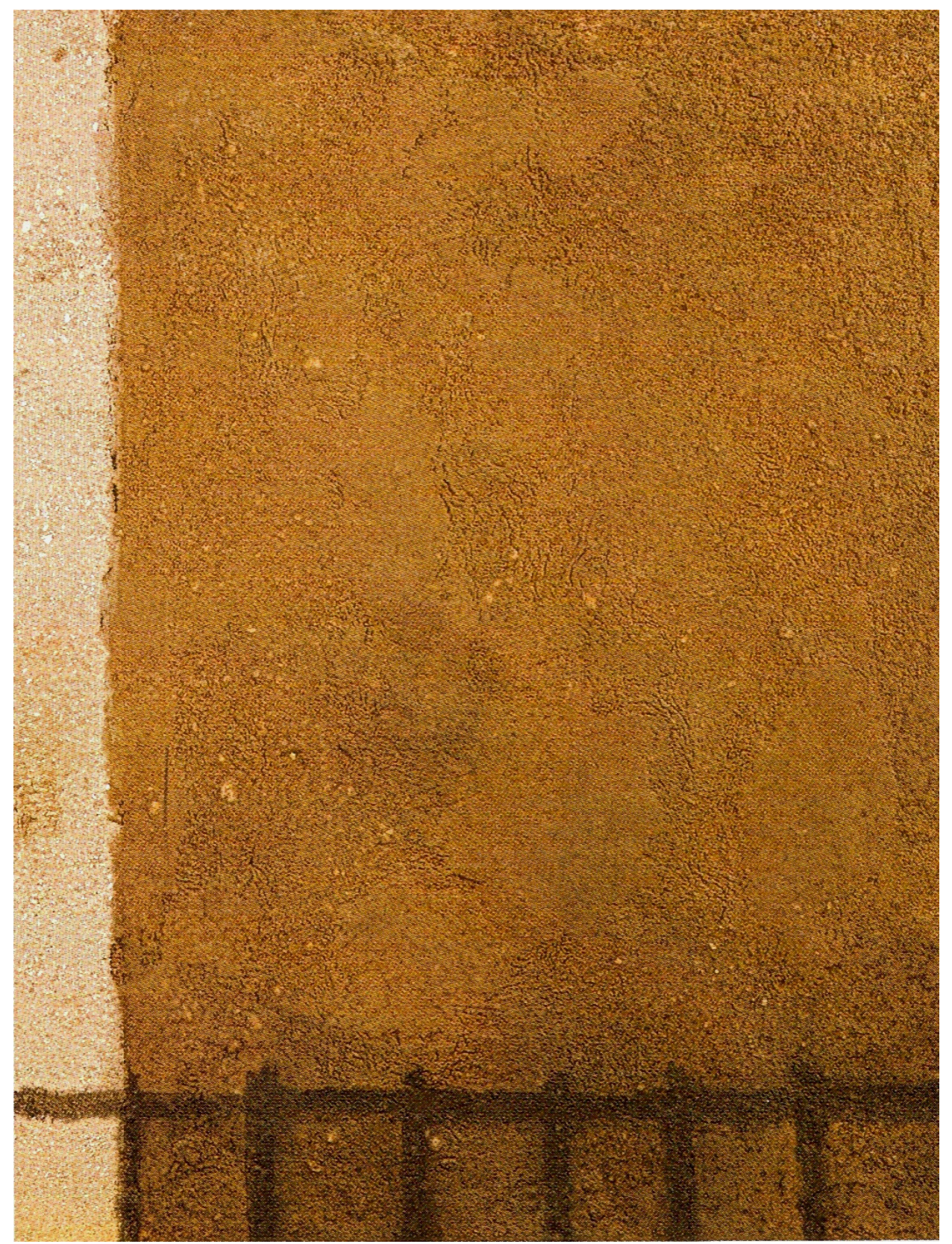

Sem Título, dec. 1960

Têmpera e areia sobre madeira, $40 \times 30 \mathrm{~cm}$ 


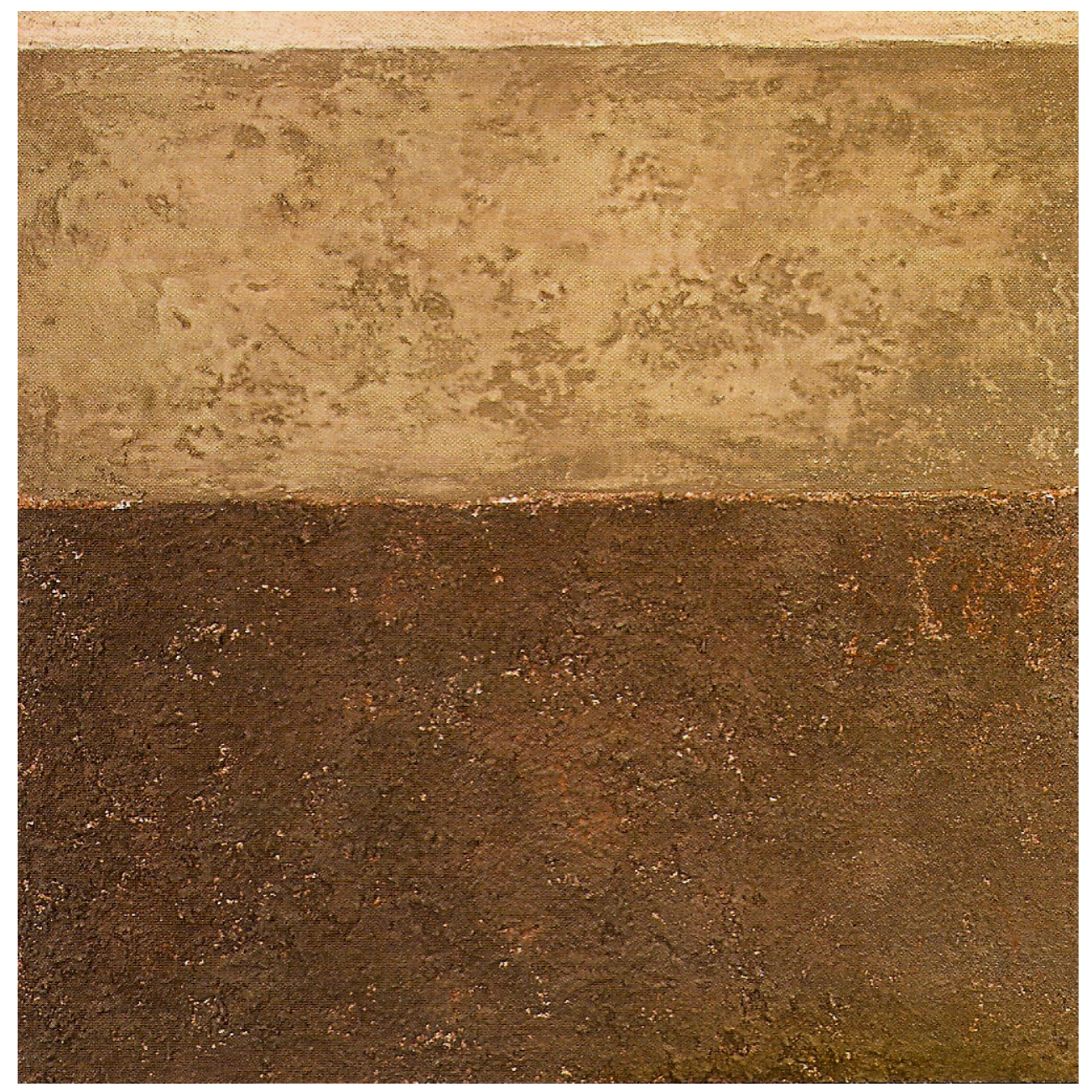

Sem Título, dec. 1960

Têmpera sobre aglomerado, $50 \times 50 \mathrm{~cm}$

Col. Particular, comodato Museu de Arte Contemporânea da Prefeitura de Niterói. 


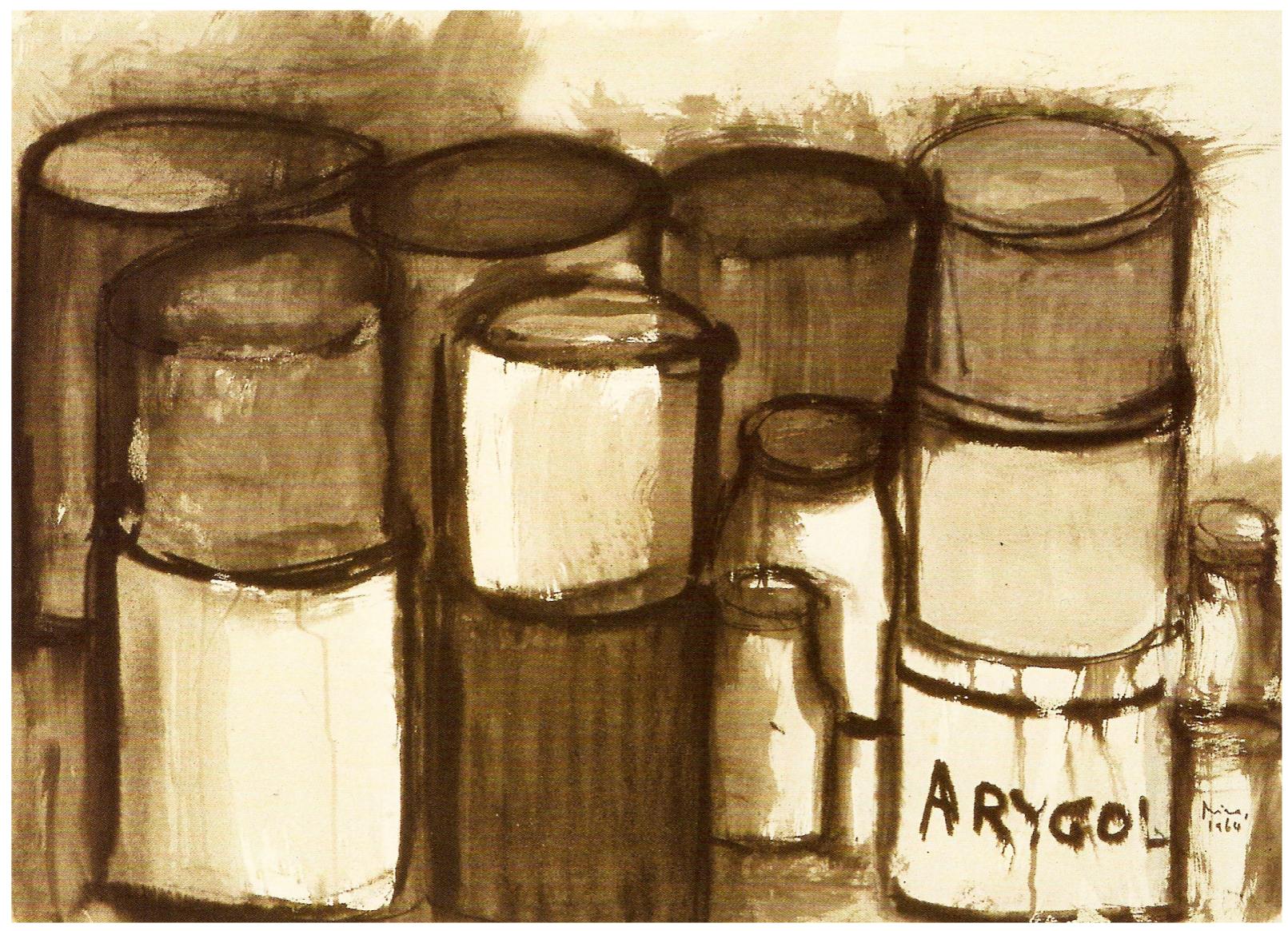

Sem Título, 1964

Nanquim sobre papel, $48 \times 66 \mathrm{~cm}$ 


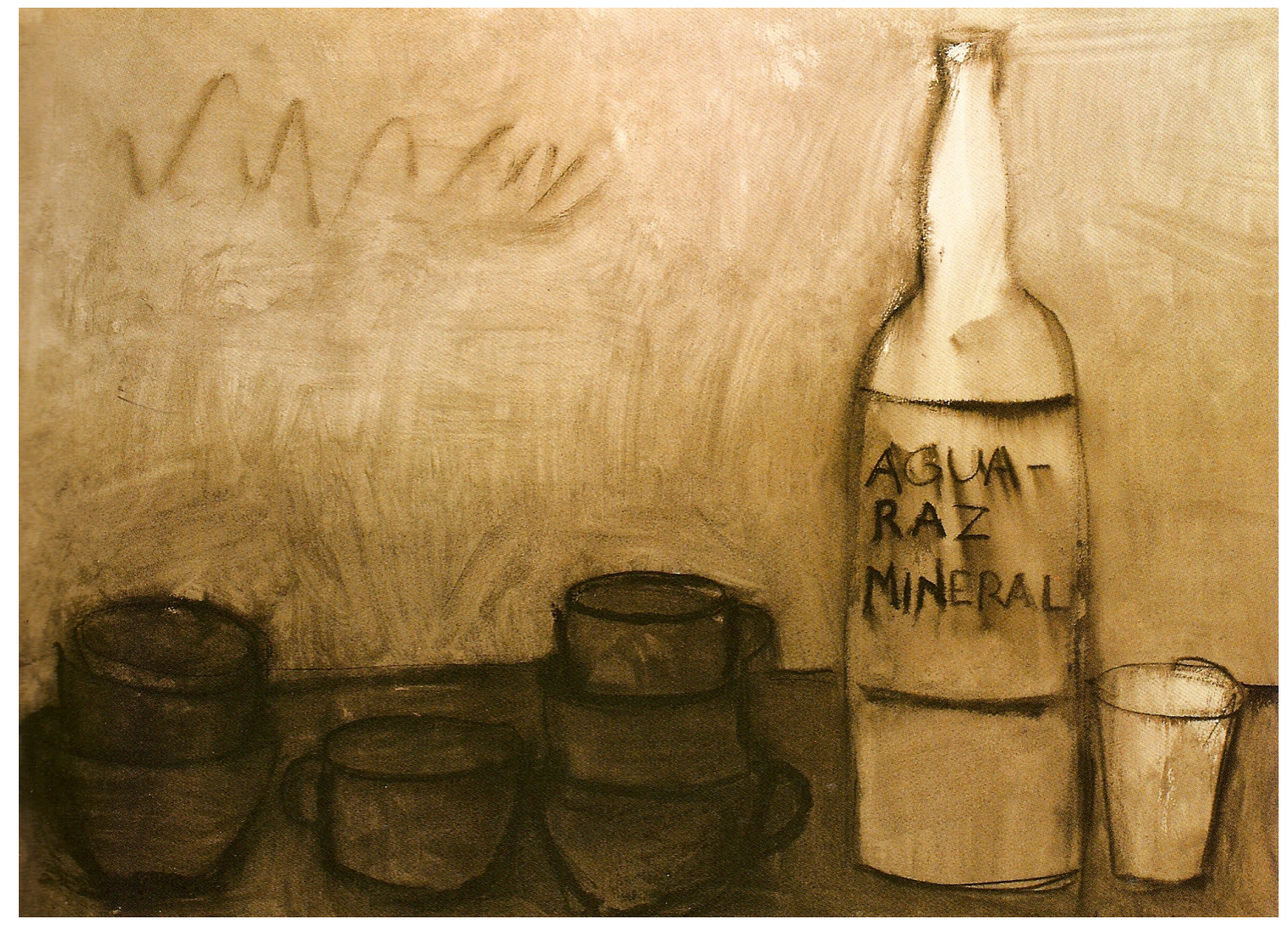

Sem Título, 1964

Técnica mista sobre papel, $48 \times 66 \mathrm{~cm}$ 


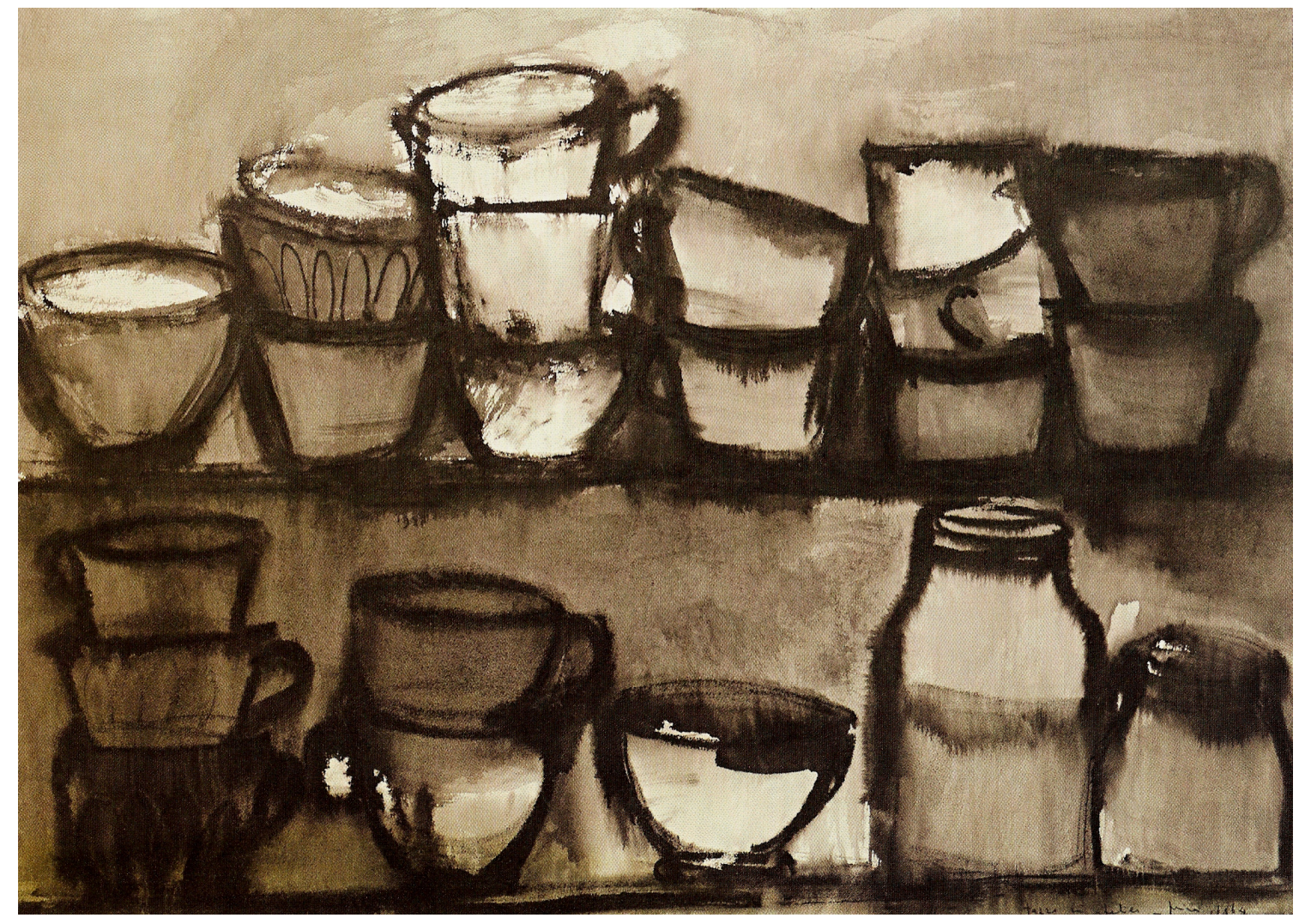

Sem Título, 1964

Nanquim e aguada sobre papel, $48 \times 66 \mathrm{~cm}$ 


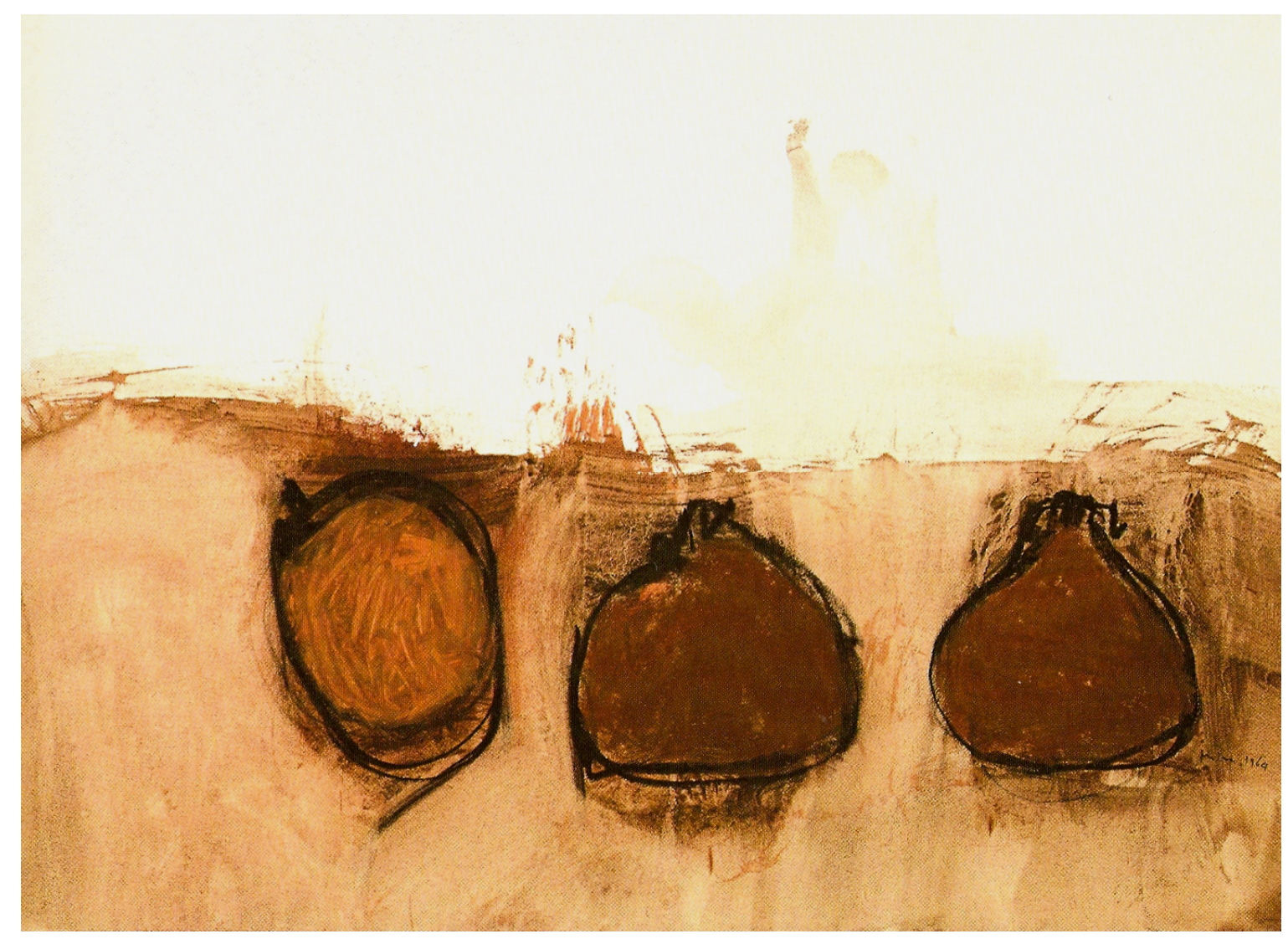

Sem Título, 1964

Carvão, aquarela e guache sobre papel, $48 \times 65,5 \mathrm{~cm}$ 


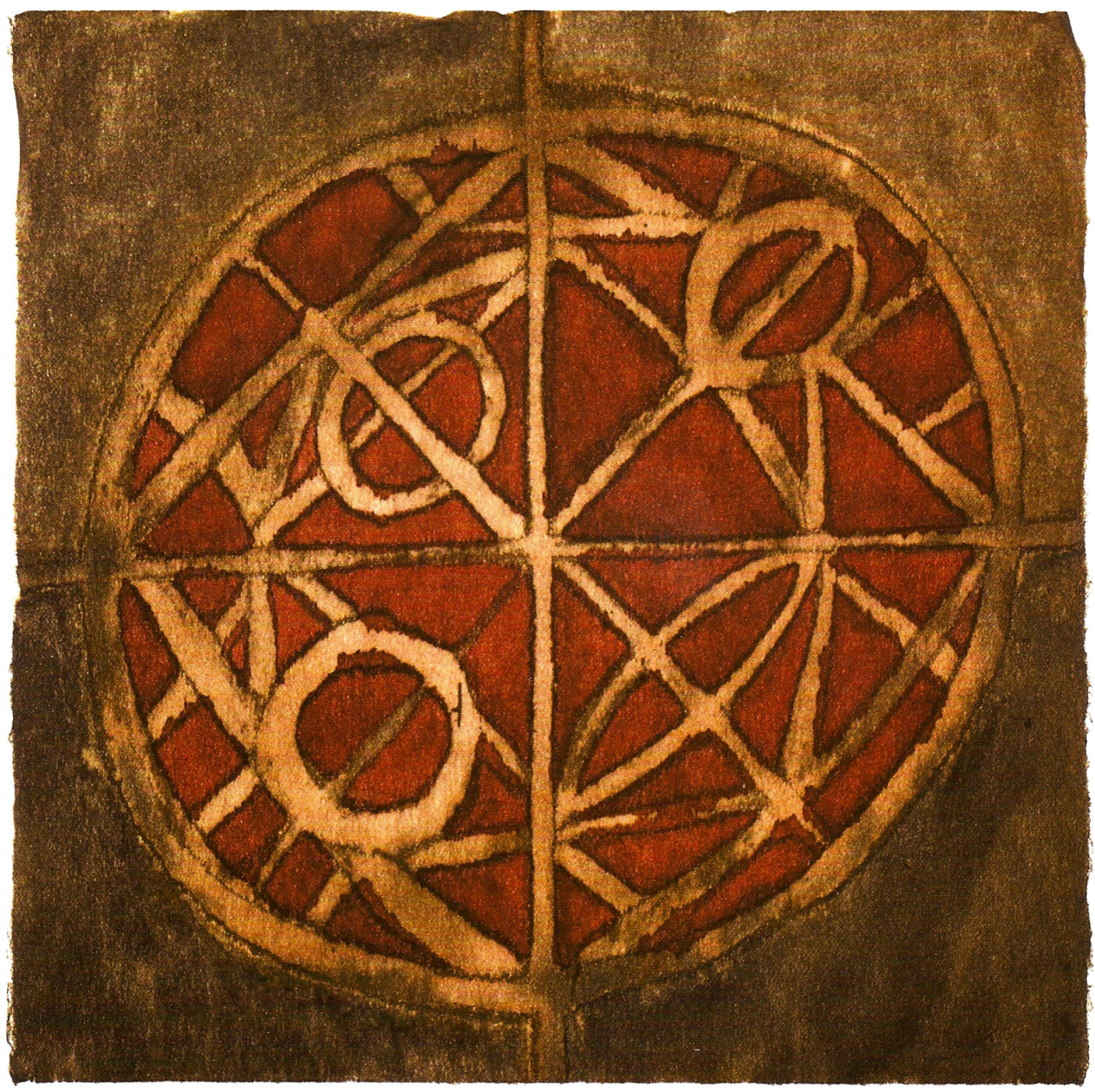

Sem Título, 1960

Ecoline sobre papel japonês, $15 \times 15 \mathrm{~cm}$ 


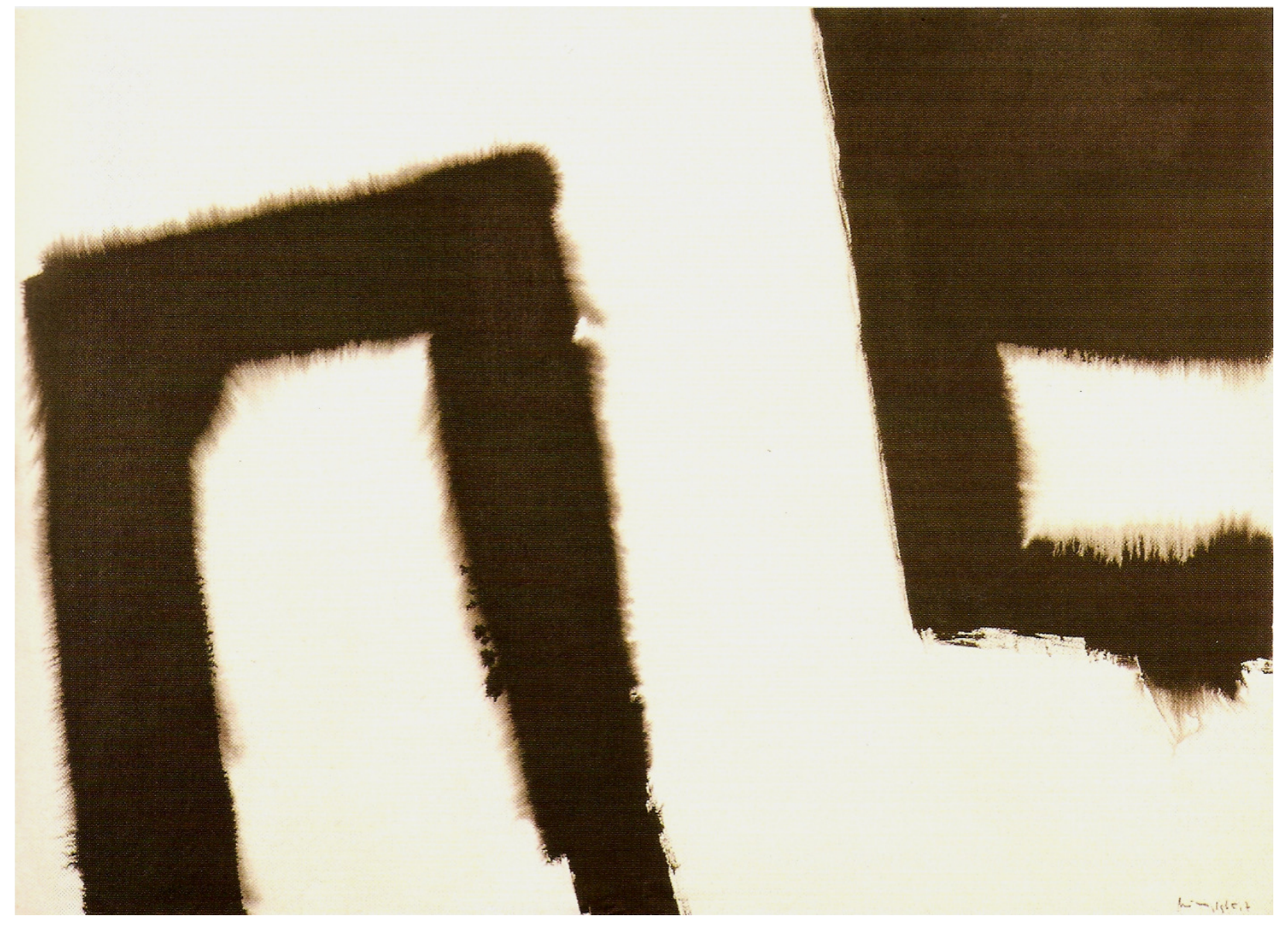

Sem Título (Bomba), 1965

Nanquim sobre papel, $47,5 \times 65,5 \mathrm{~cm}$

Col. Banco BBM 


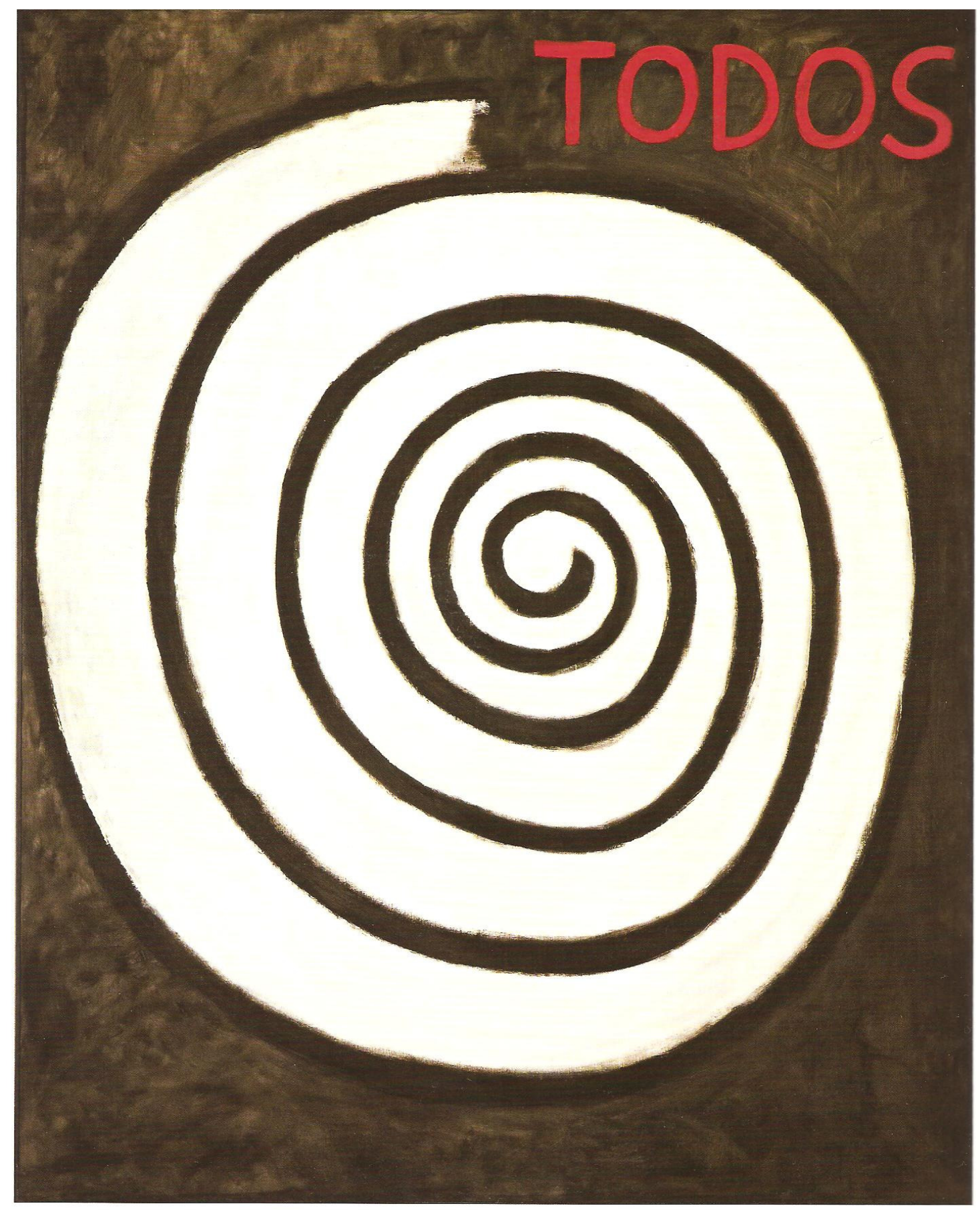

Sem Título (todos), 1964

Óleo sobre tela, $162 \times 130 \mathrm{~cm}$ 


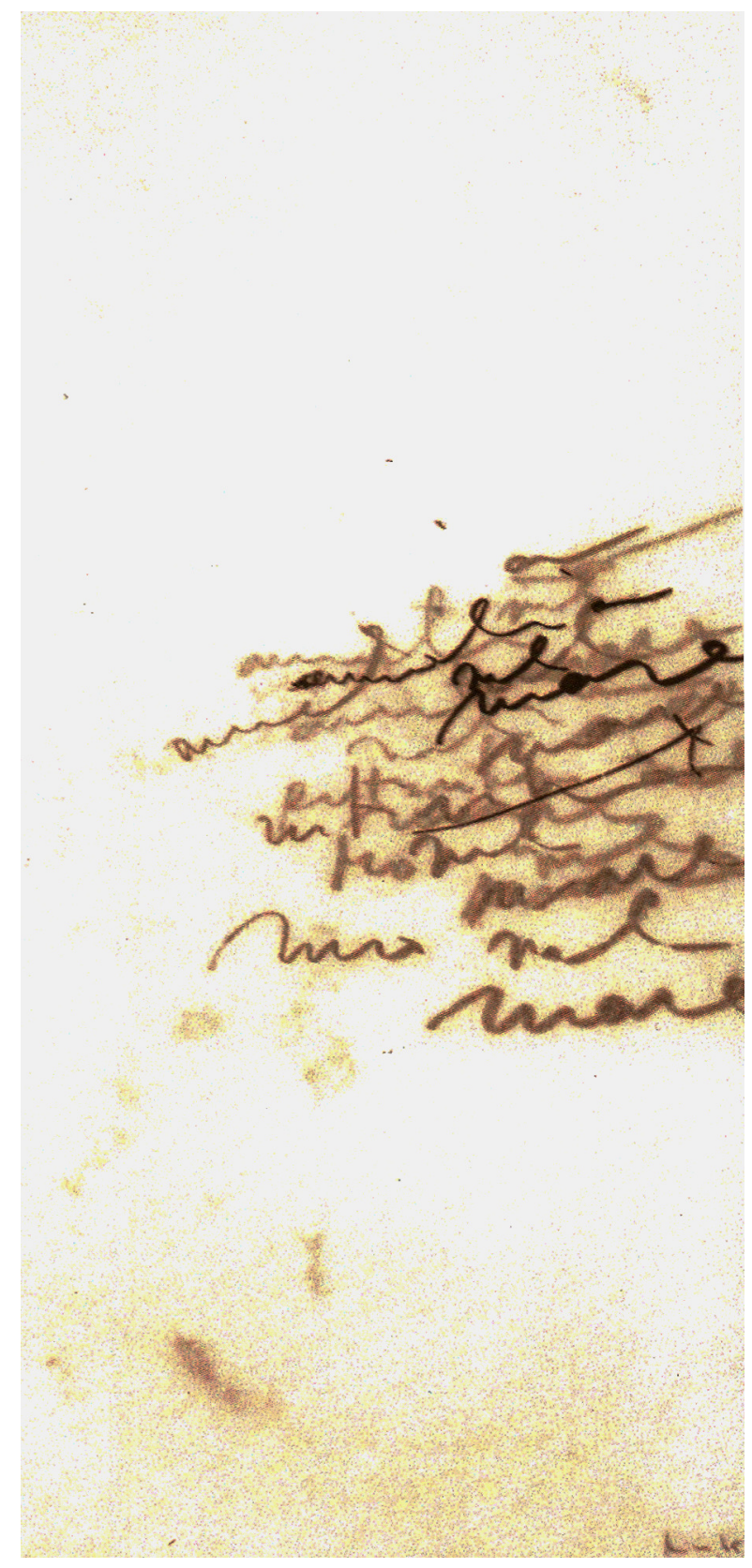

Sem Título, 1964

Óleo sob papel-arroz, $47 \times 23 \mathrm{~cm}$ 


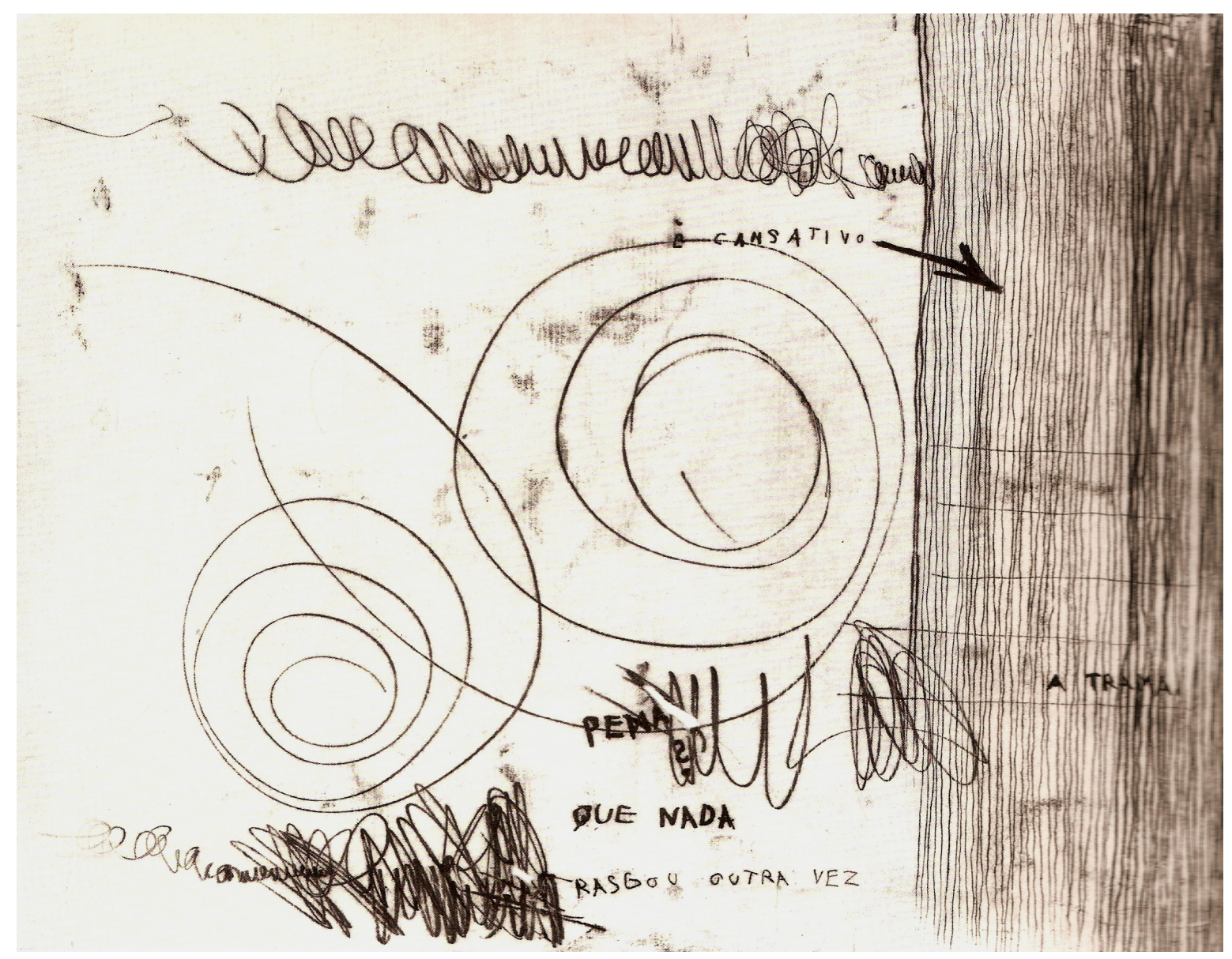

A trama, dec. 1960

Transferência de óleo sobre papel-arroz, 45,1 x 62,2 cm

Col. Museum of Modern Art, Nova York 
190

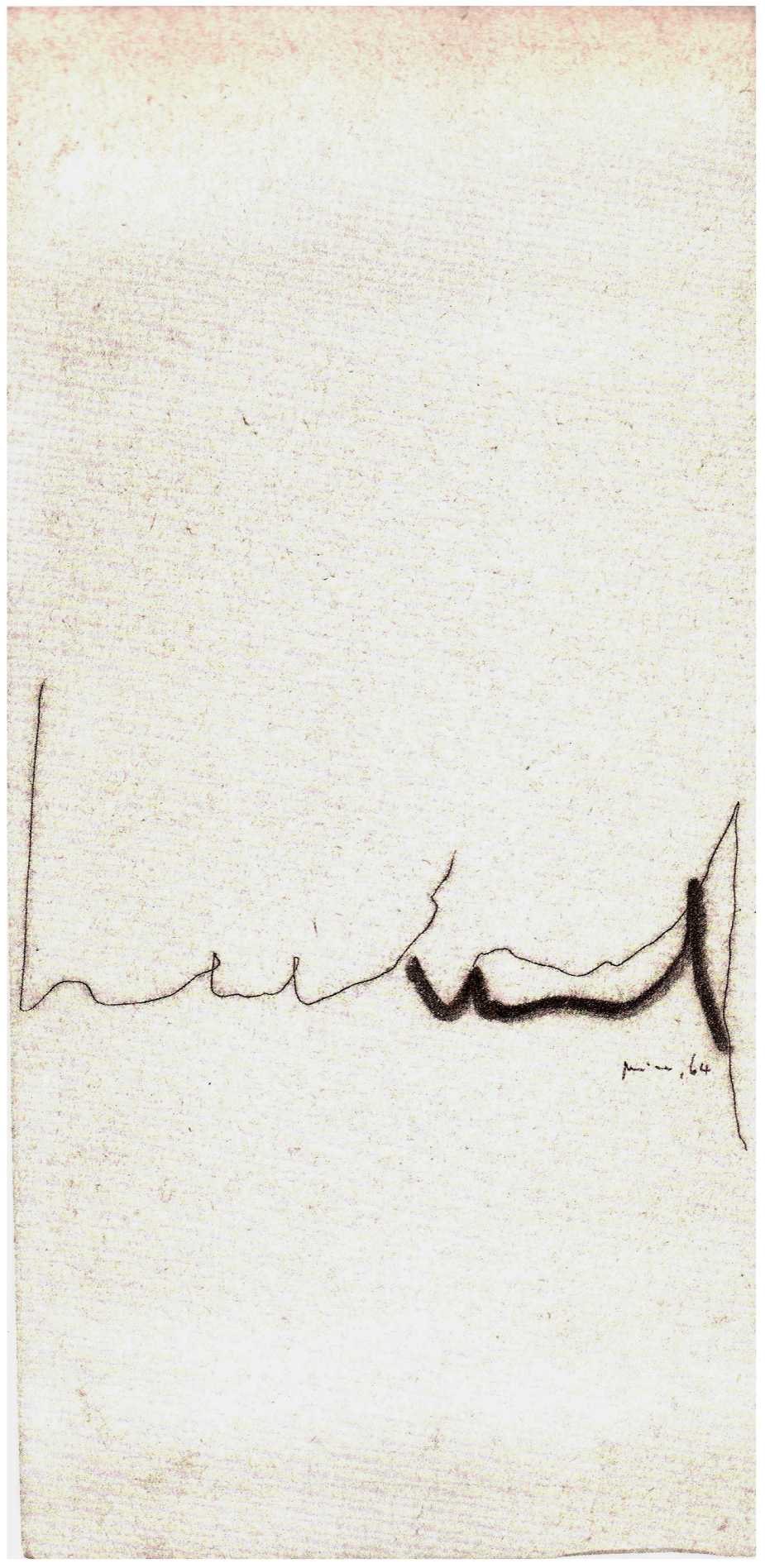

Sem Título, 1964

Transferência de óleo sabre papel-arroz, $47 \times 23 \mathrm{~cm}$ Col. Museum of Modern Art, Nova York 


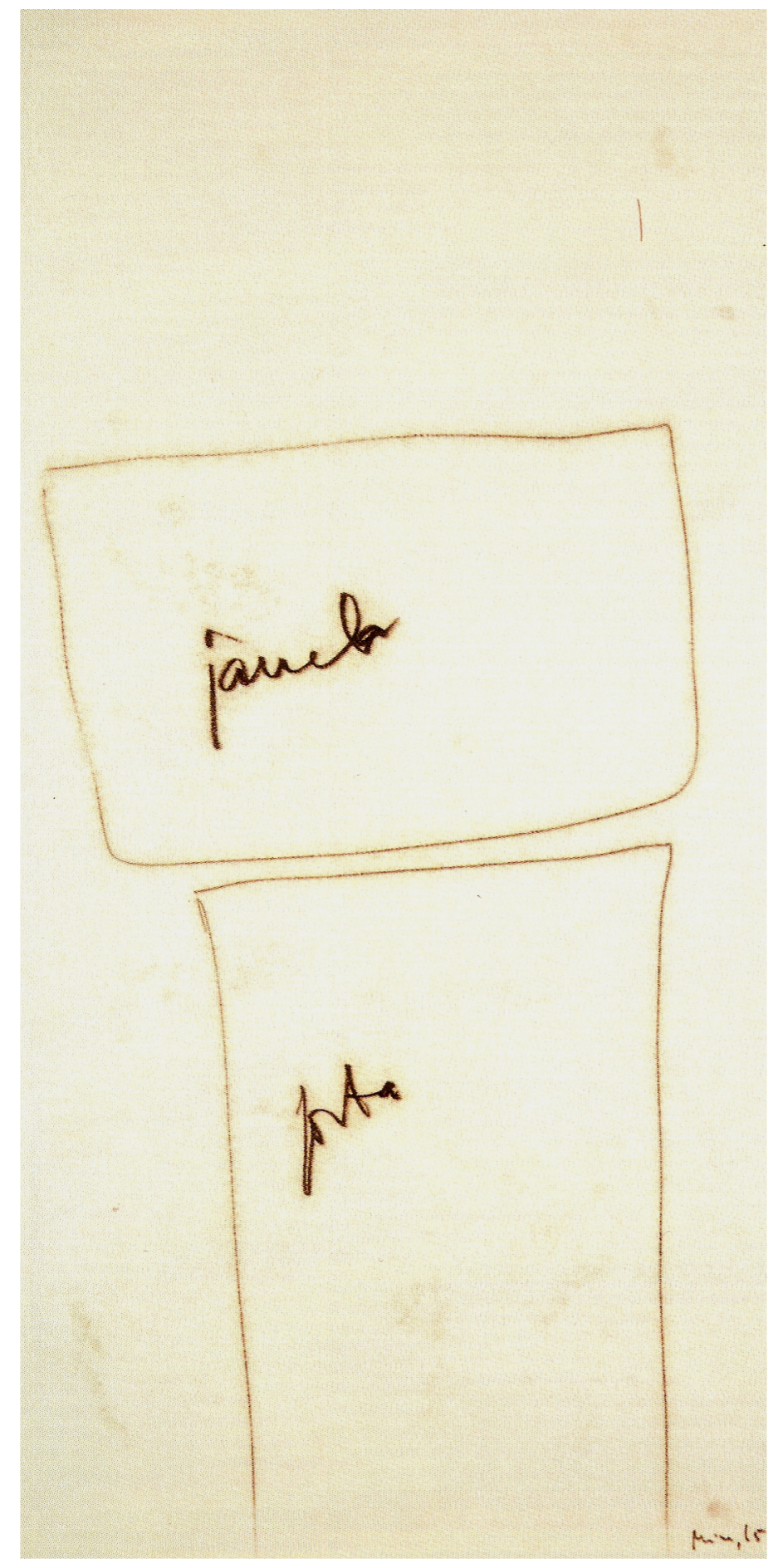

Sem Título, 1965

Transferência de Óleo sobre papel, 46 × 23 cm 


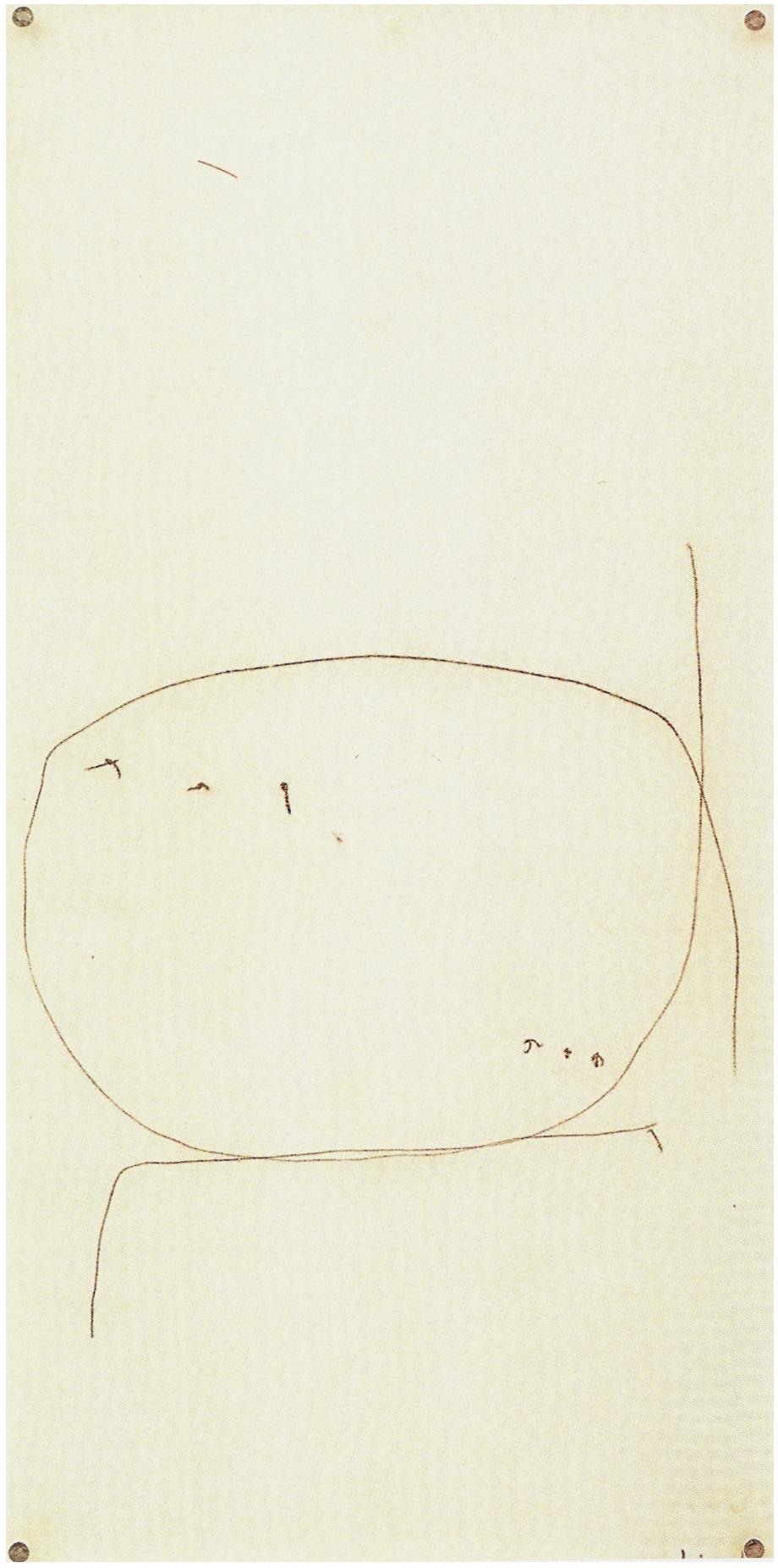

Sem Título, 1965

Transferência de Óleo sobre papel, 46 × 23 cm 


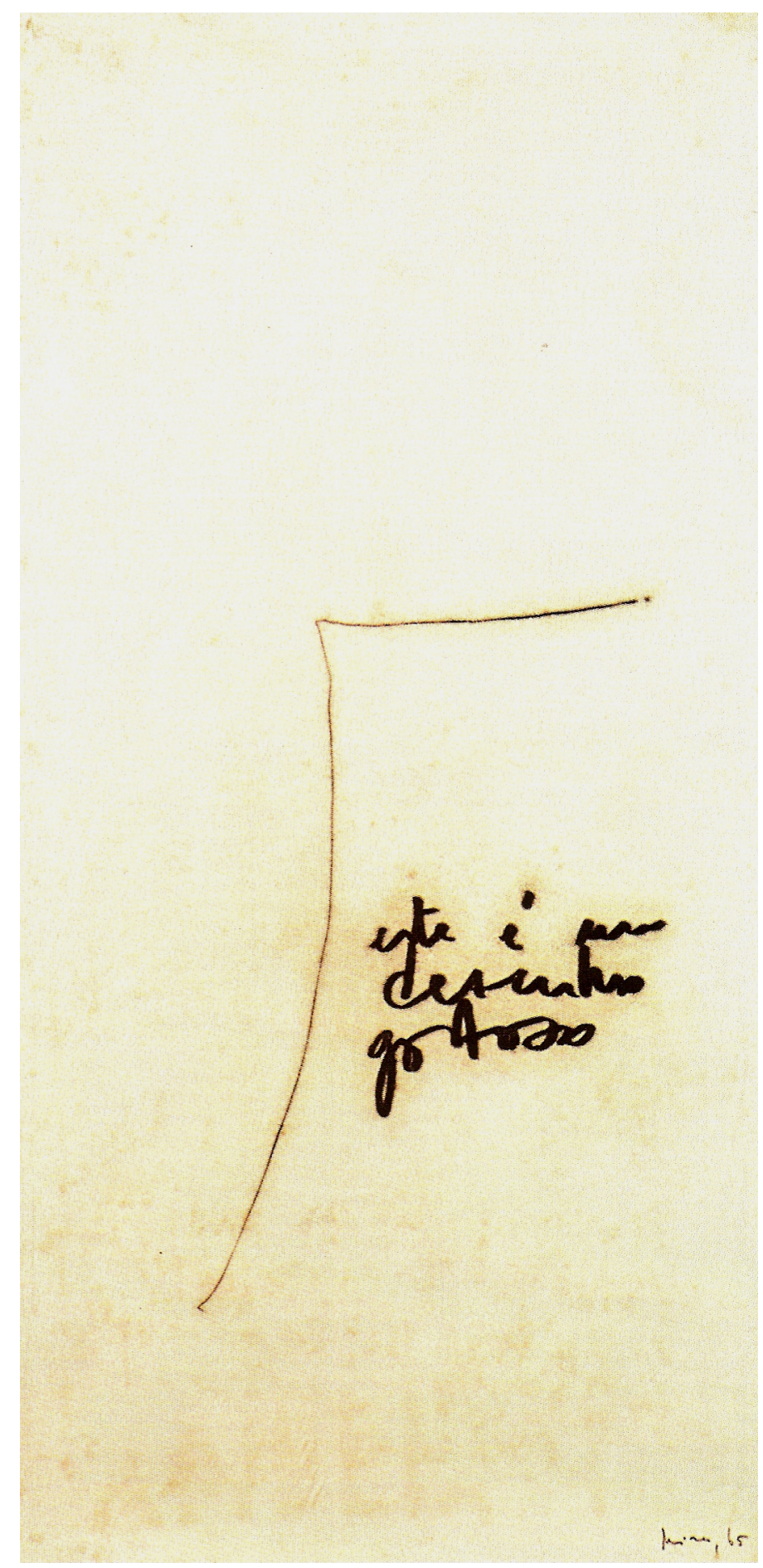

Sem Título, 1965

Transferência de Óleo sobre papel, $47 \times 23 \mathrm{~cm}$

Col. Museu de Arte Moderna de São Paulo 


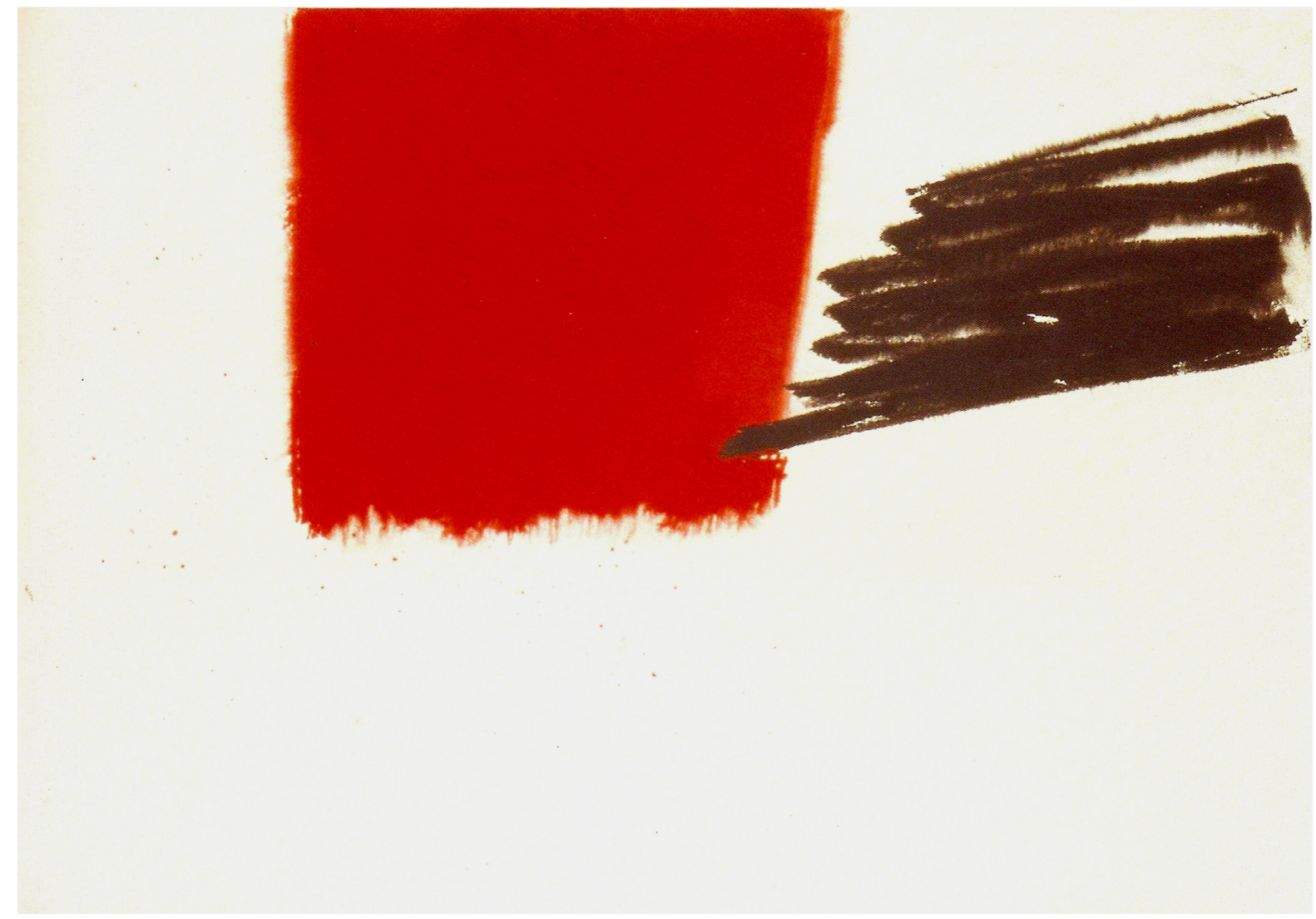

Sem Título, 1965

Ecoline e nanquim sobre papel, $48 \times 66 \mathrm{~cm}$ 


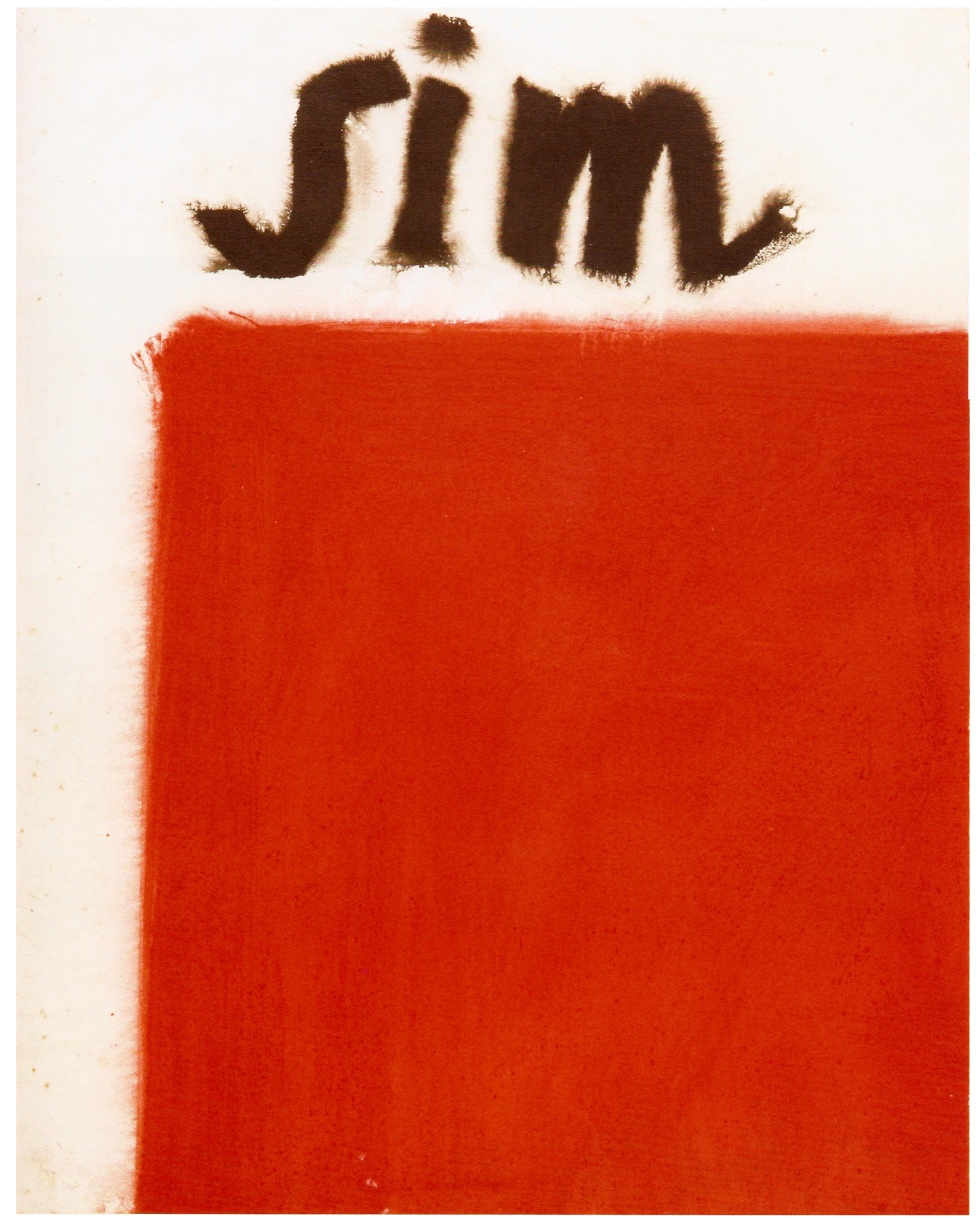

Sem Título (Sim), dec. 1960

Ecoline e nanquim sobre papel, $48 \times 38 \mathrm{~cm}$ 


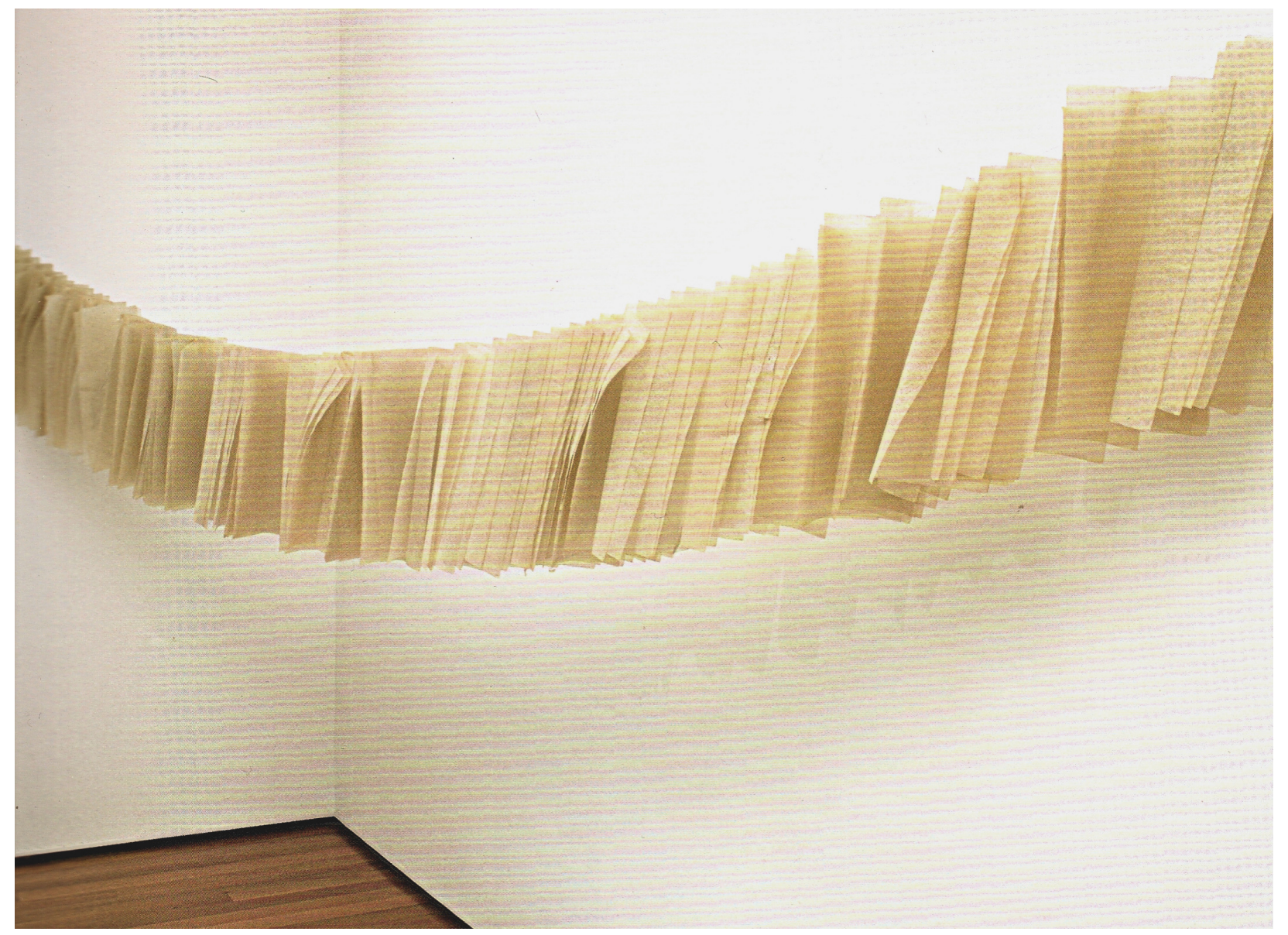

Trenzinho, 1965

Papel-arroz e fio de náilon, dimensões variáveis

Col. Museum of Modern Art, Nova York 


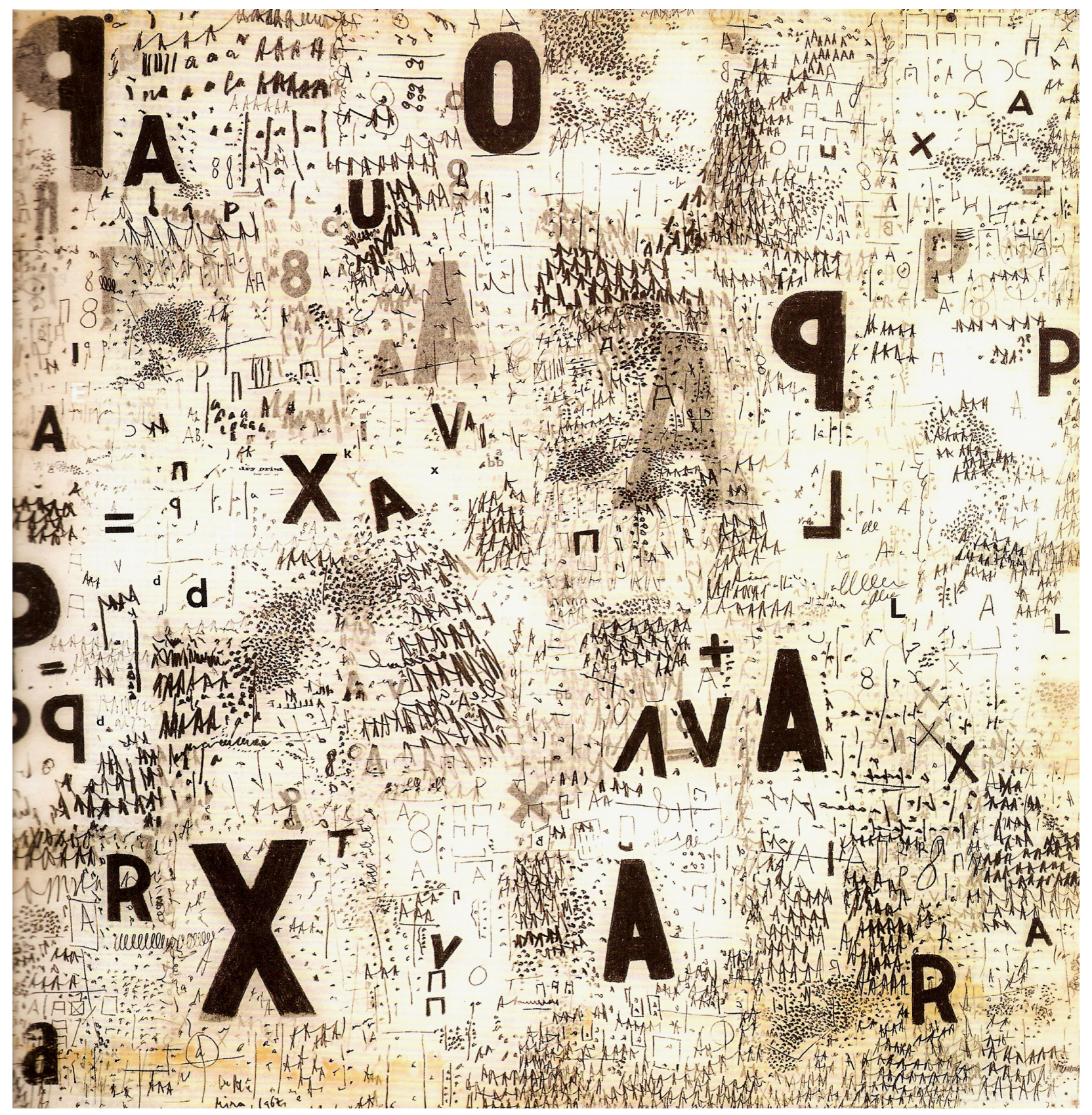

Sem Título (Objetos Gráficos), 1967

Grafite e óleo sobre papel entre placas de acrílico, 99,8 x 99,8 × $1 \mathrm{~cm}$ 


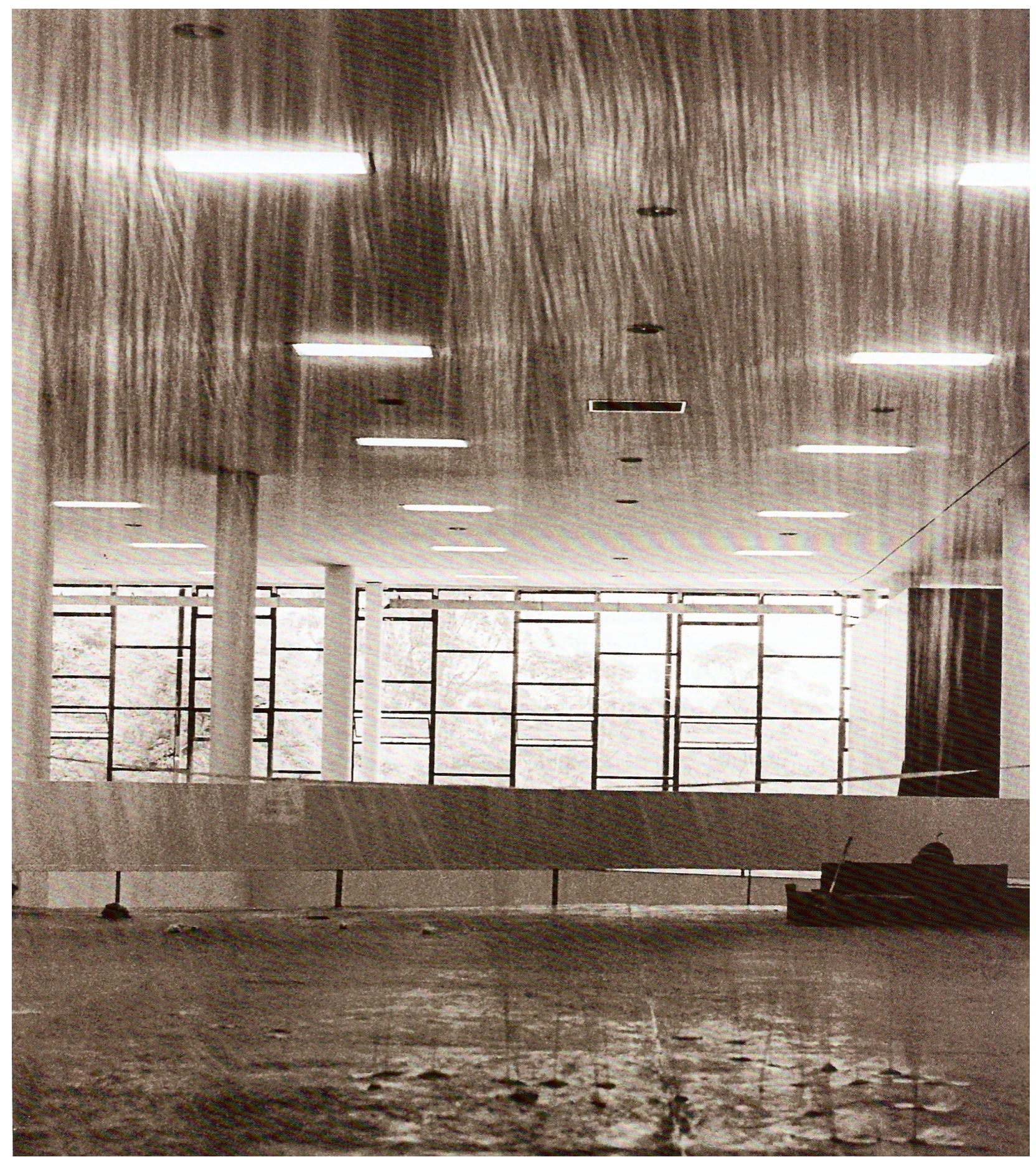

Remontagem da instalação Ondas paradas de probabilidade, [10a Bienal de São Paulo, 1969], 22a Bienal de São Paulo, 1994, dimensões variáveis 

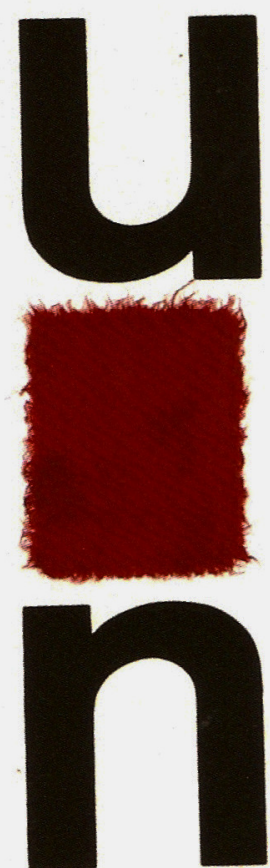

Sem Título(toquinho), 1972

Letraset sobre papel japonês, $49 \times 25,4 \mathrm{~cm}$

Col. Museu de Arte Contemporânea da Universidade de São Paulo, São Paulo 


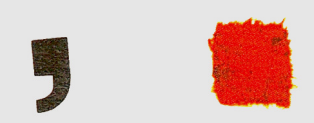

Sem Título (toquinho), 1972

Letraset, papel tingido sobre papel japonês, 49 × 25,4 cm 


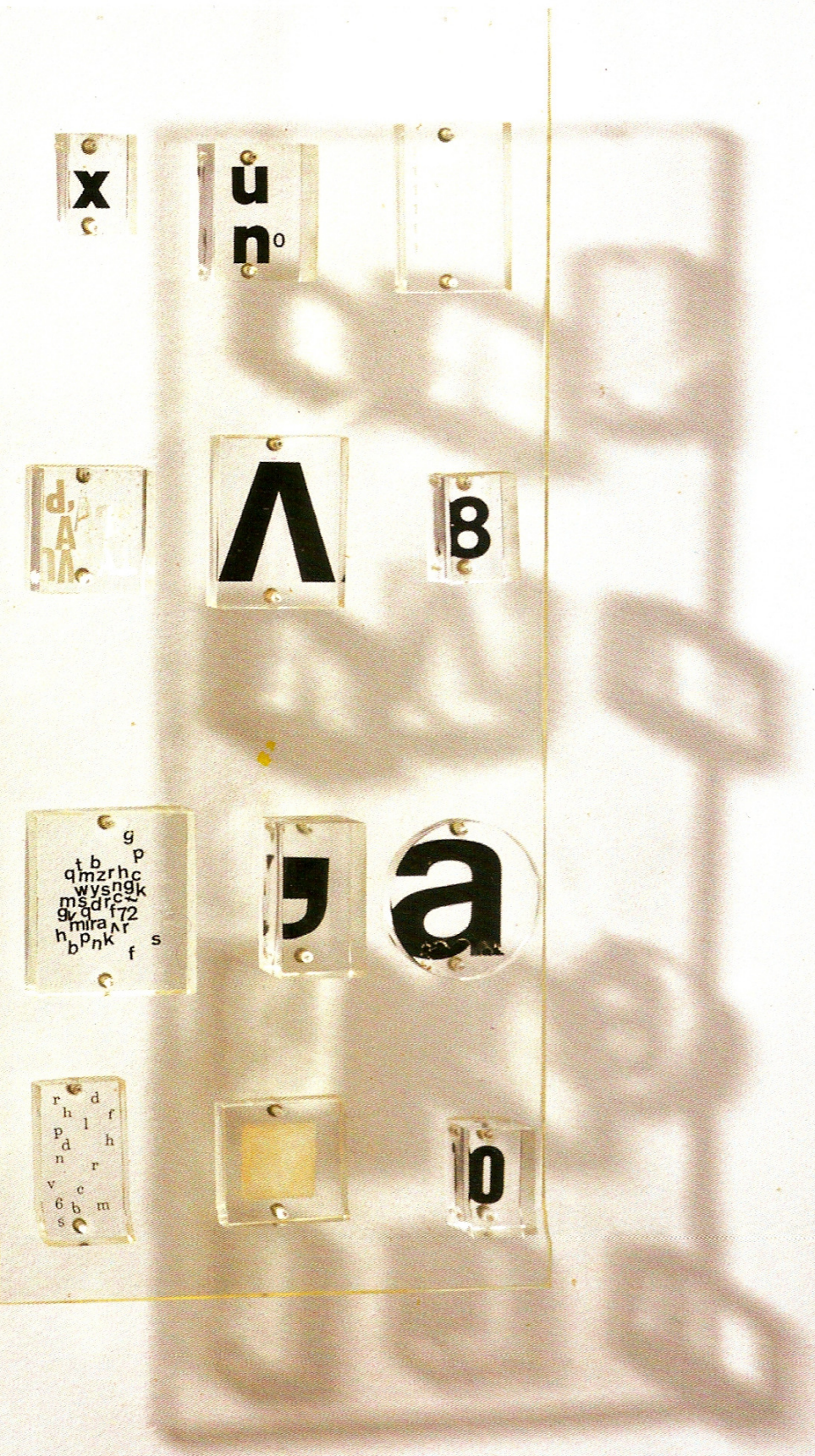

Sem Título (Toquinho), 1972

Letraset e papel artesanal tingido sobre blocos de acrílico montados sobre placa de acrílico, $46,5 \times 20,5 \times 3 \mathrm{~cm}$ 


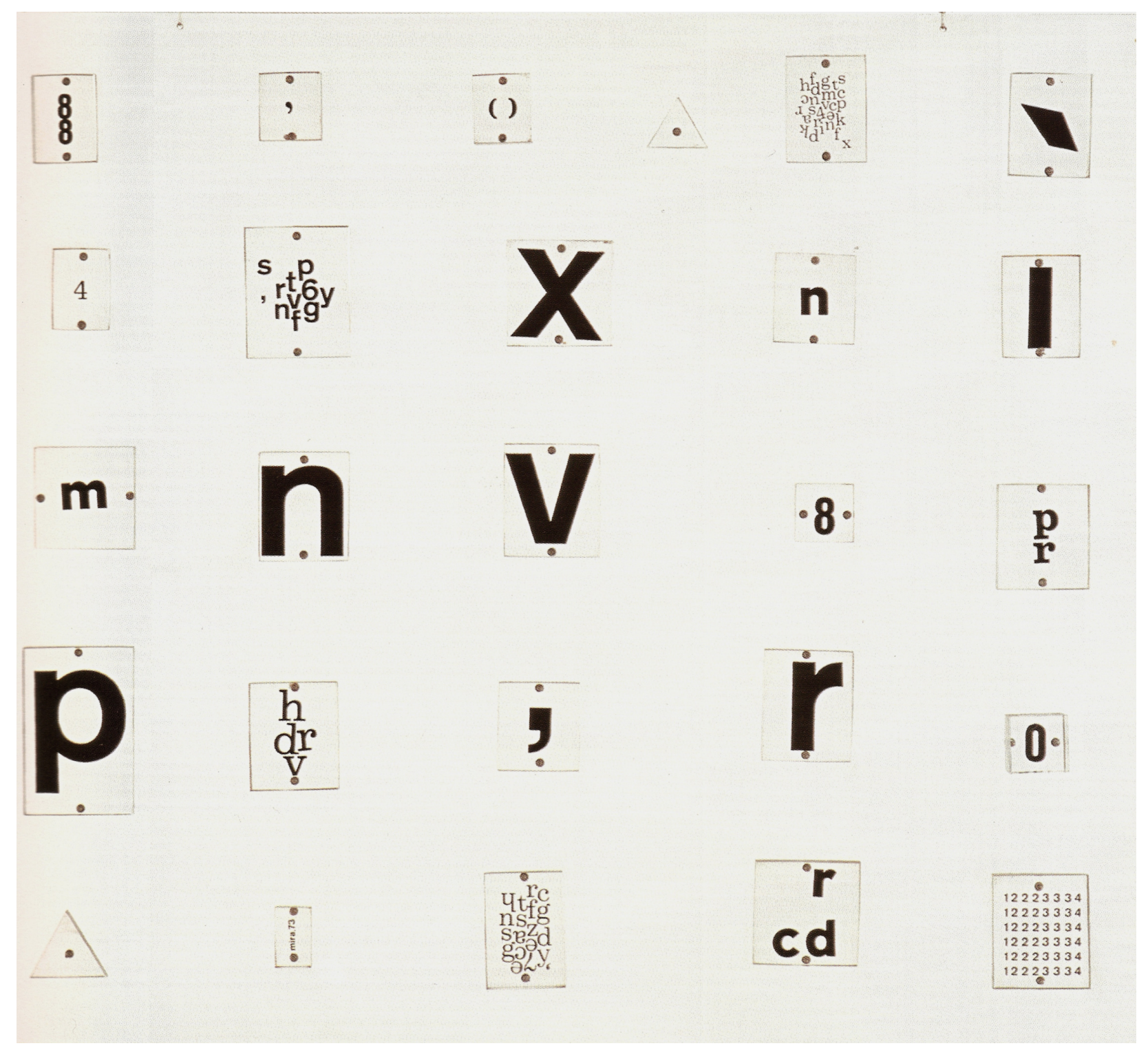

Sem Título (Toquinho), 1973

Letraset sobre blocos de acrílico montados sobre placa de acrílico, 50 × 56,6 x 1,4 $\mathrm{cm}$ 


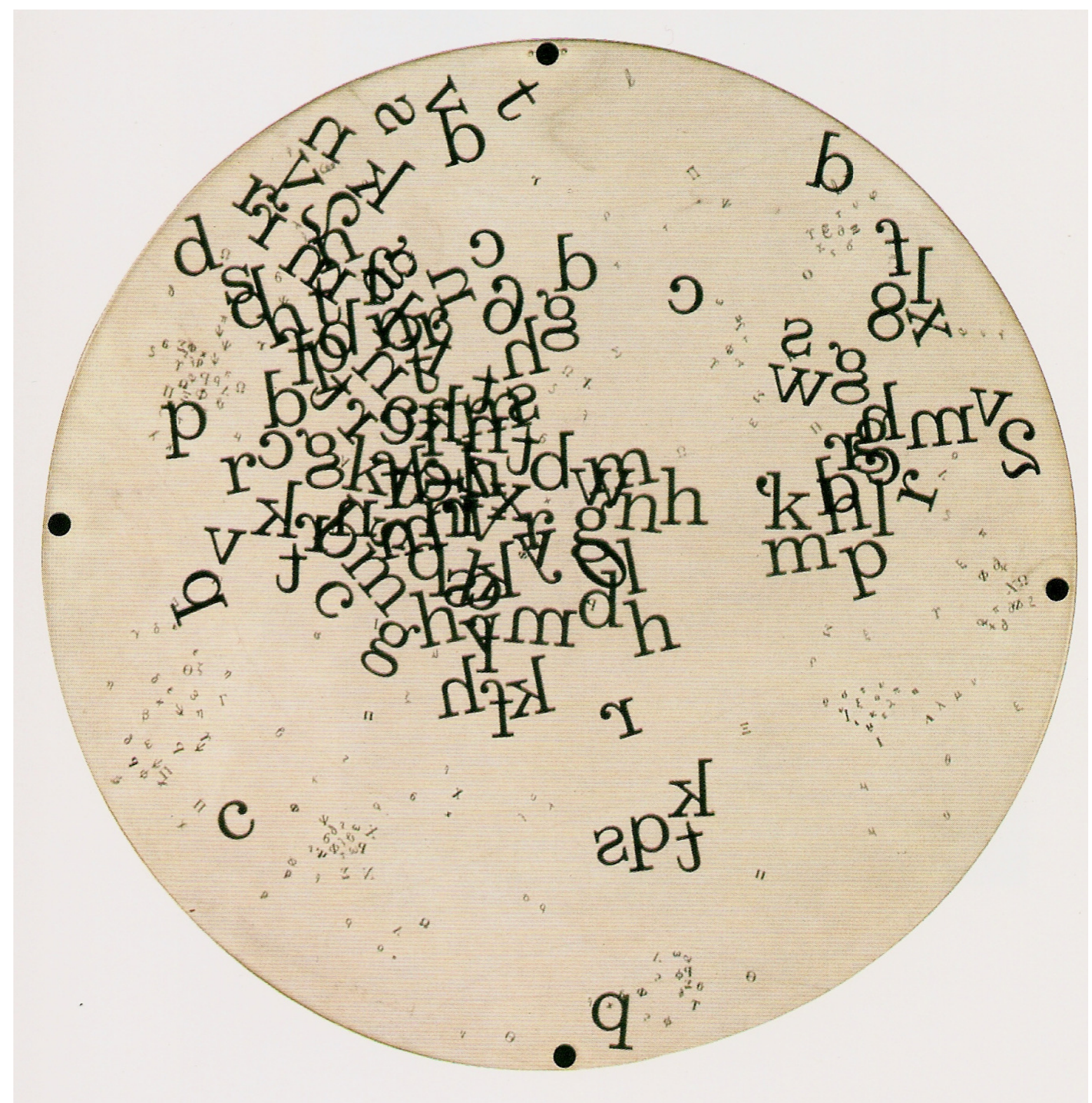

Sem Título, dec. 1972

Letraset entre placas de acrílico fosqueada, $22 \times 0,5 \mathrm{~cm}$ 


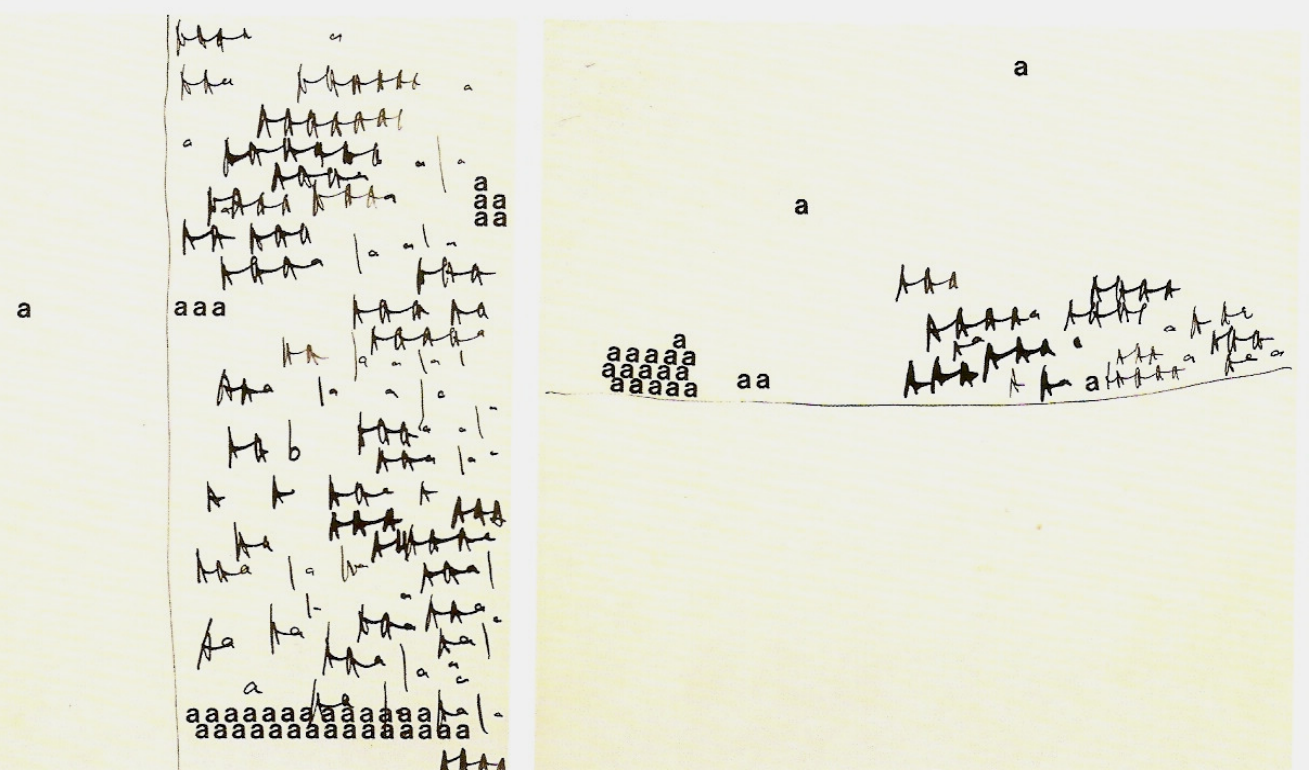

Sem Título, dec. 1970

Nanquim e letraset sobre papel, $16 \times 16 \mathrm{~cm}$ 


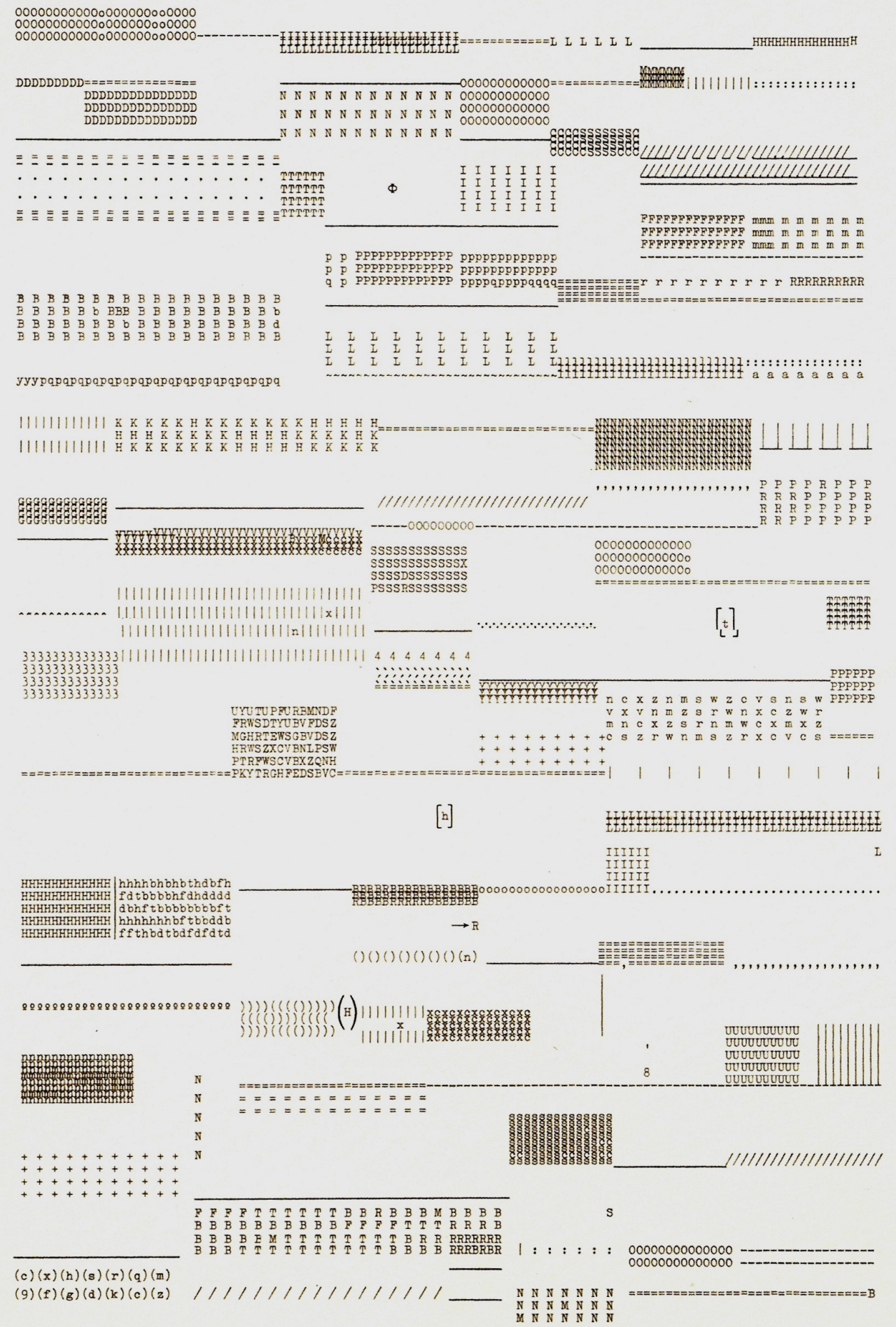



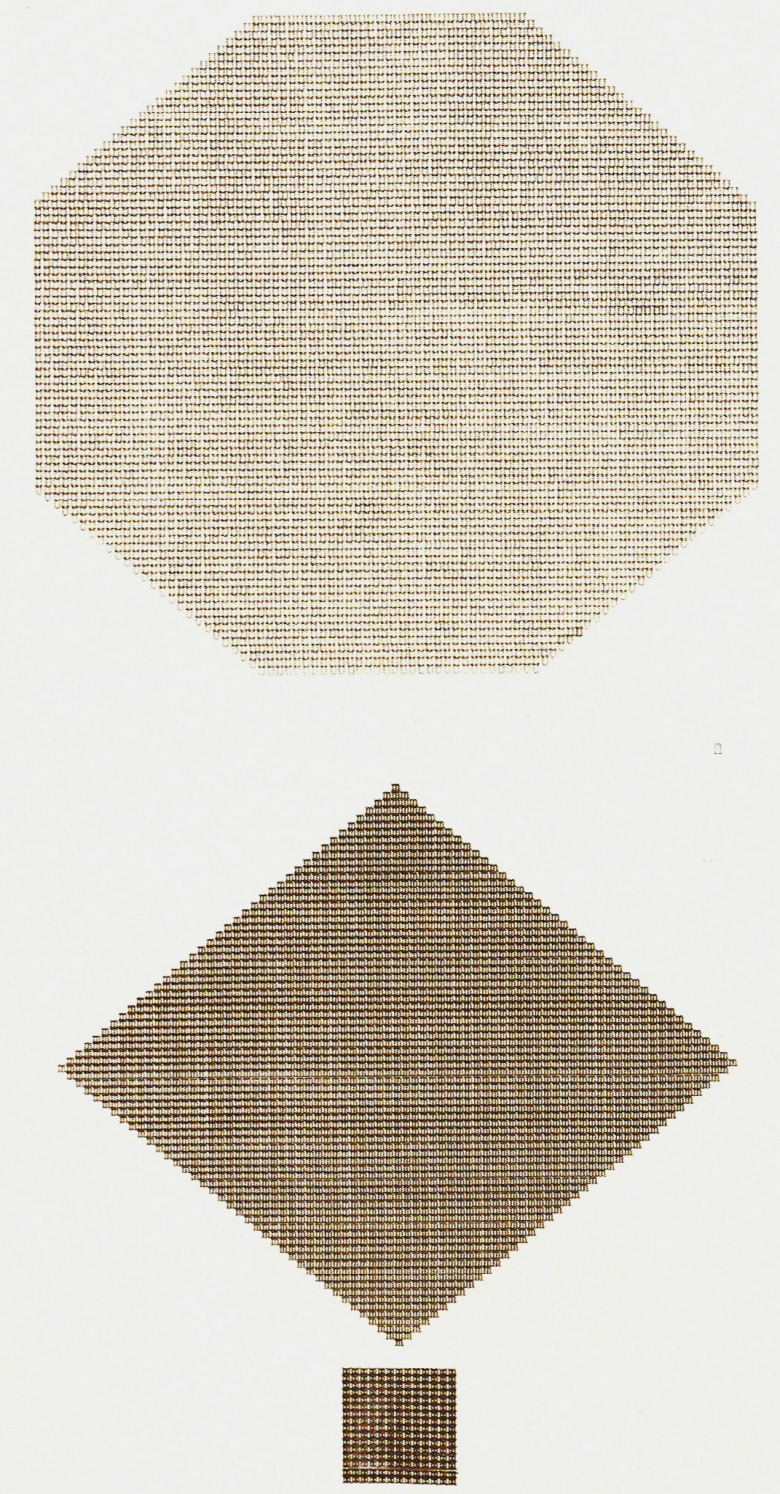

Datiloscritos, 1974

Datilografia, letraset sobre papel, $50,8 \times 36,4 \mathrm{~cm}$

Col. Museu de Arte Contemporânea da Universidade de São Paulo 

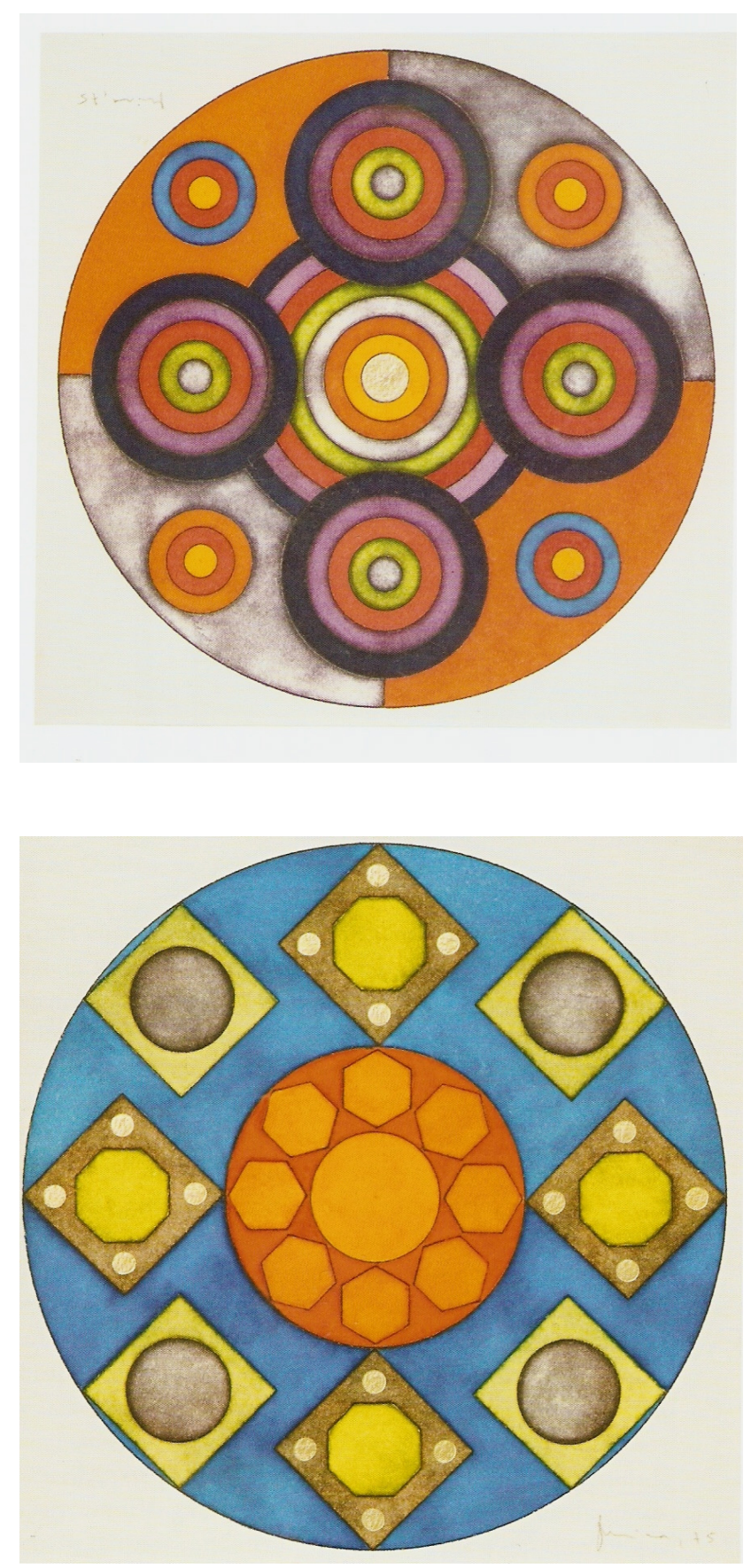

Mandalas, dec. 1974

Nanquim e ecoline sobre papel, $18 \times 18 \mathrm{~cm}$ 

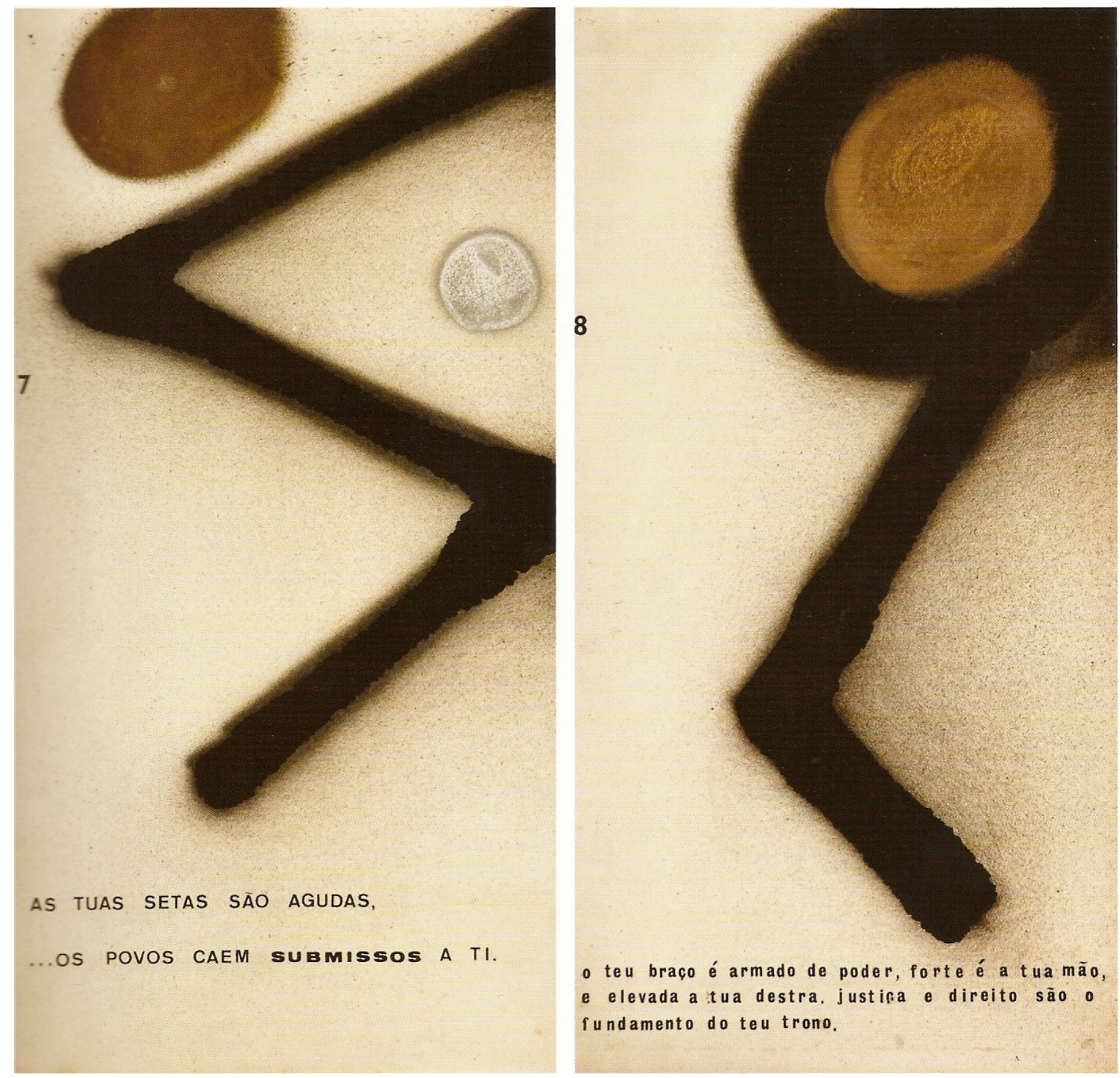

Série Homenagem ao Deus-pai do Ocidente, dec. 1975 Tinta spray, letras autocolantes sobre papel, $46 \times 23 \mathrm{~cm}$ 


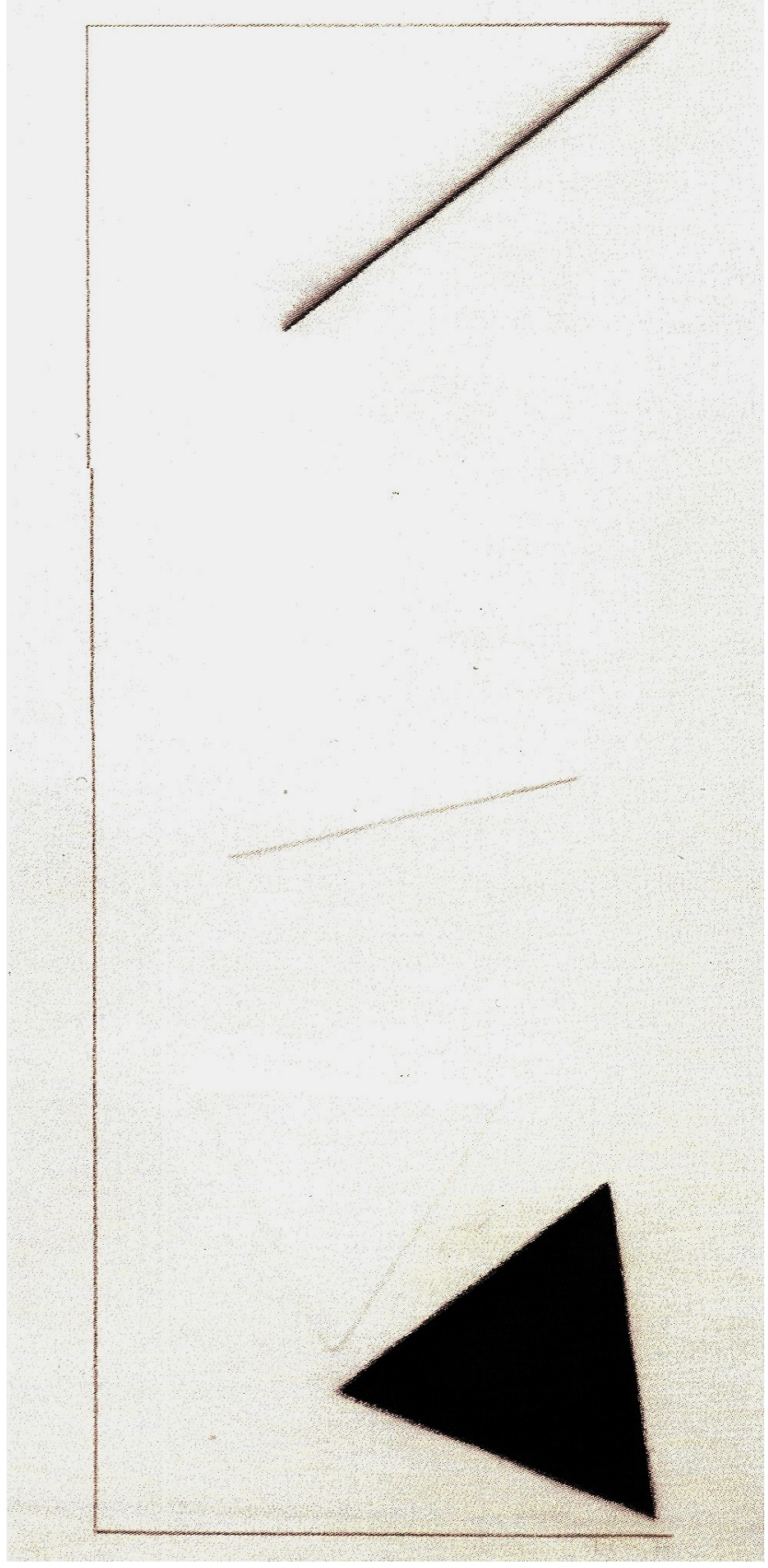

Sem Título, 1980

Carvão e relevo seco sobre papel, 45,5 x $23 \mathrm{~cm}$ 


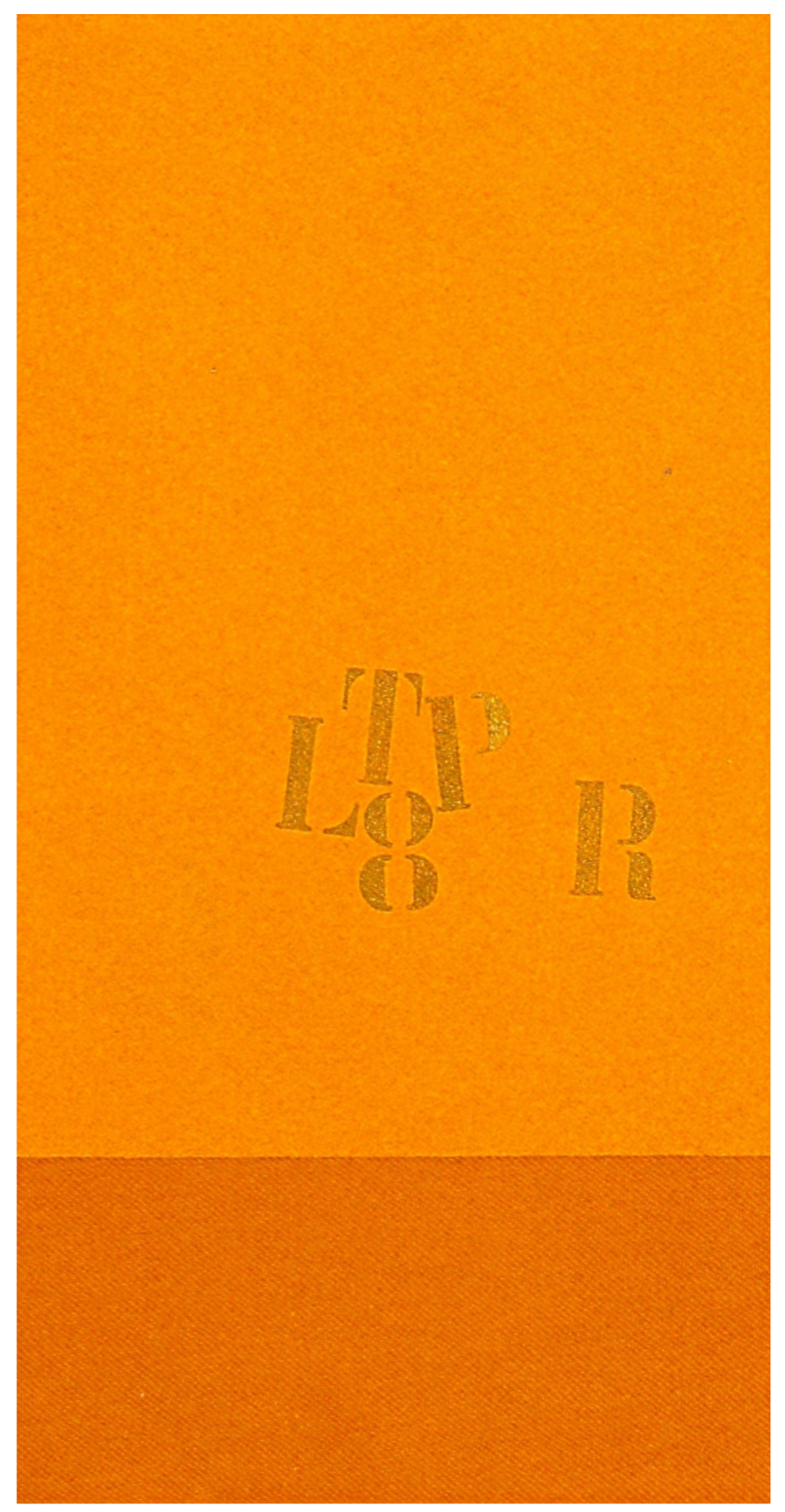

Sem Título, dec. 1981

Têmpera acrílica e folha de ouro sobre tela, $46 \times 23,5 \mathrm{~cm}$ 


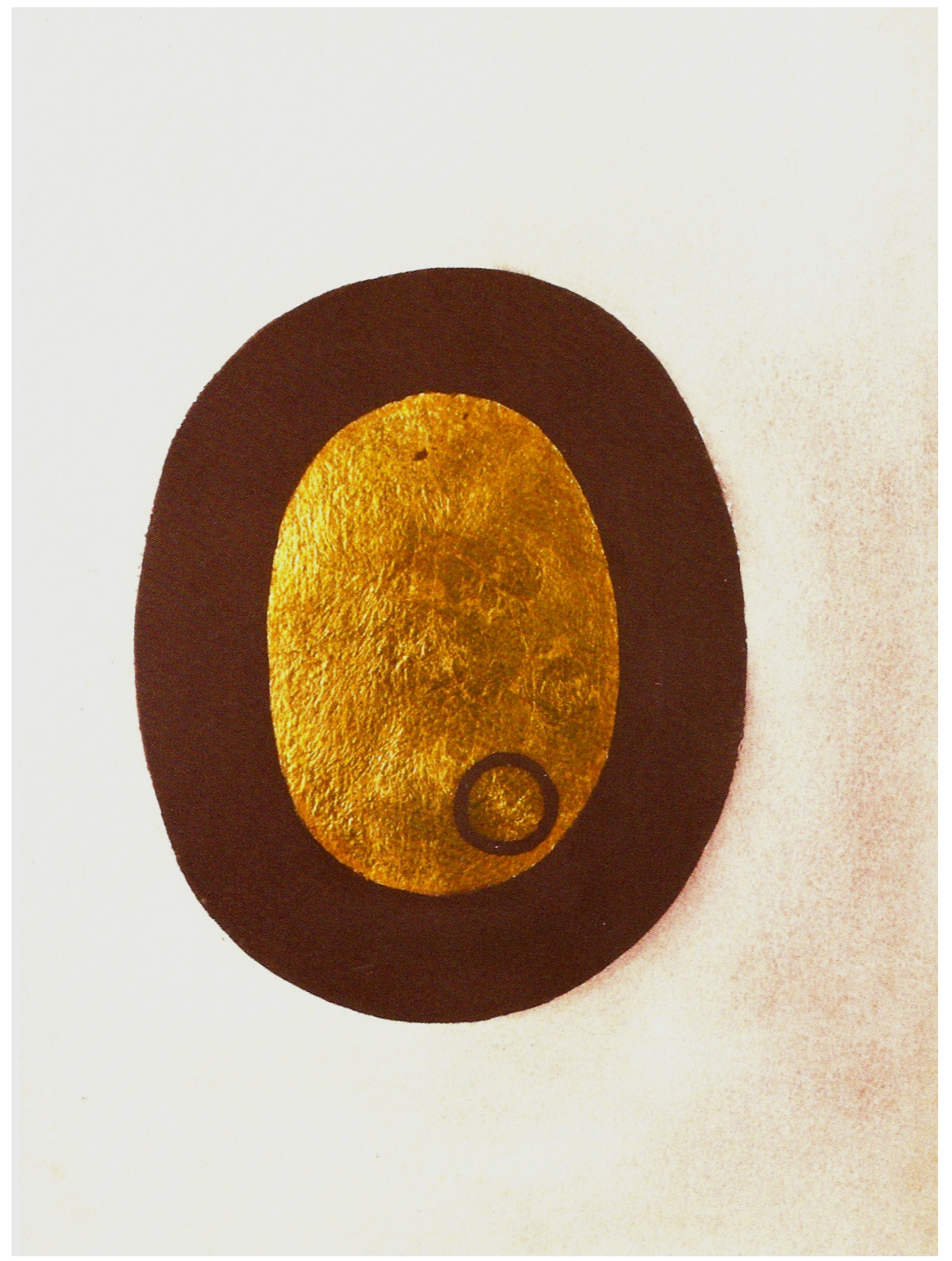

Sem Título, dec. 1980

Têmpera e folha de ouro sobre papel, $36 \times 26 \mathrm{~cm}$ 


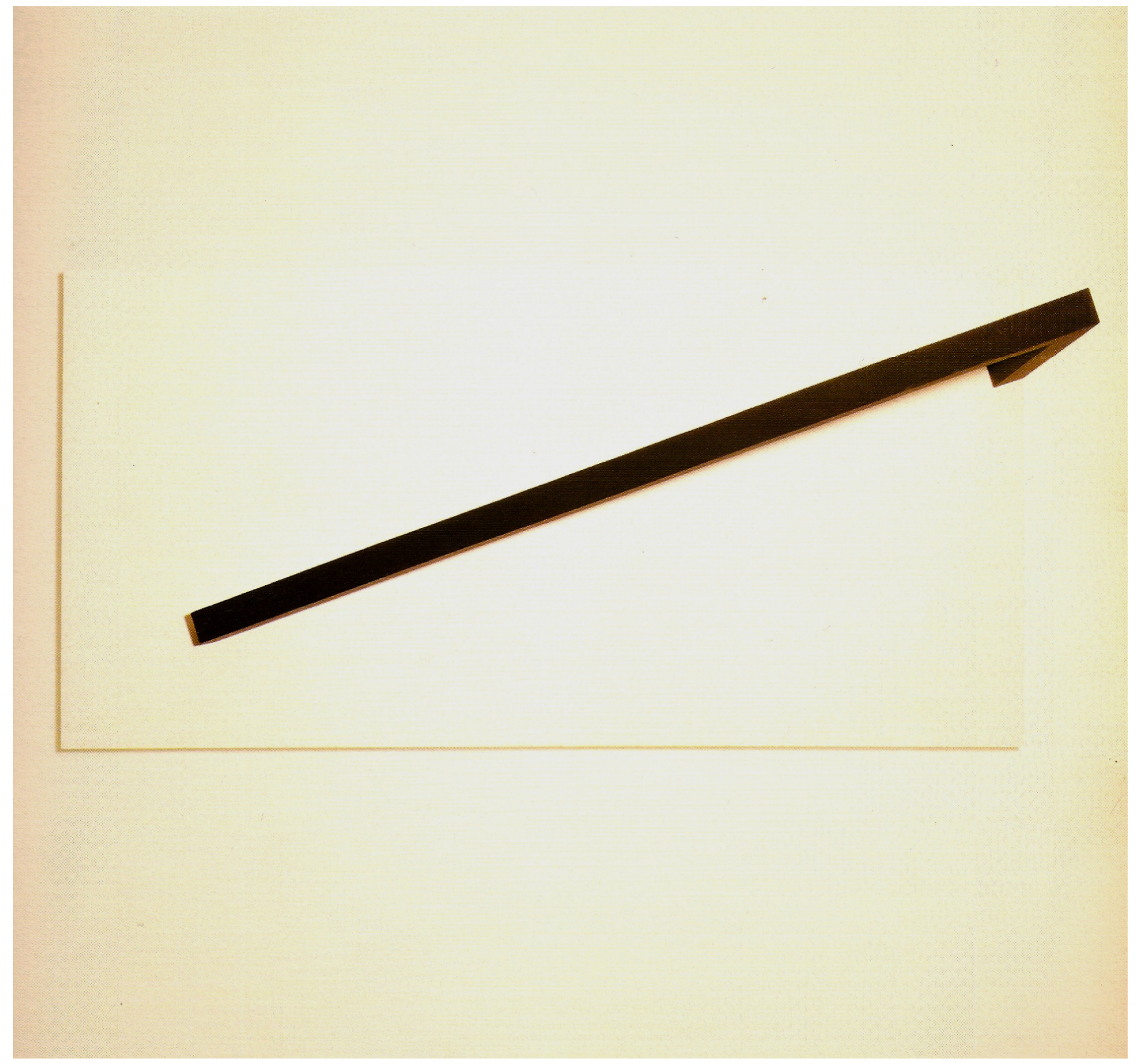

Sem Título (Sarrafo), 1987

Têmpera acrílica e gesso sobre madeira, $90 \times 180 \times 50 \mathrm{~cm}$ 


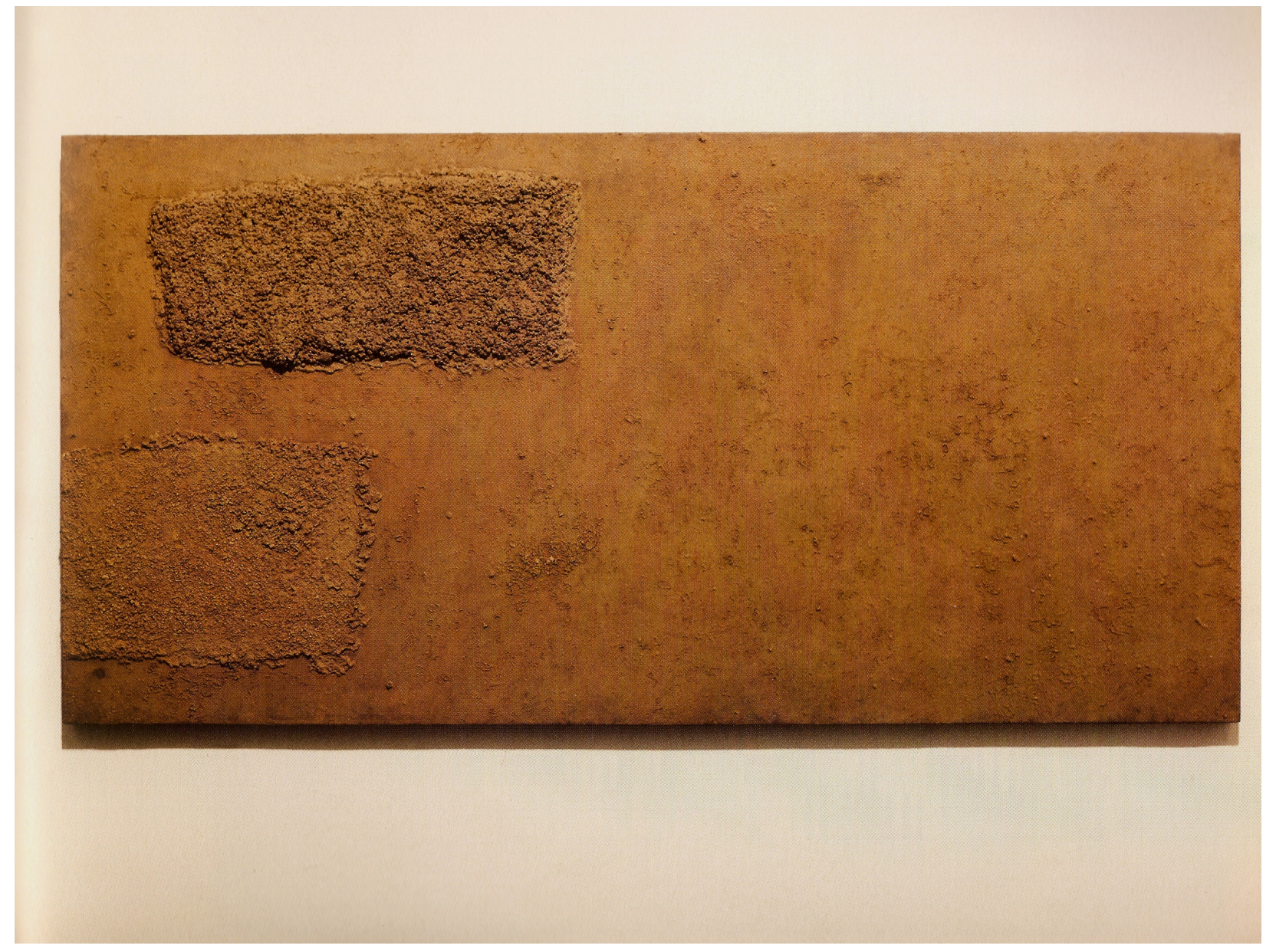

Sem Título, 1988

Pó de tijolo sobre aglomerado, $100 \times 200 \mathrm{~cm}$

Col. Museu de Arte Contemporânea Universidade de São Paulo, São Paulo 